\title{
COMPLEMENTARITY: TOWARDS ROBUST HUMAN RIGHTS GOVERNANCE IN THE NEW ZEALAND STATE SECTOR
}

By

Helen Patricia Greatrex

\author{
A thesis \\ submitted to the Victoria University of Wellington \\ in fulfilment of the requirements for the degree of \\ Doctor of Philosophy \\ in Public Policy
}

Victoria University of Wellington 


\section{ABSTRACT}

Successive governments have committed New Zealand to implementing international human rights standards domestically. In terms of practical governance, what does this mean and how might effectiveness be measured? A face-value answer can be found in domestic laws and institutions relating to human rights. However, this thesis argues that the effective implementation of ratified international human rights goes well beyond what this thesis terms the law+litigation approach (crucial though that is). By tracing developments historically, analysing the policy and governance issues, and using case studies this research shows that effective implementation is characterised by a new concept: 'complementarity'. This concept is about an increasing coherence between a number of factors affecting the state sector which impact on the fostering and delivery of human rights. These include international and domestic dimensions, law and public policy, public fairness, administrative pragmatism, and proactive and reactive approaches to implementation. Greater complementarity is shown to produce another term suggested in the thesis: robust human rights governance. The opposite - fragile human rights governance - is also explored.

As well as the complementarity model, this research also suggests there are six phases in New Zealand's human rights history. It is argued that the sixth most robust stage has been reached, but that there are elements of previous stages that are weak, developing or non-existent. Leading on from this 20 criteria to assess what effectiveness 'looks like' in relation to robust human rights governance are also developed. Although this is primarily a New Zealand study, the widespread adoption of human rights standards by many states inevitably means that the issues are relevant to other countries, even though there are always varying degrees of similarity-difference in constitutional background and developed or emerging human rights systems. This thesis shows the pathways, the mechanisms, the evolving frameworks and the approaches that would help to differentiate robust from fragile human rights governance. The tools in this research should therefore enable a more nuanced assessment of effectiveness in terms of robust human rights governance. 


\section{ACKNOWLEDGEMENTS}

I first owe a debt of gratitude to Adjunct Professor Dr Andrew Ladley of the School of Government, Victoria University, who has been the primary supervisor. I would like to acknowledge that his role included sustained discussions and input into the drafts and concepts over a 40-month period. As an international legal expert and practitioner in the broad field of human rights I could not have had a better main supervisor, and am very grateful for his assistance. I would also like to thank my co-supervisor, Dr Andrew Butler, a former law lecturer at the Law Faculty at Victoria University and currently in private practice in Wellington. His specialist knowledge of the New Zealand Bill of Rights Act 1990, which is relevant in particular to the case studies, was invaluable. Also from the School of Government I am very grateful to Dr Amanda Wolf, Director of Graduate Research Programmes, who generously became involved at various times in the research. I acknowledge, however, that this completed research is my responsibility. Dawn Yeabsley, the Coordinator at the School of Government, was also very helpful throughout the entire period of the research. Others I would like to especially thank include Susan Biggs and Denny Boothe from the New Zealand Human Rights Commission, and Corinna de Wolff, the UN librarian at Victoria University. Joris de Bres, the Race Relations Commissioner at the Commission, kindly granted permission to use the CERD Implementation Monitoring Table in Section 5.6.2. On a personal note I appreciate the great support given to me by Richard Lomas, particularly in providing a wonderful office space. Finally I would like to acknowledge the encouragement given by my family while writing the thesis - my sisters (Denise and Sharon) and especially my mother Rae. 


\section{LIST OF CONTENTS}

ABSTRACT

ACKNOWLEDGEMENTS III

LIST OF CONTENTS IV

LIST OF TABLES IX IX I

LIST OF FIGURES IX IX

LIST OF ABBREVIATIONS X X

CHAPTER 1: INTRODUCTION 1

$\begin{array}{llr}1.1 & \text { International obligation and domestic action } & 1\end{array}$

1.2 Concepts 1

1.2.1 Law + litigation 1

1.2.2 Complementarity 4

1.2.3 Other terms 9

$\begin{array}{lll}1.3 & \text { Chapter outline } & 11\end{array}$

$\begin{array}{lll}1.4 & \text { Six-phase human rights history } & 14\end{array}$

1.5 Developing criteria for effectiveness 16

$\begin{array}{lll}1.6 & \text { Methodology } & 17\end{array}$

$\begin{array}{lll}\text { 1.6.1 Research design } & 17\end{array}$

$\begin{array}{ll}\text { 1.6.2 The reflexive researcher } & 20\end{array}$

1.7 Methods $\quad 22$

1.7.1 Documentary analysis 23

$\begin{array}{lll}1.7 .2 & \text { Case studies } & 24\end{array}$

$\begin{array}{lll}1.8 & \text { Transparency and ethical considerations } & 27\end{array}$

1.9 Timeliness 28 


\section{CHAPTER 3: INTERNATIONAL FRAMEWORKS}

3.1 New Zealand at the UN: 1944-1948 63

$\begin{array}{lll}3.1 .1 & \text { Atlantic and UN Charters } & 63\end{array}$

$\begin{array}{lll}3.1 .2 & \text { UDHR, ICCPR and ICESCR }\end{array}$

$\begin{array}{llr}3.2 & \text { The international human rights system } & 69\end{array}$

3.2.1 Bi-fold organisational/legislative international framework $\quad 70$

3.2.2 Towards a tri-fold international framework: guidance level 73

$\begin{array}{ll}\text { 3.3 Regional and national human rights instruments and mechanisms } & 79\end{array}$

\begin{tabular}{l}
3.4 National Human Rights Institutions (NHRIs) \\
\hline
\end{tabular}

$\begin{array}{llr}3.5 & \text { Summary } & 83\end{array}$

$\begin{array}{ll}\text { CHAPTER 4: } & \text { STOCK-TAKE AND PLANNING }\end{array}$

4.1 Tri-fold domestic framework: organisational, legislative, policy 85

$\begin{array}{llr}4.2 & \text { Evaluation initiatives } & 87\end{array}$

4.2.1 Consistency $2000 \quad 89$

4.2.2 Re-evaluation of the Human Rights Protections in New Zealand (2000) 93

4.2.3 Compliance 2001 (and the Human Rights Amendment Act 2001) 97

4.2.4 Human Rights in New Zealand Today (2004) 98

4.2.5 Inquiry into the Role of International Human Rights in Foreign Policy (2005) 100

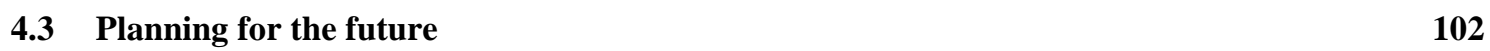
4.3.1 New Zealand Action Plan for Human
Rights (2005-2010) 
4.3.2 The Human Rights Approach (2008) 103

4.3.3 New Zealand's Universal Periodic Review (2009) 104

$\begin{array}{llr}4.4 & \text { Summary } & 105\end{array}$

CHAPTER 5: EMBEDDING A HUMAN RIGHTS APPROACH INTO THE $\begin{array}{ll}\text { STATE SECTOR } & 107\end{array}$

$\begin{array}{llr}5.1 & \text { Non-judicial approaches and early mainstreaming } & 107\end{array}$

$\begin{array}{llr}5.2 & \text { Locus of control } & 112\end{array}$

5.3 Human Rights Working Group 113

$\begin{array}{lll}\text { 5.3.1 USA inter-agency model } & 114\end{array}$

5.3.2 Joined-up government and the Coordinated State Agencies Goal 115

$\begin{array}{lll}\text { 5.3.3 Covenant obligation seminars } & 116\end{array}$

$\begin{array}{llr}5.4 & \text { Training officials } & 117\end{array}$

$\begin{array}{lll}\text { 5.4.1 HRC, Justice and MFAT } & 118\end{array}$

$\begin{array}{lll}5.4 .2 & \text { Enforcement agencies } & 119\end{array}$

$\begin{array}{lll}5.5 & \text { Cabinet vetting system } & 121\end{array}$

5.5.1 Inconsistent vetting: Treaty, bill of rights, privacy, human rights 123

\begin{tabular}{lr}
5.6 & Concluding Observations \\
\hline
\end{tabular}

$\begin{array}{lll}\text { 5.6.1 The German response: expert meetings } & 127\end{array}$

$\begin{array}{ll}\text { 5.6.2 A New Zealand model: Implementation Monitoring Table } & 128\end{array}$

$\begin{array}{llr}5.7 & \text { Human rights education } & 129\end{array}$

$\begin{array}{llr}5.8 & \text { Human rights governance level } & 134\end{array}$

5.8.1 Towards a four-fold domestic human rights framework 135

$\begin{array}{llr}5.9 & \text { Better implementation } & 135\end{array}$

$\begin{array}{llr}5.10 & \text { Summary } & 138\end{array}$

CHAPTER 6: RAISING THE STATUS OF SECOND GENERATION RIGHTS AND THIRD GENERATION (TREATY) RIGHTS 141

6.1 Second generation rights 142

6.1.1 Redressing the imbalance: New Zealand response 144

$\begin{array}{ll}\text { 6.1.2 Justiciability and the positive obligations of states } & 147\end{array}$

$\begin{array}{lll}\text { 6.1.3 Potential ideas } & 156\end{array}$ 
6.2 Human rights dimensions of the Treaty of Waitangi 160

6.2.1 How is the Treaty a human rights document? 160

$\begin{array}{ll}\text { 6.2.2 Poor statistics: continuing disparities } & 164\end{array}$

6.3 UN Declaration on the Rights of Indigenous Peoples 166

$\begin{array}{llr}6.4 & \text { Summary } & 169\end{array}$

CHAPTER 7: COMPLEMENTARITY: WHAT DOES EFFECTIVENESS LOOK LIKE? 171

$\begin{array}{llr}7.1 & \text { Clarifying robustness v fragility } & 171\end{array}$

7.2 New Zealand's status and effectiveness in robust human rights governance 174

$\begin{array}{llr}7.3 & \text { Summary } & 177\end{array}$

CHAPTER 8: CASE PRACTICE: REACTIVE AND PROACTIVE APPROACHES

$\begin{array}{llr}8.1 & \text { Baigent's case: reactive } & 180\end{array}$

$\begin{array}{lll}8.1 .1 & \text { Background } & 180\end{array}$

8.1.2 Impact on state sector: Cabinet and NZ Police response 183

$\begin{array}{lll}8.1 .3 & \text { Judicial boundaries } & 188\end{array}$

$\begin{array}{ll}\text { 8.1.4 Eventual mainstreaming } & 191\end{array}$

$\begin{array}{lll}\text { 8.1.5 Australian reaction } & 192\end{array}$

$\begin{array}{lll}8.1 .6 & \text { Summary } & 194\end{array}$

$\begin{array}{llr}\text { 8.2 Military justice system: proactive } & 194\end{array}$

$\begin{array}{lll}\text { 8.2.1 } & \text { Background } & 194\end{array}$

$\begin{array}{ll}\text { 8.2.2 Conte and Hook: constitutional unfairness } & 197\end{array}$

$\begin{array}{ll}\text { 8.2.3 Arrest, search and seizure } & 200\end{array}$

$\begin{array}{lll}8.2 .4 & \text { Judge and jury } & 201\end{array}$

8.2.5 Fair trial rights and instructing a lawyer 202

$\begin{array}{lll}\text { 8.2.6 NZDF internal review } & 204\end{array}$

$\begin{array}{lll}8.2 .7 & \text { Political support } & 205\end{array}$

$\begin{array}{lll}\text { 8.2.8 } & \text { Mainstreaming the changes } & 207\end{array}$

$\begin{array}{llr}8.3 & \text { Human rights governance level interactions } & 209\end{array}$

$\begin{array}{llr}8.4 & \text { Summary } & 215\end{array}$ 
CHAPTER 9: CONCLUDING COMMENTS

$\begin{array}{llr}9.1 & \text { General findings } & 218\end{array}$

\begin{tabular}{ll}
9.2 & Original and significant contributions \\
\hline
\end{tabular}

$\begin{array}{llr}9.3 & \text { Summary } & 222\end{array}$

REFERENCES $\quad 223$ 


\section{LIST OF TABLES}

Table 1. Six phases of New Zealand's human rights history 15

$\begin{array}{lll}\text { Table 2. } & \text { Tri-fold international human rights framework } & 78\end{array}$

$\begin{array}{llr}\text { Table 3. } & \text { Four-fold domestic human rights framework } & 88\end{array}$

Table 4. $\quad$ Major evaluation and planning initiatives/documents 1994-2009 89

Table 5. Eleven key principles of a Human Rights Approach 104

Table 6. Potential role of a Human Rights Working Group 136

Table 7. Possible policy and legislative initiatives to improve implementation 156 of second generation rights

Table 8. The Treaty and human rights $\quad 163$

Table 9. New Zealand status - effectiveness in robust human rights governance $\quad 174$

$\begin{array}{llr}\text { Table 10. } & \text { Baigent - levels of impact } & 178\end{array}$

$\begin{array}{lr}\text { Table 11. } & 190\end{array}$

Table 12. Military justice system - levels of impact 195

$\begin{array}{lll}\text { Table 13. } & \text { Mainstreaming process - military justice system }\end{array}$

\section{LIST OF FIGURES}

$\begin{array}{lr}\text { Figure 1. Regulatory pyramid } & 110\end{array}$

$\begin{array}{ll}\text { Figure 2. Human right governance level interactions } & 210\end{array}$ 


\section{LIST OF ABBREVIATIONS}

$\begin{array}{ll}\text { AFDA } & \text { Armed Forces Discipline Act } \\ \text { APF } & \text { Asia Pacific Forum } \\ \text { CAT } & \text { Convention Against Torture } \\ \text { CEDAW } & \text { Convention on the Elimination of All Forms of Discrimination Against } \\ & \text { Women } \\ \text { CERD } & \text { Convention on the Elimination of Racial Discrimination } \\ \text { CMAC } & \text { Court-Martial Appeal Court } \\ \text { CRPD } & \text { Convention on the Rights of Persons with Disabilities } \\ \text { ECOSOC } & \text { Economic and Social Council } \\ \text { EU } & \text { European Union } \\ \text { HRC } & \text { Human Rights Commission } \\ \text { HRiE } & \text { Human Rights in Education } \\ \text { HRRT } & \text { Human Rights Review Tribunal } \\ \text { ICC } & \text { International Criminal Court } \\ \text { ICCPR } & \text { International Covenant on Civil and Political Rights } \\ \text { ICESCR } & \text { International Covenant on Economic, Social and Cultural Rights } \\ \text { ICJ } & \text { International Court of Justice } \\ \text { ILO } & \text { International Labour Organisation } \\ \text { ITO } & \text { Industry Training Organisation } \\ \text { MFAT } & \text { Ministry of Foreign Affairs and Trade } \\ \text { NGO } & \text { Non-government organisation } \\ \text { NHRI } & \text { National Human Rights Institution } \\ \text { NPA } & \text { National Plan of Action } \\ \text { NZBORA } & \text { New Zealand Bill of Rights Act } \\ \text { NZDF } & \text { New Zealand Defence Force } \\ \text { OHCHR } & \text { Office of the High Commissioner of Human Rights } \\ \text { UDHR } & \text { Universal Declaration of Human Rights } \\ \text { UN } & \text { United Nations } \\ \text { UNCROC } & \text { UN Convention on the Rights of the Child } \\ \text { UNGA } & \text { UN General Assembly } \\ \text { UPR } & \text { Universal Periodic Review } \\ & \end{array}$




\section{CHAPTER 1: INTRODUCTION}

\subsection{International obligation and domestic action}

Many states have ratified international human rights treaties and thereby accepted international obligations in relation to human rights - but how have those states given effect to these obligations 'at home'? More particularly, how has New Zealand done so? It is not hard to find strong expressions of good intentions from successive New Zealand governments, such as a commitment to creating an environment in which:

... human rights considerations are at the heart of public and international policy development (Ministry of Justice, 2000a: 16).

New Zealand has an outwardly well-developed domestic human rights architecture reflected in institutions, laws and policies and an endorsement of international standards. However, the means to judge the effectiveness of the achievements to date and to highlight areas for improvement is currently lacking. This thesis suggests there are six phases in New Zealand's human rights history. This history unearths a multiplicity of changes that have affected the way the state sector works in order to produce what is widely recognised as a country that is reasonably compliant with its international human rights obligations. Twenty criteria relating to the suggested construct in the thesis of human rights governance are therefore developed to assess what effectiveness in this area 'looks like'. Developing the criteria for assessing robustness in human rights governance therefore asks: 'What is international best practice in the implementation of ratified treaty rights'? Before proceeding a number of key concepts are identified.

\subsection{Concepts}

\subsubsection{Law + litigation}

In most countries the standard prescription for human rights involves a foundation of some form of constitutional or legislative recognition of rights alongside access to the courts by complainants who feel their rights have been breached. In this research this is 
termed the law+litigation formula. It leaves effective protection to the possible coincidence of several key factors including: complainants being aware of a breach and having the capacity to litigate effectively; a functioning rule of law system; and appropriate responsiveness of government to the judgments of courts. Mostly the law+litigation formula remains the foundation of domestic protection techniques, illustrated in this country by the New Zealand Bill of Rights Act (NZBORA) 1990, the Human Rights Act 1993 and other statutes.

The law+litigation concept has been developed to succinctly capture that there is a well-functioning and strong legal approach in this area which is the 'bedrock' for human rights protection. Nothing in this thesis is intended to diminish the critical importance of the right to assert a violation of human rights through judicial processes. However important law+litigation is, experience has shown it is not enough and this is even more so in states with weak judicial systems. Chapter 7 raises the notion of 'fragile human rights states', which can have laws that actively attack human rights and at the same time have weak institutions protecting them. This research suggests that to have effective implementation of ratified treaty rights, there needs to be a complementarity of the law+litigation and policy fields in particular, and that robust human rights governance is only possible when these fields are fully aligned. Even in states that are sympathetic to the human rights endeavour, laws are better implemented when backed by sound policies. Legislation dealing with domestic violence, for instance, will be more effective when state sector agencies are jointly working on preventive measures. It is therefore more effective to reconcile the law+litigation approach with the efficiency and policy issues already part of the public management role of the state sector.

Because of this, a commitment to place 'human rights considerations at the heart of public and international policy development' (Ministry of Justice, 2000a: 16) is a very much more ambitious agenda than the law+litigation formula and it demands a different, more active, approach from government. An increasingly 'whole-ofgovernment' approach would include policy-based interventions ahead of or as well as litigation-based, and the state being proactive rather than reactive about human rights issues. These two factors - a wider approach to give effect to obligations and a more proactive role - would see a new trend by government in relation to human rights. As will be shown in Chapter 7 , these factors can also be seen as a move towards 'best 
practice' in human rights implementation.

The Baigent case study in Chapter 8 is a good example of why the law+litigation approach is only one part of a whole. When the new judicial remedy was created by this decision, there was a strong reaction from the state sector as officials tried to work out the fiscal and policy, as well as the legal, implications. Importantly too, the case tested judicial/parliamentary boundaries. In other words, at what point is a court 'making law' as opposed to 'interpreting law'? Baigent is discussed fully in Chapter 8, but there are other cases that deserve brief mention in this law+litigation section, particularly Moonen v Film \& Literature Review Board [2000] 2 NZLR 9. In this case the Court of Appeal gave clear guidance about section 5 of NZBORA concerning 'the limits that are demonstrably justified in a free and democratic society'. This was an important marking point about setting reasonable limits on the exercise of rights and freedoms. The issue in Moonen was whether the book and photographs in question could be deemed 'objectionable', and the Court took a clarifying role about the 'reasonable limits' provision. In its decision, the Court stated the test involved five aspects, but it also took ultimate responsibility for determining "whether the limitation in issue can or cannot be demonstrably justified in a free and democratic society'. ${ }^{1}$ There is obviously a short step from taking this responsibility, to issuing (if necessary) what was to become known as a 'Declaration of Inconsistency' with NZBORA, and this can be seen as a type of remedial jurisdiction. According to Butler and Butler it was in the Moonen case that the Court of Appeal 'first seriously mooted' that 'the Courts have the power' to declare inconsistencies between NZBORA and other legislation and to grant 'a formal order to that effect' (Butler and Butler, 2005: 1017).

A year after Moonen, an important feature of the Human Rights Amendment Act 2001 was that the newly created Human Rights Review Tribunal (HRRT) could now make Declarations of Inconsistency if discriminatory legislation was identified; ${ }^{2}$ this could be further appealed to the High Court, Court of Appeal and the Supreme Court. Once a declaration is made, the government is then required to publicly reassess the

1 These tests were: 'identify the objective' of the legislature in making the provision; assess the 'importance and significance of that objective'; 'reasonable' proportion must be used to statutorily achieve the objective; 'the means used must also have a rational relationship with the objective'; and 'there must be as little interference as possible with the right or freedom affected' in achieving the objective (Moonen $v$ Film \& Literature Review Board [2000] 2 NZLR 9 at 18).

2 See Section 4.2.3 for more information. 
inconsistent legislation and report to Parliament. This does not mean that the legislation is repealed, and the courts must still enforce it, but it does pressure the government to defend the need for the discriminatory enactment. So far only one declaration has been issued by the HRRT (Howard $v$ Attorney-General), and none by the courts. ${ }^{3}$ Chief Commissioner Rosslyn Noonan has noted that: 'This decision is a landmark in human rights law in that it shows how any New Zealander can challenge legislation they believe to be discriminatory and impacts upon them adversely' (HRC, 2008c: 1). Since Moonen, therefore, the courts have asserted their jurisdiction to examine legislative breaches of rights contained in NZBORA, but have not actually issued an formal declaration of inconsistency. ${ }^{4}$ It is perhaps out of sensitivity to the border that exists between policy and law that the courts have yet to issue any declarations. ${ }^{5}$

The next concept is about aligning this law+litigation field with that of public policy.

\subsubsection{Complementarity}

Using a variety of inputs from writings in both international human rights law and public policy the concept of complementarity was developed. It captures a sense of the 'progression of movement' that is evident in the historical sweep from 1945-2010 presented in this research. Many laws have been passed, policies developed, values accepted or rejected, and different ways of thinking and working have arisen, that have all led to the domestic human rights system that has emerged. This is all complementarity, and in effect the thesis is painting a 'complementarity scene'. Having reflected on the picture that developed, and taking the elements of the concept a little bit further, they bridged into the evaluation portion of the research, which leads to the

\footnotetext{
3 In Howard $v$ Attorney-General (HRRT Decision 46/06; 11 December 2006) the HRRT ruled that a section of ACC law was inconsistent with the right to freedom from discrimination set out in NZBORA (on the grounds of age). Specifically section 85 and clause 52 of the Injury Prevention Rehabilitation and Compensation Act 2001 were inconsistent with the right to freedom from discrimination affirmed by section 19 of NZBORA. The plaintiff John Howard had an arm injury and the inconsistency related to being denied simultaneously receiving both superannuation weekly compensation and vocational rehabilitation. Mr Howard wanted to continue his rehabilitation in order to be able to work in the future. Chief Commissioner Rosslyn Noonan has noted that: 'This decision is a landmark in human rights law in that it shows how any New Zealander can challenge legislation they believe to be discriminatory and impacts upon them adversely' (HRC, 2008c: 1).

4 One view on this was given by Butler and Butler who asserted that Parliament had 'effectively legitimised the notion that Courts can make declarations of inconsistency through its recognition of that form of order in the Human Rights Amendment Act 2001' (Butler and Butler, 2005: 1020).

5 See also three other cases involving the courts potentially issuing Declarations of Inconsistency: $R v$ Poumako (2000) about a home invasion; Taunoa v Attorney General (2004; 2006) about prisoner compensation vs victims' rights; and $R v$ Hansen (2005; 2007) about the misuse of drugs and the presumption of innocence.
} 
notion of effectiveness. Later at the end of the case studies (Chapter 8) the notion of a 'human rights governance level' is introduced.

Complementarity describes a process underway, and this direction can continue (or reverse). It also suggests an alignment that will point towards a 'coming together' of the law litigation and policy fields to aid the mainstreaming ${ }^{6}$ of human rights by the state sector. The international human rights system developed with the specific intention that states would themselves implement the obligations through their own systems by choice. States that signed up to the obligations promised to 'do' something. But what and how? As this thesis shows the answers developed over time. But underlying the New Zealand version at least has been the interaction between international processes and domestic constitutional, law and bureaucratic systems. This thesis suggests that this interaction can best be understood using the metaphor of 'weaving'. Weaving describes more fully what the complex, mainstreamed law+litigation/policy complementarity system would look like. Threads of human rights thinking and practice might run horizontally, vertically and perhaps diagonally throughout the social and political fabric.

For this country, as elsewhere, the mesh between international and domestic human rights implementation occurred incrementally. Today international-domestic perspectives arguably cannot be seen distinctly from each other. In the 1940s New Zealand had what in retrospect was clearly an undeveloped domestic human rights framework, matching the undeveloped international system. Over time the core international human rights conventions, international and domestic institutions, and domestic laws, policies and practices have all strengthened and become increasingly inter-linked. Thus complementarity as used in this thesis does not just describe a 'coming together' in its normal usage, but a 'weaving together'. International and domestic systems interact. A table tennis metaphor of balls being hit over the net between international and domestic players would not be quite right, although there are elements of that on occasion. A 'weave' is a better description, since the systems now interact in ways that appear to have created a new phenomenon in modern government, as well as in international law and practice.

6 The 'mainstreaming' terminology occurs across a number of disciplines but it is also used at the international human rights level. For a discussion on this see Oberleitner (2007: 103-151) who noted that a formal process was started at the time of the UN 1997 programme of reform to purposefully mainstream human rights thinking into all $\mathrm{UN}$ work and structures. 
Jumping to the present, this description of complementarity can be put into immediate context with reference to statements from the National Party-led government of New Zealand elected in 2008, making clear its ongoing commitment (and reflecting the stance of successive governments) to the implementation of international human rights standards. At the NZ Diversity Forum 09 the Minister of Justice, Simon Power, stated that after his personal involvement in the Universal Periodic Review (UPR) process in Geneva earlier in the year he was seeking input from government agencies, NGOs and others about how to further strengthen human rights implementation in New Zealand through the state sector. ${ }^{7}$ He highlighted a number of areas needing improvement that were set out in the UPR report, and he expected these to be advanced before the next reporting round in 2013. ${ }^{8}$ At the same forum Rosslyn Noonan, New Zealand's Chief Human Rights Commissioner, noted that at the present time there was:

... an unprecedented focus on human rights standards and performance [and that] the new government is open to some significant human rights initiatives (Noonan, 2009).

She believed there were several reasons for this. The presentation of New Zealand's first UPR at the Geneva in early 2009 had obviously brought this country's overall human rights situation into sharp focus, continuing the momentum from 2008 surrounding the $60^{\text {th }}$ anniversary of the Universal Declaration of Human Rights (UDHR), including a conference and other activities at the community level. ${ }^{9}$

This background about the government's commitment to the human rights area helps answer the question: "If the four-yearly UPR report gives a full account of New Zealand's compliance with international human rights obligations, then why the need for this research?' The UPR report gave a detailed account of the status of human rights

\footnotetext{
7 On 23-24 August 2009 the HRC hosted the NZ Diversity Forum 09. Part of the programme included a session on 'International Accountability for New Zealand's Human Rights and Race Relations, Human Rights Treaties and Domestic Policy and Practice'. Speakers included the Minister of Justice, the Chief Human Rights Commissioner, other Human Rights Commissioners and officials from government agencies. A question and answer time was held at the end of the session. Public comments were made by both the participants in the forum and by the audience. Occasional reference (without specific attribution) to such comments is made because the discussion suggested informal support for some of the trends I was identifying in the research.

8 The UPR report is a state-of-play report about this country's current compliance, and is a new four-yearly reporting requirement for all States Parties that was instigated by the UN Human Rights Council in 2006 (see UNGA, 2009a). The UPR report states that: 'The key priorities of the New Zealand Government as noted in the present report are: (a) Improving the economic, social and cultural well-being of people in New Zealand; (b) Reducing violence within families and its impact on women and children; (c) Improving the opportunities of young New Zealanders through the education and youth justice systems; (d) Strengthening the rights of victims of crime; (e) Improving the consultation process with civil society for future human rights reporting and follow-up recommendations; (f) Strengthening the partnership between the Government and Māori by continuing to support Māori to realise their potential and continuing the momentum on achieving fair, just and practical settlements of historical claims under the Treaty of Waitangi; and (g) The implementation of the new Convention on the Rights of Persons with Disabilities and the New Zealand Disability Strategy' (UNGA, 2009a: 22).

9 For the proceedings of this conference see Alley (2009).
} 
in this country i.e. how well New Zealand was doing in relation to prison standards or Māori child health? However, this thesis is: (a) looking at the history of the framework that has been set up; and (b) trying to develop tools (such as the six-phase history and the 20 effectiveness criteria) to see how well the specific processes and mechanisms of New Zealand's human rights framework are operating. While the UPR report may be telling the UN what they need to know about compliance, this research shows that it is not fully understand how this these processes and mechanisms really work.

It could then be asked: 'Is there any value in doing more than is already being done, given that New Zealand is considered largely human rights compliant by the UN?' This research aims to show (again using the staged history and the criteria) that there are areas where the New Zealand human rights system is strong, developing, weak or nonexistent and that there is value in strengthening all aspects of it. If the goal of the human rights system is to produce a society in which all people are treated with respect and dignity, then the better the checking mechanisms, the more cost-effective it could be for the government. For instance, a fully functioning system can potentially head off costly implications that will result from breaches of rights and this will save money in discrimination cases and avoid conflict emerging on various grounds. The two case studies - Baigent's Case and the military justice system - have been chosen to illustrate this very point. The first was expensive to the state, time-consuming and had a panic effect in the public sector; the second was done in a considered manner and before the potential breaches could be tested in the courts. The case studies are essential because the effectiveness criteria are about assessing the robustness or fragility of a whole state; the studies on the other hand illustrate both effective and non-effective implementation on a small scale and therefore act as a support to the larger thesis.

This immediate context for explaining the processes of complementarity therefore frames an important discussion about how the protection of human rights should be seen as part and parcel of the broader processes of government. Ministerial-level participation in international human rights fora shows leadership from the elected government. This is an important lever towards Chief Executives in the public sector, reflecting accountability to ministers, who in turn have further accountabilities in Parliament. Public servants respond to all this institutional leverage. Attending fora such as the UPR adds another level of responsibility: if ministers are representing New Zealand personally, their own accountability widens into the international arena. This 
ministerial commitment to these issues on the domestic stage therefore reflects the momentum for the more effective implementation of international human rights through the state sector. No doubt, the Minister's speeches would have pleased Prime Minister Peter Fraser who in the 1940s led New Zealand's active engagement with the formation of international human rights (see Chapter 3.1 for a more detailed discussion). The processes of complementarity therefore help explain how 'implementing' issues fits into the broader field of public policy as a discipline.

It is also the case that implementation is an ongoing evolving process. Having adopted the UN Convention on the Rights of the Child (UNCROC), for instance, new issues around children's rights arise over time and these are dealt with on a case by-case basis. Ongoing compliance for a country like New Zealand, which takes initial ratification very seriously and therefore lays a substantial basis at the start, is effectively about getting the margins right. UN reporting could be conceived as an ongoing test of those margins. The fact that New Zealand has ratified so many human rights treaties is in a sense a large 'intrusion' into the way the state operates, and taking these treaties into account has enormous ramifications for the government's public policy programme. This is a key reason why the system needs to be functioning optimally. Not only is the face New Zealand presents to the UN important; 'getting human rights right' at the domestic level is a major part of the everyday work of the state sector.

Complementarity is therefore an important construct in this research and part of the original conceptual work, as well as the basis for eventual findings and analytical conclusions.

Other terminology is now briefly described. The result of complementarity is effectiveness, and this is characterised by the elements in place for robust human rights governance. The criteria for effectiveness are set out in Table 9 in Section 7.2 and these broadly relate to best practice in relation to: the UN-NZ human rights relationship; the growth of the domestic human rights architecture; timely evaluation and planning initiatives; and more effective implementation of ratified rights in the state sector at a number of levels. Effectiveness is therefore about achievement as assessed against key indicators. 


\subsubsection{Other terms}

The term robust is used to mean essentially that the processes for implementation are progressively strengthening, encompassing ongoing durability and innovation, and that this continuous development will withstand changes of government and circumstance. This does not imply fixed answers, but rather adaptability and robustness of processes related to the implementation of ratified rights. Robust human rights governance is therefore characterised by the concept of complementarity leading to effectiveness. The concept of fragile, in contrast, is used with its dictionary connotations of weak, tenuous, unsound and delicate human rights protections. The spectrum here would range from states where government institutions are actively attacking human rights, to the more benign notions of states that have good intentions, but are still developing institutions and processes.

This envisages that the international and domestic processes are becoming more and more 'intermeshed', ${ }^{10}$ government responses and interventions see human rights as integral to all policy, and 'whole-of-government' responses are increasingly adopted. At its most simple, complementarity envisages that human rights have become part of public policy, and vice-versa. The notion of robust human rights governance was developed during the course of the research. Its counterpart then naturally seemed fragile human rights governance, ${ }^{11}$ and this has obvious links with the well-known concept in international policy making of 'fragile states' ${ }^{12}$

The term implementation is used often in this thesis and has been usefully described by Victor Conde from a human rights perspective:

\footnotetext{
10 This term is drawn from Christine Bell using a somewhat different context for the intermeshing of international and domestic law and actors, namely self-determination issues (Bell, 2008: 231).

11 Just prior to completing this work the concept of 'robust economic governance' was sighted (Bradford and Scott, 2009). These authors propose this analogous concept in relation to economic governance, but with particular reference to fragile states in the World Bank programme, which links to the other concept of fragile human rights governance. Their use of this robust/fragile terminology strengthens this research as the core concepts are being used in other ways independently in another international and related field.

12 A definition of this concept is given by NZ Aid: "What is meant by the term "a fragile state"? "Fragile states" is one of the many terms that have been used to describe states that are weak in their institutional capacity, control of territory and ability or willingness to provide services to their people' (accessed at nzaidtools.nzaid.govt.nz/aid-effectiveness-fragile-states/what-meant-term-fragilestate on 30 January 2010). Bradford and Scott have a similar definition: 'Fragile states are characterized by weak and unaccountable state institutions and policies that often cannot, or will not, control corruption or deliver essential services to their citizens' (Bradford and Scott, 2009: 1). The OECD also has a Development and Co-operation Directorate (DAC), which has developed 'Principles for Good International Engagement in Fragile States and Situations', otherwise known as the 'INCAF Principles' (OECD, 2007). For a further discussion on these principles see Bradford and Scott (2009: 19-20). For a general analysis about improving the status of fragile states see Department of International Development (2005).
} 
Implementation: A word used to mean the taking of steps through legislation, policy, and action to give practical effect to, and to ensure, the actual, full enjoyment of human rights by concrete measures. This word is used in the field of human rights instead of the word enforcement, which implies the use of force to correct violations. Human rights are "implemented", not enforced. Implementation is a word used to describe all methods and means used to assure the realization of human rights. For example, reporting systems, courts, special rapporteurs, and mobilization of shame (bad publicity) are all “implementation” measures (Conde, 2004: 118-119).

In the human rights field implementation is therefore about how New Zealand practically gives effect to the obligations arising from signing international human rights treaties. The term can of course be used differently across a wide number of disciplines. For instance when clarifying the relationship between human rights and public policy in the next chapter it is noted that implementation in the policy literature can be seen as the 'operationalisation' of legislation (see Section 2.2).

Finally reactive and proactive are further terms used in the research. The first approach responds (sometimes in crisis mode) to whatever emerges as a breach of rights. The second approach seeks to actively check for difficulties and inconsistencies ahead of time, which means initiating change rather than reacting to events. A reactive stance assumes that officials are not fully alert to possible problems that could arise and that systems are not geared to optimally avoid these. A proactive approach assumes a state sector that is highly geared to compliance with international obligations and that officials and systems are working to best practice.

However, other developments have helped enlarge the human rights field in New Zealand proactively, including New Zealand's role through international conventions in ending capital punishment, and in banning landmines and cluster munitions. A major proactive initiative also came to fruition in 2007 when the new UN disabilities convention emerged from some years of international negotiation in which this country had been a key player. This convention was signed by 81 countries in March 2007, and had the largest numbers of nations signing on the opening day and was negotiated in four years, the fastest time for any international instrument so far. This country was involved in its development at every stage. New Zealand was one of the first states to sign up and ratified the convention in September 2008, an Ad Hoc Committee to deal with negotiations was formed in 2001, and then in 2003 the New Zealand negotiation team was established (including disabled people and NGOs). This team worked on the first draft of the text, and in 2005 Don McKay (the UN representative) chaired the second draft committee. 
The convention marks a paradigm shift in approaching disability: instead of having a health or social welfare focus, disability is now dealt with as a human rights issue. New Zealand was already advanced in the disability field by enacting legislation such as: section 8 of the Education Act in 1989 on equal rights to primary and secondary education regardless of disability; the Disabled Persons Community Welfare Act in 1975; and the Health and Disability Commissioner Act (1994). The New Zealand Disability Strategy, led by the Office for Disability Issues established in 2001, was a useful background experience to involvement in the negotiations about the convention and this is one of the few countries in the world to have developed such as strategy. ${ }^{13}$

For the purposes of this research, the Baigent case study has been chosen as an example of a reactive approach to human rights implementation. This case is particularly helpful in highlighting the difficulties that occur when an unexpected issue arises in the state sector. The military justice system case, on the other hand, has been chosen as a proactive example because it illustrates a more streamlined process when an issue arises in a planned and considered manner. It can be noted, too, that part of the reason this was such a good proactive example was because the NZDF had increased its legal directorate from four to 28 in the space of 'just a few years' (Hansard, 2007a: 13). This allowed the NZDF to play such an active role in the development of the Armed Forces Law Reform Bill 2007.

\subsection{Chapter outline}

Chapter 1 sets out the main background information for the thesis, and in particular contains the methodology and the relationship to the literature field. Chapter 2 locates the implementation of rights in New Zealand's constitutional context and looks at the complex relationship between the international human rights system and domestic public policy. Chapter 3 contains the historical background and international context of New Zealand's early relationship with the United Nations (UN) in the 1940s through to the development of the international architecture and regional and national human rights institutions and mechanisms of today. The chapter notes the 2008 guidelines produced by the UN for states that want to have good human rights governance practices (UN, 
2008). This background therefore locates the contemporary New Zealand domestic human rights situation in its fuller international context.

Chapter 4 canvasses the several stock-takings that were carried out on the ad hoc buildup of human rights institutions, legislation and policies over the several decades since New Zealand signed the UDHR in 1948. These initiatives take account of international human rights treaty obligations and how the rights in these are best implemented and progressively realised. Some also look at where New Zealand's human rights record is meeting or surpassing international standards and areas where it is falling below. Chapter 5 builds the integration theme. It shows how human rights considerations have been integrated into the policy environment in several ways including through: nonjudicial approaches, early mainstreaming efforts, clarifying the locus of control within departments about who has oversight over human rights issues, training officials on the human rights system, examining inconsistencies in the Cabinet vetting system, and looking at new German and New Zealand models to fully implement the UN's Concluding Observations (i.e. feedback) on major treaty periodic reports. The chapter ends with Section 5.9 Better implementation. It is clarified at this point that in similar vein to other stock-taking documents - such as the Re-evaluation of Human Rights Protections in New Zealand (Ministry of Justice, 2000a) report and Human Rights in New Zealand Today (HRC, 2004a) - this thesis is highlighting possible shortcomings and raising possible ideas. That is, it is an issue-raising piece of research. The points in Section 5.9 are therefore not formal recommendations. For this reason, the parameters of the research are that no prioritising of future work to be done or costings on this are made in the thesis.

During the course of analysing the stock-take and planning material, it became clear that there are currently two important 'issues of discussion' in the human rights field in New Zealand: the status of second generation rights; and the clarification of the human rights dimensions of the Treaty of Waitangi (third generation rights). ${ }^{14}$ These are analysed in Chapter 6 because these topics flesh out the complexity of various parts of the New Zealand human rights story. How to implement second generation rights effectively has been a long-standing problem and some of the literature on ways they

\footnotetext{
14 The Treaty of Waitangi, signed in 1840, is considered a founding document for New Zealand and was made between over 500 Māori chiefs (rangitira) and the British Crown. It is considered to be a key component of New Zealand's constitutional framework. See Chapter 6.2.1 for a discussion on the Treaty as a human rights document.
} 
can be given some parity to first generation rights is examined. ${ }^{15}$ Not all rights are seen to be (or treated as) equal, and when looked at closely it becomes clear that the implementation of various generations of rights through the state sector is a highly nuanced task. This chapter also examines the Treaty of Waitangi from a rights perspective, particularly since many of the poorer statistics around the provision of second generation rights affect Māori. This area is included because of the important position of the Treaty in New Zealand's constitutional framework, which is intimately connected to the human rights framework.

Having presented and interpreted the complementarity concept in the first six chapters, an assessment is made in Chapter 7 using 20 criteria about whether New Zealand has the factors present for robust human rights governance. In examining what constitutes effectiveness in this way its opposite - fragile human rights governance - is also explained.

Having taken two selected areas that are currently important, two case studies are then presented in Chapter 8 that show differing reactive-proactive approaches with shorter or longer mainstreaming processes, depending on whether an issue has an expected or unexpected entry into the state sector. There is also a sense in which New Zealand itself is a case study as it has moved towards robust human rights governance. It was not clear at the outset of the thesis study that these approaches existed, but during the course of the research it was possible to gain a better picture of what was happening and differences in how issues are processed. These cases serve as detailed illustrations of the emerging thesis. They also weave the following different levels of response to each issue: international obligation level; domestic statute level; judicial response at domestic level; policy formulation and implementation at Cabinet and departmental levels; individuals as rights-holders level.

These two studies identify the ease and difficulty with which rights, with their genesis in the international arena, are implemented in the New Zealand state sector and then affect individual rights-holders. Any of the actors at each level - Ministers, judges, officials, individuals - can have various responses to new human rights developments that impact on New Zealand society. Using the case studies this research suggests that 
the state sector itself can react in multiple ways about a new issue including: a possible immediate reaction of alienation/panic/rejection; then acceptance and modification so the issue can be implemented and assimilated; and then ultimately the mainstreaming of the issue into the state sector. It is a measure of effectiveness, a sign of robust human rights governance, when this mainstreaming process is carried out in a considered manner and does not need to go through the first alienation/panic/rejection stage. The case studies therefore refine the evaluation of effectiveness, showing important differences along the reactive-proactive spectrum, and that analysing the mainstreaming process in these two cases may well have lessons that are applicable to other instances.

Chapters 3 to 8 therefore comprise the empirical and analytic heart of the thesis. The topical issues in Chapter 6 and the case studies in Chapter 8, in particular, serve the research by helping pin down 'where New Zealand is really at' in terms of robust human rights governance and give more colour to the "what does effectiveness look like?' question of Chapter 7 (which contains explanatory work). Having moved across the whole design framework, the conclusions of the research can then be found in Chapter 9 where the contributions to the field are re-stated.

\subsection{Six-phase human rights history}

Reflecting on this country's human rights involvement since the establishment of the UN in the mid-1940s, and on the developments above, New Zealand's history has been categorised into six phases instead of viewing the last several decades as one block. This allowed a more nuanced analysis of this time period, and resulted in the suggestion that effectiveness in complementarity will lead to robust human rights governance. Effectiveness is assessed by the position a country has reached on each stage in the model, as well as by the degree to which human rights are addressed reactively or proactively. The six phases are set out in Table 1, which also shows the relationship of the phases to the structure of this thesis. Each of the phases has key themes, and these are elaborated on throughout the research. 
Table 1. Six phases of New Zealand's human rights history

\begin{tabular}{|c|c|c|c|c|}
\hline PHASE & DESCRIPTION & $\begin{array}{l}\text { APPROX. } \\
\text { TIME-FRAME }\end{array}$ & KEY THEMES & $\begin{array}{l}\text { RELEVANT } \\
\text { CHAPTER }\end{array}$ \\
\hline ONE & $\begin{array}{l}\text { Growth of international } \\
\text { architecture - UN-NZ } \\
\text { interplay }\end{array}$ & 1940s - ongoing & $\begin{array}{l}\text { International } \\
\text { collaboration } \\
\text { Structural } \\
\text { development } \\
\text { International law- } \\
\text { making }\end{array}$ & 3 \\
\hline TWO & $\begin{array}{l}\text { Growth of domestic } \\
\text { architecture }\end{array}$ & $\begin{array}{l}\text { Late } 1970 \text { s - } \\
\text { ongoing }\end{array}$ & $\begin{array}{l}\text { Structural } \\
\text { development } \\
\text { Domestic law- } \\
\text { making }\end{array}$ & 4 \\
\hline THREE & Stock-take initiatives & $1994-2005$ & $\begin{array}{l}\text { Reviewing } \\
\text { Restructuring }\end{array}$ & 4 \\
\hline FOUR & Planning initiatives & $2005-2009$ & $\begin{array}{l}\text { Long-term } \\
\text { strategising }\end{array}$ & 4 \\
\hline FIVE & $\begin{array}{l}\text { More effective } \\
\text { implementation of } \\
\text { international human rights }\end{array}$ & $\begin{array}{l}2000- \\
\text { ongoing }\end{array}$ & $\begin{array}{l}\text { Clarification } \\
\text { Education } \\
\text { Cooperation }\end{array}$ & $5,6,8$ \\
\hline SIX & $\begin{array}{l}\text { Robust human rights } \\
\text { governance }\end{array}$ & Ongoing & $\begin{array}{l}\text { Complementarity: } \\
\text { Best practice } \\
\text { Good governance } \\
\text { Role model } \\
\text { Effectiveness } \\
\text { criteria }\end{array}$ & 7 \\
\hline
\end{tabular}

In the initial phase of the research and structuring of the thesis this table was a useful organising device, especially since it became clear that the developments have arisen like waves on a beach. The first wave came in the 1940s and continues even today, and the next major wave in the 1970s has also followed that pattern. The third major wave was the stock-take and planning initiatives that were carried out between 1994 and 2009. The last two waves - trying to implement rights more effectively and actively setting up robust human rights governance - have occurred since 2000.

Phase One marks out the early process of New Zealand helping to develop the UN organisation, and this was a time of considerable input towards that institution. 
This period in the human rights story is well-documented. ${ }^{16}$ What is not well known is the history of how that vision was implanted into New Zealand i.e. how the UDHR rights were seeded into various facets of government and civil society over the next several decades. It was during this phase that human rights in this country were largely protected domestically by common law and social services because at this time no international treaties had been ratified. ${ }^{17}$ Phase Two saw the growth of domestic human rights institutions and structures and the enactment of a steady stream of human rights legislation over the next three decades (see Table 3 in Section 4.2).

Phases Three and Four cover the stock-take and planning initiatives of the 15-year period 1994-2009, undertaken once the structural and legislative build-up had largely come to an end. The Human Rights Amendment Act 2001 was passed as a result of this stock-take. ${ }^{18}$ At this point New Zealand at last had the right structures and legislation in place, which is why it is suggested that Phase Five has now been entered. This concerns the more effective implementation of international human rights and explores other approaches e.g. policy-based. Phase Six then tackles the simple question of what effectiveness should look like and how such an understanding can be used to underpin further strengthening of robust human rights governance, with all phases subject to further strengthening. The stages are analytical, not a simple ladder of steps. Hence elements of all stages might be in progress, with varying degrees of effectiveness.

\subsection{Developing criteria for effectiveness}

The criteria for effectiveness are set out in Chapter 7. Specifically, Table 9 in Section 7.2 sets out a four-part scale for assessing New Zealand's performance in terms of robust human rights governance: strong; developing; weak; and non-existent. This scale has been used to give some nuance to otherwise bald assertions that an area is simply

\footnotetext{
16 USA human rights historian Professor Paul Lauren for instance states that: 'New Zealand played a most significant role in advancing the cause of international human rights and made a contribution that we are still experiencing today [and] exercised an influence far out of proportion to the size of the country or any previous role in international relations' (Lauren 1997: 1, 7).

17 Although the first two major covenants - the International Covenant on Civil and Political Rights (ICCPR) and the International Covenant on Economic, Social and Cultural Rights (ICESCR) - entered into force in 1976, New Zealand did not ratify both until 1978 once all domestic laws, policies and practices had been checked for compliance.

18 Another important parallel stock-take was occurring around the same time. In 2005 the New Zealand Constitutional Arrangements Committee (2005: 9) commented about their brief of reviewing this country's current arrangements that: 'It has been a scene-setting or stock-taking exercise, designed to provide a platform of information and the beginnings of a roadmap ...' Given that the constitutional framework and human rights framework are so intimately connected, it was timely that both underwent extensive reviews around the same time.
} 
'weak' or 'strong'. For instance this country's exploration of proactive vs reactive approaches to human rights issues as they arise in the state sector is growing and therefore 'developing'. There is no 'formal' inter-departmental group of officials in the state sector focusing on human rights issues, so it is fair to categorise this as 'nonexistent' ${ }^{19}$ Treaties are ratified after a careful check for compliance, so it seems reasonable to say this area is 'strong'. Other researchers may have developed a different scale, but these are put forward as sound choices using two primary influences:

- the UN Economic and Social Council has identified key features of national human rights protection systems and some of their criteria are used e.g. the rule of law, independent judiciary, incorporation of human rights standards into domestic law, good governance practices, human rights education and specialised human rights institutions (UN Economic and Social Council, 2003: 403)

- many of the ideas raised in the stock-take and planning initiatives of 1994-2009 have also been used e.g. the need for a formal inter-departmental network of officials, ${ }^{20}$ increasing the status of second generation rights, and early mainstreaming into policy making.

The criteria are therefore an amalgamation of these two influences and key issues that have arisen from this research about the more effective implementation of ratified treaty rights through the state sector.

\subsection{Methodology}

\subsubsection{Research design}

Having given some brief background information about the phased history and the evaluative criteria, this section now describes the research design. First, a useful distinction between 'methodology' and 'methods' is given by Michael Crotty. For him,

19 Section 5.3 contains a discussion on this.

20 Although there is no formal inter-departmental group of officials there have been very good instances of cross-agency coordination (a Phase Five theme) on certain projects. For instance, the Crown Law Office, Treasury, the Ministry of Defence, MFAT, the Ministry of Justice and the Parliamentary Counsel Office all helped with the NZDF review of the military justice system. 
methodology was the 'strategy, plan of action, process or design lying behind the choice and use of particular methods'. Out of this research design come the research questions, as he described methods as the techniques 'used to gather and analyse data related to some research question or hypothesis' (Crotty, 1998: 3). In simpler terms, Clough and Nutbrown saw methodology as providing 'the reasons for using a particular research recipe', while methods are 'some of the ingredients of the research' (Clough and Nutbrown, 2002: 22). They also stated that trying to pin down a definition of methodology that satisfies all researchers is extremely difficult, although for them a 'common idea' across a number of definitions is 'justification' (Clough and Nutbrown 2002: 29-30). What follows examines the broad research design and why the research is being carried out. A note is also made on 'the reflexive researcher' in this section on methodology, as some authors such as Alvesson and Skoldberg (2000) and Luttrell (2010) go so far as to call this approach to research 'reflexive methodology'.

Norman Blaikie noted that there are several core elements of a social research design including (Norman Blaikie, 2000: 43):

- topic/problem

- research questions

- research strategies

- data sources

- concepts

- data analysis. ${ }^{21}$

With this research, the core topic or problem was thinking about the comment in the $R e$ evaluation of the Human Rights Protections in New Zealand report that the government is committed to having human rights at the 'heart' of public policy (Ministry of Justice, 2000a: 16). This led to reflection on a number of issues: What does this mean - to have human rights at the heart of public policy? How is this being done at the moment? Can it be assessed? Is there any way of doing it better? What does it mean to be a fully compliant human rights state? Having thought about these issues further (and relating to the second part of the research design) two research questions started to develop:

\footnotetext{
21 Clough and Nutbrown had a similar 'critical social science enquiry' approach. Again, the research design for this thesis was similar to their model which included: 'Framing a research question; Finding out what existing answers there are to that question; Establishing what is missing from those answers; Getting information which will answer the question; Making meanings from the information which helps to answer your research question; and Presenting a report which highlights the significance of your study' (Clough and Nutbrown, 2002: 89).
} 
- How have human rights considerations been integrated into the policy environment, and does this policy area align with the law+litigation approach to achieve the complementarity of these fields?

\section{- How might effectiveness be characterised in relation to robust human rights governance?}

In order to answer the research questions an inductive research strategy was needed (the third part of the research design). It became clear that what was lacking was a framework for describing or capturing what had been found while reflecting on the core topic. This was the point where the first analytically rich framework - the more nuanced six-phased history culminating in the ideal of robust human rights governance emerged. For the first framework, which relates to the first research question, instead of looking at the period 1945-2010 as one time block, it became clear that breaking the period down into chronological phases was a useful way of demarcating this history. This became an original contribution in itself.

Once this clearer picture had been gained, it also became clear that what was lacking was a way of exploring the utility of the first framework. The time blocks or phases of the staged history then became a device through which to start to develop the second original and analytically rich framework (related to the second research question) about evaluating robust human rights governance. By this stage in the research strategy, this second framework had begun to be populated with the evaluative criteria that eventually resulted in 'Table 9: New Zealand status - effectiveness in robust human rights governance' in Chapter 7.

The research therefore started out with a curiosity about what it meant to have human rights at the 'heart' of public policy. In order to further sharpen this picture (through an iterative and inductive process), the fourth part of the research design came into effect as data sources were explored. These sources are discussed more fully in Section 1.7.1 on documentary analysis. Research was carried out first on the historical international setting of New Zealand's domestic architecture. Then a close examination was made of the stock-taking and planning initiatives that occurred between 1994 and 2009. Doing this, it became apparent that many of the recommendations of diverse reports had not been carried out, and that the specific processes and mechanisms of New Zealand's human rights architecture were not functioning as well as they could be in the state sector. Research was also carried out into the status of second and third generation 
rights in New Zealand. The combined reading in all these areas helped increase the nuanced understanding of the six historical phases, as well as in developing the evaluative criteria of Chapter 7.

Arising out of the research design came the fifth of Blaikie's core elements: concepts. Section 1.2 has already set out definitions of a number of these including complementarity, effectiveness, law+litigation, robust and fragile human rights states, proactive and reactive, and implementation. Reaching the final stage of the core elements (data analysis) enabled all the elements of the research to eventually be drawn together to fully develop the significant contributions, which are set out in the concluding chapter in Section 9.2.

As mentioned, one of the key themes of the research is implementation, and this can be carried out well (proactively) or in an ineffective way (reactively). The two case studies, which in this thesis were the final part of the research design, show clear examples of each. They help illustrate reactive and proactive examples by looking at specific instances that have recently affected the state sector. They were placed at the end of the thesis, as they do not drive the research but evolved out of it, and could only be discussed fully once the background information of the previous seven chapters had been given.

\subsubsection{The reflexive researcher}

Carrying out the research involved an iterative and reflexive approach. Part of the research process involved analysis and reflection as the research progressed. LewisBeck et al talked about reflexivity as the researcher's own relationship with the research (Lewis-Beck, 2004: 934):

\footnotetext{
It is argued that researchers are always part of the social world they study; they can never step above it in order to gain an Olympian perspective or move outside it to get a 'view from nowhere'. It is taken to follow from this that they should continually reflect on their own role in the research process.
}

It is important for researchers to have practices in place that mitigate this tendency towards bias when they go into the field. This self-awareness of potential biases across a number of areas - ideological, political, social, theoretical, ethical - can help keep the research far less subjective. The greatest danger is that the researcher will go into the field with pre-conceived ideas, looking to substantiate the opinions they have already 
formed, instead of as an open-minded inquirer. Lewis-Beck et al saw reflexivity in a positive light, as they advocated it as a 'feature of social research practice' (Lewis-Beck et al, 2004: 934). For instance, they cited that authors such as Alvesson and Skoldberg (2000) who claimed that 'through reflexivity, research can be made a transparent activity that generates genuine knowledge' (Lewis-Beck, 2004: 934). Quinn Patton more concretely provided the following guidelines about how to help ensure separation between the observer and the observed (or in this case the researcher and the research). His advice related to fieldwork with participants, but many of the points are also relevant for general social science research:

- 'Stay open. Gather a variety of information from different perspectives. Allow the design to emerge flexibly as new understandings open up new paths of inquiry.

- Use quotations: represent people in their own terms.

- Focus on pulling together a useful synthesis as [the work] draws to a close. Move from generating possibilities to verifying emergent patterns and confirming themes.

- Separate description from interpretation and judgment' (Quinn Patton, 2002: $331)$.

In this research into robust human rights governance in the New Zealand state sector, every attempt has been made to follow these guidelines. For instance, information was gathered from a wide range of perspectives: books, reports, journal articles, UN documents, and primary material (letters, memoranda, reports, briefing notes, Hansard debates and Cabinet papers). There has been extensive quotation of authors from all these sources. The first year of the research was spent largely reading, with an openness to the patterns and themes that were emerging. Description has also been separated from interpretation and judgment as follows. Chapters 1 and 2 contain detailed background and contextual information and are therefore descriptive. Chapters 3 to 6 are also largely descriptive - they show the build-up of the human rights framework in New Zealand and problems are raised, but analysis and interpretation is starting to be tentatively made. Chapter 7 about what constitutes criteria for effective human rights implementation finally contains detailed analysis and interpretations. Chapter 8 on the 
case studies is descriptive until the final two sections, which contain analysis and interpretations. Chapter 9 contains the final overall conclusions. Reflexivity was also important in carrying out the case studies in this research as will be seen in Section 1.7.2 below.

In terms of my own reflexive position, an interest in the topic of what it means to have robust human rights governance developed through my involvement in several human rights-related initiatives over the last 10 years. During 1999-2000 I helped organise international human rights seminars at Victoria University of Wellington for staff, students, NGOs and government agencies. At this stage I had an MA in political theory, and human rights theory was starting during the 1990s to become an increasingly recognised academic field overseas. In 2000-2001 I taught a 300 level course in human rights history, theory and practice to political science, law and philosophy students at Victoria. From 2003 I have been academic co-editor of Human Rights Research, a multi-disciplinary journal, also based at the university. The journal draws on contributions from fields as wide as sociology, criminology, law, political science, education, religious studies and philosophy and is based on the proceedings of an annual human rights symposium held at the university. It became clear to me as I heard and read perspectives from a number of disciplines and agencies that New Zealand's human rights framework had grown up in a rather ad hoc fashion: that there were areas of coherence but also of fragmentation. Also, looking at this country's human rights history as one large block did not seem helpful, and on reflection there were a number of stages that could be discerned. This led me to further reflect on criteria to assess robust human rights governance in the New Zealand state sector. The formation of the two research questions (the staged history and the evaluative criteria) has therefore been a direct result of these experiences.

\subsection{Methods}

As a result of the research design, a two-method approach started to develop, involving document analysis and cases studies. The two methods also relate to each other, because the case studies were underpinned by documentary analysis. 


\subsubsection{Documentary analysis}

In this research written documents (both primary and secondary material) were gathered and assessed. As noted much of the primary material was sourced from books, reports and journal articles, along with other primary material. The literature is reviewed more extensively later in this chapter in literature in Section 1.11. The research process also included gathering information under Official Information Act (OIA) 1982 requests. ${ }^{22}$

Lewis-Beck et al noted that: 'A document is any kind of physically embodied text, and a handwritten or printed text on paper, such as a letter or government report is the archetypal document ... Documents can be classified most usefully in terms of their authorship and the conditions for access to them'. They went on to categorise authorship in the 'personal sphere' or the 'public, official sphere' and access is about what conditions the document are available under: 'open', 'restricted' or 'closed': (a) open access is when they are available through 'archiving' or publication'; (b) restricted is when 'they are accessible to a wider group, but under limited conditions'; and (c) closed refers to when only a 'very limited group of people' can access them (LewisBeck et al, 2004: 282). ${ }^{23}$ In New Zealand this would equate to: (a) general publically available information; (b) publically available information released under the OIA; (c) and OIA information that is not approved for release. These authors also noted that government documents are 'the single largest type of document available to social researchers' (Lewis-Beck et al, 2004: 282).

There are, however, strengths and weaknesses in using documentary analysis as a method. In terms of strengths, Henn et al perceived it to be a 'valuable research tool' (Henn et al, 2006: 110). Because documents can contain 'direct accounts of people involved in their social situations', they also see it as important because 'there is no intermediary to influence this account, to report it, or change it. Rather such documents provide a first-hand account from the 'inside', and more than this documents potentially provide a 'rich seam' of data (Henn et al, 2006: 110). In this research, the NZ Police documents provided a first-hand account from inside the state sector when the Baigent

\footnotetext{
22 Helpful material came from the HRC, the Ministry of Justice, the NZDF, MFAT, the State Services Commission, the NZ Police, the Department of Corrections, the Immigration Service of the Department of Labour, and the reference staff of two libraries (the Victoria University Library UN Room and the Law Library).

23 Henn et al had a similar classification: 'public and private documents; primary and secondary documents; and solicited and unsolicited documents' (Henn et al, 2009: 113-114).
} 
decision was first made, and in general provide a rich seam of data that has previously been unpublished.

Regarding weaknesses, the material may not be genuine, or accurate, or represent this type of document well, or have its meaning readily identified. Lewis-Beck et al therefore set out four criteria for the 'effective use of documents': 'authenticity, credibility, representativeness and meaning' (Lewis-Beck, 2004: 283). ${ }^{24}$ Authenticity relates to having a verifiable original or a copy obtained from a reliable source, as well as 'soundness' that the authorship is correct. Credibility relates to such factors as the accuracy of the document, and whether it is presenting 'information' or persuasive argument. The documents must also be 'representative' of their type and have been kept original from their date of writing, compared with an edited version of a report that gets changed over time and the original report is no longer stored (Lewis-Beck, 2004: 283).

The document can also be assessed in terms of meaning: 'literal and interpretive'. Literal means whether the document can actually be read or is the text too faded? Interpretation, on the other hand, is about what the researcher brings to the text in their own unique way of finding meaning from it (Lewis-Beck, 2004: 284); this links to the concept of 'reflexivity' discussed in the next section. It is obviously necessary with documentary analysis for the researcher to carefully check documents before including them in the research. In this research the Rt Hon Doug Graham, for instance, is quoted from material such as briefing notes and memoranda. Having been sourced from OIA material, the documents were verified as authentic, and their type and context is clearly set out in the thesis before the author is quoted. This technique was used for each primary document used in the research, most notably in the case studies where most of this material can be found.

\subsubsection{Case studies}

Case studies have a particular function in social science research. Mabry noted they 'provide deep understanding about specific instances' (Mabry, 2008: 216). Importantly for the doctoral research, they add to 'knowledge and understanding' because they 'contribute substantively to social science by offering intense focus on cases of interest,

24 Henn et al also made a similar point that potential weaknesses of documentary analysis are whether the text is accurate and representative (Henn et al, 2009: 121). 
their contexts, and their complexity' (Mabry, 2008: 216). Stake highlighted the difference between an 'intrinsic case study' and an 'instrumental case study': the first being undertaken because 'the case itself is of interest'; the second because 'a particular case is examined to provide insight into an issue or to redraw a generalization' (Stake, 2005: 445). He also noted there can be single cases or more than one study, the latter sometimes carried out for comparative purposes (Stake, 2005: 445-446, 457). Cases also need to have a 'conceptual structure', and this 'conceptualizing' helps the study confirm that: 'There is [actually] something to be described and interpreted' (Stake, 2005: 458, 459).

Cases are first identified, and this will depend on factors such as 'the researcher's interest' and their 'industry in identifying a case informative enough to be worth studying' (Mabry, 2008: 217). As already mentioned in the reflexivity section above, the problem of subjective bias is present in any research. However, Mabry said that in case studies 'each reader and each researcher will construct a unique personal understandings of a case' (Mabry, 2008: 221). As a safeguard, it is therefore imperative that: 'Rather than searching for data to confirm or disconfirm an a priori theory or hypothesis' researchers should 'notice opportunities and to follow data wherever they lead' (Mabry, 2008: 218). Openness was also seen by Mabry to be key to the research (Mabry, 2008: 224):

\footnotetext{
With deep understanding of a case as the prime goal of case study, an attitude of openness may be the most fortuitous item in a case study researcher's toolkit. ... Curiosity to know more and to understand better encourages delving deeply into the meaning of a case. Link by link, case by case, construction of meaning by the researcher, by the reader, and by the research community is how case study contributes to social science and to society.
}

Once the data is collected (and aware of their own bias) the researcher can then embark on 'thematic analysis', which includes identifying 'emerging patterns and categories from iterative reviews of the dataset' (Mabry 2008: 218). It is out of this process that findings develop. Once the findings are clear, narrative reporting can begin: 'the final step in a long analytic process' (Mabry 2008: 219). Mabry suggested that: 'A case study researcher can promote understanding by collecting and organizing information, focusing attention on meaningful aspects, and providing an external analytical perspective that may be helpful even to insiders intimately familiar with the case' (Mabry 2008: 220). 
The two case studies in this research were chosen because they illustrate not only the different impact of reactive and proactive approaches for the state sector, but also complementarity in the marriage of the law+litigation and policy fields to address the breach (or potential breach) raised in each instance. In the first study (Baigent's Case), existing law was further amplified by the court with the granting of damages, and for fiscal reasons many departments had to check their policies and practices to ensure the breach did not happen again. In the second study (the military justice system), many years of legal and policy analysis resulted in both an amendment Act and extensive restructuring of the organisation, policies and practices of that system.

This correlates with Mabry's 'deep understanding about specific instances'. The studies were both intrinsic (in that the cases were of interest themselves) and instrumental (because they provided more insight into the issues just mentioned). A comparison between the two cases was chosen, primarily because they would illustrate both (a) the proactive and reactive distinction; and (b) differences in mainstreaming when an issue is expected or unexpected in the state sector. A conceptual structure was imposed on each case so that it was examined for its impact at several levels - Cabinet, judicial, legislative, departmental, the individual - and this was another way of making comparisons. Also, each case has a similar overall structure in that background information is given first, the specifics of the case are set out, and then the mainstreaming tables (11 and 13) are developed.

As a safeguard against researcher bias, the case studies were entered into with an open approach, so that no a priori theory or hypothesis was searched for. Rather, it was through gathering material about each of the cases that the reactive and proactive dimensions, and the mainstreaming differences, became evident. This is why the case studies are given at the end of the research: the thesis is not 'based' on the cases; rather, the studies unfolded' out of the research. Mabry's 'thematic analysis' started to develop during the reading stage, where 'emerging patterns and categories' became evident and then findings were made. Stake had also made the connection between case study and public policy: that the former can be 'a disciplined force in setting public policy' (Stake, 2008: 460). In these studies, the connection between case study and public policy is strong because both Baigent and the military justice system studies show how changes in public policy occurred as a result of each case. 


\subsection{Transparency and ethical considerations}

Clough and Nutbrown had commented that transparency is important in the research process (Clough and Nutbrown, 2002: 29). The combined effect of many of the issues raised in the sections above results in greater transparency, that is, results in best thesis practice. For instance, as noted above Alvesson and Skoldberg claimed that reflexivity encourages transparency. Lewis-Beck et al above had noted that careful document analysis also requires the researcher to be sure of the authenticity and credibility of the data being analysed. Mabry had also suggested that openness is required for data collection and data analysis (Mabry, 2008: 218). The advice from Quinn Patton about keeping a separation between the researcher and the research is also relevant: to gather material from many perspectives and be open to new paths emerging as the research unfolds; to use quotations so that people are represented in their own terms; and to separate description from judgment. As noted in the previous two sections on documentary analysis and case studies this research was carried out with these safeguards in mind.

A statement is now given about ethical considerations. During the initial scoping and enrolment stage, the issue of whether the research needed VUW Human Ethics Committee approval was discussed with my supervisors. It was felt that because there was no intention to adopt a methodology involving gathering information by interviews or by any other 'research of human subjects' under the VUW Human Ethics Policy (Research Policy Group, 2010), the research was not being carried out in any manner contrary to the university's ethical standards. The research was seen to be covered especially by Section 4.4(b) of the guidelines about matters that do not need approval, in particular Section 4.4(b)(iv) that information obtained from 'existing publically available documents or information' did not need approval. My understanding has been that information in the public domain includes comments and discussions arising in a conference presentation or public forum question and answer sessions.

An important aspect of the research process was Official Information Act (OIA) 1982 requests for publically available material (Section 6 of the VUW Human Ethics Policy mentions OIA information in more detail). All use of such material, including emails, is 
therefore referenced to its source and relates to official information. I also acknowledge the value of impromptu discussions with a range of people on the research issues in the course of attending conferences and meetings. One some occasions, for instance, at breaks people suggested references that might be helpful for the research. I also attended several public conferences, forums and seminars where there were open panel discussions and questions from the audience. One particularly relevant forum (the $N Z$ Diversity Forum 09) is mentioned several times throughout the thesis. In a few examples, points are illustrated by reference to (anonymised) comments that were made publicly in the course of this forum. These comments can be found in Sections 5.2, 5.3,

5.5.1 and 5.6.

\subsection{Timeliness}

A New Zealand study in this area is important because of this country's high profile international positioning in the post-war phase and because successive governments continue to be committed to creating a world-leading human rights environment.

Across the period of this research (2007-2010) there has been a noticeable increase in government focus on international human rights by both Labour and National-led government administrations and three examples illustrate this. First, as mentioned, New Zealand was instrumental in developing the UN Convention on the Rights of Persons with Disabilities and ratified this in 2008, and secondly New Zealand presented its first UPR report to the UN in Geneva in May 2009. Thirdly, the human rights evaluation ${ }^{25}$ and planning ${ }^{26}$ initiatives that were carried out in New Zealand in the 15-year period between 1994 and 2009 are coming to an end. Attention is now turning to the issues that

\footnotetext{
25 Briefly the evaluation initiatives were: (1) The HRC's Consistency 2000 project, which started in 1994 and was an examination of all legislation, policies and practices to check consistency with the anti-discrimination provisions of the Human Rights Act 1993 (HRC 1998); (2) Compliance 2001, an audit carried out on the same area by the Ministry of Justice in 2001; (3) The Re-evaluation of the Human Rights Protections in New Zealand independent ministerial report, commissioned by then Associate Minister of Justice and Attorney-General Margaret Wilson because New Zealand's human rights laws and institutions had grown organically and it was seen as a timely point to take stock and review these in a systematic way (Ministry of Justice, 2000a); (4) Four years later the HRC published Human Rights in New Zealand Today as the first comprehensive status report on human rights in this country and flagged what work needed to be done in the future (HRC, 2004a); (5) This further evaluation report had a focus away from the domestic arena. Inquiry into the Role of International Human Rights in Foreign Policy, carried out by the Foreign Affairs, Defence and Trade Committee, looks at human rights from another angle and has a good section on the human rights training available at the time (NZ House of Representatives, 2005).

26 The most important planning document is the New Zealand Action Plan for Human Rights 2005-2010 which contained goals for more effective human rights implementation during that time period. As this is coming to an end a version for the years 2011-2016 is being drafted by the HRC (HRC, 2005a). Another document which highlighted areas that need improving is New Zealand's UPR report (UNGA, 2009a).
} 
comprise chapters in this research - embedding a human rights approach into the state sector, raising the status of second generation rights and more clearly understanding the human rights implications of the Treaty, and understanding reactive and proactive approaches. These developments make this research timely and current not only in charting developments, but in contributing (modestly) to them. The military justice system case study in Chapter 8 also illustrates the currency of this research. This issue had a long incubation through various phases: research into the problem starting in 1996; slow restructuring of the military disciplinary system after an internal NZDF review in 2001; eventual development of amending legislation enacted in 2007; and judges sworn in on 10 July 2009 in readiness for the new military judicial system. To be carrying out this research at the tail end of this 13-year history means that a more complete picture can be viewed as the process has come full cycle.

It has therefore been opportune to carry out this study at the end of a period of assessment, restructuring and planning and at the beginning of a phase of renewed commitment to the more effective implementation of ratified international human rights treaties.

\subsection{Generations of rights}

It is useful briefly at the beginning of this research to begin with the concept of 'generations' of rights. As the word itself implies, the suggestion is of progressive 'generational' development, covering evolving concepts of rights and the correlative differences in the responsibilities of states and citizens. Although this thesis mainly focuses on the first three generations of rights, for the purposes of seeing them in context it is useful to consider five possible generations:

- First generation: These are classic civil and political rights associated with liberal democracies, such as the right to life and freedom of speech, assembly and religion. They protect the individual from abuse by the state and are found in Articles 3-21 of the UDHR and in the whole of the ICCPR. In general terms, these 'negative' rights envisage limits to state action i.e. governments and legislatures 'staying out of' interference with basic rights. Examples include not passing laws or adopting practices which interfere with freedom of worship, or 
political expression, or which discriminate against people on various grounds.

- Second generation: These focus on economic, social and cultural issues, such as the right to adequate medical care or to an education. They ensure citizens within states have equal treatment and are found in Articles 22-27 of the UDHR and in the whole of the ICESCR. Again, in general terms, the responsibilities of the state are more active in that they envisage the state at least creating the conditions for the progressive development of these 'positive' rights, and perhaps even actually funding and supplying them. ${ }^{27}$

- Third generation: These are also known as group, collective or solidarity rights - such as the rights of indigenous peoples to protect their culture or to selfdetermination. The role of the state has aspects of both limiting power (i.e. not interfering with these rights) and proactive duties to foster the implementation of such rights. ${ }^{28}$

- Fourth generation: These are essentially environmental or ecological rights they focus on the responsibility of humans to protect the environment and again have both limiting and positive obligations on the role of the state. ${ }^{29}$

- Fifth generation: These are still very much in development and flow from all of the above. They relate broadly to the rights of unborn or future generations to inherit a sustainably managed earth. Again, the responsibilities of the state and citizens are both positive and negative (in the sense of refraining from damage). ${ }^{30}$

It will be clear that first generation rights are the most commonly accepted, closely followed by second generation rights. There is abundant commentary on these rights in

27 Liebenberg (2006: 109-113) examined the positive obligations of states, and Section 6.1.2 of this research also contains a discussion on this topic.

28 See for instance Saito (1996: 395-397) on the development of third generation rights in USA law, and for a brief discussion of these rights generally see Conde (2004: 258-259).

29 See Shelton (1991: 103) on human rights and environment rights, and Boyle and Anderson (1996) on human rights approaches to environmental protection. The latter authors made the comment, however, that these are areas of competing rights: 'Like human rights, environmental law houses a hidden imperial ambition; both potentially touch upon all spheres of human activity, and claim to override or trump other considerations' (Boyle and Anderson 1996: 1).

30 Weiss (1990: 198) for instance discussed the rights and obligations of the current generation to future generations in relation to the environment. 
standard human rights texts. ${ }^{31}$ Third generation rights is a newer term, with some reasonably-widely acknowledged aspects (including developments in relation to the UN Declaration on the Rights of Indigenous Peoples). Fourth and fifth generation rights are at even earlier stages of development and are not commonly accepted. However, they have been cited for instance by Marshall who also noted that: 'the categories of second-, third-, and further-generation rights have been the source of considerable controversy' (Marshall, 2002: 31-32).

One reason for the emphasis on second generation rights in this thesis is that HRC statements show there are many areas where this country is falling below international standards related to the lack of provision of such rights. ${ }^{32}$ Because these rights by definition envisage a more active role of the state, it is therefore helpful to use them to explore the concept of implementation. Chapter 3 shows how these rights were central to the concerns of the New Zealand delegation led by Prime Minister Peter Fraser to the UN in the mid-1940s. As will also be seen in that chapter, the importance of these second generation rights in New Zealand's human rights history actually started in the late $19^{\text {th }}$ century. The first part of Chapter 6 focuses solely on the issue of raising their status, while the second part on third generation Treaty rights also examines this issue because of the ongoing poor statistics for Māori in this area. Implementing such rights thus requires particularly proactive engagement by all aspects of government.

\subsection{Relationship to the field}

This thesis draws on the fields of international human rights (including international human rights law) and public policy. This research is building on what others are doing in these areas by taking a New Zealand approach that looks at this country's international and domestic engagement with human rights over the last several decades, albeit in outline, and picking up key themes. The work of authors from these fields is discussed throughout. This section briefly illustrates how this thesis locates itself in

\footnotetext{
31 See for instance Donnelly (2003: 27-30), Steiner, Alston and Goodman (2008: Chapters 3 and 4) and Vasak (1982: 48-53). 32 For instance the HRC report Human Rights in New Zealand Today cited the following pressing issues: "the poverty and abuse experienced by a significant number of children and young people; the pervasive barriers that prevent disabled people from fully participating in society; the vulnerability to abuse of those in detention and institutional care; impact of poverty on the realisation of the most basic human rights; the entrenched economic and social inequalities that continue to divide Māori and Pacific people from other New Zealanders; the challenge of the place of the Treaty of Waitangi now and in the future' (HRC, 2004a: 379).
} 
these fields and how it adds to them. International human rights law and public policy are looked at in order to develop the construct of complementarity, which for reasons that become apparent needs to draw on both.

The first broad field of international human rights is well occupied by many authors who show how the human rights system fits into the general international law framework. ${ }^{33}$ A good example is a major text authored by three New York legal academics (Steiner, Alston and Goodman, 2008) which backgrounded many of the primary themes in the area such as human rights issues and discourse, types of generational rights, the human rights organisations (UN and NGOs), states as protectors and enforcers of human rights, and current topics (such as Truth Commissions, the growth of self-determination movements, development and globalisation). ${ }^{34}$ These authors stated that the international 'human rights movement now forms an indelible part of our legal, political and moral landscape' and further suggested that the impact of this movement is now so strong that it affects many fields. ${ }^{35}$ They used the term 'movement'; part of this thesis will be that the human rights endeavour is so large globally and so pervasive in the government policy programme that it can possibly be considered a set of underpinning principles in the state sector. ${ }^{36}$

The human rights endeavour is not only pervasive in the policy programmes of governments; it also has as one of its major effects the erosion of the doctrine of state sovereignty. International law specialist Malcolm Shaw noted that the basic principle of domestic jurisdiction has over time: 'been subject to a process of reinterpretation in the

\footnotetext{
33 See for instance Ian Brownlie (2008, Chapter 25); Antonio Cassese (2005, Chapter 19); Malcolm Evans (2006, Chapter 25); and John O'Brien (2001, Chapters 15 and 16).

34 Steiner, Goldman and Alston have also written widely in other texts on this area. For instance see: on the relationship of human rights to democracy and their international protection (Steiner, 1999, 2006); a critical appraisal of the UN system (Alston and Megret, 2009); and the role of non-state actors (Alston, 2005). Professor Philip Alston has been a practitioner as well as an academic in the field, having been the UN Special Rapporteur on extrajudicial summary or arbitrary executions since 2004 and he has also helped the UN General Assembly with the reform of the UN human rights treaty monitoring system.

35 These fields include: ‘... law, government, international relations and institutions, moral theory, public health, world financial institutions, ecology, economic development, ethnic conflict, religion, education, cultural studies and anthropology’ (Steiner, Alston and Goodman, 2008: v).

36 While the two major parties in New Zealand, for instance, have tended to accept this human rights endeavour, it is not necessarily uncontested in other liberal democracies. The Conservatives in the UK had canvassed the idea of repealing the Human Rights Act (HRA) 1998 if they won the 2010 election. However, one problem with this stance is that it would require withdrawing from the European Convention on Human Rights, as not doing so would leave UK citizens able to take claims to Strasbourg-based judges. As it is unlikely that the UK would withdraw from this convention, the repeal is unlikely to happen. Labour, on the other hand, had gone in a seeming opposite direction by developing a discussion paper in 2009 on a bill of rights which would extend the protection of economic and social rights. For a discussion on these Conservative and Labour approaches to human rights see Conor Gearty (2010: 27-29).
} 
human rights field' (Shaw, 2003: 254). However, he also cited another well-known principle in international law (the exhaustion of domestic remedies rule) where states are given the chance to sort out their own problems before international intervention occurs. ${ }^{37}$ An area of 'blended sovereignty' has therefore emerged since World War II where the international and national arenas share mutual responsibility for ensuring human rights protection. ${ }^{38}$ However, given the increase in globalisation generally, it is not only the human rights area which is wearing down the traditional notion of state sovereignty. Countries come under international law across a large range of issues (such as postal regulations, international monetary policy and maritime law), so the human rights field is only one part of the eroding aspect of internationalism on a state's power. ${ }^{39}$ The sovereignty issue is therefore a very important element of another type of complementarity: international-domestic.

In his analysis of the issue of sovereignty at the beginning of the $21^{\text {st }}$ century New Zealand Supreme Court and International Court of Justice (ICJ) Judge Sir Ken Keith asked: 'Can we sensibly think of states being sovereign in relation to one another? Does not the standard meaning of sovereignty incorporate within it supremacy, of ruling over or from above? How does that fit with the coexistence and cooperation of 191 or more states in the world community?' (Keith, 2004: 595). He noted that the UN Charter: 'does not include State sovereignty within its purposes and principles. Rather its first principle is that the organisation is based on the principle of sovereign equality of all its members' (Keith, 2004: 596), and goes on to describe the elements of this equality found in UN General Assembly Resolution 2625 (XXV). ${ }^{40}$ He then reflected: 'That text incorporates real tensions. It is a text prepared through a testing political-legal diplomatic process which required wording acceptable to all United Nations members' (Keith, 2004: 596). Although this is not an easy ongoing issue in international law, it

\footnotetext{
37 This rule also relates to the Optional Protocol route discussed more fully in Section 2.3. An individual is only able to make a complaint to a UN treaty body committee using this mechanism after they have tried to have the matter dealt with at the national level. See UN General Comment No. 9 on the exhaustion of domestic remedies (UNCESCR 1998).

38 See, however, Henkin (1995: 31) who suggested deconstructing the concept of state sovereignty altogether. He did not believe it was a useful concept and felt that it was 'a mistake built upon mistakes', which in his view had caused it to be 'a barrier to international governance, to the growth of international law, and to the realization of human values'.

39 For a discussion on the impact of an increasingly globalised economy on state sovereignty see Kobin (1997).

40 The elements include: '(a) States are juridically equal; (b) Each State enjoys the rights inherent in full sovereignty; (c) Each State has the duty to respect the personality of other States; (d) The territorial integrity and political independence of the State are inviolable; (e) Each State has the right freely to choose and develop its political, social, economic and cultural systems; (f) Each State has the duty to comply fully and in good faith with its international obligations and to live in peace with other states' (Keith, 2004: 596).
} 
can be said that the international human rights framework has been one of the factors causing a major reconceptualisation of the nature of the state in the international and domestic orders, and this thesis is a sub-set of that.

The above authors gave a broad brushstroke about international human rights and issues of state sovereignty generally, but this research also relates to the sub-field of the domestic transfer of these rights. That is, this thesis is looking at the more effective implementation of ratified treaty rights that enter New Zealand's legal/policy framework via obligations set out in the covenants that have been signed. This look at the domestic transfer of international human rights leads to a public policy connection because laws in New Zealand are of course underpinned by government policies.

There are many aspects to this transfer including the way states are affected by and monitored in this area (see Clark, 2000), enforcing these rights through national courts (see Francioni and Conforti, 1997), and the problems of aligning international and domestic law (see Kirby, 1997). These authors showed that the transfer of international rights into domestic law is not straightforward: it is definitely pervasive in any national legal system, it can be taken more or less seriously by the judiciary in each state, and tensions can result at the national court level from the increasing interpretive use of international treaties in domestic decision-making. Roger Clark, for instance, showed that international law has multiple effects on the state. ${ }^{41}$ This is a good point because, like a domino effect, once a country ratifies a new human rights treaty the impact on the domestic sphere is manifold and far-reaching at every level. This is an area in which this thesis adds to the field, by using the Baigent and military justice system case studies to illustrate the domino-like penetration of ICCPR obligations into the New Zealand state sector.

The issue of enforcing rights in national courts is explored by Italian legal academics Francesco Francioni and Benedetto Conforti. They looked at what is happening in a number of countries, and the peculiarities of the legal system in each of these states mean they face different problems in implementing international obligations through the courts. This text assessed the common obstacles and then suggests different judicial

41 Roger Clark, a New Zealander based at Rutgers University, is a leading writer in the field of international law and criminal law. He stated that in signing multilateral human rights treaties countries come under some sort of supervisory or monitoring system, which will cause changes in administrative practice as they try to comply with obligations. The legal systems of states are also expected to take into account major treaties in domestic law-making (Clark, 2000: 185-186). 
models that could iron out these issues. They looked at the jurisprudence of international human rights enforcement through various national courts and noted the several methods available to them to effectively enforce these rights. ${ }^{42}$ However, despite all these options these authors had grave concerns about the obstacles to effective implementation that can occur at the national level, such as the inefficiency of the judicial machinery and the old-fashioned attitudes of some judges in certain countries to human rights obligations (Francioni and Conforti, 1997: 33-34). In their view: 'The hiatus between the international recognition of rights and their actual implementation by domestic courts, and by public organs generally, is still one of the most disturbing aspects of the international effort to ensure respect for human dignity' (Francioni and Conforti, 1997: 15). Their findings confirm the view put forward earlier that the law +litigation formula is never enough i.e. that there is obviously no simple equation of 'treaty ratification = improved human rights'. The complementarity model is suggested in this research which links the legal and policy fields to more effectively implement ratified rights.

Justice Michael Kirby is another author who had explored international-domestic law alignment. ${ }^{43}$ In a penetrating article on the domestic implementation of international human rights he looked at the ever-increasing reconciliation between international and domestic law and the challenges this places the courts under. He discussed the line between providing robust enough recognition of ratified treaty rights in domestic law and what he saw was the unwise use of international treaties to affect domestic decision-making. Justice Kirby believed that in Australia: 'litigants and lawyers are turning to international law in the quest for a peg on which to hang arguments designed to persuade Australian courts that part of international jurisprudence has been, or should be, incorporated by judicial decision' (Kirby, 1997: 2). He was also concerned that laypeople 'commonly expect international law to override domestic law and to be capable of doing more than ordinarily it can' (Kirby, 1997: 5). The first case study on

\footnotetext{
42 These methods include: ‘... constitutional provisions or principles of national jurisprudence requiring the application of customary international law in domestic litigations; the technique of incorporation or direct application of international treaties; the various interpretative devices, such as the presumption of conformity of national law with treaties in force, and sometimes even the supremacy of international law over inconsistent domestic law' (Francioni and Conforti, 1997: 17). The Office of the High Commissioner for Human Rights also provided a manual to assist judges in interpreting international human rights law (OHCHR, 2003).

43 Justice Kirby is a former Australian High Court judge and chairperson of the Australian Law Reform Commission, with considerable experience in the international human rights field, for example as Special Rapporteur for Human Rights in Cambodia.
} 
Baigent will show that international law such as the ICCPR can be used as a lever to alter domestic law on behalf of individuals.

A further sub-field is that of human rights history and theory and there is a large literature in this area. This sub-field is mentioned briefly just to note the historical and theoretical underpinnings of the modern post-World War II human rights system. Leading authors in the area are human rights historian Paul Lauren (1997, 1998, 2003) and human rights theorist Jack Donnelly $(2003,2007) .{ }^{44}$ Lauren's work showed, for example, that concerns about human rights and how to put in place societal rules around them is not a recent phenomenon. He started by looking at the human rights principles underlying all the major religions of the world, thus tracing the human rights tradition back thousands of years, and examined the views of a number of philosophers including non-Western cultures (Lauren, 2003: 5-10, 10-21). It is from this very long historical perspective that he then discussed the $20^{\text {th }}$ century human rights movement, particularly the UN Charter and the UDHR. He also analysed current issues such as globalisation, non-state actors and terrorism, and these effectively international public policy issues are ongoing. ${ }^{45}$

Jack Donnelly's (2007) general international human rights theory text examined the evolution of international human rights regimes, links with foreign policy, case studies on state violations, genocide, terrorism and globalisation. He had earlier authored a more specific text on universal human rights which examined many of the primary themes in this area: the concept of human rights and their foundations, how they work and how they link with human nature, different types of rights (from individual rights to state rights), as well as looking at how rights have traditionally been aligned with liberal democratic welfare states and how they fit with market economies (Donnelly, 2003: 7$21,22-37,57-69)$. As the title suggests, one of the broad themes of the text is the universality vs cultural relativity debate (Donnelly, 2003: 37-58). ${ }^{46}$ However, this

\footnotetext{
44 Lauren's major 2003 text on the evolution of international human rights was nominated for a Pulitzer Prize.

45 See also New Zealand work in this area such as: MFAT (2003: Chapter 1) on the nature and history of human rights; and Marshall on the historical emergence of human rights, and a very useful section which precedes this on semantic and conceptual problems with the term 'rights' (Marshall, 2001: 27-30).

46 Conde gave useful definitions of these terms. Universality: 'A doctrine/theory that says all human rights are held by all persons in all states and societies regardless of race, color, nationality, religion, language, or ethnic traits and must be applied and interpreted in the same way in all states and regions, regardless of the legal system or political ideology'. Universality is often set in counterpoint to those who believe in cultural relativism: 'A theory that holds that all human rights must be looked at, applied, and interpreted according to different cultures and cultural values. ... [and] is raised as a defense mostly by developing and third-world countries who claim that the international human rights regime must be applied relative to a given culture, whose actions would be a
} 
debate (or any of these theoretical human rights issues just mentioned) is not the focus of this research, except to briefly say that it remains one of the most contentious issues in human rights theory. ${ }^{47}$ Domestic implementation occurs broadly against the background of this history and theory, but the concern in this thesis is with the more specific processes and mechanisms of New Zealand's international human rights and how they could be improved to more effectively implement ratified rights.

The study is also about taking a fresh look at the field, acknowledging that the law+litigation area has been well canvassed, but exploring how a public policy approach might be complementary to this. Examining this area from a non-legal perspective should help clarify the processes of how international rights are not only formally adopted in treaties, but how they are transformed in the domestic arena. Much of the research in the international human rights field emanates from legal academics. This also true in New Zealand, and some of the key authors writing about the juncture of international-domestic human rights are Andrew and Petra Butler (2005), Grant Huscroft and Paul Rishworth (Huscroft and Rishworth, 1995; Rishworth, 2003, 2004) and Philip Joseph (2007). They have all written extensively about the implementation of NZBORA 1990 (with its long title link to the ICCPR) through the domestic courts. When the Act had been in place for five years Huscroft and Rishworth (1995) edited a volume on both NZBORA and the Human Rights Act. Many questions had been raised by the new Act as legislators and the judiciary found themselves in an increasing rights environment. Their volume clarified both the larger relationship between international and domestic law and gave a detailed examination of how the two Acts have affected New Zealand law. Comparative analyses were also made with other jurisdictions.

Butler and Butler (2005), writing 15 years after the enactment of NZBORA, provided the largest and closest textual legal analysis of the Act. A large part of their commentary looked at substantive rights contained in the Act and the remedies available under it. They particularly looked at the issue of the justified limits on these guaranteed rights, and also made detailed comparisons between this Act and similar provisions in other

violation in one culture but not in another' (Conde, 2004: 268, 55-56). See also Sajo (2004), which examined universalism and a number of other related issues such as localism and paternalism.

47 For example some extreme cultural relativists argue for the 'right' to preserve practices such as female infanticide and arranged marriages despite lists of universal human rights such as the UDHR which asserted the right to life and the right to marry freely. The language of a 'right to cultural differences' is therefore used as a counter-argument to the rights that have been identified in the West as acceptable. There is a vast literature on the tensions caused by this debate including Steiner, Alston and Goodman (2008: Chapter 5), Lauren (2003: 216, 226, 263-264, 285, 298), Marshall (2001: 35-42) and Leiser and Campbell (2001: 87-104; 285-302). 
jurisdictions. The more recent text by Joseph (2007), which focused on constitutional and administrative law in New Zealand, contained a final chapter on NZBORA. He also looked at similar themes: the application of the Act, justified limitations, the impact of various bills of rights cases, the link with international standards, and the remedies available.

The case studies in this thesis take a slightly different approach to these authors. The research into this area is not legal analysis, but an illustration of how Baigent's Case and the review of the military justice system affected the state sector in different ways. That is, this research is looking at the public policy and human rights implications that sit behind the legal issues these authors focus on. In both case studies NZBORA was being looked at in conjunction with the ICCPR and it was their combined effect on New Zealand domestic jurisprudence - one questioning sufficient remedies and the other highlighting international-domestic law inconsistencies - that resulted in changes to law and policy.

The second broad field of public policy seeks essentially to provide theory and practice about how governments might achieve their objectives. Since the implementation of human rights is one such objective, it follows that there should be considerable room to learn from public policy literature. Here it is noted the definitions of public policy given by UK author Wayne Parsons (1995), as well as New Zealand academics Richard Shaw and Chris Eichbaum (2005), are used to help analyse the similarities and differences between human rights and public policy. Parsons for instance said public policy is broadly about 'the public and its problems' (1995: xv). The implementation in this area is as much about the way government 'works' to deal with the public and its problems as it is about human rights. It highlights that government works across a wider area than just law+litigation.

It is true that, in the practical operation of government, boundaries might be continually contested concerning the intrusion of the state into the rights of citizens. But sometimes those rights demand state action, not inaction. This is, of course, mirrored in the role of international human rights bodies who are also contesting the parameters of intrusion or not into the sphere of state sovereignty. The notion of parameters to intrusion is part of the classic first generation protective rights, e.g. search and seizure, which are about the government passively not intruding into the personal space of citizens. What this 
research suggests is that governments need to actively implement second generation rights, i.e. have a positive obligation to citizens, but these rights are not about intrusion but about provision (resources permitting). This proactive role of governance requires different techniques, often away from the law+litigation model. Effective regional healthcare, for instance, might occur through a range of policies and practices and not primarily through legislation.

Throughout the thesis three links are made to the policy literature:

- The first is about suggesting that the growing international attention to whole-of government approaches would be helpful for more effective human rights implementation domestically. In New Zealand this is reflected in the joined-up government work of Ryan et al (2008) and the coordinated state agencies work of the State Services Commission $(2004,2008)$. As yet explicit connections to human rights in this literature cannot be found, and this is an area of potential further development.

- The second is looking at the literature that does exist (e.g. Geiringer and Palmer, 2007) on human rights and 'social policy' in New Zealand. ${ }^{48}$ Their article seems to be one of the few attempts to tackle the linkage between these fields, although it is about a rights-based approach to social policy (not public policy generally) and therefore mostly focuses on more precisely defining New Zealand's obligations in relation to economic and social rights. On reflection it is not surprising that there is no strong link between say public policy generally and civil and political rights, as the latter are broadly protected in legislation. Also if the human rights field potentially has different relationships to 'social policy' and 'public policy', this suggests there is room for there also to be unique relationships between human rights and other types of policy: defence policy, economic policy, education policy, foreign policy, health policy, housing policy, macro-economic policy, population policy and privacy policy. This research is

48 This article is a 'revised and abbreviated version' of a 2003 issues paper by these authors that had been commissioned by the HRC (see Geiringer and Palmer, 2003). They defined social policy as 'the principles and mechanisms by which government seems to affect the development of society, particularly in relation to health, education and welfare' (hence their emphasis is on second generation rights), and a rights-based approach to policy as 'one that ensures that policy is formulated within the parameters set by New Zealand's human rights obligations, as found in domestic and international law' (Geiringer and Palmer, 2007: 15). A similar UK article written in the same year looks at re-thinking the engagement between social policy and human rights, and also had this focus on how second generation rights can be implemented more effectively (Dean, 2007: 1-2). 
about trying to make links between public policy and human rights, because the several issues that will be raised later in the thesis at the beginning of Chapter 4 relate to public policy and the implementation of New Zealand's human rights system and not social policy which (as Geiringer and Palmer noted) mainly relates to health, education and welfare.

- The third is a synthesising exercise, drawing together all the brief mentions of public policy/work of policy makers in the evaluation and planning initiatives/documents set out in Table 4 (see Section 4.2). This has enabled a clearer picture to be gained of the relationship between public policy and human rights. Policy work is important in the human rights field because 'done well' (i.e. robustly) it takes the international treaty obligations and looks wider than their incorporation into law and at all the possibilities that could be relevant to a particular treaty right. Also, done well policy making come to grips with the obligations of states to citizens, but if this role is compartmentalised instead of being thoroughly integrated with the law+litigation approach it adversely affects the effective implementation of rights.

This research therefore adds to this literature base in a number of ways. It echoes the human rights history field by suggesting that the development of the sixth stage of robust human rights governance is not the end of this history, but that it will evolve and continue over time as new challenges arise. The thesis further adds to the literature above by: developing the notion of robust human rights governance (if fully functioning it would give appropriate weight to policy and legal approaches); and suggesting there can be differing reactive and proactive approaches - which can be policy or legal - to human rights issues (with case studies to support this). The concept of complementarity is intended to be the core addition to the field, and it is hoped it will produce some useful insights for both areas. The broad thematic sweep is therefore that with 'best practice' the implementation of human rights tends towards a more whole-ofgovernment way of operating where policy approaches work alongside law+litigation, and where international and domestic become increasingly 'interwoven'. These interweaving fields are used to develop the concept of complementarity. 


\subsection{Summary}

This thesis explores how international human rights obligations have been given effect in the New Zealand state sector. This research looks at how human rights considerations are becoming central to domestic and international policy making and government generally, and how this has steadily impacted on the state-citizen relationship. There is no single beginning (or end) to this process. However, for the purposes of this research, the UN Charter 1945 can be taken as commencing the current system for international protection of human rights, with New Zealand amongst the founding members. Other developments quickly followed internationally with the UN General Assembly's 1948 UDHR leading the way towards the current international human rights architecture. New Zealand's acceptance of the obligations of the resulting human rights covenants and conventions began the interaction that is the essence of the complementarity process. Since New Zealand helped form the international system, its own domestic environment was welcoming for human rights implementation. Yet even in this country there has been a considerable learning process. This chapter has started to look at the convergence between the law+litigation and policy approaches, and this will clarify throughout the research. Before going further it is necessary in the next chapter to clarify the key contexts applicable to this thesis. 


\section{CHAPTER 2: KEY CONTEXTS}

The processes of giving domestic effect to international human rights obligations take place in the real world of states with their own histories and traditions. The concept identified as complementarity has unique features reflecting historical and constitutional contexts. This includes the inter-relationship between international human rights and public policy, which should enrich the theory and practice in both areas. All this must be understood within the historical context of this country as it relates to human rights, which is therefore outlined here. Much of what is in the research, however, is not New Zealand-specific - the ideas of complementarity and effectiveness are not limited to one country. This chapter starts with New Zealand's constitutional framework as this is relevant to understanding the domestic scene.

\subsection{Constitutional framework, Westminster parliamentary tradition and rights}

Giving effect to international obligations, especially if these involve basic rights, by definition involves constitutional issues. The processes involve direct limitations on state power, direct obligations for how state power must be used, and the entire operation of the international legal and political system in which states function. All this is well discussed in the general literature on states in international law and in domestic constitutional law in various jurisdictions. The parallel in the New Zealand experience, even accepting its differences, can be seen in key texts (Butler and Butler, 2005; Huscroft and Rishworth, 1995; Rishworth, 2003; Joseph, 2007). For the purposes of this research the focus is on the interaction with international obligations and on how the state has actually worked (and should operate) to foster complementarity. Examining these processes requires a brief explanation of the formal processes by which New Zealand governments 'accept' international obligations, and some of the background to this country's constitutional framework.

Giving domestic effect to international obligations typically happens via two primary mechanisms: legislating the obligations into domestic law; and government 
consideration of policies and practices for better 'implementation'. As will become clear the first is foundational and well examined (for instance in the key texts just mentioned), but the second of government policies and practices is less so. As regards legislating, there is no automatic uptake of UN instruments into New Zealand's domestic legislation. In some countries, however, treaties automatically become part of domestic law once ratified.

An example of this automatic incorporation into domestic legislation is South Korea where under Article 6(1) of the Republic of Korea Constitution 'generally recognised international law' has the same effect as the domestic laws of that country (NZ House of Representatives, 2005: 55). On the other hand in New Zealand 'treaty-based international law only becomes part of the domestic law by an Act of Parliament' (New Zealand House of Representatives, 2005: 56). Martin Scheinin called the Korean-type approach 'a treaty-specific incorporating statute' as opposed to the Swedish situation (similar to New Zealand), which is a 'transformation' instead of an 'incorporation' method', and the transformation occurs by amending domestic legislation in line with treaty obligations (Scheinin, 2001: 49, 50). Elisabeth Eid names the Korean-type approach 'self-executing' and noted that in Commonwealth countries (e.g. New Zealand, Australia, Canada and the UK) there is no automatic uptake of international treaty obligations through the domestic courts and that a dualist incorporation process occurs. This dualist approach is where international human rights treaties 'do not form part of domestic law but serve as an important interpretive tool for domestic legislation' (Eid, 2001: 2-3, 10). That is, they sit to the side of domestic law as a powerful interpretive influence that judges must consider.

As noted in the last paragraph, the formal legal position in New Zealand is that treatybased international law only becomes part of the domestic law if implemented by an Act of Parliament. However, there are four related areas in which treaty-based provisions might have some domestic effect even without incorporation in a statute. First, the common law presumption that Parliament does not intend to legislate contrary to its international obligations so courts interpret legislation to give effect to the treaty obligations if that is plausible. Secondly, courts can respond to explicit adoptions of international treaty obligations by expanding the judicial scope in relevant cases. This was one of the reasons for the court's adoption of a damages remedy in Baigent, but NZBORA explicitly stated anyway that one of its objectives was to give effect to the 
obligations under the ICCPR. ${ }^{49}$ Thirdly, it has always been part of the common law, that 'customary international law' is part of the common law and given effect to in domestic courts.

Fourthly, and of key importance for this thesis, the same presumptions of intention to comply with international obligations (as the comments from the Minister of Justice that opened this thesis illustrate) increasingly operate in relation to the public sector. For example, even for a non-treaty standard, such as the United Nations Standard Minimum Rules for the Treatment of Prisoners, the Corrections Department must not breach these irrespective of whether these have any domestic statutory base. Similarly, irrespective of whether NZBORA had been in effect, it is arguable that changes to the military justice system (in Chapter 8) should have been made to comply with the obligations under the ICCPR. The critical difference from the other three examples, however, is that administrative policy and implementation could take place without having to be litigated in a court. The combination of progressive legal and administrative 'effect' in New Zealand law and policy therefore stems from the same expectation: that the Crown's acceptance of international law obligations requires not only courts, but all organs of state, to give effect to the obligations if possible. In this thesis, the focus is on the public sector, but as acknowledged, the legal issues are interconnected.

As noted by the Minister of Justice, Simon Power, at the NZ Diversity Forum 09, New Zealand takes a very cautious approach and ratification only occurs once domestic legislation, at least, complies with the international treaty in question:

... unless we are able to fully back it and do it with integrity in a domestic setting [we do not sign them. This involves making] the hard calls at home to be fully compliant, compared with some other member states that approach ratification from a slightly different tack (Power, 2009).

49 In Tavita v Minister of Immigration [1994] 1 NZLR 257 (about an Immigration Service removal order), the court expressed similar sentiments that might be said to have anticipated these developments, but without any specificity in that particular case. In Tavita the Court looked at whether the Minister of Immigration should have taken account of the ICCPR and UNCROC (as there was a child involved) in making the removal decision. The Court noted in this request for judicial review that: 'since New Zealand's accession to the Optional Protocol the United Nations Human Rights Committee is in a sense part of this country's judicial structure, in that individuals subject to New Zealand jurisdiction have direct rights of recourse to it. A failure to give practical effect to international instruments to which New Zealand is a party may attract criticism. Legitimate criticism could extend to the New Zealand Courts if they were to accept the argument that, because a domestic statute giving discretionary powers in general terms does not mention international human rights norms or obligations, the executive is necessarily free to ignore them. This emerges as a case of possibly far-reaching implications. ... Universal human rights and international obligations are involved'. 
Diplomatically, he was drawing attention to the varied record of effective implementation of international obligations throughout the world. One might surmise that policies and practices should automatically fall into line with the law, on the assumption that the rule of law functions as theory suggests. But even in this country, more is needed for effective implementation.

All states have their own traditions and these inevitably affect the processes by which international obligations become part of domestic law and practice. In New Zealand's case, it is necessary to understand the historical role of Parliament in protecting rights, initially against the monarchy, because this history has continued to shape how this country has given effect to its international obligations. There are two aspects to the Westminster tradition as it developed in New Zealand. The first concerns who is seen in the monarchy/parliament/court triangle to be the principal defender of citizen's rights. Following this, the second explains why parliamentary-based protection has been relied upon instead of an entrenched bill of rights in this country.

The relationship between Parliament, its legislation and the courts is discussed in this research, particularly in the Baigent case study. This relationship links historically to the 1215 Magna Carta and the 1689 English Bill of Rights, elements of which are still part of this country's law. New Zealand's second periodic ICCPR report to the UN Human Rights Committee in 1990 for instance stated that fundamental statutes from UK law such as the Magna Carta continue 'to control important aspects of the relationship between individuals and the state' (MFAT, 1990: 3). The Magna Carta ensured the king could not arbitrarily imprison people or deprive them of property, and the 1689 English Bill of Rights also asserted that the monarch could not interfere with the law, establish new courts or act as a judge, impose taxes by royal prerogative, or impede free speech or proceedings in Parliament. Over centuries in England, Parliament took on the mantle of defender of the people against the monarchy - and the settler governments in New Zealand picked up this tradition (Joseph, 2007: 3).

This role is not, however, static or unending. For instance Sir Geoffrey Palmer in Unbridled Power argued that in New Zealand, Parliament had in the late 1970s become too powerful. In the doctrine of the separation of powers the legislature, executive and judiciary form three branches of government that are supposed to be separate. He argued that 'in New Zealand the Government in office effectively controls both the 
legislative and executive branches' (Palmer, 1979: 5). This was originally written prior to the introduction of NZBORA and MMP - a bill of rights and a different electoral system both being suggestions he had made in that book to redress this concentration of power. The doctrine of the separation of powers is meant to act as a checks and balances system. Another feature of the parliamentary tradition is summed up by the doctrine of parliamentary sovereignty, which in essence means the courts cannot override Acts of Parliament. This 'parliamentary supremacy' also helps explain the status of NZBORA in New Zealand constitutional law as an ordinary Act of Parliament that can be amended by any other Act, rather than as 'supreme law' which ordinary Acts have to comply with.

The parliamentary tradition is so strong in New Zealand that despite fears of the parliamentary dominance suggested in Unbridled Power, there appeared to be little public (or parliamentary) support in New Zealand for an entrenched bill of rights when the opportunity arose. The debate heightened in this area in the mid-1980s, and a White Paper was finally written with the help of the Legislation Advisory Committee (Department of Justice, 1985). ${ }^{50}$ Canada, South Africa and the USA have entrenched bills of rights but three Westminster system countries (New Zealand, the UK and Australia) do not. Instead the first two now have unentrenched legislative bills of rights. Australia has none at the national level, although the Australian Capital Territory (ACT) and Victoria have unentrenched legislative bills of rights similar to the New Zealand model. So why did New Zealand steer away from an entrenched bill? Despite pressure from the UN treaty body committees over several reporting cycles, one reason was that the historical traditions of 'faith in Parliament' were too strong. Successive New Zealand reports therefore argued that human rights were sufficiently protected legislatively and in other ways within this country's constitutional traditions. The second periodic ICCPR report for instance stated: 'Human rights continue to be afforded protection by the long established and well entrenched precepts of the common law and by legislation' (MFAT, 1990: 3).

Another reason relates to the Treaty of Waitangi and the need for its careful placement in any new constitutional framework. Butler and Butler have written about the

50 For a discussion on the White Paper and the events leading up to the enactment of NZBORA see Butler and Butler (2005: 25$33)$. 
arguments for and against an entrenched bill of rights and what factors needed to be taken into account. They noted that Matthew Palmer had asserted at the time (1985) that the Treaty would need to become part of the proposed entrenchment, because if not included 'a bill of rights could be seen as relegating the Treaty and the rights of the Maori under it to a second class status' (Butler and Butler, 2005: 27). The NZ Constitutional Arrangements Committee that reviewed the issue of the balance of powers in 2005 also noted the Treaty and its constitutional importance: 'it became clear to us that a core issue at the heart of New Zealand's constitution was the balance of authority between the judicial and legislative branches of government and the authority of Parliament in relation to the Treaty of Waitangi' (NZ Constitutional Arrangements Committee, 2005: 15). In their view one of the key questions to be asked in the future was about the relationship between the three branches of government, and whether courts could override legislation if fundamental rights were breached (the very issue at the heart of the balance of powers discussion). Another issue they believed could be further explored was '.. the relationship between New Zealand institutions of government and international law-making bodies, including questions about the way in which the government can enter into international commitments; and whether international laws can become part of the New Zealand domestic law directly, without parliamentary involvement' (NZ Constitutional Arrangements Committee, 2005: 16). These comments stress the importance of a balanced constitution, and as these issues are not fixed for all time there will of course be ongoing discussion about the appropriate balance.

However, five years after that 1990 report a deeper reason was given to the UN Human Rights Committee about not going down the entrenchment route. By the time of the third periodic ICCPR report in 1995 the committee was still concerned that NZBORA 'has no higher status than ordinary legislation' (MFAT, 1995: 69). The reason given by the New Zealand delegation back to the committee was that after five years of debate on the subject it was decided that 'New Zealand was not ready for an entrenched Bill of Rights' (MFAT, 1995: 39). Public opinion was wary of entrenchment because of the possible redistribution of power from elected representatives to an appointed judiciary. In the final analysis it was fear of 'judicial supremacy', not parliamentary dominance, which shaped the New Zealand approach i.e. there was insufficient support for overturning the historical balance of power between Parliament and the courts. Although raised at times throughout the research, this theme of 'judicial 
supremacy' (sometimes termed judicial activism or juristocracy or the power of the courts vs that of parliament) is not a major focus of the research and it has already been covered extensively elsewhere. ${ }^{51}$

Having seen that various countries approach ratification in their own way, it is also the case that implementation in each country occurs in a national context. Each state has its own ideological underpinning (liberalism, socialism, fascism etc), which can be more or less 'receptive' to the human rights endeavour. Human rights theorist Jack Donnelly captures this well when he stated the link between liberalism and human rights and its relationship to their effective implementation:

\begin{abstract}
The idea of human rights received its first mature expression in, and remains deeply enmeshed with, liberal social contract theory, the only major tradition of political theory that assumes that individuals are endowed with equal and inalienable rights. And the contractarian notion of the state as an instrument for the protection, implementation, and effective realization of natural rights is strikingly similar to the conception of the state in international human rights instruments. Both measure the legitimacy of the state largely by its performance in implementing human rights (Donnelly, 2003: 35).
\end{abstract}

The New Zealand state has been particularly receptive to human rights for some decades. The domestic political culture and a public philosophy here at the time of the UN Charter 1945 may not have articulated such concepts in terms of formal human rights laws, but clearly the concepts were reasonably well formed. In this way key policy and legislative changes affecting what later became basic rights were evidenced well before the international human rights framework had begun to influence New Zealand in the 1940s. By the period where this research picks up (the mid-1940s), this country already had a tremendous base upon which to build its framework i.e. it was steering in that direction of its own accord. Many historical struggles and social dynamics have generated rights demands in New Zealand. These have included that economic and social rights were hard won in this country and advancements had been made well before the efforts of Prime Minister Walter Nash at the 1944 ILO Conference in Philadelphia, and Prime Minister Peter Fraser at both the UN Conference in San Francisco in 1945 and discussions about the UDHR in 1948. For instance, universal free education was introduced in 1877, and the Old Age Pensions Act passed in 1898. The

\footnotetext{
51 See for instance: Butler (2004) which looked at whether the Court of Appeal has been activist in its decisions about human rights; Thomas (2005) about judicial activism in relation to human rights and judicial constraints on judges; Kirby (2005), a defence of the judiciary against charges of activism; Arnold (2005) which also claimed that judicial activism is misconceived; Waldron (2005), a response to the Hon Michael Cullen's comments on the role of the judiciary; and Allan and Geddis (2006) which responded to Waldron's article and made comparative comments about the Westminster and USA systems.
} 
1935 Labour Government also began work on a comprehensive social welfare system coupled with increased labour standards (MFAT, 2008: 12; UNGA, 2009a: 4).

Other rights issues have included controversy about participation in the Vietnam War in the 1960s and 1970s, and the effect this was having on the social and economic rights of civilians. Further controversy arose about sporting contacts with South Africa, especially around the time of the 1981 Springbok Tour. Sanctions were carried out by the UN and the Commonwealth towards South Africa and the former Rhodesia over this issue. There has also been vocal opposition to French nuclear weapons testing, with the sinking of the Greenpeace ship The Rainbow Warrior in Auckland in 1985 as one chapter in this history. Again, in the late 1970s and early 1980s there was growing concern about the abuse of central executive power during the office of Prime Minister Robert Muldoon. ${ }^{52}$ Other areas also gained high profile and the list in Table 3 of human-rights related legislation (see Section 4.2) gives a glimpse of the important issues developing in this period and through to the 1990s: civil liberties; privacy; gender and same sex rights, including equal pay; disability rights, parental leave, abolition of the death penalty, children's rights, domestic violence. Other concerns have been the effects of state deregulation and privatisation; increasing economic and social inequalities; and environmental rights.

New Zealand, then, is a country with a long and varied rights history that has shaped its own unique national human rights context. However, not only the national context, but the type of government and constitutional arrangements, can result in different levels of complexity in terms of implementation. For instance New Zealand (with a unicameral parliament and an unentrenched legislative bill of rights) has fewer factors involved than other common law states such as Australia, Canada, the UK and the USA. Each of these countries has different constitutional factors in the mix, including bi-cameral parliaments, entrenched constitutions, internal federal state systems, and ratification of more or less enforceable regional human rights treaties. The UK for instance now has a very complicated human rights constitutional framework with four factors involved. Like New Zealand there is an unentrenched UK Human Rights Act 1998, which was partly modelled on NZBORA. However, there is a bicameral Parliament so all Bills have to pass through both an upper and a lower house. A further layer is the close 
alignment between UK human rights domestic law and the European Convention on Human Rights that came into effect in 1953. This is an enforceable regional treaty that is overseen by the Council of Europe based in Strasbourg. The Council also administers the full-time European Court of Human Rights. The UK ratified the convention in 1998 and it was incorporated into British law almost completely. Jonathan Black-Branch, an international and comparative law professor who has recently visited New Zealand believed the UK Human Rights Act 1998 is in effect the European Convention on Human Rights plus two modifications (Black-Branch, 2009). This means that if UK citizens exhaust remedies in that country they can appeal further to the European Court of Human Rights. This set-up makes for an extremely complex human rights framework in the UK, a situation that is likely to be replicated in other countries if they directly incorporate enforceable regional treaties into domestic legislation.

Federal systems and regional organisations have layers of rules and laws that can make implementation more complex. It is beyond the scope of this thesis to look into this, but comparative research could produce rich insights about how the type of government and constitutional arrangements affects how difficult or easy it is to implement international treaty obligations. The literature on this appears to be quite sparse, although it is worth consulting papers by Elisabeth Eid (2001), a Senior Counsel in Human Rights Law with the Canadian Department of Justice, and USA doctoral students Caroline Payne and Kaitlyn Sill (2008). Eid noted that international treaty ratification normally only occurs if the Canadian provinces and territories support this. She believed the Canadian system is therefore 'one of the most difficult places in the world' to implement these treaties, partly because of this system of federalism and other constitutional factors (Eid, 2001: 2-3). The exploratory paper written by Payne and Sill looked at constitutional implications from a slightly different angle. They isolate three domestic constitutional factors - constitutional supremacy clauses, judicial independence, and the separation of legislative and interpretation powers - to see if any of these result in a state having more respect for the rights of their citizens and not (as this research is suggesting) their effect on the implementation of ratified treaty rights (Payne and Sill, 2008: 4). Their preliminary findings were that while the last two fail to have any significant impact, the first factor is important because with a constitutional supremacy clause '.. the government cannot simply nullify or circumvent them through its traditional lawmaking actions' (Payne and Sill, 2008: 7). This, they felt, is particularly important when a country goes through a regime change. Research such as this confirms an earlier 
point made that the uptake of human rights occurs in a different context in each country. It is not a simple equation that 'treaty ratification = improved human rights'. Payne and Sill suggested that further study was necessary to look at the effect of these three constitutional factors more carefully (Payne and Sill, 2008: 22-23). ${ }^{53}$

Having noted these comments about the Canadian system, it also the case that the Canadian Charter of Rights and Freedoms (1982) is almost identical in wording to NZBORA. Butler and Butler stated that the relevance of: 'the Canadian Charter ... to BORA is clear. Much of the drafting of the proposed supreme law Bill of Rights in 1985 was based on the provisions of the Canadian Charter, while the accompanying commentary drew significantly on the experience in Canada ...' (Butler and Butler (2005: xi).

A final clarification is that the focus on implementation of human rights standards takes as given some very basic aspects of constitutional governance, including criminal lawpunishment and the all-encompassing concept of the rule of law. Thus, it will be obvious that in the development of the common law alongside democratic government over the centuries, some aspects that relate to protecting-implementing human rights were shaped by the criminal law and associated judicial procedures. For example criminalising homicide is one aspect of protecting the right to life. Similarly, the writ of habeas corpus (and the enforcement aspects of contempt of court) is a judicial procedural protection of the right to liberty (no detention without lawful cause). Jack Donnelly (2003: 34) made a related point that: 'This focus on state-citizen relations is also embedded in our ordinary language. The human rights of a person who is beaten by the police have been violated, but it is an ordinary crime, not a human right violation, to receive an otherwise identical beating at the hands of a thief or an irascible neighbour'. At its most general, however, it can be argued that the development of the rule of law across centuries has shaped public sector conduct to protect citizens against arbitrary, unjust, unfair and unlawful actions.

\footnotetext{
53 The New Zealand Values Study 2005 has asked the same question about respect: 'How much respect is there for individual human rights nowadays in New Zealand?' Their findings were that $22 \%$ felt there was 'a lot of respect', $59 \%$ 'some respect', $18 \%$ 'not much respect', and 2\% 'no respect at all' (Rose et al, 2005: 8). The study concluded that there was an age factor in the responses, with those '... 45-54 more likely to consider there is a lot of respect or some respect compared with respondents 25-34 and 65+ years' (Rose et al, 2005: 8). Similarly, education was a factor, because 'more educated respondents perceived that there is a lot or some respect for individual human rights compared with less educated respondents' (Rose et al, 2005: 8). Given that over $80 \%$ of respondents felt there was respect, this indicates very high public support for the international global human rights enterprise.
} 
Accepting the importance of such broad perspectives, the focus in this thesis is on more specific and current methods by which the state sector is taking an increasingly proactive and comprehensive role in relation to human rights. While the criminal aspects of the implementation of human rights are noted where they are relevant (e.g. in the Baigent case study and the reform of the military justice system), the focus here is on the responses from state actors. For instance, there is an examination in the first case study of how the NZ Police responded to the Baigent decision. Also the second case study about the military justice system essentially shows that because of analysis and policy advice, an entire justice process in breach of international human rights obligations was proactively reformed in advance of challenge before the courts. The technique of making a particular conduct an offence has been abundantly well studied (e.g. Simester and Brookbanks, 2002; Robertson, 2010), as has the importance of the rule of law both historically and currently (Thompson, 1985; Palombella and Walker, 2009).

\subsection{Relationship between human rights and public policy}

The relationship between human rights and public policy is now clarified because the interaction between these fields is a key context for the research. The way terms are used across disciplines can be different, and Victor Conde's definition of 'implementation' from a human rights perspective has already been given earlier in Section 1.2.3 (Conde, 2004: 118-119). While the human rights literature uses the term 'implementation' in this way to refer to legislation and similar policy actions, it is quite conventional to also see implementation in the policy literature as the 'operationalisation' of legislation: if a right is implemented in a law, then the law is implemented when resources are mustered to carry it out.

With a 'human rights implementation lens', the focus is on how treaty rights (e.g. UNCROC) actually work in the international arena, across the entire state sector, and in society at large. More broadly the term 'implementation' is central to the field of public policy, summarised as the theory and practice of how government objectives are achieved (or not achieved). The general guidance given to public servants on their obligations to the law and to the elected government of the day can be found in Crown Law Office (CLO, 2005) and State Services Commission (SSC, 2004, 2008) guides. 
These latter two dealt with the problem of complex inter-departmental issues - and human rights implementation can be seen as such an issue. ${ }^{54}$

This raises an important question that is useful to discuss at an early stage of the arguments of this thesis: (1) 'Is human rights implementation just another public policy puzzle for officials/government?' Put differently: (2) 'Is there something about international human rights obligations that at least puts implementation in a special category of public policy challenges?' This research answers are 'yes' and 'yes' to both questions. Why the answer to the first question is 'yes' is discussed, and then in relation to the second question it is shown that there are aspects of the human rights focus that are 'special'. Explaining the reasoning early in the research helps to set out the conceptual foundations for the arguments throughout and I now answer these two questions in detail.

(1) Is human rights implementation just another public policy puzzle for officials/government?

Processes that should ensure that New Zealand upholds its international human rights obligations (and of course other international obligations) are today more or less ingrained in ordinary government business. This is not to say that all aspects of policy are always identified through international human rights obligation 'lenses'. Some domestic policy goals might be pursued irrespective of their connection with these obligations. Two examples illustrate this. Preventing (or at least reducing) child abuse has been a public policy goal for successive New Zealand governments. Obviously one aspect of this goal relates to obligations under UNCROC, but achieving the goal involves very complex domestic public policy interventions across the whole-ofgovernment including health, education, social welfare, employment, housing and justice/police/courts. Having said that, much day-to-day policy discourse is already framed in rights terms. Does it add anything to this complexity of policy goals to focus on human rights obligations? This question will be returned to below.

A second example is that (again) successive governments have also set goals for reductions in how many people die each year on the roads, summarised as 'the road

54 The State Services Commission (2008), for instance, gave guidance to departments needing to implement new initiatives. However, see Ruth Herbert (2009) who looked at the difficulty of implementing strategic policies across multiple government departments and asserted that there needs to be much more direction given in this area. In her view the Australian Government gives a better lead to their state sector agencies and she claimed their model is useful for New Zealand. 
toll'. In terms of human rights it is possible to point to the right to life in the ICCPR and NZBORA. But primarily this goal is also best seen within the standard public policy techniques available such as allocations of funding alongside changes in policing, road construction, advertising, random testing, concentrating on the biggest risks, and punishment for those who create most risk (like speeders). In both examples (child abuse or the road toll) the complexity of issues suggests that whole-of-government approaches are likely to be most useful, including cross-agency officials committees to come to grips with multi-faceted problems and objectives. This clearly suggests that human rights issues are therefore everyday reflections of the general problems of 'governing to achieve objectives'. Further support comes from the core features of the public policy literature. Wayne Parsons for instance noted that:

Public policy focuses on what Dewey (1927) once expressed as "... the public and its problems". It is concerned with how issues and problems come to be defined and constructed and how they are placed on the political and policy agenda. But it is also the study of ... "what governments do, why they do it, and what difference it makes" (Parsons, 1995: xv).

Using Harold Lasswell's terms he stated that the policy orientation can be summarised as:

\begin{abstract}
... multi-method; multi-disciplinary; problem-focused; concerned to map the contexuality of the policy process, policy options and policy outcomes; and whose goal is to integrate knowledge into an overarching discipline to analyse public choices and decision-making and thereby contribute to the democratization of society (Parsons, 1995: xvi).
\end{abstract}

Much of this can also relate to the human rights field, which involves the public and its problems. Rights issues go on and off the government agenda and the field is obviously about what governments 'do'. It involves multi-method and multi-disciplinary approaches (law, politics, policy, education, health etc). It is problem-focused. It is concerned to find the appropriate processes, options and outcomes. Public choices and decision-making are involved and so is public funding, and all aspects are intimately connected to the democratisation of society. The connections can also be seen in Parsons' summary that public policy involves problem solving in the following sequence:

Issue (people sleeping on the streets); Problem (homelessness); Policy (more housing) (Parsons, 1995: 87).

A human rights lens would similarly identify the 'issues' (right to housing being either denied or not delivered) and pose 'problems' (risk of legal suit, international embarrassment in reporting a high degree of homelessness, political pressure from 
voters/Parliament) that may need 'policy' responses (task force). Richard Shaw and Chris Eichbaum also defined four broad aspects of the public policy field:

$\ldots$ it involves government, decisions to act (and decisions not to act), entails the commitment of resources, and has a normative dimension (Shaw and Eichbaum, 2005: 3-7).

In short, the goals and methodologies of public policy generally clearly apply to the field of human rights.

However, Mark Considine gave another view on public policy that represents a less instrumentalist approach. He distinguished between the standard view of public policy, similar to that set out above, and an alternative one. The first is summarised as: 'A public policy is an action which employs governmental authority to commit resources in support of a preferred value' (Considine, 1994: 3). With the alternative approach there is an:

\begin{abstract}
... interdependence between key social actors such as parties, corporations, unions, professions and citizens. It is suggested here that it is the character of these systemic dependencies which shapes behaviours, problems and solutions. ... policy is [therefore] the continuing work done by groups of policy actors who use available institutions to articulate and express the things they value. The significance of these systemic activities cannot be under-rated. Public policy is one of the central processes through which our communities respond to major social, economic and environmental problems. They shape and determine the health, welfare, education and the developmental opportunities of every citizen. The flexibility and creativity found in policy systems are therefore of interest and significance at every level of social life (Considine, 1994: 2,4).
\end{abstract}

The standard view he likened to examining 'policy as a purely technical matter', where the analyst seeks to estimate the strength and weakness of the available mechanisms for achieving a stated goal (Considine, 1994: 7). This could be applied to the homelessness problem just raised. In his view, however, the process is more like 'a succession of episodes', all occurring within larger 'policy systems' (Considine, 1994: 7, 8-9). These systems have four components: the policy actors and policy institutions mentioned in his definition above, but also political economy (broadly 'the structure of key relationships') and policy culture (broadly values) (Considine, 1994: 9). Drawing these four components together: 'As a result policy systems need to be understood as complex structures for political learning and memory' (Considine, 1994: 47).

Public policy issues therefore arise, the key actors become involved, and institutions are used to obtain results that are consistent with the values underlying the policy culture. As each episode arises, there is much learned and this political memory stays in place 
for when similar episodes occur in the future. Considine's theory is more complex than Parsons' 'issue/problem/policy' approach and it becomes helpful for the discussion in Chapter 7 on the emergence of a human rights governance level. Here, the standard public view, which is linear and non-complex, does not adequately deal with the multidirectional aspects of this governance level, but Considine's approach provides a better way of understanding it.

Is there something about international human rights obligations that at least puts implementation in a special category of public policy challenges?

As regards this second question, human rights implementation has characteristics that give it a 'special' dimension in the field of public policy. Because of the increasing interconnection of international law in all dimensions of public policy, the aspects that make up that special dimension are matters of degree rather than clear distinctions. Here five of these aspects are outlined, and discussed in more detail below:

- the global extent and historical depth of the human rights enterprise

- the pervasive influence at the domestic level

- the extra layers over and above domestic policy goals

- the progressive timing involved, and

- most simply, the legal framework of 'rights'.

In terms of the first characteristic, the human rights system is an enormous global endeavour that has involved many countries since the 1940s. This scope is different from much of the domestic public policy programme of any individual state. But 'globality' is not of course confined to human rights and might today also be said to be true of many areas of apparently domestic activity such as postal and telecommunication services, trade or climate change issues. As well as philosophy and international law, the human rights field also has a deep historical background reflected in the frameworks set up in most western liberal democratic states as the result of wars and changes that redefined the relationship between government and citizen. These included struggles against oppression (either by the state or other actors) at one time or another. The English, American and French formulations of bills of rights of the $17^{\text {th }}$ and $18^{\text {th }}$ centuries were thus responsive to the respective historical developments of their times. They were also forerunners to the extensive human rights architecture set up as a direct response to the global atrocities carried out during World War II, as well as to many state constitutional arrangements all over the world. The background to the 
New Zealand interaction of international human rights standards and the state sector therefore reflects this vast historical canvas.

The human rights system is so large and pervasive globally that it can be conceived of as one step down from asking: 'Is it possible to make an entire state liberal?' That is, human rights is not a political ideology (a type of government such as liberalism, fascism, socialism), but it is very close to that. It could even be considered to be one level down from an ideology, perhaps even a set of principles that constitute a component of the holistic underpinning fabric of the state. The post-World War II human right enterprise has been a very ambitious attempt to say that the entire international law system and individual states should function according to core human rights standards. It was always the intention that the principles set out in the UN Charter and the UDHR would be implemented as parts of state policy, and when the core treaties were developed from the 1960s onwards and countries ratified them this became a reality. In other words it was a post-war ambition to create an entirely different type of state ever: a 'human rights compliant state'. The problem therefore becomes how to the implement the whole of this endeavour.

A second aspect giving human rights a particular dimension in public policy issues is that the multi-faceted parts of the international human rights system reach into almost every element of state policy. The notion of the dignity of the human being, the importance of community, and the way that a state responds concerns the 'social contract' affecting everything that government does. Hence human rights are not only policy prescriptions about how to achieve particular objectives (reducing child abuse or the road toll), but they are about how all government activity is conducted across the board. In the end these are of course constitutional issues.

A third characteristic is that there are extra layers with the human rights field that are not as pervasive in all elements of the domestic public policy arena e.g. treaty ratification, treaty body reporting, the domestic implementation of international rights via three possible mechanisms (laws, policy or practice), and additional state sector work around ensuring consistency with international standards and domestic laws. This pervasiveness is highlighted by the Cabinet vetting requirement that every new Bill or Regulation has to be considered for compliance against international human rights obligations and this applies to areas as seemingly unrelated as fisheries and postal 
regulations. Again, however, these examples illustrate that this characteristic is only relative. These regulations are today also interwoven with international obligations from different sources and New Zealand domestic policy and trade issues affect the economy and much of government policy. In all cases laws, policies and practices are expected to comply with all international obligations, not just those of human rights. Roger Clark (2000: 185, 186), for instance, had commented on the effects of international law on the domestic arena. In his view it could 'set an agenda that obliges states to move programmatically in a particular direction' and changes might 'include both a general policy agenda and, from time to time, specific implementing legislation'. This links with the point in Section 2.2 that the human rights and public policy fields do have points of connection and are mutually influential.

A fourth aspect is that the international human rights regime envisages a somewhat different time-scale of implementation from absolute obligations to progressive achievement (this is especially the case for economic and social rights). In some areas a state makes a commitment 'over time' to ensure treaty-ratified rights can be better realised. But even where there are no such qualifications for implementing obligations, the system of regular reporting pushes states to ensure that across the reporting cycles real progress can be demonstrated. This concept might be particularly helpful for developing states as they struggle to implement obligations. It is also a useful concept for developed nations, such as New Zealand, because there may be ongoing changes needed to ensure better implementation of rights. Progressive implementation is of course also true of domestic policy goals. For example the policy goals of reducing deaths from road accidents or child abuse can be spread over decades. So again the implementation of human rights obligations is different only in scale, not in absolute terms, from the field of public policy broadly conceived.

Fifthly, and perhaps most obviously, the entire legal framework of human rights is distinctive. It is one thing to try to reduce child abuse or deaths on the road; it is another to frame the state as being obliged in law to do so, failing which there are legal consequences for the state including the possibility of financial penalties. However, human rights laws are enacted as a consequence of policy making (government policies underpin laws) so there is a complementarity between these fields as public policy already pays attention to rights. 
Matthew Palmer, in a paper written for the NZ Law Commission and the Crown Law Office, examined the differences between legal analysis and policy analysis. In his view lawyers and policy analysts each 'use an entirely different mode of analysis' and each group needs to fully understand what it is that the other actually does (Palmer, 2006: 3). He also made a point which echoes that of the complementarity understanding in this research: 'the inherent differences between the paradigmatic versions of legal analysis and of policy analysis can cause problems if they are unappreciated. If they are appreciated, the strengths of each approach can be valuably applied' (Palmer, 2006: 3). That is, the law+litigation and policy models work well when in alignment.

To link the human rights system to the public policy field it is therefore perhaps useful to conceive of it not only as a set of important underpinning principles, but also as a foundational system with various levels: macro, meso and micro. It might also be useful to consider 'small p' and 'big P' policies as a way of understanding public policy better:

- At the macro level, containing the most broad-based norms and ideals, it is a system in which individual rights are recognised and valued and the government aspires to ensure that these are maximised given resource considerations. At this level human rights are the overarching principles under which the government tries to operate. This would be the 'big P' policy area, and it may be the 'big P' policy of a state, for instance, to decide that in principle child abuse must not be tolerated.

- At the micro level, the system is about a particular child's right in a particular case. Here there is a need to know where the responsibility of the state starts and ends.

- At the meso level, containing the transition between those ideals, it is the level of law and regulation because then there are standards against which to judge the micro case. These would be the 'small p' policies that underpin this level of law and regulation.

The movement between the three levels is a process over time and it draws together a range of elements in the woven pattern that has been termed complementarity.

Alongside the distinctive features of the two fields, implementing human rights can be seen as an integral part of the government's public policy programme. 
Full advantage is not being taken, however, of some of the tools of the public policy field that could help inter-agency coordination on human rights issues. Later in the thesis in Section 5.3.2, there will be discussion on how the joined-up literature and coordinated stage agencies work from this field could be extremely helpful in this respect.

\subsection{Taking account of international and domestic human rights in policy making}

Having looked at these two fields brief mention is now made of the requirement for officials to take account of both international and domestic human rights in policy making. The Ministry of Justice guidelines on NZBORA for the public sector point out to officials in a section entitled 'International Scrutiny' in relation to reports to UN committees:

\footnotetext{
You should therefore be aware that, if your agency has developed policies or practices that appear to be inconsistent with these [human rights] standards, those practices will be subject to international scrutiny. You will also be asked to prepare a response to those questions (Ministry of Justice, 2004: 6).
}

NZBORA affirms New Zealand's obligations under the ICCPR, so both the Covenant and the Act need to be taken into account. ${ }^{55}$ But the requirements for policy advisers to take account of international human rights law runs far wider than the ICCPR because such a wide range of policies and practices will be subject to international scrutiny under various reporting requirements. Apart from individual treaty reporting systems, the scope of reporting-scrutiny has been significantly widened by the four-yearly UPR reporting requirement to the UN Human Rights Council. This has added a peer review system for all ratifying countries. For instance, 36 states commented on New Zealand's summary of its human rights situation in the first UPR report presented in Geneva in May 2009. ${ }^{56}$ This international scrutiny arguably goes well beyond other treaty body reporting. For policy advisers in New Zealand, this adds significantly to the duties to protect a Minister from embarrassment, both locally and internationally.

\footnotetext{
55 Other related guidance includes Crown Law Office (2005), a paper entitled 'The Judge Over Your Shoulder: A Guide to Judicial Review of Administrative Decisions'.

56 See www.mfat.govt.nz/Foreign-Relations/1-Global-Issues/Human-Rights/Universal-Periodic-Review/human-rights-review.php (accessed on 10 January 2010).
} 
The second more specific aspect of international scrutiny relates to the existence of an Optional Protocol mechanism for some treaties. At the time of the development of the UDHR in 1948 New Zealand exerted pressure to have a mechanism for individuals to appeal directly to the UN about infringements of their rights. In his speech to the UN General Assembly in December 1948, Colin Aikman said that this was a further method of ensuring implementation along with robust legally binding Covenant obligations. $\mathrm{He}$ asserted:

... there is a clear need for the establishment of satisfactory procedures and machinery for receiving and dealing with petitions. We ourselves believe that petitions should be entertained from individuals, groups, associations or states (Department of External Affairs 1948: 1).

Although this idea was dismissed at the time, it was eventually developed two decades later as the First Optional Protocol to the ICCPR (adopted by the UN in 1966), a complaints mechanism for individuals to petition the UN Human Rights Committee of that treaty on civil and political right violations. Optional Protocols are considered necessary because they help individuals seek justice when their claims have been denied in their domestic jurisdiction. New Zealand did not accede to this Optional Protocol until 1989. A Second ICCPR Optional Protocol on the abolition of the death penalty was also adopted by the UN General Assembly in 1989, and New Zealand was the first country to accede to that instrument in $1990 .{ }^{57}$ There is therefore a growing ability for individual citizens to make a direct complaint to the UN. The first case study (Baigent's Case) illustrates the effect this has had on the development of this country's domestic mechanisms of implementation.

\footnotetext{
57 Three other conventions now also have Optional Protocols: the Convention on the Elimination of All Forms of Discrimination against Women (CEDAW); the Convention on the Rights of the Child (UNCROC); and the Convention on the Rights of Persons with Disabilities (CRPD). Two other conventions have related systems in place: the Convention against Torture (CAT) enables individual communications to be made and for the committee to launch investigations into grave breaches; and the Convention on the Elimination of all Forms of Racial Discrimination (CERD) committee can receive individual communications and set up urgent action processes and warning notices if necessary. What is clearly missing is that individuals cannot directly petition the UN Committee on Economic, Social and Cultural Rights in relation to breaches of the ICESCR. This leaves the state's own reporting system as the primary method of pressure in cases of systemic breaches. However, given the mechanisms available for the other conventions there is building momentum for an Optional Protocol to the ICESCR. For the latest developments on this see www2.ohchr.org/english/issues/escr/intro.htm. Francioni and Conforti also raise two factors that can mean an individual citizen in a country might not have full recourse to remedies under international human rights treaties. The first is that many countries have not signed Optional Protocols to treaties, and it is these mechanisms that give individuals the right to make a complaint directly to the committee of some treaty bodies such as the ICCPR. The second is that even if these Optional Protocols have been signed, there is a 'full exhaustion of domestic remedies' clause which the authors believe can be used as a blocking mechanism by national courts (Francioni and Conforti 1997: 15). As well as individual citizens using the Optional Protocol route, there has also been a case of a class action under the ICCPR. The Mauritian Women Case (UNHRC Communication No. 35/1978) involved 19 Mauritian women who objected to newly enacted immigration laws on gender discrimination grounds. The laws caused loss of residence status for foreign husbands (but not foreign wives), and the UNHRC judged the legislation to be in breach of the ICCPR.
} 
Policy advisors working in this climate therefore need to be cognisant that New Zealand citizens are also potential actors in an international environment, particularly if domestic legislation offers insufficient protection of ratified treaty rights. This is not therefore just a story about the New Zealand human rights framework with its structures and legislation and placement alongside other jurisdictions. It is also about the placement of the New Zealand citizen in the context of their 'international' human rights (accessed through the Optional Protocol route) vs their 'domestic' human rights (accessed through the local courts) and about the efforts of the state sector to smooth out the inconsistencies between these two areas. The more inconsistencies there are, the less legal protection citizens have and the more open the government is to international criticism by the UN and other countries.

\subsection{Summary}

Complementarity represents a multi-layered weave between the dimensions of international-domestic and the process of implementation as it operates in each jurisdiction. For all the international commonality, it will be clear that the New Zealand human rights framework has evolved through a specific public policy context and thus will show some differences from even close historical and political comparators. Such differences will undoubtedly affect the treatment of human rights in/by the state sector. This specificity is important to bear in mind when noting continuities from historical antecedents relevant to New Zealand. For instance NZBORA has aspects that draw on the histories and resulting documents from the Magna Carta (1215) and the English Bill of Rights (1689). This history and the evolving relationship between the monarchy, Parliament, the courts and citizens affects current constitutional arrangements which in turn impact on the New Zealand human rights framework. Also, because all policy advisors increasingly work in an environment greatly affected by human rights in the domestic and international versions, it has been important to clarify in this chapter the relationship between the public policy and human rights fields. As noted, the human rights field itself has various facets as an advocacy movement, a comprehensive worldview, an area of scholarship, and a category of public policy. Having examined these contextual issues, Chapter 3 now turns to New Zealand's interaction with the international framework for human rights as it developed in the $20^{\text {th }}$ century. 


\section{CHAPTER 3: INTERNATIONAL FRAMEWORKS}

The concepts and contexts outlined in the previous chapters need now to be located in the international framework. New Zealand has always taken part of its identity from internal sources (its people) and part from external sources - meaning the recognition by neighbours and the rest of the international community that this is a distinct entity. The interplay between local and international has been present for many decades, and this chapter explores how the two spheres have become interwoven.

Especially from World War II onwards, this country contributed significantly to the formation of the UN and to the ambitious international human rights agenda. By the end of the $20^{\text {th }}$ century, New Zealand's own human rights landscape had been transformed by its acceptance that the framework thus created demanded the ratification and implementation of human rights treaties. This chapter therefore outlines the development of the ever-growing international human rights architecture since the mid1940s to show the background to New Zealand's human rights framework. This expansion included the development of the treaty reporting and ratifying processes that states adhere to. The UN has spawned both large internal institutional structures and processes, but also further limbs, such as regional mechanisms and national human rights institutions (NHRIs), deep inside the domestic architecture of ratifying nations. The chapter ends with a section on UN guidance to states about human rights and looks at four ways this is occurring. Finally the issues in this chapter relate to Phase One of the six phases outlined in Table 1 (see Section 1.4), which is marked by three key themes (international collaboration, structural development and international lawmaking), and these will be identified throughout this discussion.

\subsection{New Zealand at the UN: 1944-1948}

\subsubsection{Atlantic and UN Charters}

This period was a time of intense international collaboration, especially amongst the Allies in World War II. The international human rights architecture that was set up after 
the war was seeded from the Atlantic Charter signed in 1941 by Roosevelt and Churchill. Before the 1940s there was no systematic international framework for human rights (MFAT, 2008: 11). Various $19^{\text {th }}$ and early $20^{\text {th }}$ century treaties, mostly related to slavery and armed conflict, had attempted to address these issues which now come under the broad human rights umbrella. ${ }^{58}$ The Atlantic Charter was 'an early pointer to a new world order more oriented towards a rights-based system' (MFAT, 2008: 13). New Zealand had been involved in ILO work since before the war and it was from this standpoint that Prime Minister Peter Fraser was asked to contribute to British War Cabinet discussions about the Charter, especially in the area of labour standards and social security.

The fifth point of the Charter noted that nations should help to secure 'improved labour standards, economic advancement and social security' (Royal Institute, 1947: 10). Twenty-six countries (including New Zealand) then signed a UN Declaration in 1942, and the resulting Dumbarton Oaks draft of 1944 was an attempt by some countries to establish a UN Organisation (Templeton, 1995: 13). The declaration was in part about agreeing to 'preserve human rights and justice' in the countries of the signatories and 'in other lands' (Royal Institute, 1947: 11). New Zealand influenced the nascent international human rights environment in four ways between 1944 and 1948 as pressure from this country:

- altered wording in the Dumbarton Oaks draft

- affected the principles behind the UN Charter

- strengthened the overall position of the Economic and Social Council (ECOSOC) at the UN and increased its human rights mandate, and

- upheld the need to develop a legally binding covenant that would hold ratifying countries accountable. ${ }^{59}$

\footnotetext{
58 These included the Convention to Suppress the Slave Trade and Slavery 1926, the Geneva Conventions of 1864 and 1906, and the Hague Conventions of 1899 and 1907. After World War I the founding of the International Committee of the Red Cross (1876), and the League of Nations and the International Labour Organisation (both in 1919) were key precursors to the eventual establishment of the UN (MFAT, 2008: 11).

59 It should be noted that only one covenant was envisaged, but because of lack of agreement in drafting the content of a single document work started on two separate instruments in 1951 - the first civil and political (ICCPR) and the second economic, social and cultural (ICESCR). It then took until 1966 for the UN to adopt the two covenants, partly because of the rapidly increasing
} 
A fifth pressure from New Zealand - to have a mechanism for individuals to appeal directly to the UN - was dismissed at the time. However, as noted already the idea was eventually developed as the First Optional Protocol to the ICCPR in 1966, the complaints mechanism for individuals to petition the UK Human Rights Committee of that covenant on civil and political right violations.

In regards to the first influence, the 1944 Dumbarton Oaks draft was not heavily focused on human rights and New Zealand, Australia and other smaller powers called for a greater emphasis on this area. The following year the UN Conference on International Organisation (UNCIO) was held in San Francisco to draft the UN Charter, with 50 nations meeting to discuss the proposal. This Charter eventually mentioned human rights three times.

The first instance in the Preamble asserts that:

We the people of the United Nations ... reaffirm faith in fundamental human rights, in the dignity and worth of the human person, in the equal rights of men and women and of nations large and small.

The second instance relates to the chapter on Principles in the UN Charter, and it is here that New Zealand exerted its second influence. The aim of this Charter was similar to the Atlantic Charter - to maintain international peace and security and promote the economic and social advancement of all peoples - and human rights were seen as a key part of this (Royal Institute, 1947: 149). During the development phase of the UDHR in the immediate post-war period Prime Minister Fraser worked hard to ensure human rights were taken seriously by the Great Powers. He pressed for traditional civil and political rights to be inserted into the Declaration and, despite much opposition, economic, social and cultural rights. At the 1945 UNCIO conference to draft the UN Charter, New Zealand, Australia and other smaller powers called for a greater emphasis on human rights. Although not in the first draft wording, the Charter eventually mentioned human rights three times and this was in large part due to pressure from Prime Minister Fraser who insisted on this inclusion. In the New Zealand report on the UNCIO he stated that:

... the Conference succeeded in generally widening the scope of the Organisation to include not only questions of peace and security, but those relating also to human rights

membership of the UN and Cold War tensions. For more details about this see Helen Fawthorpe (1995: 98-99) and MFAT (2003: 15). 
(Department of External Affairs, 1945: 14).

More specifically he was concerned that governments should be responsible for economic, social and cultural rights as well as civil and political and his pressure in this area was pivotal. In the same report when talking about the actual structure of the UN he stated:

By elevating the proposed Economic and Social Council to the status of one of the "principal organs" of the United Nations, by broadening its scope of activity, and by setting in front of every nation certain positive objectives, the Charter recognises the very great bearing that economic and social conditions have on the peace, security and progress of the world (Department of External Affairs, 1945: 14).

The rights-based approach seeded in the Atlantic Charter was easily married to other critical international issues of the time. A fundamental triangle for the new world order now emerged - collective security/economic growth/human rights - which Fraser understood and articulated very well. Human rights, as a key part of this triangle, were now seen to need special protection. As part of the pressure to increase the status of human rights in the UN Charter the New Zealand delegation suggested that a new paragraph be added to the chapter on Principles:

All members of the Organisation undertake to preserve, protect and promote human rights and fundamental freedoms, and in particular the rights of freedom from want, freedom from fear, freedom of speech and freedom of worship (Department of External Affairs, 1945: 23).

These words were not eventually used, but the chapter on Principles did contain a new paragraph:

To achieve international cooperation in solving international problems of an economic, social, cultural or humanitarian character, and in promoting and encouraging respect for human rights and for fundamental freedoms for all without distinction as to race, sex, language or religion.

The third instance occurred in Article 55 of the Charter:

... the United Nations shall promote ... universal respect for, and observance of, human rights and fundamental freedoms for all without distinction as to race, sex, language or religion.

Malcolm Templeton noted that the New Zealand delegation was aware of and concerned about the tensions between the provisions of Article 2 of the Charter (the principle of non-intervention in the domestic affairs of states) and Article 55 (where states pledge to promote human rights for all without discrimination) (Templeton, 1995: 17). Helen Fawthorpe also commented that the Article 2 vs Article 55 provisions had created problems when this country was developing its policy on apartheid in South 
Africa. She stated that eventually:

... New Zealand came to accept the analysis that the Charter was intended to enable UN members to take action on blatant human rights abuses in individual countries without this being construed as a breach of the principle of non-intervention (Fawthorpe, 1995: 103).

In terms of the third influence, during the UN Charter discussions the New Zealand delegation (along with several other countries) also pressed for a more robust ECOSOC. This included giving it clear responsibility for international human rights under Articles 62 and 68. This was in contrast to the weaker role for the Council that had been proposed by the great powers during the Dumbarton Oaks discussions. The Charter eventually elevated ECOSOC to one of the five principal organs of the UN on an equal footing with the UN General Assembly, the Security Council, the Trusteeship Council, the ICJ and the Secretariat (Department of External Affairs, 1945: 33, 51). Behind this pressure was Prime Minister Fraser's concern that governments should be responsible for these rights as well as civil and political and he articulated the clear linkage between the provision of second generation rights and international peace and security (Department of External Affairs, 1945: 14). This pressure began a long-standing interest for New Zealand in the implementation of these types of rights, and raising their status 70 years later in the 2000s is the topic of Chapter 6.

\subsubsection{UDHR, ICCPR and ICESCR}

The UN Charter also mandated the establishment of the UN Commission on Human Rights which was asked to draft an International Bill of Rights containing three parts: a declaration of human rights to be adopted by a resolution of the UN General Assembly; an international Covenant on human rights binding on States Parties; and measures for their implementation (MFAT, 2008: 13). By 1948 the UDHR had been adopted. Prime Minister Fraser set up a Human Rights Committee back in New Zealand to assess the draft declaration and he led the 1948 delegation to the three-month long General Assembly UDHR debates in Paris. Colin Aikman, the New Zealand diplomat who was part of the delegation, reiterated Fraser's UN Charter concern about the importance of economic and social rights. In a speech to the UN General Assembly on 9 December 1948 he asserted that:

... we regard with particular satisfaction the place which is given in the Declaration to social and economic rights. Experience in New Zealand has taught us that the assertion of the right of personal freedom is incomplete unless it is related to the social and economic rights of the common man.... only with social security in its widest 
sense can the individual reach his full stature. ... These social and economic rights can give the individual and normal conditions of life which make for the larger freedom. And in New Zealand we accept that it is a function of government to promote their realisation (Department of External Affairs, 1948: 1).

This very small team of the committee members and the delegation itself showed the relatively shallow public policy base from which New Zealand, having a big voice for a small country, influenced the international framework. Today there would be much more support and many advisors across multiple agencies behind any such delegation. It is also a good early example of the proactive approach that this country has taken in the human rights area.

The final fourth influence was about developing a legally binding covenant. Richard Wild noted that the UDHR debate centred on the worth of the document and whether it was practical to have legal sanctions. The New Zealand position was that the Declaration should:

\begin{abstract}
... state the philosophical basis of human rights and fundamental freedoms, define the essence of each, and state, in a form comprehensible to the peoples of the world, the objectives of the United Nations in the field of human rights ... [it] cannot in itself impose any legal obligations ... although it may ... provide a guide to the interpretation of the United Nations Charter (Wild, 1968: 5).
\end{abstract}

New Zealand had, however, originally argued for a legally binding UDHR but after discussions the UN General Assembly made the Declaration a resolution with the intention that the proposed covenant would be binding (MFAT, 2008: 13; Fawthorpe, 1995: 98). Colin Aikman reinforced this in his December 1948 speech stating that 'legally binding international conventions are ... essential' over and above the Declaration which he saw as a statement of principles with moral force only (Department of External Affairs, 1948: 1). During the UDHR discussions New Zealand had sponsored Resolution E of the Report of the Third Committee of the UN General Assembly, stressing that the Commission on Human Rights needed to urgently draft a covenant with forceful measures for implementation. The UN General Assembly adopted both the ICCPR and ICESCR nearly 20 years later in 1966, along with procedures for measuring compliance, and these were eventually ratified by New Zealand in 1978. The two covenants are legal treaties and states need to make formal reservations at the time of ratification if their domestic law does not comply with their obligations.

The first four influences during the 1940s helped ensure a strong human rights regime at the UN, both structurally and philosophically. At the time of the $50^{\text {th }}$ 
anniversary of the UDHR Helen Fawthorpe noted that 'New Zealand played a significant part in improving the text' of the UN Charter (Fawthorpe, 1995: 97). In 2000, the Re-evaluation of the Human Rights Protections in New Zealand report stated that during UN Charter and UDHR drafting 'New Zealand played a leading role in the development of a new branch of international law' (Ministry of Justice, 2000a: 20).

The fifth influence did not come to fruition for another four decades with the development of the First Optional Protocol to the ICCPR in 1966. Colin Aikman's December 1948 speech on the UDHR urged that individuals should have the ability to petition the UN directly (Department of External Affairs, 1948: 1). One result of the marriage of international and domestic human rights standards - the Optional Protocol to the ICCPR - has also linked the UN-New Zealand positions very closely. As Helen Fawthorpe noted, the Court of Appeal suggested in 1994:

\footnotetext{
... since New Zealand's accession to the Optional Protocol, the UN Human Rights Committee is in a sense part of this country's judicial structure, in that individuals subject to New Zealand jurisdiction have direct rights of recourse to it (Fawthorpe, 1995: 101). ${ }^{60}$
}

However, the New Zealand courts have preferred that individuals find redress and remedies through the domestic courts without needing this route (see Section 8.1.1 for a fuller discussion).

\subsection{The international human rights system}

This section sets out the various features of the international human rights system. Its base is the UN, but through treaty-making, ratification, reporting, the development of regional mechanisms and NHRIs, and efforts at good governance, its effect is widespread throughout the domestic sphere of ratifying countries. This section also describes a period of intense structural development and international law-making which are Phase One themes. 


\subsubsection{Bi-fold organisational/legislative international framework}

From the above it can be seen that foundational pillars of the emerging international human rights framework were laid during the 1940s. The Atlantic and UN Charters had led to the development of the UN in 1945. The main body dealing with human rights matters, the UN Commission on Human Rights, had been set up in 1946 under ECOSOC and the UDHR was adopted by 50 countries in 1948. All five organs of the UN - Secretariat, UN General Assembly, ECOSOC, the Security Council and the ICJ were given some human rights role whether direct or indirect. ${ }^{61}$

A Sub-Commission on the Promotion and Protection of Human Rights was set up in 1947. It has established a number of working groups, e.g. on slavery or indigenous populations, and has rapporteurs working in specialised areas (Shaw, 2003: 285-286). The UN General Assembly is directly mandated under Article 13 of the UN Charter to promote the realisation of human rights and also adopts human rights treaties and passes resolutions. The Third Committee (Social, Humanitarian and Cultural) of the UN General Assembly has specific responsibility for human rights matters. The Security Council (as executive organ) and the ICJ (as judicial organ) have no formal mandate under the Charter in this area. However, the Security Council's role is to maintain peace and security and humanitarian concerns are often related. Similarly, the ICJ has ruled on human rights and humanitarian issues such as apartheid and genocide (MFAT, 2008: 28). In 2008, Matthew Palmer articulated New Zealand's commitment to the international human rights system:

... for a small state like New Zealand, economically dependent on international trade and historically committed to international human rights, it makes political and economic sense to adhere to the rule of international law and to independent judgments of its content. New Zealand argued that ICJ jurisdiction should be compulsory when it was being established and New Zealand has always accepted the court's jurisdiction as binding. This view of international law is so entrenched I believe it has become a feature of New Zealand's own constitution (Palmer, 2008: 154).

After a long interlude of five decades three further developments strengthened the UN human rights framework. The first, the post of UN High Commissioner for Human Rights (UNCHR), was established as an outcome of the 1993 Vienna World Conference

\footnotetext{
61 ECOSOC's mandate in this area is wide ranging: overseeing the Commission on Human Rights, drafting conventions, organising international conferences, obtaining reports from States Parties, and appointing special rapporteurs who focus on individual country violations or wider themes such as torture or the sale of children. Having the main responsibility for human rights at the UN, the Commission is further able to draft human rights instruments, investigate claims about violations and liaise with major international NGOs in the area (MFAT 2008: 29).
} 
on Human Rights with a view to improved coordinated management of the UN's efforts in this area. ${ }^{62}$ The second was the establishment of the International Criminal Court (ICC) in 1998. It is a permanent independent international court able to try individuals for some serious issues such as war crimes, crimes against humanity and genocide. ${ }^{63}$ The third development was that the UN Human Rights Council was established in 2006. This is an inter-governmental body within the UN comprising 47 states responsible for the promotion and protection of human rights. ${ }^{64}$

As can be seen from the above, over a 60 -year period a UN human rights framework has therefore been set up based on a number of foundations: a unifying leadership (UNCHR); substantial powers given to the Commission on Human Rights; a reporting and violations investigation process; a standards-setting ability through drafting conventions and instruments; a research and educative capacity; an international criminal court which can try certain human rights abuses; and a Human Rights Council more able to deal adequately with violations. The creation of these institutional structures solidified what this research terms the first 'organisational level' of the emergent international human rights architecture (see Table 2).

What this research terms a second 'international law level' began developing in parallel with the organisational level and resulted in the creation of several major human rights legal instruments. The primary instruments are those which form the International Bill of Human Rights (the UDHR, ICCPR and ICESCR). From the mid-1960s to the late 1980s four major conventions were also established on key single-issue topics: the Convention on the Elimination of All Forms of Racial Discrimination 1965 (CERD); the Convention on the Elimination of All Forms of Discrimination Against Women 1968 (CEDAW); the Convention on the Rights of the Child 1989 (UNCROC); and the

\footnotetext{
62 The Commissioner is directly responsible to the UN Secretary General but works closely with the UN General Assembly, ECOSOC and the Commission on Human Rights. The UN Secretariat has direct responsibility for the Office of the High Commissioner for Human Rights (OHCHR), which supports the Commissioner and carries out research, education and fieldwork (Shaw, 2003: 34).

63 The court contains 18 judges 'representative of all regions and legal systems'. The ICC's jurisdiction is 'complementary' to national court systems and it only takes over as a 'court of last resort' when the appropriate state is 'unwilling or unable' to investigate an issue (NZ House of Representatives, 2005: 43). Many human rights abuses occur during armed conflicts and the establishment of the ICC was an important step in ensuring these cases are brought to justice.

64 The main purpose of the UN Human Rights Council is to address situations of human rights violations and make recommendations on them. In June 2007 the Council adopted an Institution Building Package which included: the new UPR mechanism, which assesses human rights in the 192 member states of the UN over and above the periodic reporting for the core treaties; a new 'think tank' Advisory Committee which provides advice on thematic human rights issues; and a revised Complaints Procedure mechanism so that individuals and organisations can raise issues directly with the Council. See www2.ohchr.org/english/bodies/hrcouncil for more information on the Council.
} 
Convention Against Torture and Other Cruel, Inhuman or Degrading Treatment 1984 (CAT). The next one, the Convention on the Rights of Persons with Disabilities (CRPD), was adopted by the UN over 20 years later in 2007. New Zealand has ratified all of these covenants and conventions after extensive reviews of law, policy and practice. ${ }^{65}$ It should be noted that the growing domestic human rights architecture in New Zealand has been influenced by UN comment through the cyclical reporting process for the core treaties. Ratifying countries are required to submit an initial report for the core treaties (and then a five-yearly periodic report), and the UPR process is in addition to this. The Concluding Observations, as the UN's feedback to states, give a historical picture over time about the UN's views on New Zealand's compliance or not with human rights obligations and help states to prepare future reports. ${ }^{66}$

The UDHR, the two covenants and the five conventions are the eight core international human rights instruments. Each covenant or convention has its own treaty monitoring committee, for example the UN Human Rights Committee oversees the ICCPR and the UN Committee Against Torture is responsible for CAT. Through regular periodic reporting these committees try to ensure ratifying states comply with the obligations set out under each treaty. During the report preparation process government agencies are given a concrete opportunity to consider the relevant instruments as a yardstick for their policies and practices. There is also a role for NGOs, as they are consulted during the preparation and are encouraged to submit parallel or shadow or alternative reports. The $\mathrm{UN}$ treaty body system is seen to be 'a cornerstone of the international human rights

\footnotetext{
65 Apart from the ratified covenants and conventions mentioned above, the UN sometimes develops 'soft law'. The implementation of ratified international law into domestic legislation is hard law or internationally binding law. It is useful at this point to briefly raise the distinction between hard and soft law. The latter includes declarations of the UN General Assembly or minimum standards in an area which states are invited to comply with. Examples are the Declaration on the Rights of Indigenous Peoples or the UN Standard Minimum Rules for the Treatment of Prisoners. These can operate perhaps more on a moral basis, as countries do not want to be seen in breach of them. It is therefore possible to talk about hard law and soft standards: the first legally binding, and the second at most morally binding although sometimes carrying much weight. Soft law is therefore still important in the international human rights compliance framework. In New Zealand implementation and public policy issues can arise out of minimum standards because the Government tries hard to adhere to them. Again, this is a well-researched area and is not a part of the scope of this thesis. Victor Conde's definition of soft law is: 'A term describing a doctrine of international law that describes the legal status of certain human rights related declarations, resolutions, guidelines, and basic principles. They are created by international, intergovernmental organisations, such as the UN, as nonbinding norms, setting forth nonobligatory but highly recommended standards of state conduct that should be followed. It is "soft" law because it is not legally binding, as is "hard law" , (Conde, 2004: 242). For more discussion on the distinction between the two types of law and the way they are used by different actors (state, nonstate) see Abbott and Snidal (2000), and for a discussion on the transformation of soft law into hard law (as sometimes happens) see Chinkin (1989).

66 See Section 5.6 for more information on Concluding Observations.
} 
machinery' (NZ House of Representatives, 2005: 46). Independent experts sit on the treaty bodies and have a number of roles. ${ }^{67}$

The UN-New Zealand interplay has been well documented in the ICCPR and ICESCR New Zealand state party reports and Concluding Observations over the last three decades. $^{68}$ They form an historical account of this country's compliance and uptake of rights into law, policy and practice. There has been a robust debate between the New Zealand delegations and the committees for each covenant during this period. Related to this area is the literature surrounding treaty body reporting. Frauke Lisa Seidensticker (2005), Deputy Director of the German Institute for Human Rights, has looked at both the strengths and weaknesses of this system in an analysis of state reporting by human rights treaty bodies. Part of what hinders the effective human rights implementation at the state level is that huge problems have occurred over time with the treaty body reporting system. Much has been written about the need for treaty body reform by authors such as Alston and Crawford (2000). This research will not explore this area except to mention that the major areas of concern are: some state parties are slow to report and do not meet deadlines, sometimes because of inadequate resources to satisfactorily file a report; the large backlog of reports waiting to be assessed by committees who are also under-resourced; and the lack of follow-up of issues raised by committees (Seidensticker, 2005: 9).

\subsubsection{Towards a tri-fold international framework: guidance level}

A bi-fold organisation/legislative framework has been outlined, and it is now possible to see that a tri-fold framework is also developing because of the emerging UN guidance level. Now that the first two aspects have settled down, and several decades have passed since the establishment of the UN organisation and resulting international law, it has become clear that simply having the treaty body system in place does not necessarily improve human rights in all countries i.e. there is no simple equation of 'treaty ratification $=$ improved human rights'. Implementing international treaty rights is difficult for developed nations such as New Zealand, let alone developing states that

67 These roles include: 'monitoring the implementation of the core human rights treaties; raising awareness of violations of these treaties and human rights norms; interpreting the rights and obligations in the treaties and promoting a greater understanding of these; encouraging better implementation and compliance through advice to states parties and identifying needs for additional technical assistance' (NZ House of Representatives, 2005: 46).

68 New Zealand's state party reports can be found on the OHCHR website (www.ohchr.org). 
have far less resources, and possibly more corruption and less respect for the rule of law. This third guidance level has become larger and larger as the UN attempts to steer states in a direction that is more human rights compliant. Four of the methods that the UN is using to guide states more clearly are now discussed below: harmonised guidelines (including requiring states to submit Core Documents); encouraging states to set up appropriate institutional frameworks; national human rights protection systems; and good governance requirements.

In 2008 the UN distributed harmonised guidelines to states on how to report on the major treaties (UN, 2008). This includes the development of a Core Document for each state which is submitted to each treaty body, along with the usual treaty-specific report to the relevant committee, and this document is seen as a way of reducing duplication of material to a number of committees. ${ }^{69}$ The Core Document sets out information about the demographics, geography, legal system and politics of each country (Seidensticker, 2005: 7). As each treaty committee should now be applying a consistent approach, the treaty monitoring system should also be more effective. Also as part of the new coordinated approach to preparing reports for treaty bodies the UN has urged states to consider setting up 'an appropriate institutional framework' for their preparation - this could be an inter-ministerial drafting committee and/or delegated officials within relevant government departments (UN, 2008: 5). In New Zealand MFAT has oversight over the treaty body reporting process with assistance in particular from the Ministry of Justice and the Crown Law Office. The UN expect that the framework within which human rights are promoted within each state should penetrate several levels: national and regional parliaments and assemblies; NHRIs; government officials and other professionals; human rights education programmes; mass media; NGOs; and overseas development assistance programmes (UN, 2008: 12).

The Commonwealth Secretariat had also produced a report on best practice for NHRIs which highlighted their important involvement in the reporting process, given their role in monitoring state compliance with international obligations (Commonwealth Secretariat, 2001: 30). The report stated the need for each NHRI to have a 'cooperative relationship with the international treaty machinery' and that national reports need to be prepared by the executive taking into consideration comments from the NHRI 
(Commonwealth Secretariat, 2001: 30). In New Zealand this function is carried out by the HRC (the NHRI), who have the opportunity to comment on treaty reports before they are sent to the UN. Apart from trying to streamline the reporting process the UN has also tried to give more guidance about how to protect human rights within states. In 2003 the UN Economic and Social Council identified key features of national human rights protection systems:

- Democracy: democratic institutions and processes that enable participation

- The rule of law: including the incorporation of international human rights standards in the national Constitution and laws

- An independent and corruption-free judiciary: that applies international human rights standards and jurisprudence

- Good governance: effective structures of government at central, regional and local levels that recognise, respect and apply human rights standards

- Specialised human rights institutions and accountability mechanisms

- Human rights information and education

- An active civil society: citizens who engage, organise and participate

- A focus on the most vulnerable parts of the population (UN Economic and Social Council, 2003: 403).

One of the most important features is seen to be 'good governance'. A definition of this is given below, and the key point here is that it is identified as a 'right' of the citizen against the state. ${ }^{70}$ In 2007 the OHCHR published Good Governance Practices for the Protection of Human Rights to help states close the gap between human rights standards and their actual implementation, which is what this research is about. In other words, this was about putting the theory of being a compliant human right state into practice in a realistic way. The OHCHR has recognised that unless good governance practices are in place, it is difficult for human rights to be fully realised and they define it as 'the exercise of authority through political and institutional processes that are transparent and accountable, and encourage public participation' (OHCHR, 2007: 2). It can be carried out through a range of mechanisms from laws, policies and programmes to

70 Conde identifies good governance as: 'An evolving principle that roughly means that the inherent dignity of individuals and their collective holding of human rights entitle them to "good governance", within state societies, meaning they deserve a government characterized by the rule of law, having a democratical political basis (elected by plebiscite), and responsive to the people. Good governance also includes adequately structured state institutions with efficiency and transparency of institutions and procedures and respect by all governmental authorities for the human rights of all persons within the territory of the state; with access by individuals to means of redress for violations of law; accountablity of public officials for misconduct, malfeasance, and human rights violations; and a public sector with an active and free civil society' (Conde, 2004: 102). 
'political, managerial and administrative processes' (OHCHR, 2007: 1-2). In this model human rights are linked with good governance in four ways which will be discussed below: (1) strengthening democratic institutions; (2) improving delivery of state services; (3) the rule of law; and (4) combating corruption.

Democratic institutions are strengthened by involving the public in policy and lawmaking and ensuring that elected officials are accountable. It also means that a wide range of groups are represented, including disadvantaged groups, in discussions about rights. The four strengthening planks suggested by the OHCHR are: democratic elections, transparency, accountability, inclusion and participation. It is hoped that this inclusive approach will result in better laws and policies (OHCHR, 2007: 9). State service delivery is improved through better education, health and social welfare services. The OHCHR believed these services need to be 'available, accessible and culturally acceptable' and protect the rights of vulnerable groups (OHCHR, 2007: 29). Strengthening the accountability of public officials is key to upholding the rule of law. This accountability can be carried out through:

$$
\begin{aligned}
& \ldots \text { the adoption of sound legislation, the establishment of institutional checks and } \\
& \text { balances, the establishment of systems providing redress to victims of violations, and } \\
& \text { the training of state officials on human rights and good governance (OHCHR, 2007: 6). }
\end{aligned}
$$

Officials also need to be human rights trained in order to understand the rights they are upholding. Other ways of strengthening the rule of law include: the right to free legal assistance, legal and policy reforms to ensure international human rights obligations are met, and the reform of state justice systems (OHCHR, 2007: 45)

The OHCHR also stated it is important that the public has access to rights-related information in order for transparency to occur, so a strong public education effort is vital in tandem with moves to hold public officials accountable (OHCHR, 2007: 5). They also encouraged a collaborative effort among a wide range of actors to improve good governance practices: national and local governments, the media, non-state actors, NGOs and civil society. Again this illustrates the Phase One theme of collaboration. The OHCHR further believed that corruption has a myriad of effects: bribery ensures services are given to those with money instead of the most vulnerable; it undermines democratic institutions and public participation; and citizens cannot easily get their civil and political rights upheld when all levels of the judicial system - 'judges, lawyers, prosecutors, police officers, investigators and auditors' - are corrupt (OHCHR, 2007: 
59). In relation to anti-corruption, Transparency International is an international civil society organisation with 90 national chapters (one exists in New Zealand). Their aim is to 'bring together relevant players from government, civil society, business and the media to promote transparency in elections, in public administration, in procurement and in business'. ${ }^{71}$ The organisation produces an annual Corruption Perceptions Index on their website measuring how public sector corruption is perceived in 180 states. On the 2009 index, New Zealand is perceived as the least corrupt with a score of 1, and Somalia was considered the most corrupt at $180 .{ }^{72}$ These strategies of transparency and accountability help ensure state officials are upholding human rights instead of violating or curtailing them.

The OHCHR's 2007 guidelines are therefore not just about 'good governance'; they are also about 'good guidance', the third level suggested in Table 2 which follows. Sending countries strong messages about what constitutes a human rights compliant state gives them better indicators to aim for and helps them on the path towards robust human rights governance. The tri-fold structure of Figure 2 relates to the macro (or big $\mathrm{P}$ policy) level discussed in Section 2.2. Here the international framework (with its organisations, charters, instruments and guidance) clearly sets out the principles underpinning the human rights endeavour. Governments are also encouraged to prioritise resources to implement human rights standards. In Chapter 5.8.1, at the end of the discussion on embedding a human rights approach into the state sector, it is suggested that a four-fold domestic human rights framework is emerging.

The discussion now turns to regional mechanisms and NHRIs, and both involve the Phase One themes of structural development, collaboration and law-making. Lawmaking occurs at the regional human rights level because there are enforceable treaties such as regional conventions and charters.

\footnotetext{
71 See www.transparency.org.

72 Other countries on the spectrum include: Australia and Canada (8), Germany (14), the UK (17), the USA (18), France (24), Spain (32), South Africa (55), Cuba (61), Greece (71), Brazil (75), China (79), India and Thailand (84), Vanuatu (95), Tonga and Zambia (99), Argentina (106), Egypt, Indonesia and Kiribati (111), Lebanon and Libya (130), Russia and Zimbabwe (146), Papua New Guinea (154), Haiti and Iran (168), and the five most perceived as corrupt just below Somalia - Chad (175), Iraq and Sudan (176), Myanmar (178) and Afghanistan (179). This issue is so large that the UN adopted a Convention Against Corruption in 2003.
} 
Table 2. Tri-fold international human rights framework

UN PRECURSORS

International Committee Red Cross 1876

League of Nations 1919

International Labour Organisation (ILO) 1919

1 ORGANISATIONAL LEVEL

ATLANTIC CHARTER 1941

$\downarrow$

UN DECLARATION 1942

DUMBARTON OAKS DRAFT 1944

$\downarrow$

UN ORGANISATION 1945

$\downarrow$

UN CHARTER 1945

$\downarrow$

Mandated five organs of UN

(UN Secretariat, UNGA, ECOSOC, Security Council, ICJ)

2 INTERNATIONAL LAW LEVEL

Eight core international human rights instruments:

Universal Declaration of Human Rights (1948)

International Covenant on Civil and Political Rights (1976)

International Covenant on Economic, Social and Cultural Rights (1976)

UN Convention on the Elimination of Racial Discrimination (1969)

UN Convention on the Elimination of All Forms of Discrimination Against Women (1981)

UN Convention on the Rights of the Child (1990)

UN Convention Against Torture (1987)

UN Convention on the Rights of Persons with Disabilities (2008)

\section{GUIDANCE LEVEL}

UN harmonised guidelines

Appropriate state-level institutional framework initiative

National human rights protection systems

Good governance requirements 


\subsection{Regional and national human rights instruments and mechanisms}

Regional mechanisms and instruments have been most highly developed in four parts of the world - Europe, ${ }^{73}$ Africa, ${ }^{74}$ the Americas ${ }^{75}$ and the Middle East. ${ }^{76}$ South-East Asia is improving in this respect, ${ }^{77}$ but there is nothing available as yet for this region (the Asia-Pacific). These mechanisms are key intermediary human rights protection points between the international UN system and the domestic human rights framework. There can be four levels involved: a regional body (such as the Council of Europe or African Union), a regional commission (such as the Inter-American Commission on Human Rights), a regional charter or convention (such as the European Convention on Human Rights), and a regional court (such as the European Court of Human Rights). If there is a regional court, individuals can get redress through this once they have exhausted domestic remedies. In effect, this is similar to the UN Optional Protocol route at an intermediary regional level. $^{78}$

\footnotetext{
73 Europe has the most developed system of regional protection, probably because the Council of Europe was established in 1950 only two years after the development of the UDHR. There are two inter-related strands to the European set-up. One is the Council with 47 member states, which oversees both the European Court of Human Rights and the implementation of the enforceable regional treaty, the European Convention on Human Rights (1950), which mainly protects civil and political rights. A further European Social Charter was set up in 1965 to protect economic, social and cultural rights (MFAT, 2008: 60). Another strand of human rights protection is related to the European Union (EU) and there is a close association between the Council of Europe as a regional human rights mechanism and the EU. The 27 member states have to be fully or nearly fully compliant with the European Convention on Human Rights before they can join the EU.

74 The African framework is based on the African Charter of Human and Peoples' Rights 1981. It contains first and second generation rights and 'created' the African Commission on Human and Peoples Rights (OHCHR, 2003: 72). This Commission operates under the equivalent of the Council of Europe, the African Union of 53 states. The African Court on Human and Peoples Rights 2004 has yet to hear a case and is possibly merging with the similar African Court of Justice.

75 In the Americas the Organisation of American States is the umbrella organisation at the same level as the Council of Europe. Out of this has developed the Inter-American Commission on Human Rights. Like the European system there is a court and a charter: the Inter-American Court of Human Rights and an American Convention on Human Rights 1969. As the Convention rights are first generation, an Additional Protocol to the American Convention on Human Rights was adopted in 1988 covering economic, social and cultural rights (OHCHR, 2003: 80).

76 In the Middle East, The League of Arab States has been in existence since 1945, making it the oldest existing regional body in the Middle East. A Human Rights Committee which comes under the umbrella of the League has been established, and an Arab Charter on Human Rights developed (OHCHR, 2003: 78). So far, however, no regional court has been established.

77 The South-East Asia region is now closer to having a human rights commission. National working groups from ASEAN (Association of South East Asian Nations) states have formed The Working Group for an ASEAN Human Rights Mechanism and this group is working towards developing a declaration of principles and a regional commission and court. The 10 countries involved are: Brunei Darussalam, Cambodia, Indonesia, Lao PDR, Malaysia, Myanmar, Philippines, Singapore, Thailand and Vietnam. See www.aseanhrmech.org for more information.

78 For a full discussion of the European, Inter-American, African and Arab regional mechanism systems see O'Brien (2001: Chapter 16).
} 
Gerd Oberleitner is a commentator on the large number of international, regional and NHRIs that have spawned since World War II. His comprehensive review of these institutions examined their rise and efforts by the UN since about 1997 to mainstream human rights into its organs and bureaucracy. As an international law and international relations specialist he has been described as a 'biographer' of human rights institutions, which suggests they have each taken on their own personality and life (Oberleitner, 2007: x). He also noted that global human rights institutions combine with regional human rights institutions, and they experience similar 'failures and achievements' (Oberleitner, 2007: 177). It is suggested in this thesis that NHRIs could also experience similar failures and achievements as they attempt to act as intermediary bodies between the UN and their own country. Not only this, whole domestic human rights frameworks can experience growth, then fragmentation and re-integration phases, and this research shows that this pattern has occurred in New Zealand. His other view is that global human rights institutions are an important bridge in the gap between vision and reality. That is:

They allow the move from the acknowledgement of values to their realization on the international level: agreeing on community norms, casting them in legal form, and inventing tools, mechanisms and instruments. ... Global human rights institutions can transform ideas into law, and law into change, in a way that is less haphazard and unpredictable than the actions of states (Oberleitner, 2007: 189, 190).

According to the OHCHR the major treaties for Europe, Africa and the Americas: 'have contributed to important changes in the laws of many countries ... and this case-law constitutes an important source of information and guidance for judges and lawyers' (OHCHR, 2003: 111). Noticeably there is no regional human rights mechanism that New Zealand and Australia are able to join at present. New Zealand has had an NHRI since 1977 and was one of the first countries to set up this national mechanism.

\subsection{National Human Rights Institutions (NHRIs)}

NHRIs are the bodies which monitor and protect human rights in various countries and can vary in name: 'human rights commissions and consultative councils to human rights ombudsmen, public defenders and people's protectors' (Pohjolainen, 2006: 1). However, as pointed out by Danish researcher on NHRIs, Anna-Elina Pohjolainen, they share common features because they are: 
human rights standards by acting as "guardians", "experts" and "teachers of human rights" (Pohjolainen, 2006: 1).

Most of these institutions are established via human rights legislation or a constitution and are considered by the Commonwealth Secretariat report on NHRI best practice to 'play a role complementary to that of the courts' (Commonwealth Secretariat, 2001: 10, 29). The report also noted that NHRIs are more likely to thrive in democracies and where 'there is a high degree of human rights literacy' (Commonwealth Secretariat, 2001: 39), and this literacy is important for robust human rights governance.

The concept of NHRIs was most firmly developed at the first International Workshop on National Institutions for the Promotion and Protection of Human Rights held in Paris in 1991. The principles relating to the status of NHRIs became known as 'the Paris Principles' and members need to be compliant with them and can seek 'A' status accreditation. This highly organised network also illustrates the Phase One collaboration theme. The NHRIs work closely with the OHCHR which noted that:

\section{Paris Principles compliant NHRIs stand out as partners that are central to national human rights protection systems and are important counterparts for the OHCHR. They can play a crucial role in promoting and monitoring the effective implementation of international human rights standards at the national level; a role which is increasingly recognized by the international community. ${ }^{79}$}

Commenting on the effectiveness of NHRIs Pohjolainen also suggested that: 'It is quite extraordinary that one institutional model - albeit a flexible one - has reached such prominence both on the international human rights agenda and in the domestic structure of states' (Pohjolainen, 2006: 118). However, at a 2009 Australian and New Zealand Society of International Law conference, commentators on a session on 'Regional and National Human Rights Protection: Creating a New Model in the Pacific' noted that Pacific states may well prefer to use other models that do not involve the Paris Principles (Renshaw et al, 2009). That is, they may find a system which is more culturally appropriate instead of trying to make the Paris Principles work as a 'one size fits all' template.

The NHRIs have formed regional bodies of which there are four: African National Human Rights Institutions; Asia Pacific Forum (APF) of National Human Rights Institutions; European Group of National Institutions; and the Network of National Institutions in the Americas. It may well be that over time these bodies form their own 
NHRI models because of their region-specific requirements and culturally different ways of approaching this. The Commonwealth Secretariat report noted that NHRIs are in a unique local position 'to monitor the human rights performance of governments' (Commonwealth Secretariat, 2001: 3). This is a further example of the layering of function from the international UN monitoring role to a national level which can more easily identify circumstances or challenges that are state-specific. Because they are based on the ground they are seen by the UN and committed governments as: 'one of the most important ways to improve domestic human rights records in emerging democracies and countries recovering from internal conflicts or times of extreme oppression' (Pohjolainen, 2006: 1).

There has been a huge increase in the number of NHRIs since the establishment of the Paris Principles (from just a few to the current approximately 110), and Pohjolainen asserts that the last decade has therefore seen the emergence of NHRIs as 'a new international human rights actor' (Pohjolainen, 2006: 1). Not only do NHRIs act domestically, they are in constant liaison with the UN, governments and other international human rights organisations, including NGOs. Because of this wide sphere of influence she said that 'newly-democratised states' are setting up NHRIs to show their willingness to comply with international human rights obligations (Pohjolainen, 2006: 2). The creation of an NHRI has therefore become a sign that a government is firmly committed to the international human rights framework, and their existence is important for robust human rights governance.

NHRIs therefore have a dual protection-implementation role and this is illustrated nicely by the work of New Zealand's NHRI, the HRC. The Commission investigates complaints of discrimination on 13 grounds and its functions and responsibilities are set out below. ${ }^{80}$ Broadly these can be described as advocacy-mediation-adjudication-

\footnotetext{
80 The 13 grounds are: sex, marital status, religious belief, ethical belief, colour, race, ethnic or national origins, disability, age, political opinion, employment status, family status and sexual orientation (see section 21 Human Rights Act 1993). Under section 5(1) of the Human Rights Act 1993 the HRC has two primary functions: '(a) to advocate and promote respect for, and an understanding and appreciation of, human rights in New Zealand society; and (b) to encourage the maintenance and development of harmonious relations between individuals and among the diverse groups in New Zealand society'. In order to carry out these functions the HRC has a number of other responsibilities under section 5(2) of the Act relating to: human rights education, programmes, activities, research, better understanding the Treaty's human rights dimensions, publishing guidelines and codes of practice, taking part in certain court or tribunal hearings, reporting to the Prime Minister about inconsistencies between domestic laws and international human rights instruments, and advising the government about the ratification of treaties.
} 
advisory-monitoring/watchdog-educational-interpreting. ${ }^{81}$ However, the Commission's role was not always that broad and has changed over time. Like the whole international human rights framework (and as has happened domestically as well), this NHRI has changed its direction and angles of focus. It was initially set up as an independent agency by the Human Rights Commission Act 1977, with a complaints mechanism focus and advisory and recommendatory powers only, but since the Human Rights Amendment Act 2001 it has become quasi-judicial and can make orders and costs. The evolution therefore over the last 30 years has been that the key human rights mechanism has moved from being a body that had an exhortation role (to Parliament and the state sector in the same way that the Ombudsman does) with a focus on non-discrimination and complaints, to having legal enforceable power and a move towards more policybased approaches.

This is an illustration of the complementarity theme of the research: the HRC has a role that is starting to combine the law+litigation and policy approaches to human rights implementation. Complementarity is therefore about the entwining of these two threads so together they make a strong rope.

\subsection{Summary}

Well before the UN was established in 1945 other international labour, peace and humanitarian bodies had acted as precursors for this emerging organisation. New

\footnotetext{
81 A little known function of the HRC is about intervening in court cases, which is mandated under section 5 of the 1977 Human Rights Commission Act. This enables them: 'To apply to a court or tribunal, under rules of court or regulations specifying the tribunal's procedure, to be appointed as intervener or as counsel assisting the court or tribunal, or to take part in proceedings before the court or tribunal in another way permitted by those rules or regulations, if, in the Commission's opinion, taking part in the proceedings in that way will facilitate the performance of its functions stated in paragraph (a) of this subsection'. What this means in essence is the Commission makes submissions on the relevant points of law without advocating for a particular party. It only intervenes where the case involves a matter of importance and they can add value to the legal argument. Chief Commissioner Ros Noonan noted at the recent NZ Diversity Forum 09 that: 'The Commission is increasingly intervening in court cases where we think we need to be promoting, explaining and providing advice on relevant human rights standards' (Noonan, 2009). The most recent case has been McAlister $v$ Air New Zealand Limited SC 49/2008 [2009] NZSC 78 brought against the airline by a senior pilot on the grounds of discrimination because of age. There were interpretive difficulties with relevant provisions in both the Human Rights Act 1993 and the Employment Relations Act 2000, and a Human Rights Commission Intervener was involved in the case to clarify this. This changing jurisdiction is important, because in the eyes of government departments the Commission would have seemed to have more 'teeth' than under its original 1977 mandate. The Commission had, however, already carried out Consistency 2000 as a result of its statutory obligation (also under section 5 of the 1977 Act). Here departments were required to self-audit and directly report back to the HRC, and this would have been the beginning of heightened departmental awareness that the implications of international human rights obligations mattered in everyday policy work. With its new 2001 powers the Commission became an even stronger spotlight on the work of individual departments, although not as suggested, in Section 5.5 of this research, strong enough in relation to the Cabinet vetting process.
} 
Zealand's involvement with these bodies, along with its advanced social and electoral policies and legislation, gave this country an edge in the world arena. Prime Minister Fraser's delegation was able to take that experience to the international table, directly influencing international public policy by helping develop the principles behind the Atlantic Charter, the UN Charter and the UDHR, and the way institutional structures such as ECOSOC were set up. The New Zealand delegation had a clear and thoughtful vision of how the UN human rights framework should be constructed. Pressure on certain issues was therefore persistent over time. During the 1940s New Zealand urged three themes: the elevation of economic, social and cultural rights and the assertion that it was the function of government to promote their realisation; the need for the legally binding nature of covenant obligations so that states would be held strongly accountable for human rights abuses; and the necessity for individuals to be able to petition the UN directly. During this nascent human rights period three developments also occurred. The principle of universality was acknowledged, which meant that human rights were recognised internationally for the first time. The Atlantic Charter had acted as a direction post towards a rights-based system. Once this system was in place the second development followed - the linking of the collective security/economic growth/human rights triangle - and the human rights component started to be taken very seriously as a key linchpin in the new world order. The third development of this period was the establishment of the Article 55 UN Charter principle of non-discrimination which now gave the international community the ability to investigate human rights abuses in member countries if this principle was being violated. While it eroded the doctrine of state sovereignty, it was a watershed concept which came to form the basis of domestic human rights legislation, policy and practice in this country.

This chapter has also shown that without the intermediary institutions of regional mechanisms and NHRIs it would be very difficult for the UN to monitor human rights from a distance. Increasing guidance from the UN helps states that might be struggling to comply with international obligations. Even for developed countries such as New Zealand, any streamlining or guidance is useful in the growth area of the domestic transfer of international human rights. How effective that transfer is, and what mechanisms are used as ratified treaty rights penetrate into the state sector, is the next part of this research as it turns from the international to the domestic arena in Chapter 4. 


\section{CHAPTER 4: STOCK-TAKE AND PLANNING}

This chapter and the next start to elaborate the detail behind complementarity. To do this, the various evaluation and planning initiatives that were carried out in the period 1994-2009 are outlined. These initiatives tried to streamline the ad hoc build-up of human rights structures, legislation and policies that had arisen over several decades. Chapter 5 that follows looks in detail at what has been done as a result of the recommendations flowing from some of these initiatives, and what can still possibly be done to further ensure that a human rights approach is deeply embedded into the public sector. As with the international framework, it is suggested that New Zealand's domestic human rights architecture has been based on a bi-fold structure: organisational and legislation. This research further suggests that there is now a tri-fold human rights framework emerging in New Zealand based on a third policy level (see Table 3), and in the next chapter it is suggested that a further fourth level for the domestic sphere (statelevel human rights governance). This chapter also illustrates two phases in New Zealand's human rights history: Phase Two (structural development, domestic lawmaking) and Phase Three (reviewing, restructuring).

\subsection{Tri-fold domestic framework: organisational, legislative, policy}

At the first level in the domestic framework - organisational - there are a number of related agencies that have human rights oversight. The main organisation is the HRC whose role has already been discussed (see Section 3.4). The Office of the Privacy Commissioner has a watchdog role on privacy issues and can investigate complaints about breaches of individual privacy, while the Ombudsman's Office investigates complaints by citizens about state agencies. The Office of the Children's Commissioner and the Office of the Health and Disability Commissioner promote and ensure the welfare of children/young people and health and disability service consumers respectively. Three government agencies are also primarily responsible for domestic and international human rights legal advice to the government: MFAT, the Ministry of Justice and the Crown Law Office. Other departments whose policies and programmes have significant human rights implications are noted in Table 3 which follows. This 
organisational level represents the Phase Two themes of structural development, while the legislative level discussed next relates to the theme of domestic law-making.

At the second level - legislation - a number of human rights-related laws have been enacted since the early 1970s (also see Table 3). The cornerstone pieces of legislation for this country's domestic human rights architecture are the Human Rights Act and NZBORA. However, as noted by the Re-evaluation of the Human Rights Protections in New Zealand report authors: 'The evolution of New Zealand's human rights legislation has occurred in a rather piecemeal fashion' (Ministry of Justice, 2000a: 27). By ratifying the core international human rights treaties this country has opened its domestic legislation, policies and practices to international monitoring. This is a long way from the 1940s when there was no developed human rights framework. New Zealand now has bilateral and multilateral human rights involvement and three permanent missions to the UN (New York, Geneva and Vienna). ${ }^{82}$

There are separate processes pre- and post-ratification: the first to become party to a treaty and the second to participate in the UN reporting system. ${ }^{83}$ The treaty-making process is overseen by the legal division of MFAT, and as noted in Chapter 2.1 there is no automatic uptake of UN instruments into New Zealand's domestic legislation. A treaty incorporation takes place in similar manner to Australia and Sweden instead of the self-executing approach of, for instance, the USA and Korea. Cabinet approval is needed once a treaty text is ready and all multilateral and major bilateral treaties must be presented - along with a National Interest Analysis - to the House of Representatives. The treaty is then considered by the Foreign Affairs, Defence and

\footnotetext{
82 There is a full-time New Zealand delegate to the Third Committee of the UN General Assembly in New York which focuses on human rights issues and the Geneva representative also monitors this area. More recently New Zealand has developed a relationship with the new Human Rights Council. The UN Human Rights and Commonwealth Division of MFAT oversees the international human rights relationship with the UN.

83 MFAT has given a list of general reasons for non-ratification, noting that many of them are relevant to Pacific Island states, which 'may explain the relatively low level of human rights treaty ratifications' in these countries: 'lack of political will to accord ratification priority relative to other priorities; inconsistencies between the treaty and domestic law and practice; opposition to certain provisions of a treaty by strong domestic interest groups (e.g. on the death penalty, women's rights to own land etc); the length of time required to work through the domestic political and legal implications of ratification to ensure compliance; concern at the resource implications of the requirement to report periodically to the respective UN treaty monitoring bodies; greater weighting given by some governments to the interests of the state, economic development and security over the pursuit of civil and political rights as exercised in Western countries; cultural influences: the view that some international treaties are not appropriate to a country's particular situation and needs; lack of democracy and/or rule by an authoritarian government; lack of a working government; sensitivity to international scrutiny and a desire to minimise such scrutiny; resource constraints; poverty and lack of literacy limiting wider understanding of, and support for, human rights; a general lack of awareness among policy- and decisionmakers' (NZ House of Representatives, 2005: 50). However, Pacific states can vary significantly between each other, even within states themselves, about issues such as land inheritance and entitlement.
} 
Trade Select Committee. The Government defers taking binding treaty action until the provisions of the treaty are implemented in domestic law. Formal treaty action is known as ratification or accession and commits New Zealand to obligations relating to that instrument. The final step, once acceded or ratified, is that the treaty is deposited in a treaty depository and listed on a treaty register maintained by the legal division of MFAT. ${ }^{84}$ If countries do not feel ready to bring domestic legislation into alignment with international human rights treaty obligations, and this is holding up ratification, they can register a reservation. New Zealand currently has reservations registered for the ICESCR, CAT and UNCROC and ICCPR (UNGA, 2009c: 3$){ }^{85}$

\subsection{Evaluation initiatives}

The need to assess the fragmented growth of New Zealand's human rights framework has resulted in much reflection since the mid-1990s. Table 4 shows a timeline of the major initiatives and this section will look at what they were about, how they relate to each other, and the key issues arising from this intensive attempt to streamline this area. This will then lead into an examination of some of the main suggestions arising from these initiatives. This section of the chapter illustrates the reviewing and restructuring key themes of Phase Three of New Zealand's human rights history.

84 For more information on the treaty-making process in New Zealand see www.mfat.govt.nz/Treaties-and-International-Law/03Treaty-making-process/index.php.

85 Specifically this means that for: the ICESCR, New Zealand legislation about trade unions and industrial relations may not be fully compatible with Article 8; for CAT, the Government reserves the right to compensate torture victims (as per article 14) at the Attorney-General's discretion; for UNCROC, (a) because the Government considers that the rights of the child are adequately covered in current legislation, any further measures suggested in article 32(2) will not be carried out, and (b) the Government reserves the right to mix juveniles and adults if unavoidable, or if may be of benefit to the juvenile (see article 37(c); for the ICCPR, (a) article 14(6) has a reservation in relation to ex gratia payments for miscarriage of justice; (b) article 20 has a reservation about not introducing further hate speech legislation; and (c) the trade union and juvenile reservations also apply in relation to this covenant. 
Table 3. Four-fold domestic human rights framework

1 ORGANISATIONAL LEVEL

INSTITUTIONS

Human Rights Commission

Office of the Privacy Commissioner

Ombudsmen's Office

Office of the Children's Commissioner

Office of the Health and Disability Commissioner

MINISTRIES AND AGENCIES

Department of Prime Minister and Cabinet

Ministry of Foreign Affairs and Trade

Ministry of Justice

Crown Law Office

NZ Defence Force

Ministry of Social Development

Ministry of Health

Ministry of Education

Ministry of Women's Affairs

Ministry of Youth Affairs

Ministry of Pacific Island Affairs

Te Puni Kokiri

NZ Police

Immigration Service in Department of Labour

Department of Corrections

2 LEGISLATION/COURTS LAW+LITIGATION LEVEL

HUMAN RIGHTS RELATED-LEGISLATION

Cabinet vetting process:

New Zealand Bill of Rights Act (1990)

Human Rights Act (1993)

Privacy Act (1993)

Other related legislation:

Equal Pay Act (1972)

Ombudsman Act (1975)

Disabled Persons Community Welfare Act (1975)

Human Rights Commission Act (1977)

Official Information Act (1982)

Constitution Act (1986)

Parental Leave and Employment Protection Act (1987)

Abolition of the Death Penalty Act (1989)

Crimes of Torture Act (1989)

Children, Young Persons and their Families Act (1989)

Health and Disability Commissioner Act (1994)

Domestic Violence Act (1995)

Human Rights Amendment Act (2001)

JUDICIAL AND QUASI-JUDICIAL ENFORCEMENT AGENCIES (e.g. HRC)

3 POLICY LEVEL

Inter-departmental liaison and training

Non-judicial policies and practices

Early mainstreaming

4 STATE-LEVEL HUMAN RIGHTS GOVERNANCE

Human rights governance level 
Table 4. Major evaluation and planning initiatives/documents 1994-2009

\begin{tabular}{|l|l|l|}
\hline DEVELOPMENT & ORGANISATION & YEAR \\
\hline Evaluation & HRC & $1994-1998$ \\
\hline Consistency 2000 & $\begin{array}{l}\text { Independent ministerial report, } \\
\text { published by Ministry of } \\
\text { Justice }\end{array}$ & 2000 \\
\hline $\begin{array}{l}\text { Re-evaluation of the Human } \\
\text { Zealand }\end{array}$ & Ministry of Justice & 2001 \\
\hline Compliance 2001 & HRC & 2004 \\
\hline $\begin{array}{l}\text { Human Rights in New Zealand } \\
\text { Today }\end{array}$ & $\begin{array}{l}\text { Foreign Affairs, Defence and } \\
\text { Trade Committee }\end{array}$ & 2005 \\
\hline $\begin{array}{l}\text { Inquiry Into the Role of Human } \\
\text { Rights in Foreign Policy }\end{array}$ & HRC & 2005 \\
\hline Planning & HRC & 2008 \\
\hline $\begin{array}{l}\text { New Zealand Action Plan for } \\
\text { Human Rights 2005-2010 }\end{array}$ & MFAT & 2009 \\
\hline The Human Rights Approach \\
\hline $\begin{array}{l}\text { New Zealand's Universal } \\
\text { Periodic Review }\end{array}$
\end{tabular}

\subsubsection{Consistency 2000}

The first initiative occurred very quickly after the Human Rights Act was passed in 1993 and was a statutory obligation on the HRC set out in that Act. The project started in 1994 and a final report entitled Consistency 2000 was published by the Commission in December 1998 (HRC, 1998). Broadly Consistency 2000 was an examination by the HRC of all laws, policies and practices to check consistency with the antidiscrimination provisions of the Human Rights Act. The new Act had extended the number of grounds of unlawful discrimination from four to 13 . However, there was a period of exemption for the public sector until 1 January 2000 (HRC, 1998: 6-7). Section $5(1)(\mathrm{i}-\mathrm{k})$ of the Act had given the HRC the statutory authority to carry out the Consistency 2000 project which had four phases, including a self-audit by government 
agencies. ${ }^{86}$ The Commission believed this self-audit 'provided an unprecedented human rights educational opportunity in the public sector' (HRC, 1998: 17). The Consistency 2000 report to the Minister of Justice was eventually produced in December 1998, despite the project suffering from lack of government support when in June 1997 the National Cabinet made a decision to abandon the project. The HRC continued on, albeit without funding, and noted in the final report that:

The project was rather like a half-completed building - the plans had been drawn, the materials purchased, the builders contracted, the foundations dug and the superstructure erected. With the passing of time and a little more effort the walls, the roof and the interior would have been completed (HRC, 1998: 8).

The report also noted that at the time the project was scaled down much groundwork had been completed and the results were starting to happen. ${ }^{87}$ The HRC had found that a number of common themes and issues had emerged, and took note of any generic issues as these could flag possible areas of 'systemic discrimination' (HRC, 1998: 12).

The reason given by Cabinet for abandoning funding of the Consistency 2000 exercise in June 1997 was that they wanted to try 'a different approach to government compliance with the Human Rights Act' (HRC, 1998: 8). This meant it only felt liable to comply with the Act in areas where it acted 'in essentially the same manner as the public sector, such as employment and access to public buildings' and except for these cases 'it would remain exempt permanently in respect of legislation and other policies and practices' (HRC, 1998: 24). In a briefing note of 10 August 1998 the Rt Hon Doug Graham (Minister of Justice) stated that:

\footnotetext{
86 Sections 5(1) (i-k) of the Act read: '(i) To examine, before the 31st day of December 1998, the Acts and regulations that are in force in New Zealand, and any policy or administrative practice of the Government of New Zealand: (j) To determine, before the 31st day of December 1998, whether any of the Acts, regulations, policies, and practices examined under paragraph (i) of this subsection conflict with the provisions of Part II of this Act or infringe the spirit or intention of this Act; ( $\mathrm{k}$ ) To report to the Minister, before the close of the 31st day of December 1998, the results of the examination carried out under paragraph (i) of this subsection and the details of any determination made under paragraph (j) of this subsection'. The four phases were: (1) a self-audit by government agencies; (2) an external audit by the HRC; (3) an update report by government agencies; and (4) determinations made by Commissioners leading to a report to the Minister of Justice by 31 December 1998. After the initial planning had been carried out in 1994 officials were invited to self-audit their department's Acts, regulations and practices. The Commission was then to externally audit the self-audited data for any conflicts with Part II of the Human Rights Act or infringements of its spirit or intention. These infringements were reported as Part B: Instance Reports of the final report. If a conflict or infringement of rights was identified it was put on an electronic self-audit database programme developed by the HRC. The Ministry of Labour had agreed to act as a pilot agency in 1995, but the Department of Social Welfare also became 'almost another pilot department' because of the sheer number of social security laws, policies and practices that had to be assessed against the anti-discrimination provisions (HRC, 1998: 21).

87 Work that had been carried out by the time of the Cabinet decision included: 'Consultation had been undertaken, a methodology had been developed and tested, technology was in place, training of officials was almost completed, interpretation of key legal points had been clarified, self-audits were about half-complete and Commissioners had commenced making "recommended" or provisional determinations' (Ibid 1998: 8).
} 
The reason for repealing the Consistency 2000 project is that there is little more to be gained by continuing the very detailed audit process, having regard to the substantial resource commitment involved. Preliminary indications were that many inconsistencies found were repetitive or minor in nature. The Government decided that a better approach would be for Chief Executives of each government department to be responsible for assessing and managing their departments' legal risks in complying with the Human Rights Act. Legislation and regulations that conflict with the Human Rights Act will be addressed as they come up for review (Graham 1998: 2).

Because the HRC had until then been working towards the 31 December 1998 goal set out as a statutory obligation, they were extremely concerned about the Cabinet decision. As a result the Commission noted in its final report:

It was decided to concentrate on trying to persuade the government that the new direction it was taking was misconceived, retrograde, and highly unsatisfactory in human rights terms; and that it would lead to severe criticism both domestically and internationally. In its 1997 Annual Report the Commission stated that "the implications of a broad, permanent exemption are serious. It would represent a significant step backwards in the observance of human rights in New Zealand" (HRC, 1998: 24).

During the latter half of 1997 and until the Human Rights Amendment Bill was introduced into the House of Representatives in August 1998 discussions occurred between the HRC and the government 'to obtain the best result possible in human rights terms' (HRC, 1998: 25). Three outcomes in this period leading up the introduction of the Bill were: meetings between the HRC and ministers and officials finally negotiated a situation where the exemptions were 'generally narrower' than previously indicated by the government; it was decided legislation and regulations would be checked for inconsistencies with the Human Rights Act when they came up for review; and Chief Executives became responsible for 'identifying and resolving compliance issues' for government policies and practices (HRC, 1998: 25). After a shaky period of trying to resolve these issues the HRC was able to assert in its 31 December 1998 final report:

Compared with the proposals 18 months ago the model for governmental compliance with human rights in New Zealand, encapsulated in the Human Rights Amendment Bill and new official processes and responsibilities, is considerably improved (HRC, 1998: 25).

The Human Rights Amendment Bill 1998 (No 1) was not enacted due to a lack of support in the House, but instead the Human Rights Amendment Bill 1999 was passed. The HRC met its statutory obligations by submitting the determinations on the audit material gathered by the original deadline of 31 December 1998. In 2000 the Hon Margaret Wilson, Associate Minister of Justice and Attorney General, commissioned the independent ministerial report on human rights protections in New Zealand. The re- 
evaluation team made six recommendations about the Consistency 2000 project. $^{88}$ In examining the project they concluded the following, and it is quoted at some length as it gave a comprehensive assessment of the project:

... the Government of the day decided to review the Consistency 2000 project in light of the significant resources committed to the project, and preliminary indications that many of the main areas of inconsistency were minor or repetitive in nature. ... there have been a number of real difficulties with the project in practice. In hindsight it was overly ambitious. The audit reported large volumes of material without any systematic method of prioritising the pressing issues, and on matters in the abstract, which were only potentially discriminatory.

... the Human Rights Act only covers a number of limited areas - rather than the whole of government activity. Those statutes that conflict with the core areas of the Act are actually rare. The audit, however, took a very broad view of this (invoking the 'spirit and intention' of the Act as required by s 5) ... the proper standard by which to assess these broader forms of government activity is that set out in the New Zealand Bill of Rights Act 1990 and not the Human Rights Act. That is not to say that some of the information collected in the exercise is not valuable and that on occasion those standards will not overlap. Nevertheless a great deal of confusion has resulted.

... The original purpose of the Consistency 2000 audit, or database, was to identify possible areas for second phase consideration. Enough has now been done by way of identifying problematic areas. Even though it was not as thoroughgoing as originally conceived, a legislative audit is never likely to be an exhaustive or definitive way of identifying areas of inequality. Significantly, the most pressing issue of equality recognised by the present government was not signalled by the Consistency 2000 project at all. Undoubtedly the disparity in economic health and educational status between Māori and the rest of the population is a major issue facing New Zealand today. Neither did the audit particularly raise as a concern the issue of indirect discrimination against women. A legislative project such as this is no substitute for empirical research, monitoring effects of legislative changes, and good policy analysis (Ministry of Justice, 2000a: 40, 41, 45).

This was an interesting phase in the history of New Zealand's human rights history. A cornerstone piece of legislation - the Human Rights Act 1993 - had been enacted, including the statutory provision in it for the HRC to review inconsistencies in all other Acts, policies and practices across the government sector. This was swiftly commenced in 1994, but by mid-1997 (18 months out from the deadline which the HRC was steadily working towards) a government decision caused funding to cease. The Commission did deliver on the incomplete project by providing a final report for the 31

\footnotetext{
88 These recommendations were: '(1) The Justice and Law Reform Committee should have a continuing role - and progress on specific themes should be reported to it on a periodic basis; (2) Subject to resolution of the relevant resource issues, officers from the Ministry of Justice Bill of Rights monitoring team should be allocated to help departments find solutions. Outside help might also be sought; (3) A pool of information should be made available to departments struggling with similar problems, which includes worked examples showing how the statutes could be made compliant; (4) Processes should be created by which committed lead agencies can mentor other agencies not yet up to speed; (5) Attorney General's opinions on Bill of Rights compliance should be made available to departments, and publicly, in order to build a jurisprudence and rights culture; (6) Chief Executives should be required to include in the department's annual report progress on human rights and Bill of Rights compliance' (Ministry of Justice, 2000a: 53).
} 
December 1998 deadline. However, a re-evaluation team writing the independent ministerial report in 2001 analysing the Consistency 2000 project had misgivings about the size of the task and even the way it was scoped, but found much value in the work that was done. This is a clear example of the development of New Zealand's human rights framework: the ad hoc build-up was acknowledged and an attempt was made to streamline the fragmentation. Even though this attempt (Consistency 2000) may have had its own difficulties, it was a major project in ironing out inconsistencies with the Human Rights Act. It was also, as noted earlier, a chance for departments to self-audit and was a unique human rights educational opportunity for the public sector.

It should also be noted that while the re-evaluation team were mainly concerned about hard law inconsistencies, the HRC approach through its statutory obligations under section 5 of the Act started to look at the also important (and harder to detect) discriminations against the 'spirit and intention' of the Act. This highlights the difference between a primarily law-based vs multi-disciplinary approach to human rights. This approach was confirmed in the HRC's 2004 Human Rights in New Zealand Today report which stated that it went beyond recording 'the extent to which New Zealand's laws conform' and also attempted 'to assess the extent of substantive compliance: to what extent people's experiences reflect an active respect for human rights, to what extent people are protected from human rights abuses and violations' (HRC, 2004a: 24). That is, it went beyond the law+litigation model. At the very least the Consistency 2000 project began the 'conversation' the state sector had with itself about ensuring inconsistencies were ironed out at every stage in the process and started to mainstream the issue of compliance into everyday policy work.

\subsubsection{Re-evaluation of the Human Rights Protections in New Zealand (2000)}

This independent ministerial report has already been mentioned and a range of individuals and organisations were consulted by the re-evaluation team during the writing stage. ${ }^{89}$ The report noted that:

89 These included: 'a cross-section of NGOs, parliamentarians, academic and government departments, as well as the Commissioners and staff of New Zealand's human rights organisations', and 1,365 organisations and individuals made public submissions (Ministry of Justice, 2000a: 18; 2001: 6). 
New Zealand's laws and institutions dealing with human rights have grown organically, largely in response to the adoption of international standards we have helped to develop ... there is strong support for the view that this is a timely point at which to take stock of our laws and institutions relating to human rights (Ministry of Justice, 2000a: 6, 7).

The re-evaluation team had been given six terms of reference. ${ }^{90}$ The fifth one about making sure international obligations are factored early in the policy-making process is most relevant to this research. The team made recommendations in four key areas, first about clarifying the status of New Zealand's human rights law. They examined the 'role, function and inter-relationship' between the Human Rights Act and NZBORA and found that 'New Zealand's human rights obligations and the relationship between these two Acts are not well understood by the public, politicians and many government departments' (Ministry of Justice, 2001: 7). The team determined that the difference between the two Acts was that NZBORA's aim was: 'to regulate and limit the power of government and public actors' i.e. it stated 'the general anti-discrimination principle to which government acting as government should adhere' (largely a public sector focus). ${ }^{91}$ On the other hand the Human Rights Act was viewed as 'a detailed working out of the government's duty to protect its citizens from discrimination perpetrated by fellow citizens' (largely a private sector focus) (Ministry of Justice, 2000a: 27-28, 30). Secondly the team reviewed this country's domestic human rights institutions. They found problems with existing human rights agencies which tended to:

... be complaints-driven; be small and fragmented resulting in efficiency problems; neglect their educational and advocacy roles because of this; current commissioner model means that commissioners become very involved in day-to-day work - losing sight of the education work and long-term goals (Ministry of Justice, 2001: 7).

90 The terms of reference were: '(1) To re-evaluate the nature and scope of the provisions of the Human Rights Act 1993, and if necessary, recommend amendments that would contribute to the further mainstreaming of human rights considerations in New Zealand. (2) To develop recommendations for the relationship of our domestic human rights laws to other legislation in a way that best promotes and protects the human rights of New Zealanders in accordance with international conventions. This should include consideration of the primacy or otherwise of human rights law to other legislation. (3) To re-evaluate the roles, inter-relationships, operation and structures of the Human Rights Commission, Race Relations Conciliator, the Privacy Commissioner and Complaints Review Tribunal, and if necessary, recommend changes that would enhance the effective promotion and enforcement of New Zealand's domestic human rights laws. This should include the re-evaluation of options for the resolution of human rights complaints. (4) To re-evaluate the inter-relationships of the above agencies with the Commissioner for Children and Health \& Disability Commissioner, given their respective statutory roles. (5). To re-evaluate the adequacy of current mechanisms, and if necessary, recommend changes that would ensure that international human rights obligations are taken into account in the development and implementation of government policy, practice and New Zealand legislation. (6) To consider whether New Zealand would benefit from a National Plan of Action for the promotion and protection of human rights as recommended by the UN World Conference on Human Rights [held in Vienna in 1993], and if necessary, to recommend a process for the development of a New Zealand National Plan of Action' (Ministry of Justice, 2000a: 16-17).

91 This raises the issue of how government attempts to improve the human rights framework are important because they head off possible concerns that New Zealand could be exposed overseas for domestic rights derelictions, especially when local lobby groups become involved in the exposure. Not only is there the politics of exposure, but the politics of pressure, where there is such intense lobbying on issues (such as New Zealand's stance not to support the UN Indigenous Rights Declaration) that decisions are reversed. See Section 6.3 for more information on the Declaration. 
The team recommended a new NHRI which included that it be: 'strategically focused; have an increased education and advocacy mandate; maintain some complaints work; promote discussion of the Treaty of Waitangi and domestic and international human rights law' (Ministry of Justice, 2001: 7-8). This new NHRI would consolidate the HRC and the Race Relations Office together (the Human Rights Amendment Act 2001 did amalgamate these two agencies). They also suggested that a Complaints Review Tribunal with more powers should deal with complaints and the Amendment Act eventually created the Human Rights Review Tribunal (HRRT). The team then looked at policy-making improvements. It was concluded that 'the public sector understanding of human rights issues needs to be improved' (Ministry of Justice, 2001: 8), and 12 recommendations were made. ${ }^{92}$ Finally a national plan of action was discussed. The report recommended that the new NHRI should be responsible for leading the development of this plan, and four years later the HRC did produce the New Zealand action plan for human rights for the period 2005-2010. ${ }^{93}$ It was hoped that a plan would help in 'planning the large systemic changes recommended in the re-evaluation report' (Ministry of Justice, 2001: 8).

A Cabinet paper and a Cabinet Minute both endorsed the recommendations of the reevaluation report (Cabinet Office, 2001a, 2001b). The first, a paper on human rightsrelated issues, proposed the establishment of an inter-departmental working group to:

... achieve the goals of: fully integrating a human rights perspective into policymaking; ... rationalising departmental responsibilities including in relation to international treaty obligations (Cabinet, 2001a: 1-2).

The Cabinet Minute was very specific in its directions:

\section{Mainstreaming Human Rights Considerations in the Policy and Legislative Process}

21 directed that an inter-departmental working group

21.1 be established to assess the Re-evaluation report's recommendations for improving the mainstreaming of human rights considerations in legislation and policymaking and to develop a workplan, including priorities, a timeline and required resources, to be reported back by 30 August 2001 to the Prime Minister, Associate Minister of Justice (Hon Margaret Wilson), Minister of State Services, Minister of Foreign Affairs and Trade, Minister of Māori Affairs and Minister for Disability Issues; 


\title{
21.2 be chaired by the Ministry of Justice;
}

21.3 include representatives from the State Services Commission, Department of Prime Minister and Cabinet, and Ministry of Foreign Affairs and Trade; and

21.4 invite the Human Rights Commission, the Office of the Race Relations Conciliator and the key social policy and population agencies (Ministry of Social Policy, Ministry of Health, Ministry of Education, Department of Labour and Te Puni Kokiri) to have a representative on the group (Cabinet, 2001b: 4).

What eventually happened in relation to this Cabinet direction, including the high-level participation of Ministers and inter-agency staff in this process? Four years later MFAT noted in its 2005 submission to the Foreign Affairs, Defence and Trade Committee about human rights and foreign policy that it was aware that:

\begin{abstract}
Cabinet has directed that the Ministry of Justice lead an interdepartmental group to assess the recommendations of the Re-evaluation report and to develop a work plan designed to improve the Mainstreaming of human rights considerations in legislation and policymaking [CAB Min (01) 17/6D, paragraph 21 refers]. The preliminary work on this project has recently begun (NZ House of Representatives, 2005: 59).
\end{abstract}

An inter-agency working group that the Cabinet paper and Cabinet Minute had endorsed was set up in 2002, but eventually focused on helping the HRC develop a national plan of action instead of early mainstreaming. The group has since faded in a formal sense, so there is now no official inter-departmental training for policy advisors and each department deals with this issue on a case-by-case basis. It is not surprising, however, that this work became diverted. The re-evaluation report raised many issues, including the need for a national action plan, and this involved a major effort between 2002 and 2005 with the HRC working alongside relevant departments. The HRC had already been through the large Consistency 2000 project and the Ministry of Justice the Compliance 2001 audit. The action plan was published in 2005, and a year earlier the HRC had also published the large status report Human Rights in New Zealand Today (HRC 2004a). A lot was achieved in a very short space of time, and because of limited resourcing issues it is no wonder that the 12 recommendations of the re-evaluation team were not carried out precisely as instructed by the Cabinet Minute. However, as suggested in the next chapter some useful strategies became 'lost' in the system and they could well need revisiting.

The re-evaluation team's brief and recommendations were wide-ranging and reviewed all aspects of the human rights framework in New Zealand. It is also a useful document showing the fragmentation that has occurred in this framework, but also a pointer to the re-integration that has been happening and is still required. As well as this, the reevaluation report was a clear example of the reviewing and restructuring key themes of 
Phase Two. It was a much more wide-ranging initiative than the Consistency 2000 project which had a brief to focus on the law+litigation aspect of inconsistent legislation. The re-evaluation report, however, started to examine the specific processes and mechanisms of New Zealand's human rights framework as well as the law+litigation aspects. It also fed into the development of the Human Rights Amendment Act 2001.

\subsubsection{Compliance 2001 (and the Human Rights Amendment Act 2001)}

A similar initiative occurred a year after Consistency 2000. The government had become so concerned about this topic that 'compliance' features in the name of this second project. The international legal protection in having policy advisors literate in human rights obligations was starting to be taken very seriously, but it was also important to have compliant legislation for them to work from. The history of the initiative is that in December 2000 Cabinet agreed to a new auditing process for improving the compliance of legislation and government policies and practices with the Human Rights Act. The process, known as Compliance 2001, was managed by the Ministry of Justice but was not a revival of the previous Consistency 2000 initiative. Instead the new project relied on government departments to complete their own audits of legislation, policies and practices and self-determine whether any issues of inconsistency needed to be resolved. ${ }^{94}$ Following the two audits - Consistency 2000 and Compliance 2001 - the Human Rights Amendment Act 2001 was enacted. Two legislative-related features of this Act, as detailed in New Zealand's fifth periodic ICCPR report in 2007, were:

- Government activity (except in relation to employment, sexual or racial harassment and victimisation, which are subject to the general provisions of Part 1 of the Act) is now the subject to the single discrimination standard under s 19(1) of the Bill of Rights Act

- The broad exemption from the Human Rights Act for certain government activities is removed (MFAT, 2007: 19).

\footnotetext{
94 The process was divided into four streams: 1) legislation, practices and policies concerning social delivery; 2) other significant legislative inconsistencies; 3) minor inconsistencies; and 4) general inconsistencies in policies and practices. The Ministry of Justice organised a series of seminars to assist officials undertaking the audit. A Human Rights Reference Group was also formed with members from the Ministry of Justice, the HRC, the Crown Law Office and the Department of Prime Minister and Cabinet. Under the Compliance 2001 process all government departments were required to report to their Ministers and the Ministry of Justice by 2 March 2001.
} 
However, the Act also heralded institutional reform (consistent with the Phase Two restructuring key theme), including the disestablishment of the Race Relations Office and the creation of a Race Relations Commissioner position. A new Office of Human Rights Proceedings was set up to handle discrimination cases using public funding. Chief Commissioner Rosslyn Noonan commented on the changes resulting from the Human Rights Amendment Act 2001:

\begin{abstract}
If the only knowledge you had of the Human Rights Amendment Act 2001 had come from listening to Parliamentary debates during the second reading and the Committee stages of the Bill, then you could well have believed that the new Human Rights Commission was going to be a frightening manifestation of Big Brother (or in this case Big Sister, which was apparently infinitely worse), thought police, social engineering and political correctness ... However, despite the popular endorsement of the need for a Human Rights Commission aspects of the Parliamentary debate did reflect a partial public, and certainly media emphasized, perception that human rights are either: simply a device to enable the disgruntled and inadequate to blame someone else for personal failure; or a mechanism to allow sharp lawyers to win cases for otherwise undeserving clients; or that they are frequently used on trivial issues and to impose conformity. The first of a number of challenges facing the new Human Rights Commission was therefore to strengthen and extend knowledge and understanding about human rights and responsibilities - to take human rights out of the lawyers' offices and into the community; to encourage that human rights are about more than anti-discrimination laws, important though those are, and that they have real value for every person ... (Noonan, 2008: 4-5).
\end{abstract}

Another important feature of the Act was that the newly created HRRT could now make Declarations of Inconsistency (already discussed in Section 1.2.1) if discriminatory legislation was identified. In terms of this last point, both the Consistency 2000 and Compliance 2001 initiatives focused on clarifying inconsistencies between the Human Rights Act and other legislation. As already noted, since the Amendment Act came into force, if an enactment is found to be inconsistent with the Human Rights Act, the HRRT can issue a Declaration of Inconsistency. Just eight years after the Human Rights Act was passed, this fine-tuning of the human rights framework (both institutionally and structurally) with the Amendment Act clarified the roles of the various agencies and the government's anti-discrimination liability, and gave some real teeth to an inconsistency watchdog mechanism. The next initiative, however, took a stock-take not so much of the structures/institutions and mechanisms, but of how well they were actually being implemented to various (often vulnerable) groups in New Zealand.

\title{
4.2.4 Human Rights in New Zealand Today (2004)
}

This 2004 report was the 'first comprehensive assessment of the status of human rights in New Zealand' (HRC, 2004a: 19) and was used as the basis of the action plan for 
human rights for 2005-2010 (discussed more fully in Section 4.3.1). Like the reevaluation report which had already been carried out in 2001 this report was also a stock-take of 'how well the rights so passionately acclaimed in 1948 are recognised and respected here in 2004' (HRC, 2004a: 19). The report also flagged the HRC's intention of developing human rights indicators:

In the absence of agreed international or national indicators or measures of human rights outcomes, this report is the first New Zealand attempt to provide a basis for the development of indicators that are appropriate for our national context (HRC, 2004a: 25).

It is divided into six sections with the middle four focusing on: the rights of children and disabled people; civil and political rights; economic, social and cultural rights; and race relations. The report asked: 'Where do we do well in New Zealand in terms of human rights? Where do we need to do better?'(HRC, 2004a: 24). It also noted that the UN has identified key features of national human rights protection systems: democracy; the rule of law; an independent and corruption-free judiciary that applies international human rights; good governance; specialised human rights institutions and formal procedures for accountability; human rights information and education; an active civil society; and a focus on the most vulnerable parts of the population (HRC, 2004a: 22). This is therefore a good example of an NHRI acting in its intermediary capacity between the UN and a state, trying to educate domestically about UN guidelines. In the report conclusion it was stated that New Zealand has most of the elements essential for the implementation of these features above, although pressing issues were still outstanding. ${ }^{95}$

Finally the report looked at the challenge of developing a national plan of action. This included the early mainstreaming of these rights into central and local government policy making, and developing reliable human rights measures and indicators. This report represents the last of the stock-take initiatives for the HRC, and this thesis now turns to a health check of a different kind: the status of human rights in foreign policy. 


\subsubsection{Inquiry into the Role of International Human Rights in Foreign Policy (2005)}

In 2005 the Foreign Affairs, Defence and Trade Committee published an inquiry report into the role of international human rights in foreign policy. This section, which straddles the international-domestic human rights framework, is included in the evaluation initiatives because it throws a wider than usual net about the impact of international human rights in the state sector. In particular, this issue touches on the key point for this thesis of human rights training. In the report the committee noted the complexity of the topic of human rights in foreign policy and the 'tendency of international human rights issues to arise in highly-politicised circumstances' (NZ House of Representatives, 2005: 5). It also noted that human rights issues appear in New Zealand through a number of sources, and it is from this varied material that advice is given to ministers and international meeting delegates about policy objectives and strategies. ${ }^{96}$

The committee also commented that 'human rights considerations are central to New Zealand's foreign policy beyond compliance with international obligations' because the values contained in them already underpin society and are essential to world peace and security (NZ House of Representatives, 2005: 5). The committee endorsed domestic measures in the area such as the then just published action plan for human rights for 2005-2010. They were pleased to note that it contained a long-term strategy for fulfilling international human rights obligations (NZ House of Representatives, 2005: 6). It is good to see one set of report authors taking note of the existence of another report at the time, but this was not always the case between the various initiatives set out in Table 4. Because of the increasing role of human rights in foreign policy the committee felt it necessary to have a government strategy that would be realistic at New Zealand's three levels of engagement: multilateral, regional and bilateral. ${ }^{97}$

\footnotetext{
96 These include domestic diplomatic reporting, the UN, HRC work, NGOs such as Human Rights Watch and Amnesty International, human rights reports from other governments such as the USA, and the media (NZ House of Representatives, 2005: 62).

97 MFAT states that 'New Zealand is a committed multilateralist in relation to human rights as in other areas of foreign policy activity' and that this country contributes to: 'Multilateral human rights diplomacy, including the improved implementation of existing instruments; Engaging in new standard-setting exercises; Negotiating resolutions on both thematic and country human rights issues at the main international human rights meetings; Participating in regional human rights fora' (MFAT, 2005: 34).
} 
From the committee's report the main areas of international human rights engagement New Zealand has across the various levels and relationships have been identified:

- $U N$ - New Zealand is an observer state on the Commission on Human Rights and a full member of the Third Committee of the UN General Assembly. Two of the posts (Geneva and New York) are especially focused on human rights issues.

- Commonwealth - New Zealand signed the 1991 Harare Declaration that endorses human rights and democracy as basic principles of the Commonwealth. Human rights abuses among member nations are taken seriously and the Commonwealth Ministerial Action Group investigates these in countries such as Sierra Leone, Nigeria, Zimbabwe and Gambia.

- Regional level - New Zealand is a participant in the Asia Pacific Forum (APF) of NHRIs. The New Zealand HRC and the Australian Human Rights and Equal Opportunities Commission (HREOC) were jointly 'prime movers' behind the establishment of the APF.

- Bilateral level - strategies have been developed to raise the issue of human rights concerns in other states (e.g. the Sudan, Iran, Myanmar and Iraq), including diplomatic and ministerial dialogue, on a sensitive case-by-case basis; and practical constructive help is given to developing countries wherever appropriate.

- Multilateral trade relationships - trade is seen to be related to human rights protection. MFAT noted that: 'The WTO system is part of the international architecture created after World War II to promote peace, security, prosperity and human rights'. World economic prosperity is also seen to underpin political freedom. One area New Zealand has strongly supported is the promotion of core labour standards that protect workers in developing countries.

- Military relationships - New Zealand does review its military assistance when there are clear abuses of human rights by regimes. It also screens the export of military equipment to avoid those countries where the weapons could be used to carry out human rights atrocities (NZ House of Representatives, 2005: 22-27, 3, $48,58,63)$. 
New Zealand is therefore able to raise awareness of human rights at a number of levels e.g. Commonwealth, the APF, bilateral, trade and military.

\subsection{Planning for the future}

By the mid-2000s the stock-take was largely completed, the implications of the Human Rights Amendment Act 2001 had been worked through, and the focus had now turned to planning a way forward. An important part of this was identifying problematic areas that needed realistic strategies to ensure progress was in fact made over time and this fits with the Phase Three theme of long-term strategising.

\subsubsection{New Zealand Action Plan for Human Rights (2005-2010)}

Human Rights in New Zealand Today had taken a hard look at how effectively human rights were being implemented to various groups and this research became the basis for the topics in the action plan that was produced by the HRC. Looking at the broad concept of a national plan of action (NPA), MFAT stated:

\footnotetext{
Essentially, an NPA represents a strategic plan for the long-term fulfilment of international rights obligations and implementation of domestic human rights policies or standards. NPAs can be important means of locking-in high-level political commitment to human rights in states. They are also a natural step towards national capacity building as they expose gaps in domestic law and practice (NZ House of Representatives, 2005: 61).
}

The action plan sets out what is required to achieve measurable improvements between 2005 and 2010 and it concluded that: 'New Zealand meets international human rights standards in many respects, and often surpasses them' (HRC, 2005a: 2). It was produced after extensive government, NGO and public consultation and identified 'key human rights outcomes and the actions needed to achieve them' (HRC, 2005a: 3). The plan took into account the pressing issues that had been identified in Human Rights in New Zealand Today. It looked broadly at issues for children, disabled people and race relations and then examined first and second generation rights and the policy and legal framework for the protection and promotion of human rights. Given the pressing issues mentioned a strong human rights framework was suggested which would involve: the place of the Treaty of Waitangi, the rule of law, good governance - applying human rights in the development of legislation and policy (hence complementarity), human rights education, and accountability - monitoring human rights (HRC, 2005a: 37-40). 
The HRC has continued to work on this stronger human rights framework, and a concrete part of this is The Human Rights Approach discussed below.

\subsubsection{The Human Rights Approach (2008)}

The HRC distributes material and information about the Human Rights Approach to policy-making agencies. This approach is based on a methodology first set out in the UN Economic and Social Council's (2003b: 8) report on the promotion and protection of human rights and is designed for use in several areas: "policy development and advice, advocacy and lobbying, baseline surveys, monitoring and evaluation, public hearings, social audits, inquiries, litigation and education' (HRC, 2008a: 1). The HRC regards the Human Rights Approach as being best international practice and it involves six tools or elements. ${ }^{98}$ These six elements had been applied to the underlying analysis contained in Human Rights in New Zealand Today. The HRC believed that adopting the Human Rights Approach will have many benefits, which reflect the concerns of this research:

It will help to sustain democracy if this approach is taken to developing and delivering legislation, policy and practice; it will make human rights-protecting legislation more accessible and enable the incorporation of second as well as first generation rights; and it will help all rights-holders to assess how their rights can be put at the heart of the design and delivery of public services (HRC, 2008a: 1).

The key principles are set out in Table 5 which follows. This approach therefore represents a deepening of human rights considerations into state sector activity and a raised awareness among the general public about their rights.

98 These are: (1) The linking of decision-making at every level to human rights standards at the international level as set out in the various human rights covenants and treaties. (2) Identification of all relevant human rights involved, and a balancing of rights, where necessary. When balancing rights the priority should be given to the most vulnerable. (3) Accountability for actions and decisions, which allows individuals and groups to complain about decisions that affect them adversely. (4) Empowerment of individuals and groups by enabling them to use rights as leverage for action and to legitimise their voice in decision-making. (5) An emphasis on the participation of individuals and groups in decision-making. (6) Non-discrimination among individuals and groups through equal enjoyment of rights and obligations by all (HRC 2008a: 1). 


\section{Table 5. Eleven key principles of a Human Rights Approach}

\begin{tabular}{|l|l|l|}
\hline 1 & Universality & Human rights belong to all beings \\
\hline 2 & Non-discrimination and equality & Human rights are to be enjoyed by all \\
\hline 3 & Indivisibility & $\begin{array}{l}\text { Includes economic, social, cultural, civil } \\
\text { and political rights }\end{array}$ \\
\hline 4 & $\begin{array}{l}\text { Inter-dependence and inter- } \\
\text { relatedness }\end{array}$ & $\begin{array}{l}\text { Human rights reinforce and affect each } \\
\text { other }\end{array}$ \\
\hline 5 & Accountability & $\begin{array}{l}\text { Priountabits given to those facing special } \\
\text { obstacles to the realisation of human rights }\end{array}$ \\
\hline 6 & Attention to vulnerable groups & $\begin{array}{l}\text { All people have the right to participate fully } \\
\text { freely, effectively and voluntarily }\end{array}$ \\
\hline 7 & Participation & $\begin{array}{l}\text { As final arbiter the judiciary needs to be } \\
\text { independent and impartial }\end{array}$ \\
\hline 8 & Independence of the judiciary & Human rights must be guaranteed by law \\
\hline 9 & Rule of law and legislative capacity & Openness supports accountability \\
\hline 10 & Transparency & $\begin{array}{l}\text { People should be strengthened to shape } \\
\text { their own futures and support each other to } \\
\text { shape theirs }\end{array}$ \\
\hline 11 & Empowerment & \multicolumn{2}{|l}{} \\
\hline
\end{tabular}

Source: HRC (2008a: 2)

\subsubsection{New Zealand's Universal Periodic Review (2009)}

To recap on the UPR process, the reporting for New Zealand's human rights obligations is usually carried through periodic reports on the core human rights treaties (ICCPR, ICESCR, CEDAW, UNCROC, CAT, CERD and CRPD). As a further measure, the Human Rights Council, which had been established in 2006, has also mandated that the UN Human Rights Committee should carry out a Universal Periodic Review of each state on a four-yearly cycle. Consultation on the New Zealand draft was wide: over 70 community-based organisations and NGOs; the general public; and interested Māori, Cook Islands, Niuean and Tokelauan groups (HRC, 2008b: 5). The UPR report that was finally presented at the UN in May 2009 by the Minister of Justice Simon Power looked at those areas where New Zealand is surpassing or meeting international human rights standards and balancing this against current challenges in meeting these obligations. The report was reviewed by the Working Group on the Universal Periodic Review on 7 May 2009 and the New Zealand delegation was left with a list of 64 recommendations raised by 36 states that had commented on this country's report (UNGA, 2009b). The 
New Zealand Government considered these recommendations and reported back to the Human Rights Council on 7 July 2009 (UNGA, 2009c). The UPR review cycle therefore represents another layer of reporting that will help ensure the ongoing assessment of achievements against goals set.

\subsection{Summary}

What is clear is that the several documents and initiatives above do speak to each other in some content and concerns, even though some of the authors would not have known of the existence of all the reports. Despite their origin in different agencies - the HRC, Ministry of Justice, MFAT, independent ministerial report, select committee - common issues emerge and there is a build-up of similar strategies about what might address some of these problems. These issues include: affirmation for the work on inconsistent legislation; the need for the early mainstreaming of human rights into policy making, including training and better involvement of officials in this area; more parity between first and second generation rights; and improving human rights reporting. Along the way these initiatives have also had beneficial spin-off effects in raising human rights awareness across a number of groups in New Zealand - officials, NGOs, academics, the media and the public. The various initiatives also show an evolving process. There has been no linear progress, but instead trying one approach (e.g. Consistency 2000), then another, with different agencies in the lead. All the while broader structural problems and legislative issues have been addressed, the Human Rights Amendment Act 2001 being a major component of this. This fragmentation should not be seen as a bad sign. Oberleitner used a phrase about the proliferation of these institutions which could well be applied to the fragmented expansion of the New Zealand human rights framework:

Established ad hoc in response to concrete needs rather than as part of any master plan, such institutions have experienced sustained, yet mostly unplanned and uncoordinated growth and internal development (Oberleitner, 2007: 1).

This process is therefore not uncommon, and could even be a necessary phase on the road to a state moving towards robust human rights governance. It is further suggested in this thesis that this tweaking of the fragmented and inconsistent human rights system over the last several decades is slowly moving to a point where a more cohesive framework for officials to work from is emerging. However, key components of this are still not yet in place, and the next chapter examines these deficiencies and looks at 
possible solutions and how the complementarity of law+litigation/policy approaches could be helpful. 


\title{
CHAPTER 5: EMBEDDING A HUMAN RIGHTS APPROACH INTO THE STATE SECTOR
}

The evaluation and planning initiatives of the last chapter give many clues about how a human rights approach might be more effectively embedded into the state sector. However, the disparate ideas and recommendations have not been drawn together. This chapter looks at several factors that need to be clarified or improved in order to embed this approach more successfully: non-judicial approaches and early mainstreaming; where the locus of control for international human rights oversight should lie; the possible need for an inter-departmental group of officials; training civil servants; inconsistencies with the Cabinet vetting system; human rights education; state-level human rights governance; and some ideas for better implementation. The material in this chapter (and Chapters 6 and 8) relates to Phase Five about the more effective implementation of international human rights, particularly the theme of clarification. The several factors mentioned above are about showing how this effectiveness might be improved.

\subsection{Non-judicial approaches and early mainstreaming}

\begin{abstract}
A key result of the Re-evaluation of the Human Rights Protections in New Zealand report was the emphasis on policy-based vs court-based initiatives i.e. non-judicial approaches. The re-evaluation team had noted:

There are many different strategies by which a state may promote and protect international human rights. One approach is to permit the prosecution of human rights cases before domestic courts and international bodies. Another less adversarial approach is to integrate human rights into the state's policy-making processes. Both approaches are legitimate responses to the binding nature of international human rights law. Obviously, the policy approach depends less on the courts than the existence of good policy-making processes within government. Paragraph 5 of the Terms of Reference [of this report] requires the consideration of this non-judicial, policy-oriented approach to the promotion and protection of human rights. ... Policies which respect and reflect human rights are more likely to be inclusive, equitable, robust, durable and of good quality. Critically, such policies will also be less vulnerable to domestic and international legal challenge (Ministry of Justice, 2000a: 94, 95). ${ }^{99}$
\end{abstract}

\footnotetext{
99 Term of Reference 5 states: 'To re-evaluate the adequacy of current mechanisms and, if necessary, recommend changes that would ensure that international human rights obligations are taken into account in the development and implementation of government policy, practice and New Zealand legislation' (Ministry of Justice 2000a: 17).
} 
Other voices in New Zealand had been suggesting non-judicial approaches as well. At the $20^{\text {th }}$ anniversary of the NZ Law Commission in 2006 Sir Geoffrey Palmer noted that:

... the establishment of such bodies as the Human Rights Commission suggests a desire to develop principles in a non-litigious way that is more flexible and less confrontational, using the techniques of mediation and conciliation and non-court oriented methods of dispute resolution (Palmer, 2006: 23).

Two years later at the $60^{\text {th }}$ anniversary conference for the UDHR the Chief Commissioner Rosslyn Noonan stated that there was a history in this country of a 'pragmatic rather than legalistic approach' to implementation (Noonan, 2008). The reevaluation team also noted that the ad hoc growth of human rights in New Zealand had made it very difficult for these rights to be factored in at the desired early stages of policy making:

\begin{abstract}
New Zealand's law and institutions dealing with human rights have grown organically, largely in response to the adoption of the international standards we have helped to develop. ... As a consequence of fragmented growth, each agency is focussed on its own principal areas of activity ... there is little pressure or drive for strategic coordination and cooperation amongst the agencies ... the inefficiencies and loss of effectiveness caused by fragmentation was commented on by many. ... Today, international human rights are seldom taken into account early in New Zealand's policy-making process. For the most part the practice appears to be patchy, uneven and unsystematic (Ministry of Justice, 2000a: 6, 56, 95).

International human rights obligations are usually only factored into the government policy-making process at a relatively late stage [Cabinet vetting] with a consequent risk of disruption to that process. There are a number of practical steps that might be taken to encourage wider understanding amongst officials that early consideration of relevant international human rights norms will contribute to the development of sound policy proposals and a smooth policy-making process (Ministry of Justice, 2000a: 13).
\end{abstract}

These 'practical steps' included the 12 recommendations set out below that were produced by the team. They affirmed the need to fully mainstream a human rights perspective into policy making and to rationalise departmental responses to international treaty obligations.

1 All departments to review the arrangements which are designed to ensure that international human rights are integrated early in departmental policy-making processes. While it is anticipated that all departments will be assisted by the adoption of some of the following recommendations, given the varied nature of departmental work it is not expected that all recommendations will be adopted by all departments. The recommendations have particular relevance to those departments with policies and programmes with significant human rights implications, such as Justice, Social Policy, Health, Education, Labour, Children, Women, TPK, Treasury, MFAT, Police and Immigration.

2 A single consolidated human rights requirement for submissions to the Cabinet Office [i.e. addressing both national and international human rights].

3 A departmental senior official to be responsible for ensuring realistic, practical and effective arrangements are in place by which human rights are integrated into 
policy-making processes.

4 State Services Commission to revise generic policy-making guidelines so they give due regard to human rights.

5 Departmental policy-making guidelines to give due regard to human rights; such guidelines to list the international human rights instruments of particular relevance to that department's responsibilities.

6 Departments to ensure their staff, especially policy advisors, receive appropriate training in relation to human rights.

7 Departmental work programmes to identify the department's activities which are designed to enhance the promotion and protection of human rights.

8 In some circumstances, a departmental human rights impact assessment should be prepared in relation to a particular policy.

9 Departmental annual reports (or their equivalent) to list the international human rights instruments of particular relevance to the department and to include a section which outlines how the department's recent activities have advanced the realisation of human rights.

10 To establish a permanent, inter-departmental network of officials with particular responsibility for human rights.

11 To assign, with consequential resource allocation, primary responsibility for the preparation of periodic reports to Departments working especially closely to the relevant area e.g. ICCPR, CERD and CAT to Justice and ICESCR to the Ministry of Social Policy.

12 The Ministry of Justice, MFAT and Crown Law should review their overlapping responsibilities for the provision of advice on international human rights law and report to their Ministers with agreed proposals for resolving the issue (Ministry of Justice, 2000a: 104-106).

Geiringer and Palmer also looked at what the implications would be for New Zealand social policy making if a rights-based approach was taken. They noted that this approach is already 'a matter of binding international law', and that NZBORA in particular has 'forced' officials:

... to confront the implications of human rights commitments for policymaking, and this is reflected in Cabinet's decision-making processes ... Despite this, there remains considerable uncertainty within government as to what a rights-based approach to social policy might require ... (Geiringer and Palmer, 2007: 12, 13, 14-15).

However, it was written in 2007, a year before the HRC started their initiative 'The Human Rights Approach', which tries to clarify what this approach means, so work has been done on the area they suggested (see Section 4.3.2 for a discussion on this).

A further observation made by the re-evaluation team was that there was a strong linkage between social cohesion and a sound human rights environment. In their view integrating human rights early into the policy-making process tended to 'generate policies that ensure reasonable social objectives are realised by fair means' (Ministry of Justice, 2000a: 95). They saw that 'effective human rights institutions and a progressive 
human rights environment are at the heart of a nation's ability to maintain a peaceful and stable society' and that maintaining social cohesion and inclusion was 'an important aspect of welfare in the broadest sense' (Ministry of Justice, 2000a: 65, 95). The review therefore looked beyond the mechanics of the growing domestic architecture and reflected on the wider impact of a sound human rights policy environment. The HRC's action plan for human rights for 2005-2010 also noted that: 'Human rights are vital to peace, security and sustainable development worldwide. Poverty, conflict, violence and terrorism flourish where human rights are denied' (HRC, 2005a: 2). These comments from the re-evaluation team and the HRC link back to the point made earlier that the human rights system was a new (essentially international policy) framework that came on track after World War II, and which became one of the means of building a fairer society at both the international and domestic levels.

This sentiment is also echoed by Bradford and Scott in their work on robust economic governance:

There is often a link between persistent weakness of state institutions and the emergence - or re-emergence - of conflict. ... Achieving and maintaining security in the widest sense of the word is now an unavoidable part of promoting good governance and development. More often than in the past, the international community has to be involved in establishing and maintaining a security apparatus ... in fragile states which are incapable of doing it themselves: without it, the chance of a viable and lasting development programme underpinned by a viable and lasting [economic] governance regime is impossible (Bradford and Scott, 2009: 1, 8).

In this way robust human rights governance is the basis of a stable society, upon which robust economic governance can then be built. The two governances are therefore complementary and intertwined. ${ }^{100}$

The notion of a regulatory model is now briefly raised as it confirms the non-judicial approach already discussed in this section. When deciding about which route a particular international human rights issue travels into the domestic arena - law, policy or practice - it is obvious that some options such as legal interventions are more costly and it can be difficult for regulators to know whether to take a non-coercive or legalistic approach on issues. Michael Sparrow in his book on states managing compliance said

\footnotetext{
100 Bradford and Scott acknowledged that there are other governances (such as political governance), and noted that 'comprehensive governance reform in a fragile state must happen on both fronts, at the same time: political and economic' (Bradford and Scott, 2009: 25). However, they also noted that there is an ongoing complex intersection across a whole range of factors ('political, security and economic'). This thesis focuses on yet another factor, robust human rights governance, and suggests that until 'robust' vs 'fragile' features of each type of governance work is understood, it is not possible to fully appreciate the linkages between them.
} 
that 'regulators, legislators, and others' sometimes ask 'which approach - hard or soft works best' (Sparrow, 2000: xvi). He described 'graduated responses to noncompliance' and an enforcement pyramid with 'soft approaches' at the bottom and 'tougher sanctions (at the apex)' (Sparrow, 2000: 39). An adapted version of a regulatory pyramid from Ladley and Williams is shown below graphically in Figure 1.

\begin{tabular}{|c|}
\hline Specific law \\
\hline Mandatory general rules \\
\hline Enforced codes \\
\hline Aspirational codes \\
\hline Competition/consumer behaviour \\
\hline Public and private education \\
\hline Civic-minded - 'do the right thing' \\
\hline
\end{tabular}

Figure 1. Regulatory pyramid

Ladley and Williams stated:

There is a substantial body of literature which shows the complexity of achieving changes to citizens' behaviour and the even higher degree of difficulty in achieving changes to attitudes. Discussion about the use of law and regulation to achieve an objective often makes reference to some sort of sliding scale between education to achieve voluntary compliance, and enforcement to punish behaviour that deviates from the objectives (Ladley and Williams, 2007: 5).

The top level of 'state coercion' is 'generally the least effective (and most expensive)' (Ladley and Williams, 2007: 6). The layers therefore move from soft persuasive techniques through to punitive measures. The move towards a non-judicial policy-based approach fits well with this type of model that relies on lower, less costly, levels of the pyramid. It also links with the emphasis on human rights education that will be discussed in Section 5.7. Often the more people are informed and understand something - such as human rights issues - the more likely they are to respect them and comply voluntarily.

New Zealand has a basically rehabilitative approach to offenders, combined with a toughening of sanctions for some crimes. There is also a leaning towards non-coercive compliance in other areas. Because of this, a range of soft and hard strategies is used to enforce rules and influence attitudes and behaviours. Some societies such as the USA 
escalate up the pyramid by having highly rule-based systems. ${ }^{101}$ However, if the aim of a society is to try to get some voluntary following of the rules, in a rehabilitative vs punitive system this becomes self-enforcement needing less coercion. The system, however, can only be self-enforcing if there is transparency and people know what the rules are - which is why a rights-literate policy advisor network is essential. If advisors are the gateway for the implementation of rights to the general public then their knowledge about international treaty obligations needs to be exceptionally high. Then as a non-judicial approach deepens into the state sector, and in turn into civil society, the human rights approach is embedded at the bottom of the pyramid so that people take on its values and comply willingly.

A non-judicial approach which practises early mainstreaming can only occur when other factors are in place. The remainder of this chapter looks at various ways to strengthen the specific processes and mechanisms of New Zealand's human rights implementation, culminating in Section 5.9 which looks at specific ideas for better implementation.

\subsection{Locus of control}

The issue of locus of control is about who oversees human rights issues in the state sector. Over time responsibility for this has devolved more fully into the various departments concerned. Until the 1990s international human rights treaty obligations were largely managed and coordinated by MFAT and many staff within departments were unaware of international instruments and their associated obligations. MFAT has the chief oversight role of coordinating the preparation of periodic reports to the UN and the Ministry of Justice and the Crown Law Office are the main assisting departments in this process. At the NZ Diversity Forum 09 Chief Commissioner

\footnotetext{
101 For instance Anne-Marie Cusac documented the increasingly punitive approach to offenders in the USA: 'Over the past thirtyfive years the form of punishment in the United States has changed enormously. Our laws are harsher now. Convicts serve longer sentences ... Since 1973 the nation's imprisonment rate has multiplied more than five times ... One percent of our population is now in prison ... I noticed an increase in new weapons and machines for policing and prisons. The novel technologies, nearly all of them aggressive in purpose but coolly promising to "control" or "restrain", proliferated across the landscape of American justice, often with little regard for questions of whether or not such devices could kill those they were supposed to subdue. Advertising materials for many of these devices promoted the pain they would cause a disobedient or unruly inmate ... This understanding of the criminal personality as irredeemable leads us to punish harder and punish longer' (Cusac, 2009: 1-2, 3, 14). Where each state pitches itself in terms of the regulatory pyramid therefore depends on its 'core philosophy' in relation to punishment.
} 
Rosslyn Noonan suggested that the Minister of Justice should perhaps be the lead person in dealings with the UN Human Rights Council (he had just presented the UPR in May 2009). While the main oversight in this area has until now fallen to MFAT, it is not the agency responsible in New Zealand for the domestic implementation of international human rights treaties and the Chief Commissioner believed it could be timely to change that.

This lack of clear leadership was one of the deficiencies noted in the general discussion at the NZ Diversity Forum 09. In comments from the floor a number of points were raised: the need for the right department with dominant responsibility for undertaking the reporting process (there are multiple agencies involved with no domestic oversight); the responsibility for international human rights needs to be dispersed across and within departments; there is a lot of overlap in the work of the departments with seven treaties, five-yearly reporting periods, and overlaps in timing between agencies; there can be reporting fatigue for some of the smaller departments ; in general, the information is not presented as effectively and efficiently as it could be; and that there is no clear dominant agency, no one group of officials dedicated to multi-agency human rights issues.

\subsection{Human Rights Working Group}

The $10^{\text {th }}$ point of the re-evaluation team's recommendations is: 'To establish a permanent, inter-departmental network of officials with particular responsibility for human rights' (Ministry of Justice, 2000a: 105). In the previous chapter it was noted that the inter-agency working group that the Cabinet paper (Cabinet Office, 2001a) and Cabinet Minute (Cabinet Office, 2001b) endorsed was set up in 2002, but focused on helping the HRC develop a national plan of action instead of early mainstreaming. Because the group has since faded in a formal sense, there is now no official interdepartmental training for policy advisors. Also the State Services Commission did not eventually produce generic guidelines for the state sector as suggested in the fourth point of the re-evaluation team's 12 recommendations (Aspey, 2008: Personal communication). This result is one of the problems with the ad hoc growth of New Zealand human rights framework. An independent ministerial report is commissioned which made expert recommendations and these are taken seriously at Cabinet level. They start to be implemented, but then because of lack of resources the work of the 
group is re-prioritised (onto the then very important action plan) and it eventually fades. The need for such an inter-departmental group is still very important. It was noted in the general discussion at the NZ Diversity Forum 09 that although there were many experienced people in New Zealand across a number of treaties (CERD, UNCROC, CAT), there was no comprehensive approach to making these treaties realisable.

The establishment of such a group need not be expensive, nor should it be timeconsuming for those involved. A meeting of key cross-agency representatives could for instance meet every two months for two hours, and if one of the departments provided secretariat services the administrative aspect could be absorbed within the state sector. One issue, however, would be finding the right level for the group. Given CEOs and general manager levels would not be free to become involved in the level of detail required, and general policy analysts would not be senior enough to make significant decisions, a group at the senior policy advisor/line manager level might be most suited to take on this role.

A USA model and New Zealand public policy literature are now looked at as possible helpful aids for such a group, which might usefully be called a 'Human Rights Working Group'. (Note the discussion in Section 4.2.2 about the Cabinet direction that an 'interdepartmental working group' be established.)

\subsubsection{USA inter-agency model}

The USA has had an inter-agency group in this area and it is worth looking at their model to see if it could be useful here. Each country has a different political system, type of government and constitutional arrangement so this will affect the shape of any such group. In 1998 the Clinton administration established an Inter-agency Working Group on Human Rights Treaties, but it was disbanded by the Bush administration (HRC, 1998: 37). The Working Group had a wide-ranging brief including:

- Coordinating the inter-agency effort towards the ratification of international treaties

- Coordinating periodic reports to the UN

- Coordinating responses of the USA government to complaints concerning human rights violations submitted to the UN and other international organisations

- Developing mechanisms to ensure domestic legislation aligns with international treaty obligations

- Developing public education programmes about the main treaties (ICCPR, CERD etc)

- Coordinating an annual review of the USA reservations, declarations and understandings to human rights treaties

- Coordinating on other significant tasks e.g. liaising with Inter-American Commission on Human Rights and UN Special Rapporteurs (USA Government, 1998: 1). 
This is different to the New Zealand model where the above roles are spread primarily between the HRC, MFAT, the Ministry of Justice, the Crown Law Office and the Human Rights in Education (HRiE) initiative with relevant help from other departments as appropriate. The value of the broad-based USA model is that all aspects of the domestic human rights framework - treaty reporting, complaints, alignment of domestic law, education, reservations, national and regional human rights mechanism liaison could be looked at in total by a Human Rights Working Group comprised of individuals across the state sector and possibly the HRC. This would be a practical example of a whole-of-government model, which (if functioning effectively) would result in the complementarity of the law+litigation and public policy approaches.

\subsubsection{Joined-up government and the Coordinated State Agencies Goal}

This whole-of-government approach is about the problem of dealing with complex inter-departmental issues. This issue has already been taken up by public policy academics and the notion of joined-up government is starting to gain traction in the public sector. An article by Ryan et al examined 'managing for shared outcomes in complex policy cases', and inter-departmental networking on human rights issues could be classified as a complex undertaking. ${ }^{102}$ The authors felt that these types of collaborations were 'a significant challenge for public sector organisations in NZ but, even more, for the collective leadership of the public sector' (Ryan et al, 2008: 14). The approach focused on looking at "what works" rather than prescribing systems or models from the top-down or as context-free "best/good practice", (Ryan et al, 2008: 1). They stated that when a problem is multi-dimensional no single agency can deal with it:

As NZ public officials gradually figure out what "managing for outcomes" means, and especially "shared outcomes", they are progressively realising "we can't do this on our own" and that "we need to join up to get the results". The talent in their practical response has been to build their work on small, informal horizontal networks that flow between organisations (and sectors): these have the advantages of being energetic, flexible and responsive, while still having the access to human and other capital that comes with being part of larger, vertically-aligned formal organisations (Ryan et al, 2008: 14). 
In similar vein the State Services Commission has published guidelines (SSC, 2008) on the factors for successfully coordinating action among state agencies. A complementary document (SSC, 2004) is about agency leaders working towards shared outcomes. The first resource sets out a simple framework (using nine success factors) that agencies can use to coordinate their activity. ${ }^{103}$ The 2008 guidelines were produced in the context of the six Development Goals that the State Services Commission is working towards achieving. One of these six is the Coordinated State Agencies Goal: 'Ensure the total contribution of government agencies is greater than the sum of its parts' (SSC, 2008: 6). Their vision for this goal:

$\ldots$ is that government agencies coordinate their efforts using their expertise as appropriate, and are committed to shared outcomes where these help achieve the right results for New Zealanders. Agencies recognise that they need to work closely together and with partners to provide clear, joined-up responses to complex policy challenges and provide seamless services to the people who need them (SSC, 2008: 6).

The State Services Commission noted that: 'Internationally, government agencies are recognising that the policy issues they are addressing often transcend agency boundaries' (SSC, 2008: 7). They also raise the issue that governments are increasingly entering into international cooperation agreements, and human rights treaties certainly come under this category. Instead of different agencies working on the same problems in a vertical silo, horizontal cross-agency collaboration on a complex issue 'can develop targeted solutions based on a better understanding of the full scope of the issue, resulting in more effective interventions' (SSC, 2008: 8). Analysing the models set out in this field of research could be very fruitful for any Human Rights Working Group networking on human rights issues.

\subsubsection{Covenant obligation seminars}

Another solution for strengthening human rights coordination and awareness in the state sector could be to set up generic covenant obligation seminars that different sets of departments would attend according to their area of responsibility. The $11^{\text {th }}$ point of the 12 re-evaluation team recommendations was:

\footnotetext{
103 The nine factors are: 'The mandate for successful coordination: (1) Leadership commitment; (2) Ministers' and stakeholders' buy-in; (3) Defined and agreed joint outcomes. The systems for successful coordination: (4) Appropriate and documented governance and accountability framework; (5) Sufficient and appropriate resources; (6) Process to measure performance from established baselines. The behaviours for successful coordination: (7) Right representation, skills and competencies; (8) Organisational cultures that support coordination; (9) Shared culture, language and values' (SSC, 2008: 11).
} 
To assign, with consequential resource allocation, primary responsibility for the preparation of periodic reports to Departments working especially closely to the relevant area e.g. ICCPR, CERD and CAT to Justice and ICECR to the Ministry of Social Policy (Ministry of Justice, 2000a: 106).

It could be possible to take it a step further by developing a module on each of the core treaties (ICCPR, ICESCR, CEDAW, UNCROC, CAT, CERD and CRDP) which informs a cross-sector group of policy advisors from the appropriate agencies for that treaty about: the history of the treaty; New Zealand's obligations; a summary of this country's periodic reports submitted so far; developments on any reservations to the treaty; and areas of demarcation and overlap in responsibility for the treaty. These modules could be taught by specialists who are able to raise discussion points that come from topical cases about the treaty in Europe, the USA, Australia and New Zealand. They could also highlight areas of hidden or indirect discrimination relating to the treaty they are examining.

\subsection{Training officials}

The $6^{\text {th }}$ point of the re-evaluation team's recommendations was about greater crossagency training on human rights issues: 'Departments to ensure their staff, especially policy advisors, receive appropriate training in relation to human rights'. Other voices have added to this since then, including the Commonwealth Secretariat, the HRC in New Zealand, and the OHCHR. The Commonwealth Secretariat in its report on NHRI best practice emphasised the role of NHRIs in this type of training:

\footnotetext{
Specific training [about applicable norms and human rights standards] should be designed for members of the police, military forces, judiciary, legal profession and other members of society that have powers or responsibility relevant to human rights ... NHRIs can change the culture of government and its employees, the judiciary and the legal profession, the security forces and those in positions of power through training (Commonwealth Secretariat, 2001: 22, 23).
}

The OHCHR has linked strengthening the accountability of public officials as a key to upholding the rule of law, one test of robust human rights governance. They believed officials need to be trained in order to understand the rights they are upholding (OHCHR, 2007: 6). In May 2009 the Committee Against Torture gave its Concluding Observations on New Zealand's fifth periodic CAT report and mentioned the need for more human rights training. While they were pleased that training on human rights obligations is given to 'police recruits, prison personnel and armed forces', they were nevertheless concerned about the lack of training for immigration staff (UN, 2009: 2, 
3). A snapshot picture of the current training available in the New Zealand state sector (and through the HRC) is given below.

\subsubsection{HRC, Justice and MFAT}

The HRC, as the NHRI, is statutorily tasked with the function of general human rights education, but does not specifically offer training to government agencies at the moment because of lack of resources. However, the HRC is working with the Ministry of Justice on an ongoing basis to formulate human rights-related workshops for departments (HRC, 2008d: 2-3). Also through its Infoline the HRC does provide information on issues such as anti-discrimination and Treaty issues if requested by departments. The HRC's submission on the UPR report emphasised this area:

\footnotetext{
... the Commission recommends explicit government commitment to the full and effective incorporation of ratified international human rights standards in domestic legislation, in policy development and in public sector professional development and training (HRC, 2008b: 5).
}

The government department that takes the greatest cross-agency lead in human rights training is the Ministry of Justice, whose focus has been on ensuring NZBORA compliance in the state sector. To this end three documents have been produced to help policy advisors working with the Human Rights Act and NZBORA: The Human Rights Act 1993: Guidelines for Government Policy Advisers (Ministry of Justice, 2000b); The Non-Discrimination Standards for Government (Ministry of Justice, 2002); and Guidelines on the New Zealand Bill of Rights Act 1990: A Guide to the Rights and Freedoms in the Bill of Rights Act for the Public Sector (Ministry of Justice, 2004). It is this last document which points out to policy advisors that policy making occurs within the context of New Zealand's international human rights obligations. The Ministry also assists the Institute of Judicial Studies in education for judges about international obligations, runs a justice forum for officials from the state sector to discuss topical issues, and provides all internal staff with privacy training.

MFAT holds an internal course on 'Introduction to Multilateral Diplomacy', which includes a human rights element. In the past the HRC has organised courses for New Zealand's International Aid and Development Agency (NZAID) on human rights and development. MFAT are currently in the process of reviewing human rights training (Loose, 2009b: Personal communication). 


\subsubsection{Enforcement agencies}

Four enforcement agencies - NZDF, the Department of Corrections, the NZ Police and the Immigration Service of the Department of Labour - also have human rights training available to their staff. For instance in the NZDF all military personnel, as part of their basic training, have comprehensive training on the law of armed conflict, the four Geneva Conventions, the Anti-Personnel Lands Mine Convention, the Chemical Weapons Convention, and general human rights education. Further models are delivered two levels above basic training for commanders. They also provide 'Equity Training' which covers the 13 grounds of discrimination, exemptions and some of the background to the Human Rights Act. This is given to all personnel during basic training, and in all military promotion courses and in Unit briefs. NZDF Antiharassment Advisers also get comprehensive training on the Human Rights Act (Johnson, 2010: Personal communication).

The Department of Corrections currently trains new recruits in all policies and treaties during the initial training course for new Corrections Officers. This involves quite a lengthy session and covers all relevant information on the rights of prisoners within their care. They go over this area several times during refresher training and the department is in the process of writing new material with the 'duty to protect life' initiative that is currently being expanded (Amesbury, 2009: Personal communication).

Over 2004 and 2005 the NZ Police worked with the HRC to tailor their introductory package 'Making Human Rights Work' to operational policing needs. The resulting training was delivered nationally to police staff over 2006 and 2007. The purpose of that training was to enable staff to fulfil their responsibilities in helping the NZ Police comply with and apply the wider intent of the Human Rights Act and human rights principles. It built on other training initiatives on topics such as NZBORA, ethics and inclusiveness. The goals of the training were for participants to: be aware of the context for human rights; understand the basic elements of the Human Rights Act and the links to NZBORA; recognise International Human Rights Standards (IHRS) as they apply to policing; apply the Human Rights Act and principles internally, to police staff, and externally to their work with the public; and identify what they need to do to ensure that the organisation complies with and meets the wider intent of the Act. Since 2007 newly appointed staff (including probationary constables) have attended sessions as scheduled 
by their district, and ongoing refresher sessions are also provided. In the recruit training programme there are a number of areas where the treatment of individuals/rights of individuals is discussed. ${ }^{104}$ Training is also provided in relation to the Privacy Act 1993. The Police Privacy Officer currently trains all staff who are qualifying as Sergeants, Senior Sergeants and Inspectors at the Royal New Zealand Police College. The Privacy Officer also provides training around the country and at National Headquarters as and when it is deemed necessary (Wilson, 2009: Personal communication).

The Immigration Service of the Department of Labour stated that how much training an officer receives on conventions, treaties and relevant legislation depends on what the officer does. The 'average' immigration officer gets training on conventions such as the Hague Convention and sometimes UNCROC. The Hague Convention is looked at as part of their Adoptions Issues training and UNCROC is part of Student Policy training. Privacy Act 1993 and Official Information Act 1982 training is also available for all officers. Compliance Officers are responsible for humanitarian interviews prior to removal or deportation orders being made. They receive training on the ICCPR, conventions and protocols relating to the status of refugees, UNCROC and CAT. As Border Officers are responsible for turning people around at the border they receive the same training. Refugee Status Officers are also now well versed about relevant international instruments. They Immigration Service noted that with the Immigration Act commencing in 2010 they have made a commitment to staff and external stakeholders to cover more about human rights as part of the training for the new Act (Cheung, 2009: Personal communication).

The agencies just listed have very good internal training and the Ministry of Justice has produced useful cross-agency publications. There has been a real attempt to train policy advisors about the cornerstone pieces of human rights legislation - NZBORA and the Human Rights Act. The international reporting obligations are therefore a real driver for public sector work. However, a further level of generic cross-agency training on specific treaty obligations has not yet occurred, and the suggestion given in Section

\footnotetext{
104 This has included but is not limited to: Victims' Rights Act 2002; Bill of Rights Act 1990 and the related Practice Note on Police Questioning (Evidence Act 2006); Criminal Disclosures Act 1995; Domestic Violence Act 1995; Crimes Act 1961/Misuse of Drugs Act 1975/Arms Act 1983 - detention powers/processes; Mental Health (Compulsory Assessment and Treatment Act) 1992 detention powers/processes/treatment of patients; Responsiveness to Māori; Sudden death - cultural factors and awareness; Children, Young Persons \& Their Families Act 1989; and Ethics (Wilson, 2009: Personal communication).
} 
5.3.3 about covenant obligation seminars (or a similar initiative) could help this. A database of what human rights training is actually being offered by each agency would perhaps also be helpful, and that this could potentially be updated by a Human Rights Working Group.

Cross-agency training would also offer a useful connect between the macro-meso-micro levels outlined in Chapter 2. Officials could be given information on: (a) the broad principles underlying the human rights system; (b) the law and regulation level; (c) how this affects specific cases. Currently, it might be possible for an official doing 'small p' policy work to have very little interface with the 'big P' macro human rights system, but if the law+litigation/policy complementarity is strengthened it would advance human rights implementation much more effectively. At the moment there is not quite the inter-meshing where changes come through at that macro level, feed through laws and regulations at the meso level, and then down into specific cases involving an individual at the micro level. As this cascade is not entirely integrated, there is still more work to do in this area.

\subsection{Cabinet vetting system}

Some problems with the Cabinet vetting system in relation to human rights-related legislation are now examined. All new legislation is vetted against NZBORA, the Human Rights Act and the Privacy Act. The institution of this system, which came into effect after the passing of NZBORA in 1990, acted as a sea-change leading to the much wider impact of human rights across many sectors. There is also a Treaty vet, which will be discussed in this section. However, the re-evaluation team were critical of the negative orientation of the vetting process, particularly its legal vs policy focus i.e. a judicial vs non-judicial approach:

\footnotetext{
When legislative proposals are 'vetted', the exercise tends to have a negative orientation. Geared towards technical compliance, 'vetting' is designed to check that the proposal does not breach New Zealand's international obligations. It reflects a risk management strategy, the primary aim of which is to minimise the risk of legal proceedings. 'Vetting' and compliance are corollaries of the court-based approach to the promotion and protection of human rights. This approach is important but Paragraph 5 of the Terms of Reference [of this report] is based upon a less adversarial, policy approach to the realisation of human rights. While vetting has a negative orientation, the integration of human rights into policy is a much more positive approach to human rights implementation (Ministry of Justice, 2000a: 96).
}

The updated online CabGuide (Cabinet Office, 2010a) and Cabinet Manual (Cabinet 
Office, 2010b) contain instructions for policy advisors setting out the human rights implications of policy proposals and draft legislation in Cabinet papers. Bill of Rights vetting is carried out by the Ministry of Justice (for non-Justice bills) and the Crown Law Office for any Bills put forward by the Ministry and this is known as 'Section 7 vetting'. ${ }^{105}$ The CabGuide also noted that: 'Although the formal requirement in terms of section 7 is for a Bill of Rights report, in practice the vetting of bills at this stage also deals with Human Rights Act issues'. ${ }^{106}$ The CabGuide stated that any inconsistency with either NZBORA or the Human Rights Act must be pointed out 'before proposals reach the legislative or implementation stage' and importantly the advice asked departments 'to consider human rights issues in terms broader than the avoidance of discrimination'. 107 The key part under 'Human Rights Implications' in this section stated that Cabinet papers should include a 'paragraph on the consistency of the proposals' with NZBORA and the Human Rights Act which:

- states the nature of any potential inconsistencies identified (or states that there are none);

- note the steps to be taken to address the issues; or

- include information on any justifications for the policy infringing a right or a freedom.

The process is slightly different for Cabinet papers seeking to introduce a Bill. In this case under the heading 'Compliance' officials are asked to:

Indicate whether the Bill complies with each of the following, with reasons if the Bill does not comply (list each sub-heading):

- $\quad$ principles of the Treaty of Waitangi;

- rights and freedoms contained in the New Zealand Bill of Rights Act 1990 and the Human Rights Act 1993 (state the nature of any potential inconsistencies identified, or state that there are none; note the steps taken to address any issues, or include information on any justifications for the Bill infringing a right or freedom);

- $\quad$ principles and guidelines set out in the Privacy Act 1993 (if the Bill raises privacy issues, indicate whether the Privacy Commissioner agrees that it complies with all relevant principles);

- relevant international standards and obligations; and

- LAC Guidelines: Guidelines on Process and Content of Legislation, a publication by the Legislation Advisory Committee.

\footnotetext{
105 Section 7 of NZBORA states: 'Attorney-General to report to Parliament where Bill appears to be inconsistent with Bill of Rights. Where any Bill is introduced into the House of Representatives, the Attorney-General shall: (a) In the case of a Government Bill, on the introduction of that Bill; or (b) In any other case, as soon as practicable after the introduction of the Bill, bring to the attention of the House of Representatives any provision in the Bill that appears to be inconsistent with any of the rights and freedoms contained in this Bill of Rights'.

106 See http://cabguide.cabinetoffice.govt.nz/procedures/legislation/checking-human-rights-issues (accessed on 4 June 2009).

107 See http://cabguide.cabinetoffice.govt.nz/procedures/papers/sections-in-papers (accessed on 4 June 2009).
} 
Any moves to develop early mainstreaming initiatives will address issues at the initial policy stage rather than allow them to be raised as potential legal risks just as the matter is being presented to Cabinet. The contrasting negative and positive aspects of the two approaches can now be summarised. Negative vetting: Cabinet paper process of vetting legislative proposals; risk-management approach (minimising risk of legal proceedings); court-based; and technical legal compliance. Positive vetting: early integration of human rights considerations into the policy-making process; nonadversarial; policy-based; and focus on compliance with the spirit and intention of the Human Rights Act vs strict technical legal compliance.

The vetting process is therefore an important 'gate' for policy advisors to stop at and consider human rights implications, even if it is at a late stage. When a policy mechanism is put in place it therefore changes public servant behaviour i.e. they must work differently.

\subsubsection{Inconsistent vetting: Treaty, bill of rights, privacy, human rights}

Cabinet vetting (for either policy proposals or Bills) is therefore a late stage approach that needs to be complemented with early mainstreaming efforts. However, on closer examination it can be seen that vetting is carried out in different ways across topics: NZBORA vetting, Treaty vetting, privacy vetting and human rights vetting. NZBORA vetting is the most straightforward (and probably the strongest) because the Ministry of Justice is responsible and has a dedicated Bill of Rights Team carrying out this work on a daily basis. At the general discussion at the NZ Diversity Forum 09 it was noted that the Ministry of Justice vets 50-60 pieces of legislation a year and around 250-300 Cabinet papers and policy documents. This forms a significant component of their work, and as suggested above human rights vetting (against the Human Rights Act) would happen simultaneously when this team is checking for NZBORA consistency. However, this is a lot of pressure on one relatively small team of people.

In relation to Treaty vetting Matthew Palmer stated in 2008 his concern about this. The LAC Guidelines, ${ }^{108}$ the Cabinet Manual and the CabGuide all contain requirements 
about considering Treaty implications when developing draft legislation. He noted there are 14 departments who might be consulted about Treaty issues but that the key agencies are Te Puni Kokiri and the Ministry of Justice (Office of Treaty Settlements). However, for Palmer:

\begin{abstract}
There is a question as to how well all these requirements are enforced in practice. There is a great temptation for Ministers and officials simply to assert that no Treaty of Waitangi implications of legislation, or of policy proposals, have been identified or that they do not require action, without properly analysing whether that is right. ... Yet the rules for Cabinet decision-making give important signals to public servants as to what is important. The existence of explicit systemic requirements in relation to the Treaty for the last 22 years has, in my experience, had a significant effect on the day-to-day reality of executive government. It has greatly increased the extent to which officials think, and act as if, the Treaty of Waitangi has power in reality (Palmer, 2008: 223).
\end{abstract}

The same could be said for human rights vetting: it is difficult to gauge how seriously government agencies other than the Ministry of Justice and the Crown Law Office take this requirement. In 2000 the re-evaluation team were concerned that despite the requirement for departments to indicate whether Bills or regulations are compliant it 'generates a relatively superficial departmental consideration' and 'international human rights standards and obligations seldom receive the level of attention they deserve' (Ministry of Justice, 2000a: 214). However, as pointed out by Palmer in relation to Treaty vetting, its mere presence means these considerations are at least raised at crucial times in the late stage policy and legislation drafting processes.

Turning now to the privacy and human rights vets, the human rights vet is carried out simultaneously with the NZBORA vet by the Ministry of Justice and the HRC is not involved at this stage. Their role comes later once a Bill has been drafted. Section $5(2)(\mathrm{k})(\mathrm{iii})$ sets out their statutory discretion to look at proposed legislation:

\title{
Section 5. Functions of Commission
}

(2)(k) To report to the Prime Minister on-

(iii) the implications of any proposed legislation (including subordinate legislation) or proposed policy of the Government that the Commission considers may affect human rights:

Comparing this with the privacy vetting system, the Privacy Commissioner is statutorily obligated to carry out a similar role:

\section{Section 13. Functions of Commissioner}

(1)(o) To examine any proposed legislation (including subordinate legislation) or proposed policy of the Government that the Commissioner considers may affect the privacy of individuals, and to report to the responsible Minister the results of the examination. 
a counterpart administrative side in the Cabinet Manual that consultation should be carried out. Under 'Principles of Cabinet Decision Making' there is a section on 'Departmental Consultation'. Included in this is the statement that: 'Consultation may sometimes be needed with agencies that have an advisory role, for example, the Office of the Privacy Commissioner' (Cabinet Office, 2010b: Para 19). The more detailed information about departmental consultation explicitly stated:

\footnotetext{
Departments preparing papers must ensure that they consider the interests both of other departments and other government agencies including the Privacy Commissioner, Officers of Parliament - the Controller and Auditor-General, Office of the Ombudsmen and the Parliamentary Commissioner for the Environment - and consult them at the earliest possible stage (Cabinet Office, 2010b: Para 19).
}

Note the prompt for early consultation: in practice this means that the Privacy Commissioner is invited to comment during the drafting of policy or legislation and liaise directly with departments. Not only do they have this role, they have the primary responsibility for privacy-related vetting issues as there is no department that takes on this responsibility. This puts the Privacy Commission as an outside agency - an independent crown entity - in a unique and heavily responsible position. Blair Stewart in his paper about the Privacy Commissioner's legislative and policy monitoring role noted the proactive role of that Commissioner in liaising closely with departments to ensure privacy considerations are taken into account early in their processes (Stewart, 1995: 38). This is therefore a parallel process to the early mainstreaming of human rights. Because they are not included in this Cabinet Manual consultation list the HRC only sees Bills (very seldom policies) after they have been drafted and are ready to be presented to Cabinet.

At this point a practical suggestion is raised: that there should perhaps be early stage HRC vetting of Bills and policies (in the same way as carried out by the Privacy Commission), which would offer a counter-point view to that of any departments and thus achieve a more robust human rights vet. It would also give much greater traction to the early mainstreaming of human rights considerations in the policy-making process endorsed by the re-evaluation report. This could be as simple as their inclusion on the next Cabinet Manual consultation list so that officials are prompted to contact the Commission 'at the earliest possible stage'.

One possible problem with this suggestion is that it could compromise the HRC's role as an independent body; it would certainly have to be an advisory role. If the HRC were too caught up in policy development, or took too legalistic a viewpoint, then it 
would cut across its own mandate. Also, examining the privacy implications of new Bills and policies is a relatively small area, while looking at these across the whole range of human right issues would be a vast undertaking and the HRC is not necessarily resourced to do this at too early a stage. Realising this inconsistency, however, adds weight to the argument that what is really needed is a body such as a Human Rights Working Group and more thoroughly trained policy advisors. It is not possible in this research to delve too deeply into this issue, but instead it is raised as a potential area to help the early mainstreaming efforts. ${ }^{109}$

\title{
5.6 Concluding Observations
}

Apart from the issues raised so far in this section, what has been missing in the New Zealand domestic framework is an effective way of considering and then implementing UN treaty body feedback in the form of Concluding Observations. The growing domestic human rights architecture in New Zealand has been influenced by UN comment through the cyclical reporting process for the core treaties. The Concluding Observations give a historical picture over time about the UN's views on New Zealand's compliance or not with human rights obligations and help States Parties to prepare future reports. It is expected that national parliaments and relevant government departments will debate and assess Concluding Observations to ensure greater compliance. The UN recommends that they are disseminated widely among all levels of society, especially the judiciary and state officials. It is also expected that domestic courts consider ratified international human rights instruments, such as the two major covenants, as interpretive aids to domestic law. Michael O'Flaherty has endorsed their importance:

\begin{abstract}
Arguably, the issuance of concluding observations is the single most important activity of human rights treaty bodies. It provides an opportunity for the delivery of an authoritative overview of the state of human rights in a country and for the delivery of forms of advice which can stimulate systemic improvements. ... Despite their relatively recent emergence in treaty body practice [1980s onwards], Concluding Observations have been elevated to be the primary record of the finding and recommendations regarding each State Party under review (O’Flaherty, 2006: 1, 51).
\end{abstract}

\footnotetext{
109 For a useful similar discussion on how the structure and processes of government could help the state sector take a rights-based approach to social policy see Geiringer and Palmer (2007: 31-34). Their focus is, however, on analysing whether cabinet decisionmaking/legislative/judicial processes have a systemic bias against economic and social rights and not on the area raised in this research (the implementation of New Zealand's international human rights system).
} 
He also pointed out when clarifying the legal status of Concluding Observations that as they are 'advisory rather than binding texts' they are not legally binding on states (O'Flaherty, 2006: 32). However, O'Flaherty believed they do have 'special status', quoting the views of a former UN Human Rights Committee member, Martin Scheinin:

The treaty obligations themselves are, naturally, legally binding, and the international expert body established by the treaty is the most authoritative interpreter of the treaty in question. Therefore, a finding of a violation by a UN human rights treaty body may be understood as an indication of the state party being under a legal obligation to remedy the situation (O'Flaherty, 2006: 34).

O'Flaherty made the point that the 'process of dialogue' surrounding the Concluding Observations is 'notable for its non-adversarial nature' and went on to say that:

To confer a compulsive quality to the subsequent findings by the treaty body would be inconsistent with this model and is likely to meet with resistance from States and further unwillingness to participate in the reporting process (O'Flaherty, 2006: 36).

Concluding Observations are therefore a fairly non-threatening way of treaty body committees giving feedback to ratifying states, and because of the ongoing five-yearly periodic reports they have over time come to form (as O'Flaherty stated) a kind of dialogue or conversation between the UN treaty body committees and each of these states.

The following two sub-sections outline: a German response to taking Concluding Observations seriously in the form of expert meetings; and an HRC initiative related to CERD that could act as a useful model for dealing with the problem.

\subsubsection{The German response: expert meetings}

Each country deals with Concluding Observations in different ways. The equivalent of the HRC in Germany (the German Institute for Human Rights) holds expert meetings on the observations to help ministry officials, NGOs, parliamentarians and academics decide how to implement the recommendations in them. The meetings have the added effect of being educational as each of the representatives from these groups is able to hear different perspectives from other experts. It is also helpful to have cross-treaty issues dealt with at once. For example, two or three UN treaty body committees may make a similar comment on an issue in their Concluding Observations and a coordinated vs fractured response can be resolved at a joint experts meeting. The expert meetings idea is presented by the Institute as 'a tool of treaty implementation to the 
international human rights community' (Seidensticker, 2005: 5).

As noted by Seidensticker the examination of state reports has several purposes: external monitoring; preventive aspect; common, targeted goal setting by the treaty body and the state party; and self-evaluation by the state concerning the progressive realisation of the rights contained in the treaty (Seidensticker, 2005: 8). Combining the UN system with a national expert meeting model allows for 'ongoing dialogue between governments and treaty bodies at the international level and the human rights community at the national level' (Seidensticker, 2005: 12). This Concluding Observations expert meetings idea perhaps parallels that of the USA Interagency Working Group on Human Rights. Any such group - whether it is working on a largescale (about the overall human rights system in a country) or on a micro scale (about taking into account Concluding Observation comments) - is broadly operating in the area of more effective implementation and many of the processes at the macro and micro levels could perhaps be the same and streamlined.

\subsubsection{A New Zealand model: Implementation Monitoring Table}

An excellent 2009 New Zealand solution to Concluding Observation implementation tackles this problem in such a way that it could be a very useful model across treaties. It is such a clear idea that it could be used not only in this country but in other jurisdictions. Joris de Bres, the Race Relations Commissioner at the HRC, has developed a CERD Implementation Monitoring Table, where the Concluding Observations from the last periodic report are set out on a covering front page, followed by a table in the form below.

The table can be updated on a regular basis, and this means that by the time the next report is due all points have been noted and, if necessary, progressively implemented. If such a system were developed for all the core treaties, inter-departmental coordination on human rights would naturally increase as this idea requires that departments responsible for each covenant participate. A possible problem, however, is that such a system would need to ensure against paperwork proliferation and a tick-box mentality. This idea would also address the problem raised in the general discussion at the $N Z$ Diversity Forum 09 that Concluding Observations tend to go on the shelf until just before the next reporting round for a treaty and then there is an urgent message sent out from MFAT to departments asking what have they done to fulfil or implement the 
recommendations. It was noted during the general discussion at the forum that there is a lack of consistency about how reports are prepared and recommendations followed up.

\section{CERD RECOMMENDATIONS AND NEW ZEALAND GOVERNMENT RESPONSE}

\begin{tabular}{|c|c|c|c|}
\hline $\begin{array}{l}\text { Recommendation } \\
\text { number }\end{array}$ & $\begin{array}{l}\text { Department } \\
\text { responsible }\end{array}$ & $\begin{array}{l}\text { Comment and } \\
\text { Recommendation }\end{array}$ & $\begin{array}{l}\text { Government Response as at } \\
\text { August } 2009\end{array}$ \\
\hline 11 & Ministry of Justice & $\begin{array}{l}\text { The Committee notes that the } \\
\text { Government of the State Party } \\
\text { has not formally endorsed the } \\
\text { Human Rights Commission's } \\
\text { New Zealand Action Plan for } \\
\text { Human Rights, which also } \\
\text { refers to race relations issues } \\
\text { (art. 2). } \\
\text { The Committee recommends } \\
\text { that the State Party provide } \\
\text { more detailed information on } \\
\text { measures adopted to follow } \\
\text { up on the Human Rights } \\
\text { Commission's New Zealand } \\
\text { Action Plan for Human } \\
\text { Rights, regarding race } \\
\text { relations issues. It encourages } \\
\text { the State Party to adopt, on } \\
\text { the basis of the proposals } \\
\text { made by the Human Rights } \\
\text { Commission, its own Action } \\
\text { Plan for Human Rights. }\end{array}$ & $\begin{array}{l}\text { Cabinet decision in July } 2007 \\
\text { directed Chief Executives of } \\
\text { government departments to } \\
\text { consider priorities in the Action } \\
\text { Plan in their annual planning and } \\
\text { reporting processes and to } \\
\text { engage in dialogue with the } \\
\text { Human Rights Commission in } \\
\text { implementation of the Plan. No } \\
\text { separate government action plan } \\
\text { is envisaged ... }\end{array}$ \\
\hline
\end{tabular}

Source: Joris de Bres, Race Relations Commissioner, HRC

Chief Commissioner Rosslyn Noonan had also pointed out at the NZ Diversity Forum 09 that there is a need to start to identify key indicators (most of which already exist) to track standards implemented so there is no regression over time on issues, and this table model would also be useful in monitoring these indicators (Noonan, 2009).

\subsection{Human rights education}

The human rights training available at the present time in government agencies, however, only represents one level of human rights literacy. For a human rights approach to seed into other parts of society - NGOs, academics, the media and the public - wider human rights education needs to be available. 
The importance of human rights education was set out in the UDHR in $1948 .{ }^{110}$ It took over 50 years for the UN to develop the World Programme for Human Rights Education in 2004, which followed on from the UN Decade for Human Rights Education between 1995-2004 (UN 2004). The programme is based on a number of phases with the first involving a Plan of Action for Primary and Secondary School Systems (2005-2009). This rights-based approach to education not only ensures that there is respect for all in the school community but that the curriculum and teaching methods are conducive to the learning of human rights. That is, human rights education is not a small confined area of the syllabus, but a background to the entire way teaching is carried out and school life is lived. This echoes the point made in Chapter 1 that the human rights project is at the 'heart' of the way government is carried out in New Zealand.

Since 2003 a cooperative venture in this area has been developed - the Human Rights in Education (HRiE) initiative - founded on the principles of both the UDHR and UNCROC. The initiative was launched by three NGOs (Amnesty International, the Peace Foundation and the Development Resource Centre), as well as the HRC and the Children's Commissioner. The HRiE is described as: 'a collaborative initiative for better education and effective citizenship, by developing schools and early childhood education centres as communities that know, promote and live human rights and responsibilities'. ${ }^{111}$ With children being taught human rights principles at school, there is not only a top-down approach to this education, but a bottom-up process where they are encouraged to explore their own basic instincts about fairness and justice. They can then link this to the core ideas contained in the international covenants they learn about.

There is a close connection between the HRiE and the New Zealand Curriculum (launched in November 2007), which specifically mentions human rights in its purpose, aims and content and takes a rights-based approach to education (Ministry of Education, 2007: 1). The initiative is informed by work done by Canadian academics which showed that explicitly teaching human rights will result in a range of benefits including higher self-esteem, mutual respect, less bullying and truancy, better learning and ultimately more responsible citizens (Covell and Howe, 2007, 2008). Part of the

110 Article 26 of the UDHR states that education should be directed to 'the strengthening of respect for human rights and fundamental freedoms'.

111 See www.rightsined.org.nz/index.php/hrie/what-were-about.html (accessed on 3 December 2009). For a further discussion on the initiative see Simpson (2009). 
premise of UNCROC is that children are citizens (see also Amnesty et al, 2007: 27-28). The HRiE initiative also aims to develop children as future citizens i.e. those who understand the dual nature of rights and responsibilities.

Mirroring the idea of policy advisors taking a human rights approach in their work, teachers are now encouraged to do this in schools. Through the HRiE initiative they are being shown that the school is already a human rights environment so applying such a lens is merely making apparent what is actually happening i.e. schools exist to fulfil the human right to an education. However, schools are often overloaded workplaces, with teachers being expected to be at once educators, social workers and now possibly human rights advocates. The Canadian studies show, however, that when they encouraged this approach in classrooms teachers found management of the students easier and their job satisfaction higher.

A year after the HRiE initiative was established the HRC produced Human Rights in New Zealand Today which noted that human rights education is 'much more than providing information about human rights' and is rather about 'creating an environment where human rights are respected' (HRC, 2004a: 364). The report raised current multiple problems with the provision of education in this country: that Māori, Pacific and disabled people and low-socio-economic groups had low participation and success rates; standards of education were not always good for those in isolated schools, poorer areas or for disabled children; and children continued to be discriminated against, bullied and harassed because of race, disability, sexual orientation and gender (HRC, 2004a: 279). Following on from this the HRC also established the Right to Education Framework: He Tapapa Matauranga in 2004 (HRC, 2004b). Four standards and nine criteria were developed to monitor the right to education and schools can assess their performance against these.

In 2007 another multi-agency initiative emerged to tackle the issue of human rightsbased education. The HRC in collaboration with Amnesty International and other agencies produced a report on building human rights communities in education (Amnesty et al, 2007). The aim of the report was to introduce:

... the concept of early childhood education centres and schools as human rights communities. By human rights communities we mean places where children and young people know their rights, acknowledge their responsibilities, and respect the rights of others. In this model the right to education for every child and young person is fully realised, learning is ensured, individuality and diversity are respected and there is 
freedom from violence, bullying and harassment (Amnesty et al, 2007: 3).

Because children and young people are especially vulnerable to human rights abuses at home and school, this initiative was set up so schools and early childhood centres could be places where they can realise their rights. ${ }^{112}$ A key point of the report was that it recommended that 'early childhood education centres and schools explicitly meet New Zealand's human rights obligations' (Amnesty et al, 2007: 7). The duty to meet these international obligations is therefore taken down one level from state agencies and into the frontline of education providers. It also extends the notion of human rights communities deep into civil society, thus layering three levels of such communities as seen below: international, national and local. This concept of human rights communities could be extended at the local level to include workplaces (at least state sector agencies), and universities and other training organisations such as Industry Training Organisations (ITOs) and training colleges. Three levels can therefore be envisaged:

1. International human rights communities (UN, international NGOs, regional mechanisms such as European Commission on Human Rights)

2. National human rights communities (domestic governments and NGOs)

3. Local human rights communities (workplaces, universities, schools and early childhood centres, ITOs, training colleges).

One positive aspect therefore of the move to get human rights-based education initiatives established is that a clear route is opened from the international human rights treaty level down through to people on the ground. UNCROC is an international treaty ratified by New Zealand and the obligations are reported on by state agencies. Schools (teachers, boards and parents) are now required to be aware of the rights of the child set out in this instrument, and as these initiatives strengthen children will become aware of and more fully able to realise these rights. New Zealand has taken a layered approach to human rights education and it appears to operate vertically (from pre-school through to university, from state sector down to civil society) and horizontally with cross-agency (and therefore collaborative) developments.

\footnotetext{
112 The report identified seven aspects of a child's right to education: 'The right to free education; the full realisation of the right to education for specific groups such as Māori, Pacific peoples, disabled people and those from poor communities; the right of the child to education regardless of legal status - denied to children of parents without official immigration status; the right to an acceptable standard of education; the right of children to "enjoy his or her own culture, to profess his or her own religion, or to use his or her own language" [from Article 30 of UNCROC]; the right to be safe from discrimination, bullying and harassment; and the availability of systematic human rights education provision' (Amnesty et al 2007: 9).
} 
This broadening and deepening of human rights education into all sections of society is an example of more clarity (a Phase Five theme) as the mechanisms and evolving structures establish. More specifically, in relation to the overarching theme of the thesis, rights are able to travel down through the international frameworks, into the domestic state sector, and be realised by the children (as individual rights-holders) who are protected by UNCROC. The training of policy advisors and general human rights education therefore become the twin arms of the attempt to instill a human rights approach into the state sector and deeper into civil society.

Another positive aspect relates to and confirms the link between human rights and social cohesion. The concept emerging out of the move towards human rights-based education is the possibility of rights-respecting classrooms/schools/communities helping to develop rights-respecting citizens. The report about building human rights communities in education also echoes the point about the early mainstreaming of policy work:

\footnotetext{
The combination of ethnicity, poverty and educational disadvantage poses a severe risk to social cohesion in this country [and there was a need to] move beyond the rhetoric of children's rights to the mainstreaming of a human rights perspective into all public policy (Amnesty et al, 2007: 10).
}

As well as research into human rights education at the school level a new trend has arisen in the last 20 years of multi-disciplinary research in universities and two examples exist in Australasia. The Australian Journal of Human Rights is published by the Australian Human Rights Centre (Forster and Morris, 1991 ongoing). The aim of the journal is to raise awareness of human rights issues in Australia and monitor developments in the area as they arise. Human Rights Research is a New Zealand journal produced by the Victoria University Human Rights Programme (2003 ongoing) as a result of a human rights symposium held at the university each year. Both the Australian and New Zealand journals have contributors from a wide range of disciplines: history, philosophy, religious studies, education, sociology, criminology, commercial law, political science and law. The public policy field has been noticeably absent from the contributions to this journal. Traditionally there has been much written on this topic by legal academics, and this cross-discipline approach will also strengthen this subject outside that area.

Human rights is becoming an increasingly inter-disciplinary topic. As government department staff become more rights-literate, academics continue to explore this topic 
within their disciplines, and NGOs input their perspective into the discussion, there will be a growing body of literature with more connectivity.

\subsection{Human rights governance level}

Having now examined the various aspects of embedding a human rights approach into the state sector, what is missing is a 'human rights governance level'. If this was operating well it would unite the law+litigation and public policy fields in an attempt to more effectively implement rights. This would result in complementarity where human rights become a central part of the fabric by which policy decisions are made. Even for New Zealand, with its good human rights framework, it would seem that the public policy field needs reviewing to better integrate aspects of this large human rights field that sits to its side and is even influencing the very nature of the state. As noted earlier, it was a post-war ambition to create an entirely different type of state ever: a human rights compliant state.

If the human rights field can be conceived of as a set of underpinning principles in the state sector, as previously discussed, it could be necessary to have:

- both the public policy and human rights fields prioritising early mainstreaming efforts, including the trend to use policy-based approaches to implementation

- public policy tools formally used in the implementation of international human rights

- more case studies and examinations which bridge the two fields: public policy and human rights

- public policy academics, researchers and practitioners perhaps becoming involved in the international human rights implementation area in the same way they currently support areas such as education, health and environmental issues.

These suggestions envisage a future different relationship between the law+litigation and public policy fields, and of those fields to the state sector. The result of this complementarity could be an emerging area of theory and practice in its own right. 


\subsubsection{Towards a four-fold domestic human rights framework}

A tri-fold international human rights framework has so far been suggested: organisational, legislative and guidance (see Table 2 in Section 3.2.2). The structures of the UN, the international law system, and the way the UN guides states about human rights have developed into this three-tiered system. Similarly a tri-fold domestic human rights framework has been outlined: organisational, legislative, policy-based (see Table 3 in Section 4.2). Human rights institutions have been set up, laws enacted, and nonlegislative approaches are being explored. The development of an additional fourth level - state-level human rights governance - would perhaps be parallel to the UN guidance level in the international arena (also see Table 3). This fourth level would also be identified by a good complementarity of law+litigation and public policy approaches. This guidance level has come into place internationally precisely because the equation 'treaty ratification $=$ improved human rights' obviously does not work. As shown by this research it does not work domestically either. However, it has also shown that by looking carefully at the specific processes and mechanisms of the New Zealand's human rights framework there are still ways to strengthen the implementation of ratified treaty rights, and these are discussed in the next section.

This four-fold framework relates to all three macro-micro-meso policy levels of Section 2.2. For instance, the organisational level (institutions, ministries and agencies) and the human rights governance level operate at the macro level of providing underlying principles. The law+litigation/policy areas, on the other hand, operate at the meso level because this is the level of law and regulation which gives standards against which to judge micro instances e.g. a particular child's right in a particular case.

\subsection{Better implementation}

As mentioned in Chapter 1, it is not within the parameters of this research to make recommendations. However, this section highlights several areas that could possibly be researched further, culminating in the idea of an effective Human Rights Working Group and what this might 'look like'.

What was clear from Chapter 4 is that the several planning and evaluation initiatives do speak to each other at times, even though some of the authors would not have known of 
the existence of all the reports and despite their origin in several different agencies. Common issues did emerge and there was a build-up of similar strategies about what might address some of these problems. However, what has become obvious from the review of these initiatives is that some of the resulting recommendations have become 'lost' in the system. A type of 'bureaucratic stickiness' can occur when multiple agencies are involved so it is not surprising that carefully considered solutions vanish without implementation. Reports are also commissioned or written without any previous knowledge that related agencies have carried out parallel work and arrived at similar conclusions. Work done at the parliamentary level can also be isolated from that carried out by departments.

One possibility is that a Human Rights Working Group could be responsible for keeping an ongoing record of past and any future key recommendations from major reports in the human rights area so they do not become lost. Resources permitting, this could over time be expanded to include major reports from the NGO sector. Another role for such a group could also be to keep an annually updated database of the human rights training available by the HRC and each government agency. Once a clearer picture has become available of what is currently in place, some streamlining should be possible to avoid duplication of effort.

To summarise, some of the outstanding issues are:

- International (UN, Commonwealth Secretariat) and national voices (the HRC, the re-evaluation report) are being ignored if mechanisms such as Concluding Observations are not being taken as seriously as they could be, and the recommendations of evaluation and planning reports carried out over a number of years are not being implemented.

- There is no overarching body or agency responsible for the breadth of human rights implementation similar to the USA Inter-agency Working Group on Human Rights.

- Human rights training is happening in key human rights-related departments, but there is no coordinated cross-agency training for instance on generic treaty information. 
- Research already carried out in other parts of the state sector (e.g. the State Services Commission model of cross-agency coordination) is not being utilised to help the complex problem of human rights coordination.

- The Cabinet vetting is being inconsistently applied, with the key human rights agency (the HRC) possibly being left out of the loop in a vital way.

Table 6. Potential role of a Human Rights Working Group

\begin{tabular}{|c|c|}
\hline STRUCTURE & $\begin{array}{l}\text { Modeled perhaps on similar groups in other jurisdictions e.g. the USA } \\
\text { Inter-agency Working Group on Human Rights } \\
\text { Use the State Services Commission cross-agency coordination model or } \\
\text { public policy joined-up government model, for instance, to help operational } \\
\text { aspects } \\
\text { - } \quad \text { Keep an ongoing summary of the key recommendations of major human } \\
\text { rights reports } \\
\text { Decide which department should be the lead agency in the area i.e. } \\
\text { reviewing MFAT having the main domestic oversight for the treaty } \\
\text { reporting process, and who should represent New Zealand at UN fora }\end{array}$ \\
\hline TRAINING & $\begin{array}{l}\text { Keep an annually updated database of human rights training available } \\
\text { through the HRC and government agencies } \\
\text { Possibly provide cross-agency training in the form of covenant obligation } \\
\text { seminars }\end{array}$ \\
\hline $\begin{array}{l}\text { CABINET } \\
\text { VETTING } \\
\text { CONSISTENCY }\end{array}$ & $\begin{array}{l}\text { - Carry out an audit or examination of Cabinet vetting systems across } \\
\text { NZBORA, Human Rights Act, Privacy Act and the Treaty, with the } \\
\text { possibility of including the HRC in that process. This could be as simple as } \\
\text { the Commission's inclusion on the Cabinet Manual consultation list so that } \\
\text { officials are prompted to contact them at the earliest possible stage }\end{array}$ \\
\hline $\begin{array}{l}\text { CONCLUDING } \\
\text { OBSERVATIONS }\end{array}$ & $\begin{array}{l}\text { - Look at models for implementing Concluding Observation } \\
\text { recommendations, including the HRC CERD model and the German expert } \\
\text { meeting system idea }\end{array}$ \\
\hline
\end{tabular}

Any classic multi-agency problem would almost certainly result in an interdepartmental network of officials. Table 6 above takes this idea as a starting point (suggesting a Human Rights Working Group), and collates the ideas contained in this 
chapter which could all be carried out as part of the role of such a group. ${ }^{113}$ This multifaceted approach should ensure a greater overall traction of human rights into government policy making and ultimately more human rights compliant laws and policies. If this approach was taken this should also enhance the Phase Five theme of clarification because the 'processes' for effective implementation will become much clearer over time.

\subsection{Summary}

The analyses that have been carried out in this area show a willingness to look at the root causes of problems and address them e.g. the Cabinet vetting process is too far down the track to be first thinking about human rights considerations. In particular, policy advisors need increased training so they are taking a rights-based approach right at the outset of the development of any new laws and policies. Models from other disciplines such as public policy, and other jurisdictions such as the USA, are now available for dealing with cross-agency coordination, which will be particularly helpful in the complex area of inter-departmental human rights networking. German and New Zealand models are also emerging for better implementation of Concluding Observation recommendations. A stronger Cabinet vetting system including a greater role for the key agency in the area (the HRC) could help deepen a human rights approach into the state sector. Understanding regulatory and core punishment models could also help to analyse the trend towards non-judicial, softer, non-coercive approaches. However, none of these ideas has been investigated, or not looked at fully, because there is no Human Rights Working Group in existence. Implementing some or all of these ideas could create a unifying core to a currently quite ad hoc human rights system.

\footnotetext{
113 Geiringer and Palmer also suggested some kind of 'capacity' be developed in the state sector in relation to 'mainstreaming a rights-based approach to social policy'. In their view: 'The key requirements for establishing this capacity are: a willingness at senior levels in one or more departments to adopt a rights-based approach to social policy issues (along with other approaches); understanding of social policy and ability to engage in social science analysis; a critical mass of individuals to sustain an ongoing capacity; high-quality legal skills and experience in applying legal analysis to policy issues characterised by fluid and flexible parameters; sufficient allocation of funding to ensure that the capacity is of sufficient quality to be credible and sustainable' (Geiringer and Palmer, 2007: 34). While their idea is focused on some kind of social policy capacity, it could be seen as complementary to the idea of a Human Rights Working Group because this group could have sub-committees in various areas (e.g. justice and human rights, Treaty and human rights, foreign policy and human rights, social policy and human rights) or across certain departments.
} 
Although there is a legislative (law+litigation) bedrock to human rights protection, this is not enough (even for first generation rights). The human rights endeavour envisaged a changed role of government, but as has been shown it also results in a changed relationship of the public servant to government given they have a crucial international legal protection role. With public policy a policy or mechanism is implemented which ultimately shapes state behaviour, the behaviour of officials and that of citizens as well - sometimes (as in the case of human rights) even shaping values. As the human rights endeavour as a set of underpinning principles has such a large effect, it is all the more important that the mechanisms and processes by which rights are implemented through the state sector are sound and efficient and employing all possible approaches and tools (both legal and policy i.e. complementarity).

It is now possible to answer the first research question: 'How have human rights considerations been integrated into the policy environment, and does this policy area align with the law+litigation approach to achieve complementarity of these fields'? A descriptive theory has developed in this thesis which shows the evolving integration of human rights into domestic policy, and although there is no full alignment with this field and that of law+litigation, the threads are there for it to happen over time. This research suggests that the field of human rights has become increasingly important in the policy environment because of the pivotal role of policy makers as the gate-keepers of New Zealand's international human rights protection. Another reason is because independent sources (the re-evaluation report, the HRC national plan of action 20052010, and the CabGuide) have identified early mainstreaming as essential to the more effective implementation of international human rights.

The diagnosis has therefore been given strongly; however, making the necessary changes is an ongoing task for the state sector. This research has shown that change in this area is an evolving process and one that is by no means as robust as it could be. Having said that, the 60-year build-up of human rights institutions, laws, policies and practices only started to be evaluated in the mid-1990s and this took a further 10 years to complete and the planning phase since 2005 is only five years old. As with many other areas on the government's programme, this issue is a 'work in progress', but if successful it would be a key part of the progress towards robust human rights governance. 
However, having discussed the benefits of greater collaboration the question needs to be asked about whether this is fully the answer. The problem may be systemic, and therefore better collaboration would be wasted if underlying resource and leadership issues are not resolved first. Individual agencies with highly developed human rights policies could perhaps effectively carry out reporting requirements and other obligations anyway, thus avoiding any duplication of effort arising from an inter-agency approach. A solution is therefore needed where individual agencies are working optimally on their own, where there is adequate resourcing and effective leadership generally (whether this is through a Human Rights Working Group or not), and where collaborative efforts actually enhance more effective implementation of human rights through the state sector. This raises the point too that enhanced collaboration and policy approaches only go so far. Another factor will be raised in Chapter 6: that the alignment of first, second and third generation rights also needs to occur for effective implementation. However, if this alignment took place and indigenous rights were to be incorporated, then the greater complementarity envisaged would be beyond the responsibility of professional public management. The larger holistic blending of law+litigation, the policy field, and rights balancing (with its philosophical and ideological underpinnings) would possibly need to be managed at another level, and this is where the notion of a human rights governance level (more fully developed in Chapter 7) could be helpful.

This chapter has looked closely at embedding a human rights approach into the state sector and answered the first research question about complementarity. Before answering the second question about what effectiveness would look like, Chapter 6 turns to two important issues in the current New Zealand human rights discussion: raising the status of both second generation (economic, social and cultural rights) and third generation (Treaty) rights. 


\section{CHAPTER 6: RAISING THE STATUS OF SECOND GENERATION RIGHTS AND THIRD GENERATION (TREATY) RIGHTS}

Elevating the status of second and third generation rights is the focus of this chapter. The status of second generation rights is a large and complex topic and would require a separate research project in its own right. Here the broad issues are raised to show how they are located within the wider domestic human rights framework, but also to situate the discussion in some overseas literature. Section 6.1 of this chapter illustrates the fifth phase of New Zealand's human rights history, with its three aspects of clarification, education and cooperation. This section clarifies how second generation rights could be implemented more effectively by looking at the experience of other jurisdictions, and this necessarily involves a re-education or re-thinking about this problem by taking account of these perspectives. There is also a cooperative effort on the part of the UN, the international organisation of NHRIs and the HRC in New Zealand to continually monitor the progress of the realisation of these rights. This section also contains a summary of potential legal and policy ideas that could be explored in the future.

Third generation rights are group or collective rights. Section 6.2 of this chapter looks at the three parts of the indigenous rights protection triangle: the Treaty of Waitangi, the UN Declaration on the Rights of Indigenous Peoples and a Human Rights Approach. The growing recognition of the Declaration domestically and internationally means a sharp lens has now been focused on its relationship with the Treaty and, in fact, how it can act as a tool to understand the human rights dimensions of the Treaty better. It is believed that the core principles underlying the Declaration are the same as those underpinning the Treaty. The Human Rights Approach is used in all of the HRC's policy work, and the Declaration is also now a reference point in this work. This approach applies particularly to the Treaty because the Commission is under statutory obligation to promote a better understanding of the human rights dimensions of the Treaty and its relationship with domestic and international human rights law.

The Treaty and the Declaration may not necessarily be viewed as human rights documents, but this chapter shows that they elevate both collective and individual rights 
and advocate a balance between them instead of a polarised tension. This work on linking both the Treaty and the Declaration to human rights is also consistent with the fifth phase of New Zealand's human rights history, the more effective implementation of international human rights standards. This chapter also shows very good examples of all three parts of this phase: clarification, education and collaboration. It will be shown that much has been done in the last few years to clarify the application of the Treaty and Declaration to human rights, education about the Treaty is ongoing, and attempts to penetrate the Treaty into the machinery of government (central and local) have necessarily involved cooperation.

\title{
6.1 Second generation rights
}

Interspersed throughout this research has been mention of this country's ongoing efforts to raise the status of second generation rights, a journey started by Prime Minister Peter Fraser with the drafting of the UN Charter in 1945, and with attempts to find nonlegislative gateways for these rights to travel through. The Human Rights in New Zealand Today report stated:

\begin{abstract}
Although New Zealand is not flawless, the report shows that we have most of the elements essential for the effective protection, promotion and fulfilment of human rights; democracy, the rule of law and an independent judiciary free of corruption; effective structures of governance; specific processes for human rights and other forms of accountability; recognition of particular groups and individuals; and active, involved, diversely organised citizens ... as individual New Zealanders we are generally free to say what we think, read what we like, worship where and when we choose, move freely around the country and feel confident in laws that protect us from discrimination and the arbitrary abuse of power (HRC, 2004a: 378).
\end{abstract}

However, the types of rights mentioned above are largely civil and political and the report conclusion identified the several outstanding pressing issues in the economic and social field which have already been mentioned. ${ }^{114}$ It is clear then that much more work needs to be done in this area and the Commission has specified the better provision of second generation rights as a key area of future work. It is also timely for the HRC to focus on these rights as they themselves have noted that other countries have taken proactive approaches to handling these rights. They cite, for instance, that these rights have been reflected in new constitutions for Denmark, Norway, Mongolia and Peru, and 
that in 2004 the UK Joint Committee on Human Rights published a detailed report on the implementation of the ICESCR in the UK (HRC, 2005b: 12). ${ }^{115}$

At the outset of this chapter it is suggested that New Zealand's commitment to ensuring fourth generation (environmental and ecological) rights is perhaps stronger than it is to second generation rights, possibly because the latter seem in the 'too hard basket', with perceptions of huge policies, programmes and associated costs needed to implement them adequately. There is wide public concern about and support for the recognition of this fourth type of rights; however, as has been seen in recent years, protecting environmental rights is also costly, for example the Emissions Trading Scheme and Kyoto Protocol commitments. Third generation (group, collective or solidarity) rights are also often at the forefront of the media through Treaty-related issues.

The first/second generation debate has often been split along the North-South (or developed/developing countries) divide. Developing nations have been critical of the West for too highly favouring civil and political rights at the expense of committing to real policies to ensure the realisation of second generation rights. ${ }^{116}$ On the other hand the West has sometimes been sceptical that developing nations focus on the urgency of providing subsistence rights (e.g. food, water, housing) as the reason not to fully protect the civil and political rights of their citizens (NZ House of Representatives, 2005: 15, 21). In 1996 a group of 29 international law experts met in Holland to consider the more effective implementation of the ICESCR. In their view economic and social rights could 'be realised in a variety of political settings', there was 'no single road to their full realisation', and that 'successes and failures have been registered in both market and non-market economies, in both centralised and de-centralised political structures' (International Commission of Jurists, 2006: 4). The group urged states to provide minimum subsistence rights despite their economic circumstances.

This links to a long-standing debate about the difference between first and second generation rights: the former have tended to occupy a 'second class status' (Beetham, 1995: 41). According to human rights theorist David Beetham, second generation rights

115 For this report see UK Parliament (2004).

116 This focus has been because civil and political rights were the first to be protected in the West. For instance, the American, French and English Bills of Rights were about protecting life, liberty and property. Second generation rights have typically not been protected until the development of social welfare legislation in the late 19th and early 20th centuries in developed states, or until the advent of international instruments such as the UDHR and the ICESCR. 
can be seen more as basic welfare goals than rights. ${ }^{117}$ Civil and political rights are easily classed as rights because they are 'definable in justiciable form', it is 'clear who has the duty to uphold or implement' them, and they can be linked to a 'responsible agency' which has the capacity to fulfil their obligations (Beetham, 1995: 42). He said some argue that second generation rights 'do not satisfy these conditions' (Beetham, 1995: 42). However, he claimed there is value in keeping up the pressure for human rights in the economic and social area as they sound more authoritative than 'basic welfare goals', they help those in poorer countries argue their case, and they 'emphasize the obligations of governments or international agencies' (Beetham, 1995: 60). This point is echoed by Marshall who stated that:

... there remains something vitally important, even irreplaceable, about the notion of human rights. It is better able than any equivalent phrase to give voice to certain essential convictions about the worth of human life, the nature of human relationships, and the limits of state power (Marshall, 2001: 34).

\subsubsection{Redressing the imbalance: New Zealand response}

The UN Committee on Economic, Social and Cultural Rights has stated that it is the 'progressive realisation' of these rights that will ensure their implementation. ${ }^{118}$ Article 2(1) of the ICESCR asserts that each state party must:

... take steps, individually and through international assistance and co-operation, especially economic and technical, to the maximum of its available resources, with a view to achieving progressively the full realisation of the rights recognised in the present Covenant by all appropriate means, including particularly the adoption of legislative measures. ${ }^{119}$

This progressive realisation is in contrast to the immediately enforceable requirements of the ICCPR. There have been many comments on the imbalance between first and second generation rights implementation. For instance in 2003 the HRC noted:

In Western countries, civil and political rights have taken precedence over economic, social and cultural rights. However, it is increasingly accepted that all rights are equally important and cannot be considered in isolation from each other. New Zealand can take some credit for this development, having argued vigorously at the time the United Nations Charter was being drafted at San Francisco in 1945, and later, for economic, social and cultural rights to be given equal weight with civil and political rights (HRC,

117 For a discussion on welfare rights see James (2009).

118 Three ways that states can breach the realisation of these rights are set out by Geoff Budlender. The first is by being inattentive i.e. failing to 'appreciate the nature and extent of the obligation concerned'; the second by incompetence, where although the state realises what is needed, 'the machinery of state is inadequate to the task'; and the third is intransigence, with the state actively choosing not to abide by covenant obligations (Budlender, 2006: 139).

119 Economic, social and cultural rights are also known as 'programmatic or progressive rights' (Conde, 2004: 152). 
Later in 2007 Geiringer and Palmer noted:

Generally speaking, ESC rights have not been subject to the same extensive degree of standard setting that has attended the international regulation of $\mathrm{CP}$ rights and, accordingly, the language in which they are cast is often imprecise ... it is clear that as a general proposition, ESC rights currently receive substantially less judicial protection in New Zealand than CP rights do (Geiringer and Palmer, 2007: 13).

The Re-evaluation of the Human Rights Protections in New Zealand report confirmed this and discussed the role of national plans of action in relation to all rights:

... there has been an imbalance in the promotion of the international level of economic, social and cultural rights and the right to development on the one hand, and of civil and political rights on the other. A NPA places human rights improvement in the context of public policy, so that government, individuals, groups, communities and others can endorse human rights objectives as practical goals, devise programmes to ensure their achievement ... and allocate appropriate resources. ... the NPA should adopt a comprehensive approach to human rights, giving equal attention to all categories of rights (Ministry of Justice, 2000a: 21, 108, 109).

Endorsing the UN view that these rights needed to be 'progressively realised, not just aspired to', the New Zealand NHRI, the HRC, stated in the action plan for human rights for 2005-2010 that many studies:

... provide compelling evidence of the persistent inequalities in people's experience of economic, social and cultural rights [and they] do not generally have the same level of legislative protection as civil and political rights (HRC, 2005a: 31).

The Commonwealth Secretariat report on best practice for NHRIs noted that they have a 'crucial role to play in promoting and ensuring the indivisibility and interdependence of all human rights' (Commonwealth Secretariat, 2001: 33). ${ }^{120}$ The Secretariat asserts that NHRIs should do everything possible to advance these second generation rights 'whether or not its enabling statute or national constitution recognises economic, social and cultural rights as justiciable' (Commonwealth Secretariat, 2001: 33). To ensure this the Secretariat suggested that NHRIs: develop educational programmes for the public sector and the public about economic and social rights; scrutinise laws for consistency with the ICESCR; identify national benchmarks for the realisation of ICESCR obligations and conduct research into this area; monitor compliance with ICCPR rights; and examine complaints infringing these rights (Commonwealth Secretariat, 2001: 52).

120 For a good example of the interdependence of the rights in the ICCPR and ICESCR see Broeks $v$ The Netherlands (UNHRC Communcation No. 172/1984, a case where married women (but not married men) were discriminated against by unemployment legislation. 
The HRC action plan for human rights for 2005-2010 sets out strategies for the provision of economic and social rights. Poverty, housing, health, education and employment are five key areas prioritised in the plan to achieve improvements. The first goal is the reduction of poverty which is seen as undermining 'the realisation of the most basic human rights, in particular health and education' (HRC, 2005a: 31). The Commission is particularly concerned about child poverty. ${ }^{121}$ A three-pronged strategy to improve housing, education and work in tandem is described in the NPA as 'crucial to poverty reduction' (HRC, 2005a: 31). The development of an official poverty measure is also recommended.

Another key issue is housing. Barriers to realising the right to housing are 'affordability and accessibility' and more strategies are needed for those at the lowest end of the housing spectrum - the homeless (HRC, 2005a: 31). Supplying social housing and helping disadvantaged groups (disabled people, Māori and Pacific people, the elderly and refugees) is also recommended. Sub-standard housing is another issue raised in the NPA (HRC, 2005a: 32). The third economic and social right discussed in the NPA, health, is determined by many factors: environmental, socio-economic and access issues. The plan highlighted that 'housing, education and employment are major contributors to people's health status' (HRC, 2005a: 32-33). Māori and Pacific people have the poorest health outcomes in New Zealand on many indicators. The NPA also flagged a whole-of-government approach to issues such as air and water quality, incorporating Māori concepts of health into the mainstream system, and initiating a public discussion about a ‘human rights approach to health' (HRC, 2005a: 34).

The section on education in the plan looked at the area of adult literacy, stating that: 'The 1996 International Adult Literacy Survey (IALS) found that one in five New Zealanders had poor literacy skills' (HRC, 2005a: 34). The Adult Literacy Strategy (operated by the Tertiary Education Commission) is one step towards alleviating this problem, although adult literacy classes at night-school facilities contentiously had their funding cut in 2009.

\footnotetext{
121 This is confirmed by a recent report prepared for the Children's Commissioner and Barnados on addressing child poverty in New Zealand. It found that: 'In 2006/07, 22 percent of children were living in households with incomes below the 60-percent-ofmedian [of the] income poverty line' (Fletcher and Dwyer, 2008: 1).
} 
The final right raised in the plan is employment. Again, Māori and Pacific peoples have poorer employment outcomes than other ethnic groups, for instance, higher unemployment rates. Other groups still face problems too: there is prejudice against older workers, disabled people, those re-entering the workforce after raising families and school leavers entering it. Other ongoing issues in the employment sector include the gender gap in pay, with women still earning far less than men. Also, the vulnerability of young people, low-paid employees in the labour market, and people who work as home care and personal support workers (HRC, 2005: 35). The HRC has recommended that New Zealand ratify four ILO Conventions immediately to alleviate these problems. ${ }^{122}$ Other pressing priorities given in the plan are to address the barriers to employment mentioned above and improve gender pay equity and the pay of vulnerable groups (HRC, 2005a: 35).

It is possible that many of the strategies outlined in the HRC action plan for human rights for 2005-2010 can be effected non-judicially i.e. through policies and programmes. This is in line with the trend of a third policy-based approach to human rights implementation. This next section, however, looks at the implementation problem from another angle and examines the issue of justiciability, and the growing literature on the positive obligations of states to provide for these rights.

\subsubsection{Justiciability and the positive obligations of states}

The courts have been reluctant to become involved in issues around the justiciability of second generation rights because allocation of resources associated with many economic and social policies are seen to be the domain of Parliament and not for them to decide. ${ }^{123}$ Lawson $v$ Housing New Zealand is cited as a key domestic case in this area. The complainant, in the absence of any right to housing in New Zealand, sought judicial review of a government policy to increase the rent of state housing to market

\footnotetext{
122 These conventions are: ILO Convention 87 Freedom of Association and Protection of the Right to Organise; ILO Convention 138 Minimum Age for Admission to Employment; ILO Convention 159 Vocational Rehabilitation and Employment (Disabled Persons); ILO Convention 183 Maternity Protection (HRC, 2005a: 35).

123 A clear definition of 'justiciable' was given by Victor Conde: 'A word describing the character of an issue as legally capable of being resolved by resorting to a legal process. One asks whether an issue is justiciable i.e. whether a court/tribunal has the power to handle/resolve the issue. Certain issues cannot be resolved by courts but must be resolved by executive/administrative procedures. It is a question both of the competence of the court/tribunal and the nature of the issue. In some jurisdictions e.g. political questions are considered to not be justiciable by courts. Such issues are called non-justiciable. They are to be resolved in a non-judicial forum' (Conde, 2004: 143).
} 
levels. She claimed that she was unable to meet the rent and, as a consequence, would be forced to leave her home. This amounted to her being deprived of affordable shelter and was a breach of the right to an adequate standard of living and, therefore, Article 1 of the ICESCR. Williams $\mathrm{J}$ in the High Court held that the matter involved: 'Strong policy considerations and was [therefore] not amenable to judicial review ... the issue of compliance with international treaties was determined by international forums, not by the court' (HRC, 2004a: 2).

The Commonwealth Secretariat NHRI report mentioned above noted that not all governments agree that these rights can easily be translated into legislation. Bob Hepple also stated that: 'economic and social rights are usually cast in the form of soft law or policy goals' (Hepple, 2006: 116). Article 2(1) of the ICESCR emphasises the full realisation of economic and social rights, including particularly the adoption of legislative measures'. The ICESCR committee was concerned at the time of New Zealand's initial ICESCR periodic report that this country's delegation had (in discussions about NZBORA) expressed the view that economic and social rights were not necessarily justiciable. The New Zealand response was that after considerable debate the government had decided not to include social and economic rights in the Bill of Rights Act. The delegation cited Sir Geoffrey Palmer's rationale during the second reading of the Bill in 1993:

\footnotetext{
The Bill does not include social and economic rights. The Bill is focused on fundamental civil and political rights, such as the right to freedom of speech and the right to vote. A Bill of Rights is traditionally concerned with putting restraints on the powers of the state, and is about guarding individual liberty. Social and economic rights are in a different category requiring positive action by the state. That does not mean that those rights are of lesser importance; it means that they need to be protected in a different way (MFAT, 1994: 10).
}

Twelve years later in the Foreign Affairs, Defence and Trade Committee's inquiry into the role of human rights in foreign policy this committee gave a similar view on the protection of rights when it discussed New Zealand's legislative readiness to ratify treaties:

In the field of human rights, it has been unnecessary for New Zealand to engage in massive legislative change in order to give effect to newly assumed international obligations. The reason for this is that New Zealand, with its strong common law tradition together with the separation of powers and independent judiciary, has provided the necessary safeguards for the protection of most civil and political rights. Similarly, the state's commitment to social welfare rights has ensured that no specific legislative action was required to give effect to the rights protected by the International Covenant on Economic, Social and Cultural Rights (NZ House of Representatives, 2005: 56). 
The group of 29 international law experts who met in 2006 to consider the more effective implementation of the ICESCR developed the 'Limburg Principles' (International Commission of Jurists, 2006). No. 8 of these principles stated:

\begin{abstract}
Although the full realisation of the rights recognised in the Covenant is to be attained progressively, the application of some rights can be made justiciable immediately while other rights can become justiciable over time.
\end{abstract}

As can be seen there was a clear intention on the part of this group to maintain the momentum for legal implementation of second generation rights.

When analysing the question of the justiciability of second as opposed to first generation rights much of the discussion focuses on the blurred role of the state and the courts in trying to address the broad problem of the implementation of these rights as set out in this ICESCR. While a trend towards non-judicial policy-based initiatives has been suggested, several viewpoints will now be canvassed which, despite the reluctance of the courts to become involved, each give a prominent role to them in ensuring the effective implementation of second generation rights. ${ }^{124}$ Before doing this it is noted that Geiringer and Palmer's 2007 article on human rights and social policy in New Zealand looks extensively into the government's substantive obligations in relation to economic and social rights, despite the seemingly imprecise nature of the ICESCR wording, and they make several suggestions in this regard. ${ }^{125}$ The aim here is not to replicate that work, but to canvass views from other countries to show the breadth of the debate and to see if ideas from other jurisdictions might be helpful.

The first view has been expressed by the ICESCR committee in General Comment No. 9: The Domestic Application of the Covenant, which outlines concrete measures for states to elevate second generation rights to similar levels as first generation. New Zealand had been referred to this document after it made the comment that these rights were not necessarily justiciable. General Comment No. 9 stated:

\footnotetext{
124 Major work has been done in this area by the Maastricht Centre for Human Rights which held a seminar on the justiciability of economic and social rights in 2005 with participants from many countries. The papers have been published (Coomans, 2006), and this collection looked at the difficult question of how domestic courts can give effect to these rights when countries have ratified the ICESCR. Coomans believed that there is 'greater interest' in protecting these rights, partly because of 'creative case law coming from a number of domestic systems', including South Africa, and that new ways are evolving of enforcing them through 'judicial and quasi-judicial means' (Coomans, 2006: 3).

125 The suggestions were: '(1) An ongoing and reasonable engagement with the scope and effect of relevant rights; (2) No retrogressive measures; (3) An obligation to "respect" the rights; (4) An obligation to provide minimum levels of realisation?; (5) Participation of rights-holders in policy development; (6) Forms of enhanced accountability; (7) Special protection for the disadvantaged'. For the detailed discussion on this see Geiringer and Palmer (2007: 22-29).
} 
... there is no Covenant right which could not, in the great majority of systems, be considered to possess at least some significant justiciable dimensions. It is sometimes suggested that matters involving the allocation of resources should be left to the political authorities rather than the courts. While the respective competences of various branches of government must be respected, it is appropriate to acknowledge that courts are generally already involved in a considerable range of matters which have important resource implications. The adoption of a rigid classification of economic, social and cultural rights which puts them, by definition, beyond the reach of the courts would thus be arbitrary and incompatible with the principle that the two sets of human rights are indivisible and interdependent. It would also drastically curtail the capacity of the courts to protect the rights of the most vulnerable and disadvantaged groups in society (UNCESCR, 1998: Para 10).

The committee noted that courts worldwide had different ways of dealing with the covenant: some had applied its provisions directly or as interpretive standards while others had paid lip service but there was no practical outcome, and still others had refused to give legal effect to it (UNCESCR, 1998: Paras 13-14).

The second view from Sandra Liebenberg claimed that states have a positive duty or obligation to implement economic and social rights in their laws, policies and programmes. She believed that 'human rights impose both negative and positive duties on the state' (Liebenberg, 2006: 109). Traditional negative liberties are the protection of personal security and property, but a state which recognises its positive duties will also uphold socio-economic rights. The gap between what advanced and developing economies can provide in terms of second generation rights is enormous. Because it is extremely difficult to measure the provision of these rights, Liebenberg endorses the move by the committee to develop indicators to assess state compliance in providing socio-economic rights which focus on three factors: 'availability', 'accessibility' and 'quality of services' (Liebenberg, 2006: 109).

The 1996 South African Constitution entrenches some socio-economic rights (Sections 26-27). These include core provisions for adequate food, water, housing, health care and social security. Liebenberg noted the qualifying phrase which follows the list of these provisions: 'The state must take reasonable legislative and other measures within its available resources to achieve the progressive realisation of each of these rights' (Liebenberg, 2006: 111). This is in line with the ICESCR committee phrase above. Also in South Africa the Constitutional Court has developed a 'model of reasonableness review' (Liebenberg, 2006: 111). Liebenberg believed this is a helpful step as it acknowledges the role of the legislature and executive in policy formulation, but allows the courts the role of assessing whether the programmes in existence are 'reasonably capable' of progressively realising socio-economic rights. She was also positive that 
there have been three examples where the Constitutional Court has been able to operate in the socio-economic area. ${ }^{126}$

A similar view is given by Silvia Borelli. She believed that the concept of states having positive obligations has 'substantially expanded the reach of the human rights obligations of states' and 'undoubtedly vastly advanced the scope of protection of human rights' (Borelli, 2006: 102, 103). In relation to economic, social and cultural rights she said that positive obligations take them beyond being:

... merely aspirational, programmatic statements of intent, to be achieved in a fardistant future, but that they impose concrete obligations on the state, albeit to be progressively realised, which are fully binding on state authorities and are justiciable before both domestic courts, and as a last resort, before treaty-monitoring bodies (Borelli, 2006: 103).

A further view from Iain Byrne noted, in a similar vein to Liebenberg, the difficulty of implementing second generation rights. ${ }^{127} \mathrm{He}$ believed that they have broadly: 'tended to be dealt with from a negative civil liberties perspective rather than the consideration of positive state obligations to provide adequate resources' (Byrne, 2005: 3). He offered the notion of 'indirect protection' as a way forward in ensuring the implementation of these rights and suggested two techniques (Byrne, 2005: 15). The first is to further expand the definition of civil rights. This could be arguing that the right to life has been too narrowly interpreted and should be widened to include that states take all measures to ensure, for instance, that infant mortality is reduced or malnutrition is eradicated. The second is to use cross-cutting methods e.g. linking the issue to legalised equality and non-discrimination provisions (Byrne, 2005: 14-15, 20). An example from The Times (19 May 2009) about the right to life of soldiers stretches the reach of this right:

\section{Courts rule British soldiers covered by right to life}

Army chiefs can be sued over decisions taken in the heat of battle after a Court of Appeal ruling that troops must be protected by the Human Rights Act. The judgment by Sir Anthony Clarke, the Master of the Rolls, and two other judges, makes the Ministry of Defence liable to civil prosecutions by families who claim that the treatment of soldiers who have died on operations overseas might have breached their human rights.

\footnotetext{
126 The first (Minister of Health and Others $v$ Treatment Action Campaign with Others 2005) involved direct instructions from this court where the state was ordered to provide Nevirapine, a drug which greatly prevents mother-child HIV transmission. The drug was actually being offered free by the manufacturer at no cost to the government but it had only been allowed at certain experimental sites. The second case concerned the provision of remedies where a group excluded from eligibility criteria for social assistance was read in to the legislation as a remedy. The third instance involved structural interdicts e.g. cases in which the problems are so systemic that a one-off court order would not work and instead the state is asked to adopt a plan of action for remedying the breach and to work with the Constitutional Court to implement it (Liebenberg, 2006: 111).

127 Byrne's connection to New Zealand is his recent contribution of the Foreword to the 2009 New Zealand Law Review's Special Issue on Human Rights in the Pacific (NZLR 2009: v).
} 
The landmark ruling follows a long-running battle between the MoD and Andrew Walker, the assistant deputy coroner of Oxfordshire, who has criticised the ministry for sending troops to war allegedly with defective equipment.

The judgment provoked anger from General Sir Mike Jackson, the former head of the Army. He told The Times: "I cannot imagine that this is what Parliament had in mind when it voted for the Human Rights Act ... It's potentially very dangerous and could damage operational effectiveness because commanding officers will be concerned that they run the risk of being taken to court over decisions they have had to make." Yesterday's judgment concerned the case of Private Jason Smith, 32, of the Territorial Army, who died of heatstroke in Basra six years ago. At the inquest, in 2006, Mr Walker said that his death was caused "by a serious failure to recognise and take appropriate steps to address the difficulty that he had in adjusting to the climate" temperatures of $50^{\circ} \mathrm{C}$. The coroner said that it amounted to a breach of his human rights.

The MoD conceded that Private Smith was within the jurisdiction of European and British human rights laws because he died while in hospital at a British base in Iraq. But MoD lawyers challenged a general-principle ruling by Mr Justice Collins in the High Court in which he said that members of the Armed Forces always remained in the jurisdiction of the UK and were therefore covered by the Human Rights Act wherever they were serving overseas. The MoD argued that soldiers could not be protected by human rights laws if they were fighting "beyond the wire" of a base. Mr Justice Collins dismissed the MoD appeal and yesterday the Master of the Rolls, one of the most senior judges, agreed with his judgment and also threw out the ministry's case. "For the purpose of determining whether there is a sufficient link with the UK to qualify for protection, it seems to us to make no sense to hold that there is a distinction between a person inside and outside premises controlled by the UK," the judges ruled.

Martin Scheinin, based in Turkey, also advocated using non-discrimination provisions as a way of protecting second generation rights through treaties on civil and political rights. He suggested an 'integrated approach' to first and second generation rights where the latter can be helped by using the mechanisms of the former (Scheinin, 2001: 32-34). He noted a hierarchy of protection of second generation rights: they are most protected in those countries with a constitution or bill of rights containing economic and social rights; then in those with some form of 'treaty-specific incorporating statute' where these rights are automatically incorporated into domestic law (Scheinin, 2001: 49). ${ }^{128}$ The example of Korea was given in Chapter 2.1 where, under the ROK Constitution, recognised international law has the same effect as the domestic laws of the Republic. Sandra Liebenberg adds to this list that a third protection mechanism is 'national institutions' involved in monitoring and enforcing these rights (Liebenberg, 2001: 56). This endorses the view given by the Commonwealth Secretariat earlier that NHRIs have a crucial role to play in this respect, and New Zealand does have the HRC. 
Liebenberg noted that domestic courts have been reluctant to enter the territory of second generation rights because it would seem that judges would then be in a position to shape economic and social policy which would be a clear a breach of the doctrine of separation of powers. Her reaction is:

\begin{abstract}
Separation of powers and respect for the institutional competencies of the other branches of government are certainly constraining influences on judicial power. However this does not imply that the judiciary and international human rights supervisory bodies do not have a significant role to play in holding the state accountable for the impact of its actions and omissions on people's welfare (Liebenberg, 2006: 110).
\end{abstract}

Byrne acknowledged second generation rights are not always codified in domestic law, but like Liebenberg believed that the judiciary has a key role (without violating the separation of powers doctrine) in interpreting what is reasonable access to resources:

How far judges should be prepared to go in deciding questions with resource implications - something which does not just affect the right to health but clearly all economic and social rights (esrs) - is a crucial question ... Much will depend on how far courts will be prepared to go in offering creative but legitimate approaches which do not exceed the scope of judicial powers (Byrne, 2005: 4, 14).

The HRC in New Zealand has also noted that:

The developing jurisprudence of the South African Constitutional Court suggests that, in that country at least, the court considers that the doctrine of the separation of powers does not impede its ability to make decisions that require the Government to adopt policies that are consistent with its obligations under the Constitution (HRC, 2004a: $34)$.

However, much also depends on the financial and resource implications of decisions by the judiciary, but the Constitutional Court in South Africa has twice commented that the courts can require the state to meet constitutional obligations about economic and social rights even though there may be budgetary implications. In the first instance in Minister of Health and Others $v$ Treatment Action Campaign with Others 2005, Geoff Budlender noted the court argued that in these types of cases the government would just have to find the resources' (Budlender, 2006: 140). In another case, Rail Commuter Action Group and Others v Transnet Ltd t/a Metrorail and Others, he noted the court warned the government to be careful about raising human and financial resource constraints as a 'bald' reason not to meet its obligation: unless carefully detailed resource implications were given the court would require the state to comply (Budlender, 2006: 140).

This issue about the justiciability of second generation rights is therefore part of a larger discussion about public policy decisions about resources and the blurred role of the judiciary and Parliament. The courts in New Zealand are caught between UN pressures 
to give legal effect to rights set out in international instruments and domestic concerns that they are over-stepping their judicial functions. New Zealand's third ICCPR periodic report had commented that NZBORA had been given the status of ordinary legislation to avoid a significant shift in the constitutional balance of power from Parliament to the judiciary (MFAT, 1995: 39). However, NZBORA itself has come under intense scrutiny in current debates about the role of the judiciary in its interpretation, particularly charges of judicial activism.

Another view on justiciability is found in literature from the USA. Weak Courts, Strong Rights by Mark Tushnet examined the enforcement of social welfare rights by the courts. This looked at the merits or not of trying to include economic rights in new constitutions, such as the South African model discussed above. He pointed out that historically this is seen as a bad idea, given that although they can be included in the constitution they cannot be enforced by the courts. He called this ability to enforce 'judicial capacity' and believed the unease about it underlies:

\section{... a concern about the ability of the courts to coerce the political branches into making substantial changes in background rules, typically by large programs of social provision that require significant alterations in the distribution of wealth by means of taxes (Tushnet, 2008: 227).}

Tushnet distinguished between strong-form and weak-form judicial enforcement, the first when the courts aggressively enforce second generation rights. This would have the effect of forcing legislators to make political decisions about increasing taxation or taking other means to gain revenue to pay for the cost of the rights being realised, thus revisiting the resources issue mentioned above in the South African discussion and earlier in the New Zealand housing case. He believed it is going too far, for instance, to suggest that if people are entitled as a right to minimally decent housing that the judiciary should create 'social welfare programs': as this is surely the role of the legislature (Tushnet, 2008: 232). He also suggested, however, that it was because of the legislature that there might be a lack of adequate housing in the first place:

The fact that the courts have found a constitutional violation means that the legislature's own priorities placed attainment of the social welfare right below other social policies - national defense, building new roads, and the like. So, in enforcing social and economic rights, courts displace legislative judgments about how social policies should be ranked (Tushnet, 2008: 233).

Tushnet further distinguished between rights that are: (a) non-justiciable; (b) weak substantive; and (c) strong substantive (Tushnet, 2008: 238, 242, 245). In relation to the first he cited the Irish Constitutio, which lists social welfare rights but has a 
qualifying paragraph making them non-justiciable. An instance of weak substantive rights involves another South African case: Government of South Africa and Others $v$ Grootboom and Others 2000 (11) BCLR 119 (CC). This involved appalling housing conditions in a shantytown, where a group was moved and then evicted into a worse area. Even though the Constitutional Court asserted it was not its role to determine minimum core standards or decide 'how public revenues should most effectively be spent', they did find the people involved were in desperate need and the government housing programs were not addressing this (Tushnet, 2008: 243). The court required the government to include a 'people in desperate need' provision in their planning for these programs. As Tushnet noted there was not necessarily any 'individualized relief', but in line with the ICESCR statement set out above about progressive realisation, the government was urged to make reasonable progress towards realising the right to minimal standards of housing (Tushnet, 2008: 244). Also in line with the covenant, immediate results are not expected.

Unlike weak substantive rights, strong substantive rights can entail immediate relief. Tushnet cited the first South African case mentioned above - Minister of Health and Others v Treatment Action Campaign with Others 2005 - in which the Constitutional Court enforced the social welfare right to treatment with Nevirapine as an example of these strong rights. In this case, as the drug was free, there were no budgetary implications if a court enforced them. The Constitutional Court therefore directly ordered the state to provide the drug to the women involved and cited decisions in other jurisdictions in these types of cases (e.g. the USA, India, Germany and the UK) in entering a 'mandatory injunction' to the government (Tushnet, 2008: 247). Tushnet therefore argued that perhaps the distinction between non-justiciable, weak and strong rights is simply one of the timing of the judicial remedy: strong rights get immediate remedies; weak rights have theirs deferred; and non-justiciable get none at all (Tushnet, 2008: 250). He then posited two fixed points: one that 'first generation rights must be enforced in the courts'; and the second that 'modern constitutions must contain guarantees of social and economic rights' (Tushnet, 2008: 251). This is in contrast to Sir Geoffrey Palmer's view that NZBORA as part of New Zealand's constitutional framework should not contain these types of rights (MFAT, 1994: 10).

Finally Matthew Palmer's 2008 book on the Treaty has a section on 'Creeping Monism: Amplifying Indirect Enforcement through International Law'. This discussed issues 
similar to those just raised above. While his focus is on indirect ways to implement Treaty rights, his findings are helpful in examining indirect ways of achieving the implementation of second generation rights via the courts. He noted that USA academic Melissa Waters 'identifies a cross-national trend of courts finding indirect ways of giving legal leverage to international obligations that are not formally 'incorporated' into domestic law' (Palmer, 2008: 210). He also noted that Waters has set out:

\begin{abstract}
... five primary means by which courts use interpretive techniques to incorporate international human rights treaties in domestic law. A court can: point to the provisions of an international treaty as additional support for its own interpretation of a statute; interpret an ambiguous statute so as not to violate a treaty obligation; use a treaty as a key source for updating the common law; interpret domestic constitutional provisions so that they conform to international human rights law (Palmer, 2008: 211).
\end{abstract}

Theorists in a number of jurisdictions - New Zealand, the UK, South Africa, Turkey and the USA - are therefore grappling with this problem of legitimately implementing second generation rights through the courts. Martin Scheinin made the point that it is not so much whether rights are justiciable or not, as 'the significant issue is the effective protection of the rights in question', whichever mechanisms you use (Scheinin, 2001: 54). He also referred to the notion of positive state obligations as being 'legislative, budgetary and other', again focusing on the outcome and not the various means by which these rights can be implemented (Scheinin, 2001: 54).

\title{
6.1.3 Potential ideas
}

This chapter has given various overseas examples that show attempts have been made to realise second generation rights through the courts without violating judicial boundaries. As far as can be ascertained, these legal angles have yet to be explored in this country. New Zealand's constitutional framework is quite different, with economic, social and cultural rights having explicitly been excluded from NZBORA. This notion of the positive obligation of states to provide these rights has perhaps been too firmly skewed towards judicial solutions and Table 7 shows how these ideas developed with the courts in mind could be explored from a policy angle in New Zealand. The policy and legal approaches are therefore pragmatically intertwined and complementary. It is possible that (1) Indicators, (2) Breach assessment and (6) Model of reasonableness 
review in this table could be looked at from a policy instead of legal perspective. ${ }^{129}$ The HRC has already suggested that indicators should be developed (HRC, 2004a: 24). This notion of realising some of these ideas from a policy angle means that this could be a move from a court-based to a policy-based approach. It also means the state sector acting differently, and requires a change in public servant behaviour if there is a demand for a different type of state intervention that is skewed away from the legal approach.

\section{Table 7. Possible policy and legislative initiatives to improve implementation of second generation rights}

\begin{tabular}{|l|l|}
\hline POLICY INITIATIVES & LEGISLATIVE INITIATIVES \\
\hline $\begin{array}{l}\text { (1) Indicators } \\
\text { The idea of developing indicators - such as } \\
\text { availability, accessibility and quality of } \\
\text { services - to assess state compliance in } \\
\text { providing socio-economic rights } \\
\text { (Liebenberg) }\end{array}$ & $\begin{array}{l}\text { (4) Widening first generation rights } \\
\text { Further widening the definition of civil rights so that some } \\
\text { economic and social rights can be caught under their } \\
\text { umbrella e.g. right to health linked to right to life case law }\end{array}$ \\
\hline $\begin{array}{l}\text { (2) Breach assessment } \\
\text { Assessing whether New Zealand is } \\
\text { breaching any of these rights because of (a) } \\
\text { inattentiveness, (b) incompetence, or (c) } \\
\text { intransigence (Budlender) }\end{array}$ & $\begin{array}{l}\text { (5) Cross-cutting } \\
\text { Using cross-cutting methods such as linking a second } \\
\text { genation issue to equality and non-discrimination } \\
\text { provisions in law (Byrne, Scheinin) }\end{array}$ \\
\hline $\begin{array}{l}\text { (3) Model of reasonableness review } \\
\text { Developing a 'model of reasonableness } \\
\text { review' to see if rights are in fact being } \\
\text { progressively realised (Liebenberg) }\end{array}$ & $\begin{array}{l}\text { (6) Interpretive incorporation } \\
\text { Using interpretive incorporation techniques e.g. point to the } \\
\text { provisions of an international treaty as additional support } \\
\text { for its own interpretation of a statute; interpret an } \\
\text { ambiguous statute so as not to violate a treaty obligation; } \\
\text { use a treaty as a key source for updating the common law; } \\
\text { interpret domestic constitutional provisions so that they } \\
\text { conform to international human rights law (Waters) }\end{array}$ \\
\hline
\end{tabular}

129 I am indebted to Michael White (Legal and Policy Advisor at the HRC) who raised an alternative view in relation to the model of reasonableness review. While such a review could be carried out from a policy perspective if carefully framed, he raised the issue that for it to have any real teeth there may need to be a legislative requirement for the review (such as currently happens with the NZBORA vet) to ensure it was not inappropriately or incorrectly applied (White, 2009: Personal communication). 


\subsubsection{Resource implications}

Weaving a path between realising international treaty rights and the availability of resources within states has been a theme in this chapter. The courts have been reluctant to become involved in issues around the justiciability of these rights because allocation of resources associated with many economic and social policies are seen to be the legislature's domain. It is also the case, however, that other generations of rights are expensive: first generation rights need a legal system with a judiciary and enforcement agencies; third generation often involve large claims such as Treaty of Waitangi settlements; and fourth generation are now becoming costly to realise as countries try to meet Kyoto Protocol and other environmental-related requirements.

This raises the issue about whether rights can actually regress in a given state, or whether citizens should perhaps not expect that resources will become more available on every front at all times. There has definitely been an overall progression in the realisation of human rights in New Zealand at many levels. However, as seen from this chapter, the resource-dependent nature of their provision means that they are a moveable feast. The provision of human rights, and the primacy that they have in any country or region, is extremely situation-dependent on where they sit amongst other factors (that it can be increased or decreased at any time). There has, therefore, not been a linear progression of human rights even among Western nations since the UDHR was signed in 1948. The whole domestic human rights framework can experience growth, then fragmentation, followed by re-integration, and this research has shown this pattern has occurred in New Zealand.

Each government has to make a trade-off in provision of services, and in times of recession cuts may be made to areas that were previously more generously funded. New Zealanders have already made significant trade-offs, for example exchanging free tertiary education for a student loan system, but this was done so that many more people could attend these institutions. Again, the right to sue was traded for the introduction of the ACC system. Some may argue that cutting adult literacy classes in the current climate is a regression of the right to education; others that it is contestable if the money is being better spent elsewhere (perhaps in an area which helps realise the right to health). It is also possible to imagine degrees of provision - a gold-plated health care system, an average one, or a minimum/skeletal system - and this will depend of course 
on a mixture of government policy and public pressure. ${ }^{130}$

It can be seen therefore that the provision of rights may go up and down, and as with any government policies choices are contestable. Is there a difference therefore between rights and political largesse? Perhaps at the level of providing for the most vulnerable it is possible to definitely use the language of rights. One of the useful points that the human rights field brings to such discussions is the notion of 'non-derogable rights' i.e. those that are not under any circumstances contestable such as the right not to be tortured. Another helpful point comes from New Zealand's own human rights legislation. Section 5 of NZBORA contains the phrase: 'the limits that are demonstrably justified in a free and democratic society'. This is useful when rights seem to be breached, but for the protection of larger public policy reasons. ${ }^{131}$

The HRRT had made a decision in January 2010 about whether an issue was a justified limitation under section 5 of NZBORA. This case involved family members as paid caregivers, and is an example of whether or not the state will provide resources to a certain group. In Atkinson v Ministry of Health (Decision No. 01/2010 (HRRT 33/05)), nine plaintiffs challenged the Ministry of Health's policy of excluding family members of people who are eligible for disability support services for payment for providing their services because of their family relationship. This was said to breach section 19 of NZBORA. The Tribunal's decision was that the plaintiffs were successful at that stage, and the exclusion policy was 'inconsistent with section 19 of NZBORA in that it limits the right to freedom of discrimination, both directly and indirectly, on the grounds of family status and is not, under section 5 of that Act, a justified limitation'. However, following this decision the Crown announced it would appeal and the case went to the High Court in June 2010, and has now been adjourned until $2011 .^{132}$

There can also be resource implications related to gender rights. A key case was the complaint that the New Zealand Students' Association (NZUSA) lodged with the Human Rights Commission in 2003. At the time there was interest on students loans,

\footnotetext{
130 For a useful discussion on the complexity of resource allocation in policy making see Considine (1994: 31-33). 131 Noort's Case (Ministry of Transport v Noort [1992] 3 NZLR 260 (CA)) is such an example. This was a drink-driving test case where the section 5 justification was invoked in order to reduce the road toll. The rights of the individual in this instance were infringed in the interest of public safety.

132 See Ministry of Health v Atkinson CIV-2010-404-287, 30 June 2010. For a full report of the HRRT's January 2010 judgment see Decision No. 01/2010 (HRRT 33/05), which also gives the Ministry of Health's reasons why they felt there was no breach of section 5 or section 19.
} 
and the Association claimed that two factors in particular (the gender pay gap and time spent away from the workforce caring for children) meant that women ended up paying more for their qualifications than men. The claim was eventually withdrawn because of the Labour Government policy change to cease interest on student loans prior to the 2005 election. $^{133}$

Having examined second generation rights this research now turns to third generation rights. An emerging area is the assessment of the human rights implications of the Treaty of Waitangi.

\subsection{Human rights dimensions of the Treaty of Waitangi}

\subsubsection{How is the Treaty a human rights document?}

Some of the 1994-2009 evaluation and planning initiatives raised the issue of clarifying the relationship between the Treaty of Waitangi and human rights. The HRC's Consistency 2000 project final report noted that the Treaty was: 'relevant to the assessment of legislation, policies and practices for consistency with the Human Rights Act' (HRC, 1998: 68). The Commission has called the Treaty a human rights document (HRC, 2009b: 2). The HRC's analysis of the Treaty is developing over time and it has come to the view that that it has three aspects, the middle one related to human rights. First it established the Crown/Rangitira relationship. It also laid out both indigenous rights and universal human rights. Finally it 'sets out the rights and responsibilities' surrounding the three aspects: the Crown has a right to govern, Māori have a right to live in their own way, and there are citizenship and equal rights for all New Zealanders. This is a complete view therefore of what the relationships are, how they connect to the international and domestic human rights frameworks, and who benefits and needs to take ownership in relation to the three aspects.

The Re-evaluation of the Human Rights Protections in New Zealand report authors also asserted the need to clarify the relationship of the Treaty with domestic and international human rights law. They encouraged a better understanding of the human rights dimensions of the Treaty because there was a strong linkage between the Treaty 
and the UDHR. ${ }^{134}$ They also recognised that the Treaty is a 'human rights instrument' and that it:

... encompasses respect for cultural life, non-discrimination, equality and other fundamental principles, all of which resonate with international human rights law. Moreover, both international human rights law and the Treaty anticipate that a reasonable balance may be struck between the rights of individuals and groups. In this sense, therefore, the Treaty of Waitangi is a human rights instrument and it, too, has informed the understanding of human rights which underpins this Report (Ministry of Justice, 2000a: 24).

The HRC established a specific 'Human Rights and the Treaty of Waitangi: Te Mana $\mathrm{i}$ Waitangi' project in 2003. Between 2003 and 2007 the project involved a nation-wide community dialogue programme that had 16,000 participants. It raised the tension between individual rights (a key feature of the Western model) and collective group rights (that reflect a cultural perspective) but noted that all these rights are inter-related (HRC, 2003: 7). ${ }^{135}$ This is in line with an earlier theme of this research that seeks to find a parity and commonality between first (civil and political) and second (economic, social and cultural) generation rights. A further development would be to also find common ground between first, second and third generation (group) rights, and the indigenous protection triangle can be seen as a step towards this. Again, this would be a form of complementarity. Much work is currently being done on clarifying the similarities between the Treaty and the human rights framework. First, in the same way that human rights implications are vetted whenever a new Bill or Regulation passes through Cabinet, Bills also have to be vetted for consistency with the principles of the Treaty (HRC, 2003: 16). Secondly, one view is that it can be considered 'an international treaty between two sovereign nations' and the HRC report above confirmed this stance:

The English text of the Treaty is consistent with the forms of treaties of international law and is concerned with matters such as the cession of sovereignty (or kawanatanga) in exchange for the grant of British citizenship which properly fall within the scope of an international treaty (HRC, 2003: 18).

\footnotetext{
134 The report also suggested the following linkages between Article 2 of the Treaty and domestic and international human rights laws and treaties: 'section 20 (right to culture) of the New Zealand Bill of Rights Act, the international jurisprudence generated by article 27 (right to culture) of the International Covenant on Civil and Political Rights, and article 15 (right to cultural life) of the International Covenant on Economic, Social and Cultural Rights' (Ministry of Justice, 2000a: 38).

135 Currently the HRC has published a Te Mana I Waitangi draft for discussion (HRC, 2010). This will form the basis of a separate chapter on the Treaty and human rights in an updated version of the status report Human Rights in New Zealand Today (HRC, 2004a).
} 
Because of these commonalities the report concluded that Treaty rights and human rights are complementary concepts. Three other similarities are that both the Treaty and human rights 'govern relationships' between citizens and the Crown, are 'part of New Zealand's constitutional framework', and are about evolving rights, although there will inevitably be conflict and tension between the rights of different parties (HRC, 2003: 19). Clarification has therefore happened at a number of levels: that the Treaty is indeed a human rights document; its relationship to domestic and international human rights frameworks is becoming increasingly understood; and that individual and collective rights sit together and not at odds.

The education aspect of the fifth phase of New Zealand's human rights history is evident in Māori language school initiatives and in the wider public education work of the HRC when it collaborated with other agencies to publish the report on building human rights communities in education (Amnesty et al, 2007). This report noted a specifically Treaty-based Māori approach to human rights education (Amnesty et al, 2007: 11), including the development of 'A Draft Charter of the Rights of the Māori Child: Te Mana o te Tamaiti Māori' (Early Childhood Development, 2002). The report also cited the philosophy of the Kohanga Reo movement giving a 'communal lens to human rights' that is based on five principles (Amnesty et al, 2007: 14). ${ }^{136}$ Thus the needs of Māori children are linked through every level of Māori society and with the responsibilities of the state sector and its special relationship to the Treaty. Wider public education is also the focus of two parts of the HRC's work programme: an internal scoping paper on the human rights dimensions of the Treaty (HRC, 2009b); and work linking the Treaty with the language of human rights. ${ }^{137}$

Another HRC project, which is a work-in-progress, is a draft table that links the Treaty with the language of human rights (see Table 8). Given the poor economic and social statistics for Māori generally, making this link echoes the view given by Beetham

\footnotetext{
136 These five principles are: 'Principle 1: It is the right of the Māori child to be raised in the Māori language within the bosom of the whanau; Principle 2: It is the right of the whanau to nurture and care for the mokopuna/children and grandchildren; Principle 3: It is the obligation of the hapu/clan to ensure that the whanau is strengthened to carry out its responsibilities; Principle 4: It is the obligation of the iwi/tribe to advocate, negotiate and resource the hapu and whanau; Principle 5: It is the obligation of the Government under Te Tiriti o Waitangi to fulfil the aspirations of the Māori people for its future generations' (Amnesty et al, 2007: 14).

137 Similar work carried out in this area is the New Zealand Law Commission's (2006) report Converging Currents: Custom and Human Rights in the Pacific. This explored the sometimes difficult interface between Western human rights and indigenous Pacific culture, and suggested ways to 'harmonise' the tensions looking for areas of commonality as a starting point.
} 
earlier. He claimed there is value in keeping up the pressure for human rights in the economic and social area as they sound more authoritative than basic welfare goals and they emphasise the obligations of governments. The table shows that the flip side of rights is responsibilities and that carefully examining the relationship between the Treaty and the Crown can unpack where these lie. One of responsibilities is that the community protects and assists youth and the next section looks at the still very poor statistics for Māori vs non-Māori children and young people.

As well as clarification and education, collaboration is a key feature of the fifth phase and one aspect of this is the penetration of these issues into the state sector and local government. For instance in 2006 the Ministry of Justice, Te Puni Kokiri and the Crown Law Office developed a policy framework giving guidelines and advice to state sector agencies about the Crown-Māori relationship (TPK, 2006). ${ }^{138}$ 
Table 8. The Treaty and human rights

\begin{tabular}{|c|c|c|c|}
\hline & $\begin{array}{l}1 . \\
\text { Kawanatanga } \\
\text { Governance }\end{array}$ & $\begin{array}{l}2 . \\
\text { Rangatiratanga Self- } \\
\text { determination }\end{array}$ & $\begin{array}{l}3 . \\
\text { Rite Tahi Equality } \\
\text { Turanga-awaewae }\end{array}$ \\
\hline \multirow[t]{3}{*}{ Who? } & $\begin{array}{l}\text { Crown/ } \\
\text { Government }\end{array}$ & Rangatira & Citizens \\
\hline & $\begin{array}{l}\text { Rangatira gave and the } \\
\text { Crown gained the } \\
\text { authority to govern }\end{array}$ & $\begin{array}{l}\text { The Crown promised to } \\
\text { protect and Rangatira kept } \\
\text { their authority to protect } \\
\text { and develop their taonga }\end{array}$ & $\begin{array}{l}\text { The Crown gave Māori } \\
\text { and British the } \\
\text { authority to belong } \\
\text { and participate as } \\
\text { equals (citizenship) }\end{array}$ \\
\hline & & $\begin{array}{l}\text { Rangatira gave and the } \\
\text { Crown gained the pre- } \\
\text { emptive right to purchase } \\
\text { land Māori wished to sell }\end{array}$ & \\
\hline Rights & $\begin{array}{l}\text { To make laws } \\
\text { Gather taxes } \\
\text { Set up institutions } \\
\text { Make agreements with } \\
\text { other nations } \\
\text { Represent the state }\end{array}$ & $\begin{array}{l}\text { Tikanga } \\
\text { Develop resources } \\
\text { Rangatiratanga } \\
\text { Whanaungatanga } \\
\text { Whakapapa } \\
\text { Wairuatanga }\end{array}$ & $\begin{array}{l}\text { Equality before the law } \\
\text { Fair process } \\
\text { Free speech, thoughts } \\
\text { and beliefs } \\
\text { Good health and } \\
\text { education } \\
\text { Culture } \\
\text { Vote } \\
\text { Turanga-waewae }\end{array}$ \\
\hline Responsibilities & $\begin{array}{l}\text { Ensure laws are fair } \\
\text { Observe principles of } \\
\text { natural justice } \\
\text { Protect our constitution } \\
\text { Provide services } \\
\text { Protect Rangatira-tanga } \\
\text { and indigenous rights }\end{array}$ & $\begin{array}{l}\text { Manaakitanga } \\
\text { Kaitiakitanga } \\
\text { Whakaruruhau } \\
\text { Utu } \\
\text { Tamarikitanga } \\
\text { Whakaohooho }\end{array}$ & $\begin{array}{l}\text { Obey the law } \\
\text { Participate in } \\
\text { community } \\
\text { Vote } \\
\text { Protect and assist youth } \\
\text { Look after people who } \\
\text { are vulnerable } \\
\text { Respect the Treaty }\end{array}$ \\
\hline
\end{tabular}

Source: HRC draft table (Hamilton, 2009: Personal communication)

\subsubsection{Poor statistics: continuing disparities}

The 2009 UPR report noted that:

Despite recent socio-economic improvements, inequalities still persist for Māori in education, health, employment and income. In 200710.1 per cent of Māori students left school with little or no attainment compared to 3.5 per cent of New Zealand European, which is an improvement on previous years. In the year ended December 2007, just 9 per cent of Māori held a tertiary qualification at bachelor's degree level or above compared with 22 per cent of European. In 2000-02 (the most recent years for which data is available) Māori female life expectancy was 73.2 years, 8.7 years below that of non-Māori females (81.9 years), and Māori male life expectancy was 69.0 years, 8.2 years below that of non-Māori males (77.2 years). Māori are also more likely to be unemployed than European and earn less (UNGA, 2009a: 8).

Previously in 2005 the action plan for human rights for 2005-2010 had also identified 
structural disadvantages, continuing discrimination, and challenges in the way the Treaty would be viewed in the future (HRC, 2005a: 23). The plan also acknowledged that good race relations are dependent on the provision of both first and second generation rights. However, the increasing incorporation of the Treaty and the Declaration into the human rights framework also means they are dependent on providing and raising the status of third generation rights. In 2008 the Ministry of Social Development published a report on wellbeing in children and young people in New Zealand which stressed that:

\footnotetext{
Despite the improvements, health outcomes for Māori generally compare unfavourably against those for the total population: Māori have a higher proportion of low birth weight babies, higher infant mortality, lower immunisation rates, poorer hearing and oral health, higher rates of obesity and cigarette smoking and higher rates of youth suicide (MSD, 2008: 7).
}

The picture for education is similar. While there have been improvements compared to previous figures for Māori, when set against the total population indicators are that Māori still have: less participation in tertiary education and less likelihood of staying at school to 17.5 years of age; a strong chance of leaving without higher school qualifications; more truancy; and lower mean scores for reading, maths and science. One positive is that: "The proportion of Māori school leavers with NCEA Level 2 or above increased from 29 percent to 44 percent between 2003 and 2007, the largest improvement of any ethnic group' (MSD, 2008: 7-8).

The figures for economic security show a similar mix of positive and negative indicators, although the positive aspects will undoubtedly become affected by the current recession. The report noted that: 'The proportion of Māori children whose parents were not in paid work fell from 48 percent to 30 percent between 1991 and 2006' (MSD, 2008: 8). Also most young Māori aged 15-24 are more likely to be in paid work than in the $1990 \mathrm{~s}$, but set against the total population, Māori unemployment figures are still high (MSD, 2008: 8). In terms of physical safety, compared to the whole under-25 population Māori youth are 'at greater risk of dying from assault, unintentional injury and motor vehicle accidents' (MSD, 2008: 8). Youth justice statistics paint a similar scenario: young Māori account for 'almost half of all police apprehensions of 14-16 year olds and over half of all cases proved in the Youth Court involving 14-16 year olds' (MSD, 2008: 8). Good indicators are that between 2001 and 2006 there was a doubling of both the number of young Māori who speak te reo Māori and the number who live in homes with internet access, a lessening of those living in 
homes with parents who smoke, and fewer living in crowded houses generally (MSD, 2008: 8).

The UPR report also noted poor statistics for Māori, but gave strategies for trying to improve these:

\begin{abstract}
The Government recognises that it is essential for New Zealand's future to address inequalities for Māori and is taking immediate action to address the impact of the economic crisis on Māori. In January 2009 the Minister of Māori Affairs convened a Māori Economic Summit and is leading a Māori Affairs Ministerial Taskforce on Economic Development. The Government is also working towards the development and implementation of the Māori Potential Approach across the public sector. Te Puni Kokiri (Ministry of Māori Development) is leading this work in cooperation with other Government departments and community groups. This approach is intended to guide the development and implementation of public policy that is derived from and reflects the strengths and aspirations of Māori. For example, the Government is implementing a specific Māori education strategy, which has been developed to focus Government, school and teacher practice on lifting the achievement of Māori students through evidence based practice (UNGA, 2009a: 8).
\end{abstract}

Included in this section on the human rights dimensions of the Treaty is the following discussion on the UN Declaration on the Rights of Indigenous Peoples. As will be seen below much work has been done to align the two documents and the Declaration is considered to be a vital part of New Zealand's protection of third generation indigenous rights.

\title{
6.3 UN Declaration on the Rights of Indigenous Peoples
}

The 2009 HRC scoping paper noted that the human rights dimensions of the Treaty are connected to both the universal human rights of the UDHR and the UN Declaration on the Rights of Indigenous Peoples, which was formally supported by New Zealand in 2009 (HRC, 2009b: 4). The Declaration, like the Treaty, is also seen as a tool to address the ongoing disparities outlined above. The HRC has developed a table that showed the close alignment between each of the 46 articles of the Declaration and the Treaty (HRC, 2009d). Again, like Table 8, it unpacks the rights and responsibilities which underlie both documents and also used the same tri-fold model of authority: kawanatanga - the authority of the Crown to govern; rangatiratanga - the authority of rangatira to protect and develop their taonga; turangawaewae - the authority of citizens to belong as equals.

Briefly, the events leading up to this support were that in September 2007 the UN General Assembly adopted the Declaration which was the result of a long 
process - the drafting work had begun over 20 years before in 1985. It is considered an aspirational document and not legally binding in any way, relying instead on its moral force. ${ }^{139}$ Minimum standards have been set out for the indigenous peoples of the world. It is hoped these standards will ensure their third generation rights are acknowledged and realised including: freedom from discrimination; self-determination; having distinct political, legal, economic, social and cultural institutions; collective rights; land rights; language rights; spiritual and religious freedom; control of educational and health systems and media; and the protection of traditions, histories and customs. One of the important features about the Declaration is that it is not saying anything new and therefore should not be threatening to states. It is largely built on existing international treaties such as the ICCPR, ICESCR and CERD and draws together many rights and explains how they relate to indigenous peoples. As the Commission's scoping paper noted, the Declaration 'does not create new rights' (HRC, 2009b: 13).

New Zealand under the Labour Government did not sign the Declaration in September 2007. At the time of adoption of the draft in June 2006 and later in October 2006 New Zealand, Australia and the USA made two joint statements about their concerns with the Declaration saying it was 'confusing, unworkable, contradictory and deeply flawed' (MFAT, 2006c: 1). The main points of contention were: (a) self-determination; (b) veto power; (c) land and resources; (d) universality of human rights; and (e) lack of definition of 'indigenous peoples' (MFAT, 2006c: 1-2). ${ }^{140}$ Work continued on a

\footnotetext{
139 Despite its non-binding status it is having a powerful effect in the international community because, as the HRC noted in its scoping paper, the Committee on the Elimination of Racial Discrimination is urging states to use the Declaration as an interpretive tool when preparing CERD reports (HRC, 2009b: 12). The scoping paper also outlines various ways the Declaration can be implemented including: 'direct incorporation into domestic law' [Bolivia has done this]; as an educative tool; by Courts when developing and interpreting law [in New Zealand Ngai Tahu v DG of Conservation, 1995, CA 18/85; B v Director-General of Social Welfare $1997 \mathrm{HC}$; as the basis of action plans for the improvement of indigenous peoples' enjoyment of their rights; as a tool for constitutional reform' (HRC, 2009b: 14).

140 The specific comments on each of these areas were: 'Self-determination. The provisions for articulating self-determination for indigenous peoples in this text inappropriately reproduce common Article 1 of the covenants. Self-determination in the Chair's text therefore could be misrepresented as conferring a unilateral right of self-determination and possible secession upon a specific subset of the national populace, thus threatening the political unity, territorial integrity and the stability of existing UN Member States. Veto power? The text also appears to purport to confer upon a sub-national group, a power of veto over the laws of a democratic legislature. Indigenous peoples in our countries can already fully and freely engage in our democratic decision-making processes. But, our governments cannot accept the notion of creating different classes of citizenship. To give one group in society rights that take precedence over those of others could be discriminatory under the Convention on the Elimination of Racial Discrimination. While the Convention allows states to take special measures, the power to do so is discretionary, and cannot be used to take measures that are unlimited in duration. Land and resources. The provisions on lands and resources in the text before us are also equally unworkable and unacceptable. They ignore the contemporary realities in many countries with indigenous populations, by appearing to require the recognition of indigenous rights to lands now lawfully owned by other citizens, both indigenous and nonindigenous. Such provisions would be both arbitrary and impossible to implement. Universality of human rights. Other important provisions in the Chair's text are potentially discriminatory. It seems to be assumed that the rights of all individuals, which are enshrined in international law, are a secondary consideration in this text. The intent of states participating in the Working Group was
} 
compromise text and by 31 August 2007 the New Zealand Government was satisfied that the text had made some headway on the self-determination issue. However, the overall feeling was that the minor changes made did not answer more serious concerns about the draft wording as they affected some of this country's 'basic constitutional and legal arrangements' (MFAT, 2006b: 1-2).

After the 2008 election the National Government took a 'wait and see' approach. When questioned in the House on 31 March 2009 by the Hon Hone Harawira about when New Zealand would give unqualified support for the Declaration, the Prime Minister John Key stated his government would revise its position once the Australian Government had reviewed their stance and 'see whether its interpretation is applicable in New Zealand' (NZ Parliament, 2009: 1). ${ }^{141}$ A few days later on 3 April 2009 the Australian Government made a statement on the Declaration which marked a turn-around from their previous position, including on the problematic issue of self-determination:

Today, Australia joins the international community to affirm the aspirations of all Indigenous peoples ... For the first time governments worked directly with Indigenous peoples to develop a significant human rights statement. The decades of work culminated in a landmark document. A document that reflects and pays homage to the unique place of Indigenous peoples and their entitlements to all human rights as recognised in international law. ... On 17 September 2007, 143 nations voted in support of the Declaration. Australia was one of the four countries that voted against the Declaration. Today, Australia changes its position. Today, Australia gives our support to the Declaration. ... The Declaration is historic and aspirational. While it is nonbinding and does not affect existing Australian law, it sets important international principles for nations to aspire to. Through the Article on self-determination, the Declaration recognises the entitlement of Indigenous peoples to have control over their destiny and to be treated respectfully. Article 46 makes it clear that the Declaration cannot be used to impair Australia's territorial integrity or political unity (Australian Government, 2009: 1-3). ${ }^{142}$

\footnotetext{
clear that, as has always been the case, human rights are universal and apply in equal measure to all individuals. This means that one group cannot have human rights that are denied to other groups within the same nation-state. Lack of definition of 'indigenous peoples'. We cannot accept the argument some are making, disingenuously, that this declaration will only apply to countries that have significant or obvious indigenous populations. There is no definition of "indigenous peoples" in the text. The lack of definition or scope of application within the Chair's text means that separatist or minority groups, with traditional connections to the territory where they live - in all regions of the globe - could seek to exploit this declaration to claim the right to self-determination, including exclusive control of their territorial resources. And this text would allow them wrongly to claim international endorsement for exercising such rights' (MFAT, 2006c: 1-2).

141 The USA Government has also been revisiting its stance on the Declaration, partly because of CERD Committee pressure (HRC 2009b: 10).

142 Article 26 states: 'Nothing in this Declaration may be interpreted as implying for any state, people, group or person any right to engage in any activity or to perform any act contrary to the Charter of the UN or construed as authorising or encouraging any action which would dismember or impair, totally or in part, the territorial integrity or political unity of sovereign and independent states'.
} 
On 6 April 2009 the Chief Commissioner, Rosslyn Noonan, and the Race Relations Commissioner, Joris de Bres, wrote a joint letter to the Prime Minister John Key. They acknowledged the Australian stance and linked the Declaration with the Treaty:

\begin{abstract}
For New Zealand the Declaration provides a valuable guide in the development of policies and initiatives to give better effect to the Treaty of Waitangi. Affirming the value of the Declaration on the Rights of Indigenous Peoples for New Zealand before Parliament would highlight the government's commitment to improving CrownTangata Whenua relationships in a very powerful way. It would be particularly appropriate to do it at the time of New Zealand's appearance before the Human Rights Council on Thursday 7 May [2009] for its first Universal Periodic Review of its human rights performance (HRC, 2009a: 2).
\end{abstract}

Progress was finally made towards this country's support of the Declaration. The National-led Government announced formal support through Māori Affairs Minister Pita Sharples at the UN on 20 April 2010. The announcement immediately stirred strong debate about the status of the Declaration and how it would affect the relationship of Māori to the Crown. One commentator, High Court Judge Sir Edward Taihakurei Durie, said for instance: 'I would still rank the day that New Zealand gave support to the declaration as the most significant day in advancing Māori rights since February 6, 1840'. ${ }^{143}$

\title{
6.4 Summary
}

There has clearly been an imbalance in the implementation of first and second generation rights. Third and fourth generation rights have at times perhaps also tended to gain more traction, government funding and public sympathy in New Zealand. There are many voices, however, that are urging that this situation be redressed for economic and social rights. The expert international law group that developed the Limburg Principles in 2006, international organisations such as the UN and the Commonwealth Secretariat, and domestic human rights institutions such as the HRC and authors such as Geiringer and Palmer, are aligning to ensure economic and social rights will be more realisable than in the past. The action plan for human rights for 2005-2010 gave concrete examples of strategies to work on the five key areas where these rights are poorly implemented: poverty, housing, health, education and employment. The development of the 2011-2016 version of the Commission's action plan should help to

143 See www.3news.co.nz/NZ-supports-declaration-on-rights-of-indigenous-peoples/tabid/419/articleID/151854/Default.aspx (accessed on 20 April 2010). 
ensure that indicators are continually monitored so at least some progressive realisation can occur. Nearly all of the recommendations and initiatives in the 2005-2010 plan about second generation rights are policy vs legal-focused and can be carried out without legislative change, in line with the trend of a third policy-based level emerging in New Zealand's human rights framework.

As mentioned, third generation rights are gaining more traction. The blending of the three parts of the indigenous rights protection triangle - the Treaty, the Declaration and a human rights approach - is well underway. The Declaration and the human rights approach are backed by the weight of the institutional and legal international human rights framework and should work to reinforce and strengthen the position of the Treaty as a rights-based document from which some progress for Māori could flow.

So far the research has canvassed New Zealand's relationship to the international human rights framework, the build-up of (and problems with) its domestic framework, and two important issues in the current human rights discussion in this country. This wide background now makes it possible to answer in the next chapter the second research question about what effectiveness look likes. 


\section{CHAPTER 7: COMPLEMENTARITY: WHAT DOES EFFECTIVENESS LOOK LIKE?}

Human rights have become part and parcel of New Zealand governance generally, and in the applied business of domestic and international public policy they are here to stay. The assumption should therefore be that successive governments will want to keep improving this country's record. In this chapter it is now possible to answer the second research question: 'How might effectiveness be characterised in relation to robust human rights governance'? The criteria around this notion of robust human rights governance (hereinafter robustness) are also developed.

This chapter looks at the larger picture of how well the state sector is doing as a whole in facilitating a human rights approach at many levels. The attributes of robustness differ from those found in fragile human rights governance (hereinafter fragility). The second research question will be answered in two parts: clarifying robust vs fragile human rights governance; and then assessing New Zealand's status and effectiveness in terms of robust human rights governance.

\subsection{Clarifying robustness v fragility}

One of the hallmarks of robustness is that there is a good understanding of and interaction with the UN framework, particularly the international instruments and obligations that have been ratified. With fragility there may be a rush to sign treaties so a state 'appears' to be a good international citizen when the implications of fully implementing the rights involved are not fully understood. As noted in Section 2.1, Minister of Justice Simon Power had confirmed that New Zealand's stance is only to ratify in a considered manner (Power, 2009). This thesis has looked at both the topdown influence of the UN towards New Zealand, and the bottom-up influence of this country back towards the UN. What this type of research shows is that the long evolution of governance produces in some states a mentality that is much more susceptible to the kinds of standards that emerged after World War II. In New Zealand's case, it was precisely its participation in the formation of the UN that gave it a bedrock human rights focus, and this had already been foreshadowed in everything that had 
come before such as common law standards. This long evolution is not something that is easily transported into a country like Zimbabwe, for instance, which did not help set up the international human rights architecture and which has had a difficult human rights record. ${ }^{144}$

Each country that joins the UN is invited to accept the human rights framework, but there will of course always be states that do not believe in the human rights principles behind it. It is possible to show these states what mechanisms they need to build robustness (such as bills of rights, NHRIs, domestic laws and policies), but their state sector needs to own these for them to have any real meaning. The ideal environment in which human rights are taken seriously is when there is a rights-sympathetic state sector, a political system compatible with the international human rights system, and citizens willing to create a climate that allows rights to be acknowledged. As New Zealand is fortunate to have all three present, rights have been given a central position as a public policy goal (or a set of underpinning principles).

While some states may not be robust in this area, if there is good intention these countries can be on a spectrum towards becoming stronger human rights environments. Even in states with ongoing human rights abuses, it might be that the NGO sector and other civil society organisations are vibrant and full of people who record human rights violations and provide evidence for when there might eventually be mass prosecutions. This is parallel to the situation in South Africa prior to 1994 when apartheid was overthrown. For many decades before the South African constitution came into effect, civil society organisations, international movements of people, multilaterals and the UN system were building a very deep human rights environment amongst sympathetic people. When the apartheid regime was eventually toppled, this experience meant that

\footnotetext{
144 What is striking about the Zimbabwe situation, however, is that the state sector formally has some of the right human rights credentials, i.e. there is a perfectly good constitution, but the reality is vastly different as many of these rights are constantly breached. The most recent Amnesty International report for instance outlines many human rights problems: the aftermath of the March 2008 elections resulted in 'at least 180 deaths, and at least 9,000 people injured from torture, beatings and other violations perpetrated mainly by security forces, war veterans and ZANU-PF supporters'; perpetrators of human rights violations were not brought to justice and given impunity; extrajudicial executions and unlawful killings; enforced disappearances; torture and other illtreatment; restrictions on freedom of expression and on the work of human rights defenders (see Zimbabwe country report at www.amnesty.org). In terms of its constitution, it has the potential to protect many rights (mainly first generation): Chapter III of the Zimbabwe Constitution (1979 with Amendments to 2005) contains: The Declaration of Rights: 11. Preamble; 12. Protection of right to life; 13. Protection of right to personal liberty; 14. Protection from slavery and forced labour; 15. Protection from inhuman treatment; 16. Protection from deprivation of property; 17. Protection from arbitrary search or entry; 18. Provisions to secure protection of law; 19. Protection of freedom of conscience; 20. Protection of freedom of expression; 21. Protection of freedom of assembly and association; 22. Protection of freedom of movement; 23. Protection from discrimination on the grounds of race etc. A copy of the full constitution can be seen www.parlzim.gov.zw/inside.aspx?mpgid=25\&spid=68 (accessed 5 February 2010).
} 
the state itself could quickly mainstream a human rights focus. So in the one country it is possible to have a state sector treating human rights with contempt and domestic and international actors building a robust human rights mentality.

Also when there is fragility instead of robustness the judiciary can be taken over by the ruling party and used as an instrument of civil war, essentially using the law+litigation framework to prosecute opponents. ${ }^{145}$ Looked at from this perspective, New Zealand is not contesting the viability of the human rights system; there is simply haggling over the margins. Also in this country the state has not been the aggressor; in fact with its social welfare system and willingness to monitor itself with non-discrimination legislation it has largely been the protector. The argument in this country is mostly not about whether the citizen can trust the state, but about how much the state should be involved in legislating on issues. ${ }^{146}$ When there is fragility, however, a state can struggle to accept any core human rights standards and can itself be complicit in crimes against its own population such as genocide. It needs to be remembered, however, that the growth of the human rights system in most western liberal democratic countries has been the result of a domestic struggle against oppression (either by the state or other actors) at one time or another, so the condition of fragility is one that states with robust human rights governance have already gone through at some point.

It is also possible that a government could take a minimalist law+litigation approach and do the least required under international law to fulfil its international human rights treaty obligations. This would be a narrow reading, perhaps a legalistic approach. Also, if in any state sector the relationship between law+litigation and policy is poorly understood, there will be a tension instead of an alignment between the two. Some government agencies within a state (even in New Zealand) may by virtue of their portfolio take a legal stance on issues, while others would naturally tend towards a policy view. With complementarity - proactively combining the law+litigation and public policy fields - the result is closer to a gold standard of international best practice. Many countries cannot afford a gold standard human rights system, but it should still be

\footnotetext{
145 Bradford and Scott (2009: 101) also made the link between fragility and corruption: 'Probably most important is the level of corruption which exists, recognising that all fragile states have a record of corruption in their history; it is a factor which coexists with fragility, just as a relative absence of corruption - and strong independent agencies to combat it - coexists with strong states'. 146 The years 1990-1993 (when three pivotal pieces of human rights legislation were enacted - NZBORA, Human Rights Act, Privacy Act) were an important time for contesting the boundaries of the New Zealand state's area of activity in relation to its citizens.
} 
possible to find some economic and effective ways to reach towards that goal. Here the ongoing debate set out in the previous chapter about how to elevate second generation rights is helpful, as the discussion is already underway about novel ways to increase access to these rights given the ever-present resource limitations in many states.

\subsection{New Zealand's status and effectiveness in robust human rights governance}

It is now possible to assess a number of factors to see what New Zealand's status is in terms of robust human rights governance i.e. how effective has it been? To aid this, Table 9 with 20 criteria has been developed relating to each of the six phases of New Zealand's human rights history. Four categories are used: strong, developing, weak and non-existent. The rationale for using these has already been set out in Section 1.5 on developing criteria for effectiveness.

Looking at Table 9 in detail the 'strong' status is largely related to legal and structural factors i.e. Phase One (international law-making); Phases Two to Four (creation of domestic architecture and streamlined institutions and legislation); Phase Five (judiciary/legal system enforcing international obligations and treaties are ratified after careful checking); and Phase Six (rule of law adhered to, domestic remedies for breaches of international rights). This is not surprising for two reasons. The legal aspect to human rights implementation has always been much more developed than any other, including several decades of academic support in this area. Also, the West's focus on civil and political rights has meant that these first generation rights have received more legal protection and this is reflected in New Zealand's points of strength. The point was made earlier, however, that having an effective human rights system in New Zealand is not just about enacting laws. Other non-legal elements work together to form a wider and tighter framework for international human rights to enter this country and be transformed in the domestic context, and as will now be seen it is these non-legal elements which are the weakest. 


\section{Table 9. New Zealand status - effectiveness in robust human rights governance}

\section{FACTOR \\ PHASE ONE \\ Growth of international architecture - UN-NZ interplay}

(1) Involvement in UN structural development and international law-making

\section{PHASE TWO}

Growth of domestic architecture

(2) Evolving domestic architecture - institutions (especially NHRI), legislation, policies and practices

(3) Ongoing incorporation of international obligations into domestic law if relevant and possible

(4) Clear lead government department with overall domestic oversight for international human rights treaty body reporting and implementation

(5) 'Formal' inter-departmental network of officials (or Human Rights Working Group)

\section{PHASES THREE AND FOUR Stock-take and planning initiatives}

(6) Streamlined institutions and legislation, and stock-take and planning initiatives carried out when necessary

\section{PHASE FIVE \\ More effective implementation}

(7) Judiciary/legal system enforcing international obligations

(8) Treaties ratified after careful check for compliance

(9) Exploring proactive approaches instead of always being reactive

(10) Four-fold human rights domestic framework: organisations, legislation, policy, human rights governance level

(11) Increasing parity across first, second, third and fourth generation rights

(12) Early mainstreaming of human rights considerations into policy making

\section{CURRENT}

STATUS

Strong 


\begin{tabular}{|l|l|}
\hline (13) Cultural issues being worked through & Developing \\
\hline (14) Effective public human rights education programme & Developing \\
\hline (15) State sector and NGOs working together on human rights issues & Developing \\
\hline $\begin{array}{l}\text { (16) Internal human rights training in department and cross-agency training of } \\
\text { policy advisors to ensure good understanding of international instruments and } \\
\text { obligations }\end{array}$ & $\begin{array}{l}\text { Weak - } \\
\text { Developing }\end{array}$ \\
\hline $\begin{array}{l}\text { (17) Concluding Observations recognised as important } \\
\text { PHASE SIX } \\
\text { Robust human rights governance }\end{array}$ & $\begin{array}{l}\text { Weak - } \\
\text { Developing }\end{array}$ \\
\hline $\begin{array}{l}\text { (18) Good international citizen and role model - human rights abuses much less } \\
\text { likely }\end{array}$ & Strong \\
\hline $\begin{array}{l}\text { (19) Good governance practices: democracy, rule of law adhered to, judiciary } \\
\text { and officials not corrupt; public participation }\end{array}$ & Strong \\
\hline $\begin{array}{l}\text { (20) Individuals can get redress for civil and political rights through domestic } \\
\text { remedies }\end{array}$ & $\begin{array}{l}\text { Developing - } \\
\text { Strong }\end{array}$ \\
\hline
\end{tabular}

It is clear from Table 9 that the 'developing' status is almost solely related to Phase Five about more effective implementation, and this again is not surprising because New Zealand has only just completed a 15-year period of review i.e. stock-taking and planning initiatives. These looked at problems in implementation which, having only just been identified in the stock-take phase, will take some time to set in place. The 'weak' and 'non-existent' status areas are in Phase Two and Phase Five. In fact, two out of the four Phase Two factors are not at all strong which indicates this is a phase that definitely needs more work. Summarising, Phases One, Three, Four and Six are strong and Phases Two and Five need to be addressed. This research suggests that if a Human Rights Working Group (or similar body) was established (currently the only 'nonexistent' factor), they could monitor the development of progress towards achieving robustness using these (or similar) phase and status factors.

Since developing this table, a table in the Bradford and Scott (2009) report on developing robust economic governance systems was sighted that takes a similar approach entitled 
'Moving Governance Institutions from a Fragile to a Developed State'. ${ }^{147}$ The term 'human rights' does not feature in their extensive lists, again confirming the disjuncture between general international policy making and the field of international human rights. However, their analogous approach (of moving from fragile to developed - in this thesis from fragile to robust) strengthens this research as the core concepts are being used in another field to understand a related issue. They also make the perceptive point that: 'The mirror image of the strengths of EGMs [economic governance mechanisms] are the weakness factors' (Bradford and Scott, 2009: 101). This is true also of the attempt in this thesis to develop the 20 criteria for robustness; these too are the 'mirror image' of the attributes for fragility. For robust economic governance, Bradford and Scott conclude with nine 'design principles' for establishing this in fragile states. ${ }^{148}$ Each of these principles could equally well apply to the development towards robust human rights governance in a fragile state, and there is probably room for some cross-fertilisation between this research and any efforts to better understand state-level improvements in the human rights field.

\subsection{Summary}

The second research question can now be answered about how effective New Zealand has been in relation to robust human rights governance. It is possible to characterise not 'total' effectiveness, but 'a great measure of' effectiveness, having entered the sixth stage of robustness and with work still to do to bring Phase Two and Phase Five issues into a position of strength. Again, as with the first research question, the diagnosis about how to reach the status of robust human rights governance can be given at least in part, but making the necessary changes can only occur if there is a strong commitment from within the state sector to formally move in this direction.

The next chapter now turns to the two case studies that show how easy or difficult it can be to implement rights from the international arena. That is, the complex alignment that needs

147 Table 2.1 in their report looks at three status levels (conflict prone state/fragile state/developed state) and suggests features that would indicate the range 'no governance' to 'good governance' across three areas (politics/economic and social/security) (Bradford and Scott, 2009: 22-23).

148 These principles are: understanding the 'historical and political context' of the fragile state; seeking a 'stable political and security environment'; the need for 'political endorsement'; the necessity of 'political reform' so that robust economic governance can happen; 'long-term commitment' by other (donor) countries who are trying to help; 'donor coordination' among these countries; 'capacity building'; 'oversight, monitoring and evaluation'; crucial involvement of 'civil society' (Bradford and Scott, 2009: 131134). 
to happen starting with a ratified international covenant, its progression possibly into law and/or policies, and its route down to the rights being enjoyed by individuals, can be more or less out of sync. The military justice system example is a positive one, however, showing the specific processes and mechanisms of the human rights system working at best international good practice and allowing effective complementarity between the law+litigation and public policy fields. Once the case studies have been presented in Chapter 8 (which also deepen New Zealand's human rights story), it will then be possible to make concluding comments in Chapter 9. 


\section{CHAPTER 8: CASE PRACTICE: REACTIVE AND PROACTIVE APPROACHES}

This thesis has analysed the complexity of how human rights have entered into the domestic arena over the last several decades - in an unsystematic way and often reactive to overseas trends or pressure from the UN. The two case studies now highlight similar issues: that policy advisors are working in a bill of rights climate and that the domestic transfer of international human rights is now a core part of their work; that the existence of the Optional Protocol route can have an marked effect on domestic lawmaking; and that there are constitutional issues related to these human rights cases (parliamentary vs judicial boundaries in the Baigent instance and the protection of constitutional rights in the military justice system example). The military justice study in particular also affirms the government's proactive commitment to the effective implementation of international human rights. Each case study will be examined in the light of several layers (see Tables 10 and 12). The starting point for each will be the international covenant context in which these issues sit. Domestic legislative/judicial implications are outlined and the impact at the Cabinet/departmental/policy level is analysed. Finally the effect on the individual as rights-holder is then assessed.

Table 10. Baigent - levels of impact

\begin{tabular}{|c|c|c|}
\hline $\begin{array}{l}\text { INTERNATIONAL } \\
\text { COVENANT }\end{array}$ & $\begin{array}{l}\text { International Covenant on Civil } \\
\text { and Political Rights } 1976\end{array}$ & $\begin{array}{l}\text { Contains right to remedies under Article } \\
2(3)\end{array}$ \\
\hline DOMESTIC LEGISLATION & NZ Bill of Rights Act 1990 & Contains no express remedies \\
\hline JUDICIAL & Court of Appeal 1994 & $\begin{array}{l}\text { Court created remedies in Baigent's case } \\
\text { but this raised issues about judicial } \\
\text { boundaries }\end{array}$ \\
\hline $\begin{array}{l}\text { CABINET/ } \\
\text { DEPARMENTAL/ POLICY }\end{array}$ & $\begin{array}{l}\text { Cabinet and NZ Police response } \\
\text { to case } \\
\text { Input sought from other affected } \\
\text { departments }\end{array}$ & Fiscal, policy and rights implications \\
\hline INDIVIDUAL & $\begin{array}{l}\text { Optional Protocol previously } \\
\text { only route }\end{array}$ & $\begin{array}{l}\text { Individual cases now dealt with through } \\
\text { domestic remedies }\end{array}$ \\
\hline
\end{tabular}


Using these examples this chapter seeks to establish that the penetration of human rights into the New Zealand state sector is a multi-levelled process which goes through a different number of stages, depending on the way the issue arises in the beginning. This is also the last chapter which aligns with Phase Five about the effective implementation of international human rights. The key theme that is most clearly illustrated in this chapter is that of clarification: in both case studies a long process of clarifying the effect of international (ICCPR) and domestic (NZBORA) law on the circumstances of the Baigent case and the military justice system review was needed in order to come to a point where anomalies were ironed out.

\subsection{Baigent's case: reactive}

This section on Baigent sets out the background to the case, including that the Court of Appeal's ruling created new public law remedies. A brief discussion about UN concerns over the area of remedies in New Zealand law prior to the case, and implications that the decision had on individuals using the ICCPR Optional Protocol route, follows. Once the background has been established, the impact of the case on the state sector is examined, particularly the response of Cabinet and the NZ Police. Judicial/parliamentary boundaries are then discussed because the case raised this issue. It is also shown how the case was eventually mainstreamed into the state sector, and a final note is made on the effect of Baigent on another jurisdiction, Australia.

\subsubsection{Background}

The ramifications of this decision were complex and layered throughout the state sector. Briefly the case involved a wrongful search as described by Jerome Elkind in his critique of Baigent:

A detective on the New Zealand Police Force, Detective Drummond, received the following information. A cannabis dealer named Tony O'Brien lived at 16 Main Road, Korokoro with his girlfriend and owned a Mitsubishi L300, registration No LW 9466. On investigation the detective found there was no Main Road in Korokoro. The likely address was either 16 Korokoro Road or 16 London Road. He applied to the Registrar of the District Court for a search warrant for 16 London Road. The address was Ms Baigent's address. It had no connection with Mr O'Brien who lived at 16 Korokoro Road. At 7.30 am on 18 October 1991 the warrant was executed by a team of police officers with Detective Drummond in charge. Ms Baigent was not at home. Her son was at home. He told the Police that they had the wrong address, as did a 
neighbour whom one of the team asked shortly after entry. There was a Jaguar in the garage and no sign of a Mitsubishi. During the search the son showed the team his passport as proof of his identity and phoned his sister who claimed to be a barrister. She also told Detective Drummond that he had the wrong address and that the search was unlawful. It is alleged that he replied "We often get it wrong, but while we are here we will have a look around anyway" (Elkind, 1995: 148).

In Baigent the Court of Appeal created a new public law compensatory damages remedy for cases where rights under NZBORA were infringed and no other adequate remedy (e.g. exclusion of evidence) was available. The court relied on Article 2(3) of the ICCPR which ensures effective remedies under the covenant - this is a binding obligation in international law. ${ }^{149}$ The Court of Appeal's focus was also on the lack of civil remedy for a breach of section 21 of NZBORA (unreasonable search and seizure). The court held that effective and appropriate remedies needed to be available for breach of NZBORA, and that the courts were seen as having a positive duty to provide public law remedies including issuing a stay of proceedings, reducing an offender's sentence, excluding tainted evidence and monetary compensation. These came to be known as 'Baigent remedies' or 'Baigent damages'.

The UN Human Rights Committee had expressed over time a range of concerns about the ICCPR and NZBORA relationship. For instance in the third periodic ICCPR report feedback in 1995, they felt that covenant obligations had not been fully incorporated into domestic law and given an overriding status in the legal system. Some rights guaranteed under the covenant were seen to not to be reflected in the new Act, inconsistent legislation had not been repealed, and NZBORA had no status higher than ordinary legislation. They were especially concerned about 'the absence of express provision for remedies for all those whose rights under the Covenant or Bill of Rights have been violated' (MFAT, 1995: 69). ${ }^{150}$

\footnotetext{
149 The full text of Article 2(3) reads: 'Each state party to the present covenant undertakes: (a) To ensure that any person whose rights and freedoms as herein recognised are violated shall have an effective remedy, notwithstanding that the violation has been committed by persons acting in an official capacity; (b) To ensure that any person claiming such a remedy shall have his right thereto determined by competent judicial, administrative or legislative authorities, or by any other competent authority provided for by the legal system of the state, and to develop the possibilities of judicial remedy; (c) To ensure that the competent authorities shall enforce such remedies when granted'.

150 Butler and Butler (2005: 1118) note in this regard that: 'A number of commentators have noted the statements of the HRC on the coverage of BORA and on its status vis-à-vis other enactments and called for the amendment of BORA so as to better reflect New Zealand's obligations under the ICCPR. Other commentators, however, have criticised the HRC's Concluding Observations on the basis that they call for a level of domestic implementation greater than that actually required by the terms of the ICCPR and that they fail to acknowledge the ability of a state party to give effect to the ICCPR rights through a mix of statute and practice'. This is in keeping with the findings of this research that policy-oriented approaches are being explored in this country as an alternative to legislative options, and the general view of this thesis that the UN committees for the major covenants have favoured a judicial vs non-judicial approach to the implementation of covenant rights.
} 
The New Zealand response to the List of Issues of the UN Human Rights Committee about the status of NZBORA was that after five years of debate about the subject it was decided that 'New Zealand was not ready for an entrenched Bill of Rights' (MFAT, 1995: 39). As already noted in Section 2.1, public opinion was wary of entrenchment because of the possible redistribution of power from elected representatives to an appointed judiciary. There were also other reasons, because as noted the position of the Treaty of Waitangi would have to be very carefully worked through. As a result NZBORA had been passed as an ordinary statute and did not have the status of supreme law. It was also hoped that Cabinet vetting of all new Bills and Regulations would help reduce inconsistencies in future legislation (MFAT, 1995: 39). In terms of lack of remedies, New Zealand was able to report that although NZBORA did not contain express remedies the Court of Appeal had in 1994 held in a decision (un-named case although it was Baigent) that there was a remedy under the Bill of Rights for breaches of NZBORA. The committee was told that in the ruling 'the Court placed reliance on the availability of remedies under the International Covenant' (MFAT, 1995: 39). In this Baigent Court of Appeal case Justice Casey noted the problem of leaving New Zealand citizens with no redress through the domestic courts:

\begin{abstract}
By its accession to the First Optional Protocol to the Covenant on 26 August 1989, New Zealand accepted individual access by its citizens to the United Nations Human Rights Committee for violation of rights under the Covenant, where they have been unable to obtain a domestic remedy. The Act reflects Covenant rights, and it would be a strange thing if Parliament, which passed it one year later, must be taken as contemplating that New Zealand citizens could go to the United Nations Committee in New York for appropriate redress, but could not obtain it from our Courts (Simpson v Attorney General [1994] 3 NZLR 667 (CA) 691, 73).
\end{abstract}

Justice Hardie Boys had noted that:

Citizens of New Zealand ought not to have to resort to international tribunals to obtain adequate remedy for infringement of Covenant rights this country has affirmed by Statute. I consider that the courts are obligated to provide these remedies in domestic law (Simpson v Attorney General [1994] 3 NZLR 667 (CA) 700, 83).

The route between covenant-statute-individual was unclear and the Court of Appeal addressed this by providing domestic redress. However, the effects of the decision were considerable and the next setting for the Baigent journey moved from the courts to the state sector. 


\subsubsection{Impact on state sector: Cabinet and NZ Police response}

In a memorandum for the Cabinet Strategy Committee dated 24 May 1995 the Rt Hon Doug Graham stated that: 'The new public law action for breach of the Bill of Rights Act is identified as the most far-reaching aspect of the Baigent decision' (Office of the Minister of Justice, 1995a: 2). ${ }^{151}$ Immediately after the Court of Appeal ruling a year earlier there had been much discussion at Cabinet/departmental level about reversing the decision by legislation. The NZ Police in particular were in favour of this (Kerr, 1994: 1-2). Potential costs as a result of the decision were considered to be a significant factor in favour of overriding the decision, and the estimates of those costs were huge. The 24 May 1995 memorandum had identified that up until 30 April 1995 the NZ Police had claims totalling $\$ 8.5 \mathrm{~m}$ relating to NZBORA liability and that the Crown Law Office had advised that as they were being 'filed at the rate of about two per week and an average of around $\$ 1 \mathrm{~m}$ per month, the contingent liability would be $\$ 12 \mathrm{~m}$ per year' (Office of the Minister of Justice, 1995a: 9).

Apart from serious fiscal implications, other issues had earlier been drawn to Cabinet's attention by DB Kerr, Chief Legal Advisor to the NZ Police. In a letter dated 25 November 1994 he had raised concerns with the Solicitor-General about the decision's wider impact on policing:

I forsee the creation of a style of defensive policing, defensive Judges and Courts dispensing justice and a defensive style of prison management designed to minimise claims against the Crown. ... the Police will be forced to adopt defensive policies to decrease [the contingent] liability to save money for operational policing. Primarily I see offenders being summonsed rather than arrested; searches without warrant will become a thing of the past and the number of search warrants issued will decrease markedly either because the Courts will refuse to issue them or the Police will be reluctant to request them other than when very good evidence exists to justify them. Judges will then be reluctant to remand prisoners in custody or send them to prison on conviction if there is any possibility of the jury verdict being overturned on appeal. ... Penal institutions will have to treat prisoners with kid gloves to avoid aggravated damages in the event of the conviction being later overturned. None of these outcomes will do anything positive for Law and Order in New Zealand and in due course there will be a major public outcry. I enclose a copy of my pessimistic forecast to our Policy and Planning Section who are scoping an environment scan in preparation for the round

\footnotetext{
151 Memorandum for Cabinet Strategy Committee. Baigent's Case: Options for Government dated 24 May 1995 stated three options: '(i) Legislate to overrule the decisions in the Baigent and AUWRC cases to provide that no public law action lies for breach of the Bill of Rights Act; (ii) Let the decisions stand without modifications; or (iii) Let the decisions stand with modifications, the form of which would be identified in a review of Crown liability generally which could be done in two stages: (A) The first stage would focus on making amendments directed at limiting the scope of the Baigent public law action by providing defences and clarifying areas of procedural uncertainty; (B) The second stage would involve more general legislative changes relating to Crown liability (whether under the Bill of Rights Act or otherwise) and would lead to a new Crown Proceedings Act)' (Office for Minister of Justice 1995a: 11).
} 
1995/96. The financial implications for the Government are enormous, the implications for the Police and law and order in general are also enormous. Unless the Privy Council overturns the Court of Appeal [sic] the Government is going to have to look at seriously re-writing the Crown Proceedings Act to prevent these outcomes. I believe that while the right of appeal exists the Government must exercise it before considering major changes to the law to avoid severe public criticism (Kerr, 1994: 1-2).

An Addendum document attached to this letter, 'Implications of Baigent Decision', had given a long list of rights which the NZ Police believed at the time would 'be vulnerable to civil action in the future under the Baigent decision':

- Right not to be deprived of life [e.g. fatal road accidents involving the police]

- Right not be subject to torture or cruel treatment [e.g. allegation of assault by a police officer]

- Right to refuse to undergo medical treatment [e.g. the police calling in a doctor to an injured person]

- Freedom of expression [e.g. language offences by police officers]

- Freedom of peaceful assembly [e.g. Springbok tour scenarios]

- Freedom of association [e.g. not allowing suspects to associate with others]

- Freedom of movement [e.g. time spent in custody without a conviction]

- Freedom from discrimination [e.g. bypassing the Human Rights Act to make direct claims for discriminatory behaviour]

- Rights of minorities [e.g. gangs or cults might claim police harassment]

- Unreasonable search and seizure [e.g. Baigent now gives no protection to the police despite executing a judicial search warrant]

- Right not to be arbitrarily arrested or detained [e.g. possibly easier chance of acquittal since Baigent]

- Breach of rights of person charged [e.g. may lead to more civil action as a result of Baigent]

- Minimum standard of criminal procedure e.g. undue trial delays could lead to damages for breach of right] (Kerr, 1994: Addendum 1-3).

On 6 April 1995 DB Kerr again wrote to the Secretary for Justice with more concerns about the effect on policing:

The Police are exposed to enormous potential liability under the Baigent and AUWRC decisions because every arrest, refusal to grant bail, search with or without warrant, vehicle stop and crime scene the Police must use their statutory powers which exposes them to allegations of abuse of those powers and potential civil claim for damages. Successive governments have provided the Police with the statutory tools to maintain law and order but those tools now provide the basis for a counter attack on the Police (Kerr, 1995: 2).

During the course of this research information was also received from the NZ Police about their reaction to NZBORA from as early as $1990 .{ }^{152}$ The NZ Police Gazette,

152 This information (McCullough, 2009: Personal communication) included extracts from the NZ Police Gazette (1990), an internal police document New Law; legal information provided to officers on NZBORA; a copy of law notes relating to NZBORA material published in the NZ Police publications The Bulletin and Ten-One; and the relevant sections of the Manual of Best Practice on the NZ Bill of Rights (available on the NZ Police intranet) referred to in Inspector Spackman's letter above. 
published in 1990 (the same year as the Act), noted in relation to unreasonable search and seizure that:

... should a power of search be exercised other than in accordance with the statute giving the authority, or not in terms of the consent that was given, a court will probably hold it unlawful. This is essentially what the law is now, but it is likely to be of greater significance under this legislation (NZ Police, 1990: 249).

The following year (1991) the NZ Police Bulletin commented on NZBORA:

The Bill of Rights Act 1990 has far-reaching implications for the police - especially for those on the streets, regularly enforcing police responsibilities. The Act came into force in September last year, but many police are still unsure of its provisions and how they relate to every-day policing. According to Neville Trendle, Chief Legal Adviser, Police National Headquarters, the Act was clearly one of the most important pieces of legislation for the police yet. It was of critical importance to law enforcement. "It has the potential to have major implications for policing. Police dealing with arrests, searches, bailing and other day to day activities need to understand the Act's provisions, and comply with them. The most critical consequence of non-compliance with the Bill of Rights will be in the courts, where evidence could be rejected because of a breach", said Neville (NZ Police, 1991: 14).

In 1992 the New Law (Issue 6) publication issued a four-page guide containing Bill of Rights checklists. This also warned officers that the impact of NZBORA was significant:

PLEASE NOTE: The world has changed. The Bill of Rights is here to stay. Do you risk losing your case and thereby wasting valuable time and resources by trying to 'short circuit' the Bill of Rights. The Courts have made it quite clear that they will not tolerate such tactics. It may well be that the days of the confessional statement are numbered and that prosecution cases will stand or fall on eyewitness or circumstantial evidence (NZ Police, 1992a: 1).

In the next instalment of New Law (Issue 7) in the same year more information was given in this statement:

BILL OF RIGHTS - Legislative change - The [four-page] guide [Issue 6] may have given the impression that the Police had 'rolled over' on the Bill of Rights. That is not true. The Commissioner will be making submissions to Government for amendments to blunt the adverse effects that some of the more literal views of the courts are having on the process of maintaining law and order. The guide's prime objective was to leave staff in no doubt as to what the law is now (NZ Police, 1992b: 1).

The NZ Police Index also cited several cases for the years 1991 to 1995 in relation to section 21 Bill of Rights searches without a warrant or unlawful search instances: $R v$ Watt (1991), $R$ v Laugalis (1993), Hufflett $v R$ (1993), Tuki $v$ Police (1993) and $R \vee R$ (1994) (NZ Police 1995: 9). Despite the huge reaction to the case - from Cabinet level downwards - Baigent (Simpson v Attorney General) is not used as an example in this Index or in the current NZ Police best practice manual on NZBORA (NZ Police, 2009) which is regularly updated. 
In a further memorandum to the Cabinet Strategy Committee dated 16 August 1995 the Rt Hon Doug Graham noted in similar vein to the NZ Police response: 'If there were liability for all negligent conduct resulting in a breach that could result in "overdeterrence" thus impacting on the ability to govern effectively' (Office of the Minister of Justice, 1995c: 8). The memorandum for the committee had also reached a position on how to proceed in the interim. Cabinet had directed: a first stage review of the issue of Crown liability by the NZ Law Commission; the examination of public liability approaches in other jurisdictions; and the monitoring of Baigent fiscal liabilities and the need to amend current legislation (Office of the Minister of Justice, 1995c: 2). By this time (four months since the 30 April 1995 estimate) the memorandum noted that the Crown Law Office had estimated it had ' 20 sets of proceedings based wholly or in part on the Baigent action, most of which are against the Police' and 'The amount claimed now totals approximately $\$ 24.95 \mathrm{~m}$ ' (Office of the Minister of Justice, 1995c: 1).

The potential fiscal and other effects of the Baigent decision on a number of government departments - through various Acts and the powers given to staff under them - meant wide consultation was carried out to identify at-risk areas. Some of these areas identified in May 1995 were:

- The Justice Department felt the most significant impact of NZBORA would be 'departmental compliance costs (e.g. providing more court facilities and upgrading prison conditions) rather than individual awards of damages'.

- Department of Labour concerns centred on risks of Baigent damages against immigration officers and OSH officials.

- ACC identified a possible weakening of their 'ability to enforce medical examinations and treatment under sections 64 and 73 of the ARCI Act'. They expressed concern that 'The Corporation's ability to carry out its statutory duties in a responsible and accountable manner could be severely affected'.

- Customs noted that their officers had powers under the Customs Act 1966 to search and detain people's property which could be affected.

- The Department of Social Welfare was concerned about liability for the actions of social workers and other personnel working with child abuse cases or with 
children under CYPS protection.

- The Ministry of Education identified some employees working in the areas of investigation and inspection who might be at risk.

- MAF noted that many frontline staff - biosecurity personnel, meat inspectors and fisheries officers - could be exposed to NZBORA liability.

- The Department of Internal Affairs also had staff working in several areas who might also become vulnerable: gaming inspectors, civil defence staff and Films, Videos and Publications Act inspectors.

- The Inland Revenue Department identified relevant personnel e.g. those with the power to inspect documentation.

- Department of Conservation staff identified some warranted officers under the Wildlife Act 1953, the Marine Mammals Protection Act 1978, the Wild Animal Control Act 1979 and the Trade in Endangered Species Act 1989.

- The Ministry of Health identified the Mental Health Act 1969 and the Mental Health (Compulsory Assessment and Treatment) Act 1992 as potential sources of liability, particularly claims of 'false imprisonment and non-consensual treatment of persons committed to hospitals' (Office of the Minister of Justice, 1995b: Schedule 1-6).

Despite pressure from the NZ Police to overturn the legislation it had even earlier been decided to take a modified approach. In a letter dated 27 April 1995 the Secretary for Justice wrote to the Commissioner for Police: 'We have therefore modified the options, proposing now that there be a partial review of Crown liability with a view to devising amendments that would see the public law remedy retained but constrained' (Hay, 1995: 1). The 16 August 1995 memorandum for the Cabinet Strategy Committee noted that the Solicitor-General had been instructed by it on 14 December 1994 'that the appeals to the Privy Council should be discontinued' (Office of the Minister of Justice, 1995b: 1). Fairly soon after the Court of Appeal decision the matter had therefore been resolved: the legislation was not overturned but the new remedy was confined within boundaries acceptable to the state sector. 
The NZ Police response in 1994-1995 was that the decision was going to be hugely problematic at three levels: fiscal, policy and rights. However, these fears were unfounded. When contacted in October 2008 the current Acting Chief Legal Advisor did not share his predecessor's concerns about the effect on policing:

\begin{abstract}
The Baigent case did not change the style of policing used by Police or lead to any amendments to operational instructions. Decisions that police officers make on a daily basis are grounded upon common sense considerations. With no ability to legislate common sense, inevitably a decision reached will be held to be wrong and Police will be held accountable. ... Police training and the Manual of Best Practice on the Bill of Rights Legislation is periodically reviewed and updated to incorporate judicial decisions where appropriate and necessary (Spackman, 2008: 1).
\end{abstract}

From a fiscal perspective he was unable to advise the cost of Baigent damages to the NZ Police in the intervening years. However, he had noted that the Quantifiable Contingent Liability was about $\$ 1.2 \mathrm{~m}$ in 2007 and $\$ 548,000$ to 30 June 2008, much less than the \$24.95m quoted for 1995 (Spackman, 2008: 1).

Advice from the NZ Law Commission was very much in favour of ensuring remedies rather than swaying in the direction of the panic that was being felt throughout the state sector about whether the decision was workable from an operational or fiscal perspective. In their detailed report on the subject published three years after the case the Commission asked 'whether the Baigent remedy should be altered or abolished by legislation' (NZ Law Commission, 1997: 26). In their view this was not necessary for three reasons: 'the need to provide an effective remedy for breaches of rights under the Bill of Rights Act; the development of common law remedies to protect rights and interests similar to those in the Act is likely to be slow and sporadic; international law supports linking remedies to rights' (NZ Law Commission, 1997: 26). The NZ Law Commission also noted in their report that: 'Appropriate remedies [including monetary remedy] ... are all essential means of emphasising that the state is subject to the law' (NZ Law Commission, 1997: 26). This was a tick for remedies in general, and a further tick for monetary remedies. Again, this was less about what government departments might find uncomfortable in terms of these types of decisions, and more about the New Zealand state providing redress for breaches of civil and political rights under domestic law and international obligations.

\title{
8.1.3 Judicial boundaries
}

One positive effect of the UN-New Zealand dialogue about NZBORA and the express 
remedies discussion was that it resulted in a higher profile for covenant obligations in judicial decision-making, a theme which has echoes in other parts of this research. New Zealand's fourth periodic ICCPR report made the general comment that the covenant was now more prominent before the courts and in government decision-making than ever before (MFAT, 2002: 14-15). ${ }^{153}$ In 1996 the NZ Law Commission had published a guide to increase the awareness of international law, including treaty obligations (NZ Law Commission, 1996).

On the other hand the area of possible judicial activism in relation to Baigent has been viewed as controversial and much of this discussion has centred on the intent of Parliament. In the 16 August 1995 memorandum, the Rt Hon Doug Graham had concerns about the operation of the new public law action: 'If left to the courts [it] can be developed in a piecemeal way only' (Office of the Minister of Justice, 1995c: 2). He further claimed that: 'Baigent is a case of constitutional significance as it relates to the nature and extent of the respective law-making roles of Parliament and the Judiciary' ... and 'in Baigent the Court of Appeal has gone further than Parliament [had] intended' (Office of the Minister of Justice, 1995c: 4, 6). Matthew Palmer agrees about the lack of intention:

In 1994 in Baigent's Case, the Court of Appeal 'interpreted' the New Zealand Bill of Rights Act 1990 impliedly to contain the remedy of public law damages. This was achieved in the face of Parliament explicitly having already considered, and rejected, the inclusion of such a provision. Constitutional "dialogue" ensued where the executive was tempted but, with advice from the Law Commission, ultimately declined to introduce over-ruling legislation in Parliament (Palmer, 2008: 241).

The Rt Hon Doug Graham addresses similar issues in a section on 'Roles of Parliament and Courts' in the 24 May 1995 memorandum for the Cabinet Strategy Committee:

It was not envisaged when the Bill of Rights Act was passed that the Courts would take
it upon themselves to fashion a new type of action, as has been done in Baigent, when
Parliament had specifically decided not to do so. In the Baigent and AUWRC cases a
theme in all the judgments was that Parliament could not have intended to pay lip-
service to the rights and freedoms affirmed [in] the Bill of Rights Act and that, although
there is no remedies provision in the Act itself, the Courts could supply those remedies.
The Judges regarded this as an application of the common law principle that where

153 However, Butler and Butler (2005: 1117) stated that: 'Overall, our impression is that even within the legal community, awareness of the ICCPR is limited. BORA has raised the ICCPR's profile a little. Judgments citing articles of the ICCPR and/or views adopted by the Human Rights Committee ("HRC") under the Optional Protocol to the ICCPR have increased over the years in New Zealand ... Nonetheless, reference to the ICCPR and the HRC's views is still, relatively speaking, limited'. Four years later in February 2009 the UN Human Rights Committee of the ICCPR noted its satisfaction that in the determination of cases the New Zealand courts take account of the covenant and of its general comments (UNGA, 2009c: 12). This was in response to New Zealand's fifth periodic report to the ICCPR stating that the covenant was central in New Zealand law-making and citing various Supreme Court cases where it had been a key factor (MFAT, 2007: 8-9). 
there is a right there should be a remedy ... In contrast to the remedies that Parliament envisaged would be available (fettered in the case of tort by the scope of the tort and by statutory immunities), the public law remedy is at this stage untrammeled by any such constraints (Office of Minister of Justice, 1995a: 5).

He then stated that NZBORA affirms New Zealand's commitment to the ICCPR and that Article 2(3) about effective remedies was a binding obligation in international law, but said: 'the Government considered that it already met that obligation under the general law as it stood prior to the two cases' (Office of the Minister of Justice, 1995a: 5). Butler and Butler also noted about this judicial/parliamentary boundary issue that:

\begin{abstract}
... a number of commentators argued (and have continued to argue) that it was illegitimate for Judges to create new remedies to give effect to NZBORA rights. In our view the Court of Appeal's decisions on remedies are perfectly defensible and we support the path along which the Court struck out. At the same time, however, we acknowledge that a differently constituted Court of Appeal, approaching BORA against the background of its legislative history, might have adopted a much more conservative approach to remedies, utilising only those remedies generally available at common law and exercising them by reference to criteria established by the common law, with no reweighing of interests to reflect the new statutory status of the guaranteed rights. In this limited sense, the Court of Appeal's BORA jurisprudence can be legitimately labelled as "bold". But, at the same time, it cannot be regarded as being particularly creative. Truly new remedies, such as sentence reductions, have not yet found favour with the Court (Butler and Butler, 2005: 1111-1112).
\end{abstract}

While there has been much disagreement on the intent of Parliament and the legitimacy of the remedies, the Rt Hon Doug Graham did believe that the Baigent decision importantly cast light on a number of areas that needed resolving. He stated that the Crown Proceedings Act 1950 was 'badly in need of replacement' and the decision had highlighted 'gaps in coverage and apparent inconsistencies ... [and] ... raises issues about the extent of a bad faith exception to immunities' (Office of the Minister of Justice, 1995a: 7). The Secretary for Justice, writing to the Commissioner of Police on 27 April 1995, noted that Crown Law was advising more discussion about 'the reasons for statutory immunities and constitutional issues (judicial v parliamentary lawmaking)' (Hay, 1995: 1). Because Baigent damages were created in public and not private law (tort), the NZ Police echoed the Rt Hon Doug Graham's concerns about the lack of constraints. They also believed that the Court of Appeal had 'circumvented' Crown and police immunities and protections in the Crown Proceedings Act 1950, the Police Act 1958 (now repealed) and the Crimes Act 1961.

The area of a lack of express remedies in NZBORA was crying out for a court case: a set of facts was needed and in Baigent the set of facts was perfect. Normally the violation to the right would be dealt with by the remedy of exclusion. Here there was no evidence to exclude, so the straightforward question was is this just too bad or is there a 
need to provide damages? Also, it was not a simple case of every time someone's rights are breached the courts are now going to have to pay damages. What the Baigent decision said was that if there is no other avenue, the courts might have to give damages, but much of the time the remedies will emerge from other circumstances. The question is not have you got a right to damages, but have you got an effective protection of your right? The case therefore raised a number of issues about judicial interference, but it also highlighted areas of law which needed tightening. As the ruling was not overturned, the next phase in the Baigent story became the gradual accommodation of the decision into the everyday functioning of the state sector.

\subsubsection{Eventual mainstreaming}

In Baigent the domestic courts effectively said it is inappropriate to have New Zealand citizens complaining to the UN Human Rights Committee - the Optional Protocol route. They felt the need to give NZBORA some teeth and this was their way of doing it i.e. by providing damages. However, the public service then reacted that this was going to be very difficult to implement, but officials were eventually able to accommodate this change. This case highlights the broader question of how these rights come into New Zealand via the interaction between the international arena and the domestic sphere.

Table 11. Mainstreaming process - Baigent

\begin{tabular}{|l|l|}
\hline \multicolumn{2}{|l|}{ UNEXPECTED NEW ISSUE INTO STATE SECTOR } \\
Instigator (lead role): Courts & Alienation - Panic - Rejection \\
\hline Stage 1: & Acceptance \\
\hline Stage 2: & Modification \\
\hline Stage 3: & Implementation - Assimilation \\
\hline Stage 4: & $\begin{array}{l}\text { Mainstreamed into public policy } \\
\text { (no more law change) }\end{array}$ \\
\hline Stage 5: &
\end{tabular}


Baigent is also an excellent illustration of the five-stage mainstreaming process that this research suggests occurs when a new issue arrives unexpectedly into the state sector (see Table 11). Initially a change is seen as completely foreign; then there is a period of acceptance and modification until it becomes workable. Finally there is an acclimatisation phase where the issue becomes mainstreamed. Once the change is implemented it becomes part of public policy and the resistance turns to acceptance. This is the same way that mores are changed. Issues surrounding homosexual law reform are now mainstream compared to 1986 when people believed this would be a catastrophic change. Sixteen years on from Baigent it is now inconceivable that the right to damages would be challenged from within the public service, and there has also not been the cost blow-out predicted as the courts have proved reluctant to award large amounts in damages. ${ }^{154}$

\subsubsection{Australian reaction}

The above discussion looks at Baigent's impact domestically, but the case has also been cited in Australia. There are two legislative bills of rights in Australia at the state level. The Australian Capital Territory (ACT) was the first Australian state to provide a bill of rights, the Human Rights Act 2004, which gives the state a 'central role' in human rights protection within its jurisdiction (Evans, 2004: 3). Victoria was the second state to provide a bill of rights in the form of the Charter of Human Rights and Responsibilities Act 2006. Under the Charter all government departments and other public agencies must observe certain rights when developing laws and policies. ${ }^{155}$ Baigent was cited in the state of Victoria before their charter was adopted. For instance

\footnotetext{
154 Noort's Case (Ministry of Transport v Noort [1992] 3 NZLR 260 (CA)) is a similar example to Baigent where the Police said it would not prove workable to provide access to a lawyer in roadside drink driving test situations. The courts ruled that it simply came down to handing the person a cell phone, so in reality it added a slight complication and is now routine. This is an instance where it was possible to introduce a new policy and get it flowing through the system. Unlike Baigent, Noort's Case is not primarily an international covenant case but a Bill of Rights case (only indirectly implementing the ICCPR). However, it is similar to Baigent from a public policy perspective. The same reaction occurred: we can't do this. However, the ruling relied on the 'free and democratic society' exception of section 5 of NZBORA where it was possible to say this was a legitimate restriction, justified by law, but an acceptable one because of the greater good of reducing road deaths. The ruling did intrude into a right, but in protection of a larger one for public policy reasons. Note that the five-stage process of Table 11 would also apply to Noort's Case.

155 For a copy of the charter see www.humanrightscommission.vic.gov.au/about\%20us/default.asp (accessed on 14 February 2010).
} 
looked at the question of damages and Baigent is discussed:

Quite a few submissions argued that a larger range of remedies, including damages, should be available. This is the case in the United Kingdom and by judicial implication also in New Zealand, but not yet in the ACT. The New Zealand Bill of Rights Act 1990 does not mention damages, but the Court of Appeal implied this remedy in a case called Baigent's Case. This decision means that damages are now possible for breaches of the Bill of Rights Act in New Zealand. However, awards under this principle have been rare. ${ }^{156}$ In the United Kingdom people can seek 'just and appropriate remedies'. The right to compensation for human rights breaches is only available if no other remedy is appropriate. This approach was very attractive to many stakeholders, including the Law Institute of Victoria (LIV). The LIV supports the inclusion of an effective remedy under the Human Rights Charter for the infringement of an individual's human rights by any department or agency of government and strongly recommends the adoption of the method of enforcement currently contained in the UK Human Rights Act 1998 (Submission 128). Some people thought that the threat of damages would help to ensure compliance (Victoria Human Rights Committee, 2005: 126).

On the other hand, in the ACT Baigent was cited after their new Act was passed. A 2009 case concerns the availability of compensation under the ACT Human Rights Act for unlawful detention, which is a parallel case to Baigent. The judge concluded:

... that s 18(7) HRA conferred a statutory right to compensation, his Honour left aside the question of whether a general remedy power could be read into the HRA as in Baigents Case. In Baigents Case the NZ Court of Appeal found that even though the NZBORA did not contain an express enforcement provision, effective remedies could nonetheless be available by necessary implication for a breach of rights [Morro, $N \&$ Ahadizad v Australian Capital Territory [2009] ACTSC 118].

Even though general remedies were not made available, in this case damages amounting to $\$ 190,000$ were awarded to the plaintiffs. The issue of remedies is also raised by Carolyn Evans in her commentary on the ACT Human Rights Act 2004 and she used Baigent to illustrate the dangers of lack of clarity in this area. She raised the effect of their new Act on administrative law and is concerned that it does not contain more explicit detail about remedies:

In particular, the deletion of provisions dealing with compensation and the way in which such compensation should be determined will not necessarily mean that no compensation is available for executive breaches of rights. In New Zealand a scheme for compensation as a remedy has been judicially developed despite the (probably intentional) failure to include such an entitlement in the Act [Simpson v AttorneyGeneral]. While the development of a right to compensation under the Act is not terribly likely, the New Zealand precedent shows that it cannot be excluded. If the ACT government wanted to be sure a right to compensation was not available, then it should

156 This is a similar trend to the European situation. Black-Branch noted in his July 2009 talk at the Victoria University of Wellington Law School that the European Court of Human Rights, for instance, has not been known to award large damages. If they do find a breach the remedy of changing the offending legislation or practice is considered enough of a remedy in itself (BlackBranch, 2009). 
have done so expressly rather than leaving the judiciary without guidance on this issue ... an Act that asserts legislative supremacy in the area of rights protection should not have left these issues to the judges (Evans, 2004: 9, 12).

\subsubsection{Summary}

The case is important for several reasons. It is a very good illustration of the clarity by which human rights travel through various levels: covenant-statute-judicialCabinet/departmental/policy-individual. At the covenant level, it is a striking instance of the New Zealand courts taking note of the ICCPR origin of rights protected in a domestic human rights statute (NZBORA). It was also a test case for NZBORA to align more fully with the ICCPR, in light of the affirmation of the covenant being part of the long title to the Act. Not only was Baigent seen to open the Crown to enormous fiscal liability (particularly the NZ Police), from a policy perspective it was feared that it would affect the very way that policing and related operations were carried out. The implications for the judiciary were two-fold. On a helpful note it raised the awareness of international covenant obligations in judicial decision-making. However, more contentiously, parliamentary/judicial boundaries were seen by some to have been crossed. It was also a case that severely stressed the state sector. A positive effect for individual citizens has been direct redress through domestic law instead of via the UN Human Rights Committee under the Optional Protocol to the ICCPR. The review of the military justice system that follows was an altogether more positive experience of mainstreaming human rights issues through the New Zealand state sector.

\subsection{Military justice system: proactive}

\subsubsection{Background}

The issue of the human rights of soldiers in the UK has already been raised, with the 2009 case about whether troops are protected by the UK Human Rights Act 1998 when they are on active service outside their country (see Section 6.1.2). New Zealand has been exploring similar issues for some years. The lack of alignment of New Zealand's military justice system with international human rights law was reviewed between 1996 
and 2007, both internally by the $\mathrm{NZDF}^{157}$ and through two Victoria University $\mathrm{PhD}$ theses. Alex Conte's (1996) research was on the impact of human rights on military discipline in New Zealand. Gordon Hook's (2002) subject was the constitutional status of military tribunals and a critical analysis of New Zealand's military justice system. These two reviews found problems in critical areas taken for granted by civilians such as arrest and search procedures, fair trial rights, the right to consult and instruct a lawyer, and impartiality.

The military justice system is administered by a number of tribunals with the power to impose penalties for offences under the Armed Forces Discipline Act (AFDA) 1971. ${ }^{158}$ The Armed Forces Discipline Amendment Act 1971 (No.2) 2007 was a direct result of an NZDF review carried out between 2002 and 2007. The system is uniquely based on an 'inquisitorial' rather than adversarial system and has two tiers: a 'summary system' gives commanders a way of dealing in a quick and efficient manner with less serious matters; and if an offence is serious enough service personnel may be subject to a court martial (Conte, 1996: 6-7). As NZDF reviewer Christopher Griggs noted, the 1,000 summary disposals carried out each year is a much larger number than the approximate 10 courts-martial, with the former having punishments below the threshold of what are regarded as 'true penal consequences' (Griggs, 2006: 292).

This military justice system case is another very good illustration of the route travelled by human rights at a number of levels: covenant-statute-judicialCabinet/departmental/policy-individual (see Table 12). The Conte and Hook theses will be discussed first as they raised relevant issues before and during the NZDF review. This review will then be looked at, followed by a section on the response of politicians on both sides of the House to the system overhaul and new proposed legislation. Finally, how the changes were eventually mainstreamed into the state sector will be examined.

\footnotetext{
157 The internal Military Justice Review consisted of 30 Options Papers and was authored by Commander Christopher Griggs (2003) and reviewed by Colonel Kevin Riordan, both from the Directorate of Legal Services, NZDF, Wellington, NZ.

158 Before the Armed Forces Discipline Act 1971 there had been other legislation including a Navy Act, New Zealand Army Act and Royal New Zealand Air Force Act, each with its own rules and traditions (Hansard 2007a: 5).
} 
Table 12. Military justice system - levels of impact

\begin{tabular}{|c|c|c|}
\hline $\begin{array}{l}\text { INTERNATIONAL } \\
\text { COVENANT }\end{array}$ & $\begin{array}{l}\text { International Covenant on } \\
\text { Civil and Political Rights } \\
1976\end{array}$ & Asserts basic pre-trial and trial rights \\
\hline \multirow[t]{3}{*}{$\begin{array}{l}\text { DOMESTIC } \\
\text { LEGISLATION }\end{array}$} & $\begin{array}{l}\text { Armed Forces Discipline Act } \\
1971 \\
\text { Courts-Martial Appeal Act } \\
1953 \\
\text { Defence Act } 1990\end{array}$ & $\begin{array}{l}\text { Old legislation and policies inconsistent } \\
\text { with ICCPR and domestic human rights } \\
\text { legislation }\end{array}$ \\
\hline & $\begin{array}{l}\text { NZBORA } 1990 \\
\text { Human Rights Act } 1993 \\
\text { Privacy Act } 1993\end{array}$ & Growing human rights legislation \\
\hline & $\begin{array}{l}\text { Armed Forces Discipline } \\
\text { Amendment Act (No.2) } 2007\end{array}$ & New military law developed \\
\hline JUDICIAL & $\begin{array}{l}\text { Military justice tribunals } \\
\text { (AFDA } 1971 \text { system): } \\
\text { Summary disposals } \\
\text { Courts-martial } \\
\text { Summary trial system } \\
\text { Permanent Court Martial of } \\
\text { NZ }\end{array}$ & $\begin{array}{l}\text { System reviewed before cases tested in } \\
\text { civilian courts } \\
\text { New military court system took effect } 1 \\
\text { July } 2009\end{array}$ \\
\hline \multirow{2}{*}{$\begin{array}{l}\text { CABINET/ } \\
\text { DEPARTMENTAL/ } \\
\text { POLICY }\end{array}$} & $\begin{array}{l}\text { Cabinet agreed to revised } \\
\text { military law and policies }\end{array}$ & Cabinet papers \\
\hline & NZ Defence Force & $\begin{array}{l}\text { Collaborative effort }- \text { departments } \\
\text { consulted by NZDF (Treasury, Ministry of } \\
\text { Defence, Ministry of Justice, CLO, } \\
\text { Parliamentary Counsel Office, MFAT) } \\
\text { plus NZ Law Society and international } \\
\text { military law experts }{ }^{159}\end{array}$ \\
\hline INDIVIDUAL & $\begin{array}{l}\text { Individual service personnel } \\
\text { could not assert rights in } \\
\text { military setting }\end{array}$ & $\begin{array}{l}\text { Legislation now in alignment with ICCPR } \\
\text { and domestic human rights legislation - } \\
\text { averted need for litigation or for case to } \\
\text { UN Human Rights Committee under } \\
\text { Optional Protocol to ICCPR }\end{array}$ \\
\hline
\end{tabular}

159 For more information on this consultation see Hansard (2007a: 4) and NZDF (2009b: 1). 


\subsubsection{Conte and Hook: constitutional unfairness}

These two researchers analysed the implications of NZBORA and the ICCPR for the military justice system. Other countries had endeavoured to make significant changes to their military justice systems in the light of domestic and international human rights obligations, and Conte and Hook were examining this area for New Zealand. The notion of being 'jurisprudentially xenophohic' is mentioned by Hook who said that: 'Learning the lessons of our allies and taking a proactive approach will result in value-added benefits to a critical corner of justice in New Zealand' (Hook, 2002: xxv). In particular, the researchers examined the lack of independence, impartiality and principles of natural justice in military law compared to civil law and raised questions about the resulting breach of basic constitutional freedoms and rights. Conte noted the traditionally conservative viewpoint that soldiers, as servants of the Queen, do not have human rights. He believed that not only are soldiers bound by the AFDA 1971, but they also have individual rights protections under ever-increasing human rights legislation such as the ICCPR, NZBORA the Human Rights Act and the Privacy Act. He claimed that examining the system in the light of these instruments exposed many 'actual and potential' rights infringements (Conte, 1996: 1).

Under the AFDA 1971 and related Acts and Regulations military personnel have different constraints to civilians and are subject to both civilian and military law. Conte asserts that given the overriding purpose of the military justice system is to maintain the defence force personnel 'for its ultimate objective: combat', the necessary obligations and restraints will of course impinge on individual rights and freedoms (Conte, 1996: 25). He quoted a USA Supreme Court Case - Parker v Levy (1974) 417 US 733, 758 in which the judge observed that:

\footnotetext{
... the fundamental necessity for obedience and the consequent necessity for imposition of discipline may render permissible within the military that which would be constitutionally impermissible outside it (Conte, 1996: 103).
}

It was the extent to which these obligations and restraints impinge on individual rights and freedoms that became the focus of his research, and that of Hook and the NZDF reviewers.

Conte and Hook both examine pre-trial issues as well as aspects of the military trial system itself. Conte used section 5 of NZBORA 1990 as the starting point to check whether a military justice system provision or practice is inconsistent with 
the Act (Conte, 1996: 45). ${ }^{160}$ This section 5 places the onus on the NZDF to show that a particular limitation on the rights or freedoms of service personnel 'can be demonstrably justified in a free and democratic society' (the same test applied to Noort's Case just mentioned in the Baigent case study), and that the breach 'must impair the right or freedom as little as possible' (Conte, 1996: 46, 48). Hook's view is that in the last half of the $20^{\text {th }}$ century there has been a 'paradigm shift' in 'operational military thinking from combat to peacekeeping' (Hook, 2002: 3). ${ }^{161}$ Added to this, the military justice system is dealing with 'highly educated, and intensely trained $21^{\text {st }}$ century forces' as well as offences which were unheard of when the system was developed centuries ago (Hook, 2002: 5). Two international instruments which he believed have shone an intense focus on the system have been the ICCPR and the Optional Protocol to that treaty:

The fundamental rights articulated in the former touch criminal justice procedures at the core, while the latter grants the right of personal complaint to the United Nations Human Rights Committee. Neither of these instruments exempt military law or the system of military tribunals by which discipline is imposed on members of armed forces. Moreover, unlike other nations, New Zealand did not express a reservation in regards to its military law and military tribunals when ratifying these instruments (Hook, 2002: 6).

Looking at the system's consistency with NZBORA, Hook noted that the Act only contains one exemption in relation to military justice under section $24(\mathrm{e})$ - the right to a jury trial. ${ }^{162}$ Overall he believed that:

... the military justice system has failed to keep pace with the development of ordinary law yet has remained in existence as a separate code. But neither the ICCPR nor the

\footnotetext{
160 This section reads: 'Section 5. Justified Limitations - Subject to section 4 of this Bill of Rights, the rights and freedoms contained in this Bill of Rights may be subject only to such reasonable limits prescribed by law as can be demonstrably justified in a free and democratic society'.

161 This view was echoed five years later by the Hon Dr Richard Worth in the first reading of the Armed Forces Law Reform Bill in 2007: 'The comment has been made about the number of lawyers in the military. That is a truly striking change. To some extent I am not supportive of that change, but it is the reality that this Government has significantly moved our focus of military activity not from war fighting but to peacemaking. In that peacemaking context the provision of legal advice becomes quite critical. In a war fighting setting those issues do not bear time for reflection' (Hansard, 2007a: 6). In the same reading of the Bill the Hon John Hayes (National MP) states ' $\ldots$ the Defence Force's legal directorate now has 28 officers, compared with four just a few years ago' (Hansard, 2007a: 12-13). The Hon Ron Mark (Labour MP) also commented during the reading that: 'Internationally, most of our friends and allies are involved in peacekeeping and peacemaking operations, and that is a far more complex environment to be working in. The international consequences of a private soldier getting it wrong are considerably greater than they ever were in the First World War, the Crimean War, the Boer War, or the Second World War. These amendments take note and give cognisance to those realities' (Hansard, 2007a: 7). New Zealand policy advisors now need to be aware they are operating in an international as well as domestic legal environment; soldiers operating overseas in a changed role (with local armed services, police and citizens) instead of in combat situations against other troops brings a whole new international legal component to their work.

162 Section 24(e) states that persons charged: 'Shall have the right, except in the case of an offence under military law tried before a military tribunal, to the benefit of a trial by jury when the penalty for the offence is or includes imprisonment for more than three months'.
} 
BoRA are "ordinary law" and if any threat is posed to the current military justice system it is now posed by the Bill of Rights Act 1990 .... It is time to align the military justice system with the constitutional standards in the BoRA and to establish a new paradigm where the need for discipline is subordinate to the requirements of justice (Hook, 2002: 771-772).

He asserted (in 2002) that not making the necessary changes would leave the system vulnerable to litigation on similar human rights grounds which had been successful in overseas jurisdictions (Hook, 2002: 18). At a practical level there are significant benefits in the NZDF identifying these inconsistencies before the issues are raised in the courts as the experience of other countries shows. Griggs noted that even though the British military justice system had been substantially reformed in 1996, it continued 'to be the subject of successful challenges in the European Court until very recently. This process has demanded the devotion of significant resources by the British Ministry of Defence' (Griggs, 2006: 290). Also a case tried in the Supreme Court of Canada $-R v$ Genereux (1992) 70 CCC (3d) 1 - on the grounds that a general court-martial was not an independent and impartial tribunal as required by the Canadian Charter (similar to section 25(a) of NZBORA) was costly for the Canadian Forces. They 'were compelled to expend considerable resources in an effort to substantially reform Canada's military justice system within a tight timeframe' (Griggs, 2003: 2). Griggs himself asserted that 'the Government is now vulnerable to litigation in the superior courts challenging the validity of convictions and sentences imposed by military tribunals on the ground of non-compliance with NZBORA' (Griggs, 2003: 2). It was therefore critical that the changes were made before the situations experienced by other jurisdictions happened here.

Hook had therefore identified broad constitutional issues around lack of alignment between the ICCPR, NZBORA and the New Zealand military justice system. He and Griggs were both warning about the potential litigious element if the system was not updated. Conte in his research had also identified several specific areas with the most potential to be out of alignment with human rights instruments including: arrest, search and seizure; the right to a fair and public hearing by an independent and impartial court; and the right to consult and instruct a lawyer during summary disposals (Conte, 1996: 54). These areas will be examined in turn. 


\subsubsection{Arrest, search and seizure}

Conte asserts that under military law there are possible occasions where orders to service personnel constitute a type of detention or de facto arrest that do not comply with the strict arrest criteria set out in NZBORA. He examined deprivation of liberty of service personnel when they are detained or under arrest, using Froggatt $v R$ [1992] 9 CRNZ 181 as an illustration. Lance Corporal Froggatt received a home visit by the Royal NZ Military Police, and without being informed of section 23 of NZBORA rights was told he was under suspicion for burglary and drug charges and was requested to go with them to the MP section. At the same time, as a serviceperson he was lawfully obliged under section 38 of the AFDA 1971 to obey orders (Conte, 1996: 76-77). Conte noted that the court in this instance - the Courts-Martial Appeal Court (CMAC) - felt it would be 'absurd' if a serviceperson was under detention whenever they were ordered to go somewhere. However, he believed that the discipline and obedience factors in military law led to a relationship between superiors and their subordinates which means more coercion is often exerted than in civil life, and that boundaries can be crossed if strict adherence to detention and arrest guidelines are not carried out (Conte, 1996: 80).

To illustrate this point Conte used Police v Grootjans [1975] 3 NZLR S87 where a naval rating was involved in an onshore hotel brawl. The next day in front of two civil police officers he was ordered by the Master at Arms of the ship to 'tell the truth' - he confessed and was charged with assault. A District Court judge did not find any compulsion but the High Court ruled in Grootjans' favour in an appeal against conviction because pressure from the Master of Arms was 'the exercise of a form of compulsion' (Conte, 1996: 83-84). Conte noted, however, that:

\footnotetext{
As evident in Froggatt, and Isaacs, service members are seldom arrested pursuant to the provisions contained in the AFDA [1971]. More often than not, they are ordered or requested to attend questioning since, from a Commander's point of view, it is much easier to exercise the power of command than to invoke the specific provisions of sections 88-92 (Conte, 1996: 87-88).
}

He believed this constituted not a formal or 'de facto' arrest, but a 'command arrest', and concluded 'the end result is the same: any statements obtained while a person is in a state of arbitrary detention will be prima facie excluded' (Conte, 1996: 88-89). In his view: 'concepts of arrest and detention are just as applicable to the military context as they are to the civil one, with a few potential exceptions' (Conte, 1996: 107). Other difficulties that Conte identified for the NZDF's NZBORA compliance were: there was 
a lack of manuals or service documents across the three services about how to administer section 23 rights; and there was inadequate guidance for NZDF Commanders who had powers of subjecting personnel to different types of arrest (Conte, 1996: 89-90). The main consequences Conte sees for a breach of NZBORA for the NZDF were inadmissibility of evidence, invalidation of processes, and (since Baigent) a concern about liability for damages under the Act. In his view it is possible for 'human rights and military discipline' to 'co-exist', but 'the New Zealand Defence Force has a responsibility to ensure that its system of military discipline marches in time with the requirements of human rights law' (Conte, 1996: i).

\subsubsection{Judge and jury}

Hook (2002: 485) affirms Conte's statements about the difference between the civil and military justice systems, but has even more concerns about military officers playing 'multiple roles (investigative, prosecutorial and adjudicative)':

... the essential functions that make up a justice system, namely the investigative prosecutorial and judicial functions - all separated within the civil justice system - are unified within the armed forces command ... In short, they are the police, the prosecutor, the judge and the jury, all in one. The civil system moved from this paradigm of justice centuries ago as a failure of fundamental justice (Hook, 2002: 12, $731)^{163}$

In particular Hook felt the summary disposal process was flawed because it failed to meet the basic requirements of natural justice and believed 'servicepersons accused of military offences and convicted by military tribunals have been dealt with by a system which is systematically unfair' (Hook, 2002: 484-485, 726). He also said that:

\footnotetext{
... giving effect to New Zealand's legal obligations under the ICCPR ... and except for the right to a civil jury only, Parliament did not exempt the armed forces justice system from any of the general procedural and substantive rights of the BoRA ... military tribunals must offer the guarantees of independence and impartiality. Compliance with these principles is particularly important in the armed forces, given the very close proximity of the executive (i.e. command chain) to the tribunals responsible for determining allegations of offending. ... Under a system designed to ensure compliance, subordinates may be charged with disobeying lawful orders by the very officers who issued those orders and have those charges determined by the same superiors (Hook, 2002: 728, 729).
}

163 Hook (2002: 13) noted progress in this area in Canada and the UK where extensive reviews of the military justice system with domestic and international human rights legislation had been carried out: 'Investigative powers have been separated from prosecutorial powers; Prosecutorial powers have been separated from judicial powers; Judicial functions have been vested in separate judicial officers; Convening officers have been abolished and "jury" selection replaced with independent authorities'. 
Reasons Hook identified for military commanders not to examine and change the system in the light of these international and domestic human rights instruments included: that summary disposals were, positively, a 'relatively easy' way to deal with justice issues away from civilian or military appeal courts because a speedy disciplinary resolution is often needed. However, more negatively, he saw that hand-picked courtmartial juries of 'senior officers wielding extensive prosecutorial powers without appropriate legislative safeguards to ensure against improper executive influence' may influence trial outcomes before they even start (Hook, 2002: 10). Hook had therefore flagged a huge area of constitutional and procedural unfairness that would be unacceptable in criminal law courts. ${ }^{164}$

\subsubsection{Fair trial rights and instructing a lawyer}

On the right to a fair trial, section 25 of NZBORA sets out the right to a fair and public hearing by an independent and impartial court. Article 14(1) of ICCPR also stated that everyone shall be entitled to a fair and public hearing by a competent, independent and impartial tribunal established by law. However, Conte found that this entitlement is different in military law from civil law in two ways. Section 24(e) of NZBORA demarcates the extent to which the Act applies for service personnel: they have a right to a fair trial 'except in the case of an offence under military law tried before a military tribunal' (Conte, 1996: 35, 48). Section 74 of the AFDA 1971 also allowed the trial of a civil offence (such as offences under the Crimes Act 1961 or Misuse of Drugs Act 1975 ) within the military justice system (Conte, 1996: 139, 183). Conte also researched the related question of consulting and instructing a lawyer in the military system. He

\footnotetext{
164 The three readings of the Bill gave some MPs who had been in the services time to reflect on their own experiences in this area. The Hon Ron Mark (NZ First) told the House: 'I joined the army in 1971 and was subject to the Armed Forces Discipline Act [1971] at that stage. ... Some time later, I had the opportunity to cross swords with an officer commanding, which resulted in me being fronted up as a junior officer - second in command of a unit - on a charge. It occurred to me then that there was no way in heck I was going to take the punishment of a commanding officer, so I opted for a court martial. I did so because I knew straight away that it was by means of a court martial that one could get a fair hearing, and that natural justice would be more likely to be played out and as a result - just for the curiosity of members - they promptly changed their minds and ordered a court of inquiry, which gave me the opportunity to cross-examine my accuser. All charges were dismissed. ... What is pleasing about this bill is that the laws of natural justice and the Human Rights Act are written into this with a far higher degree of compliance than has ever been the case before. ... I could talk about some of the things I observed in the way in which military justice was meted out in my 20 years in the military. Some of it I find still sticks in my throat to this very day. ... I hope that some of the things I witnessed in my time as a junior officer will never ever be able to be played out again, because this bill will clearly take care of what I consider to be anomalies that are well past their use-by date'. ... About military hearings he said: 'I watched three New Zealand soldiers get rammed through hearings at 1.30 in the morning in a tent in the field, without being given the opportunity to seek legal counsel or to get legal advice as to what the consequences of a guilty plea would be. ... those soldiers were put through the disciplinary process in a manner which could only be described as showing undue and unfair haste, which seriously jeopardised and compromised the ability to prove their innocence, or to at least mitigate their case' (Hansard 2007a: 7, 8; Hansard, 2007b: 14).
} 
believed this was a 'sub-right' to the right to consult and instruct a lawyer set out in section 23(1)(b) of NZBORA under which persons arrested or detained: "shall have the right to consult and instruct a lawyer without delay and to be informed of that right' (Conte, 1996: 100). These rights do not exist in the same way as civil law because it is often difficult to arrange this when the serviceperson is on active service in a remote location. There could also be grey areas about when an issue was a matter of discipline to be dealt with at the time and when a serviceperson is in fact entitled to consult.

Conte found a useful suggestion for the NZDF from Noort's Case which used the section 5 of NZBORA justified limitations clause and what is suitable in a free and democratic society to limit legal access to telephone advice at the time of an alcohol testing regime. He said that when a serviceperson needs to consult a lawyer the NZDF could restrict this sub-right to telephone advice only 'because it takes into account discipline and the exigencies of the armed forces' and would be helpful in cases where the detainee is on active service or in a far-off posting (Conte, 1996: 103). He also noted in relation to fair trial and consulting a lawyer rights that the inquisitorial vs adversarial nature of military trials under the ADFA 1971 means that the usual cross-examination by lawyers is not permitted in summary disposals and therefore the accused cannot be fully represented by counsel (Conte, 1996: 161).

Conte believed that although this might be in breach of section 24(c) of NZBORA relating to persons charged having the right to consult and instruct a lawyer, a section 5 justified limitation could be argued by the NZDF to 'preserve the administrative efficiency' of summary disposals (Conte, 1996: 163). At the second reading of the Armed Forces Law Reform Bill 2007 the Hon Wayne Mapp (National MP) felt, however, that unless there were extreme circumstances (a combat ship at sea), service personnel should have the right to independent legal advice and the amended legislation eventually reflected this (Hansard 2007b: 4). The language used by the two researchers - Hook and Conte - is very much that of the human rights field. Drawing the concept of 'a right to a lawyer' and 'a right to independent legal advice' into the military justice system review opened up the discussion about the grey areas concerning the constitutional rights of service personnel. The NZDF internal review which followed explored this thoroughly, eventually resulting in the drafting of the Armed Forces Law Reform Bill 2007. 


\subsubsection{NZDF internal review}

Commander Christopher Griggs, undertaking research within the NZDF itself, noted that the implications of these international and domestic human rights instruments on the military justice system were unclear in the early 1990s. However, like Hook, he saw developments in Canada and the UK during the following decade which warned that challenges in this area could 'develop very quickly and have the potential to seriously undermine the military justice system' (Griggs, 2003: 1). By monitoring overseas experiences with the ICCPR and equivalent domestic legislation and constitutional documents (e.g. the Canadian Charter and NZBORA), the NZDF could foresee any likely challenges before the issues involved were tested in the courts. The military justice review, which began in 2002 with help from a number of government agencies, identified inconsistencies with NZBORA while preserving the 'vital elements' of the system i.e. maintenance of discipline, consistency, portability, expedition, fairness, efficiency and simplicity (Hook, 2002: 3-7). The review looked at a wide variety of issues: the right to legal representation and aid; restorative justice and victim's rights; the right to appeal; the right to natural justice; the conduct of prosecutions; arrest and questioning procedures; a joint system of summary disposals for the army, navy and airforce; a review of summary disposal systems; independent and impartial courts; and a permanent court-martial structure and reform of the court-martial systems (Griggs, 2003: Options Papers 1-30).

Conte, Hook and Griggs raised many issues that affected the individual rights of service personnel. By instituting its own internal review, feeding through information from independent researchers and consulting with other departments, the NZDF was able to proactively re-draft legislation to iron out inconsistencies between the outdated military code and the ICCPR and NZBORA. In particular, the NZDF took NZBORA rights very seriously and endeavoured to see how constitutional documents in other jurisdictions interacted with their military systems and international obligations. The language of NZBORA about 'justified limitations in a free and democratic society' has now penetrated into the military justice system, shining a human rights focus on a previously non-rights-based process.

Changes finally made as a result of the Armed Forces Discipline Amendment Act (No. 2) 2007 were: 
... the summary trial system will operate across all three services [army, navy, airforce]; there will be a right of appeal [to an independent civilian judge]; summary trial will be available for senior officers; a permanent, independent court martial will now exist, replacing temporary courts martial; two new offences of negligence will be introduced - negligently failing to perform a duty and negligent performance of a duty (NZDF, 2009a: 1).

On 9 July 2009 eight judges of the new Court Martial of New Zealand were sworn in at the High Court in Wellington, eight days after the new system officially came into effect on 1 July 2009 'to modernise and provide a fairer justice system for all military personnel' (NZDF, 2009a: 1; NZDF, 2009b: 1). This had been a very long journey to come to this stage as the issue had a 13-year incubation through various phases: the Conte and Hook research; the NZDF internal review; and the system overhaul and amending legislation. The process has come full cycle and the next section shows how it was viewed as a success by MPs on both sides of the House.

\subsubsection{Political support}

Once the Armed Forces Law Reform Bill 2007 was drafted the debate started in Parliament. ${ }^{165}$ At the first reading of the Bill the Hon Phil Goff (then Minister of Defence) noted that attitudes had changed enormously since the 1971 AFDA Act and that NZBORA rights needed to be observed. Condensing the issue succinctly he said:

... the military justice system today should apply to our armed forces personnel the same rights enjoyed by civilians in the criminal justice system, to the greatest extent possible consistent with the efficient and disciplined operation of the armed forces (Hansard, 2007a: 1).

The 'marching in time' concept of respecting individual rights while ensuring the defence of New Zealand outlined by Conte had therefore been recognised as possible. The Minister's comment highlights how far thinking in this area had changed to give rights pre-eminence instead of no place at all in the military justice system:

\footnotetext{
One of the principles that underpins many of the reforms in this bill is that the processes of the ordinary criminal law should be the benchmark for military law unless there are sound reasons arising from the nature of the armed forces that dictate otherwise (Hansard, 2007a: 2).
}

Like Conte he believed that the NZDF should defend why rights were to be breached, not the other way around. Not only was the Bill exemplary in its attempts to align

165 The Armed Forces Law Reform Bill 2007 was eventually split into four separate Bills: the Armed Forces Discipline Amendment Bill (No. 2); the Court Martial Appeals Amendment Bill; the Defence Amendment Bill (No. 3); the Court Martial Bill' before it was passed as the Armed Forces Discipline Amendment Act 2007 (Hansard, 2007c: 1). 
archaic military law with contemporary human rights law, it also became for politicians a very good example of sound and considered human rights policy making. The Hon Dianne Yates (Labour MP) for instance was especially positive about the quality of the Bill:

\begin{abstract}
I must say that a good deal of preparation has gone into this bill. It is one of the best pieces of legislation I have seen. The explanatory note is extremely good. Not only does it talk about the policy statement but also it outlines the public policy objectives, discusses the analysis of the clauses, and outlines the consultation processes. As I have said, this bill is one of the best pieces of legislation I have seen come before this House. It is a doorstopper. ... I recommend that those who are interested in legislation - and those who are drafting future legislation, take a good look at the explanatory note of this bill and at the actual structure of the bill itself (Hansard, 2007a: 4, 5).
\end{abstract}

The Hon Tim Barnett (Labour MP) also said: 'We as a House should recognise it [the bill] as a model of its type' (Hansard, 2007a: 13). This confirms the point that when human rights are factored in early in the process then policies develop 'which respect and reflect human rights' and 'are more likely to be inclusive, equitable, robust, durable and of good quality. Critically, such policies will also be less vulnerable to domestic and international legal challenge' (Ministry of Justice, 2000a: 95). The Hon Phil Goff also referred to the Bill as 'the product of four years of policy development' (Hansard, 2007b: 1). This, then, was a marriage of well-developed policy and well-drafted legislation, an excellent example of complementarity.

Tim Groser (National MP) also made the further important point that: 'Every major policy issue has to be looked at by each generation through their own eyes' (Hansard, 2007b: 7). This was because political and social changes, 'such as the enhanced role of women in the armed forces', meant policies have to be revisited from time-to-time (Hansard, 2007b: 7). Obviously the military justice system was well overdue for this review given the previous 1971 Act was over 30 years old. As this research shows, the field of human rights is an evolving one. One of the signs of robust human rights governance is the ability to have in place processes for stock-taking and planning when necessary to take account of changes in out-dated structures, laws or policies.

The Bill also found easy support on both sides of the House. Reflecting on the anomalies that had led to the drafting of the new legislation the Hon Wayne Mapp (National MP) said at the second reading of the Bill:

We owe it, as a House, to ensure that when people don the uniform in this country, they do not surrender their rights and privileges as citizens. We have to ensure that the armed forces law, which operates in obviously unusual circumstances, reflects those rights and privileges. One of those is to know that one will receive justice in the 
military chain of command (Hansard, 2007b: 3).

He went on to say that an individual's rights must always 'stand above' those of the 'cause of the service at large' (Hansard, 2007b: 4). The archaic, cut-off branch of military law that was operating well outside the principles of natural justice protected by civil law has finally been scrutinised and changed so that service personnel are not treated in an unfair or biased manner, and this has been given cross-party endorsement.

\subsubsection{Mainstreaming the changes}

While it took time to fine-tune the military justice system to align with international and domestic obligations, the reviews were carried out in a less pressured environment than the battleground of an expensive and public civil court case or under the shadow of an individual serviceperson taking a case to the UN Human Rights Committee under the Optional Protocol.

The benefit of the proactive approach therefore is that the layers are less complex (a four-stage instead of five-stage process - see Table 13) and that a measured approach can be taken to resolving potential rights infringements. This 'expected' new issue into the state sector involved much less turbulence than the 'non-expected' Baigent's Case to reach a point where the changes involved were mainstreamed. After Baigent it took some time for the state sector (in particular the NZ Police) to realise it was not going to be a costly decision for departments, nor was it going to disrupt everyday operational procedures to any great extent. Critically the expensive 'Stage I: Alienation - Panic Rejection' which was present in Baigent was not evident in the military justice review case. Nor was there any need for the long period of acceptance. Instead the first stage that the military justice review entered seemed to go straight into acceptance as it became immediately clear from the work done by Conte, Hook and Griggs that the outdated system was in urgent need of an overhaul. Once the scope of this had been assessed it was then possible to move easily into the second stage of modification. From there further stages of implementation (particularly the 1 July 2009 roll-out of the new military justice system) and assimilation have also happened in a timely manner. The changes are now mainstreamed into both policy and legislation: hence complementarity.

However, it is possible to have substantial resistance from within an organisation to major legislative/policy reviews and institutional restructuring, particularly in relation to cost. In such a case the 'Stage I: Alienation-Panic-Rejection' would be 
carried out informally, and it would come down to the persistence of the core leadership in the area that this stage does not become formalised (as it did with the NZ Police response to Baigent). This confirms a point made earlier about the need for a rightsliterate policy advisor network. It also affirms the findings of this research that when good policy analysis is carried out in conjunction with the bedrock law+litigation approach, then there are fewer inconsistencies between international human rights obligations and domestic laws and policies. In the military justice case, individual legal officers were highly aware of the legal consequences of the international framework interacting with existing domestic military laws and regulations and they acted as advocates to press that the rights of individual soldiers were not violated. Unlike Baigent, the military justice review was therefore proactive and protective of New Zealand's possible breaches of the ICCPR.

Table 13. Mainstreaming process - military justice system

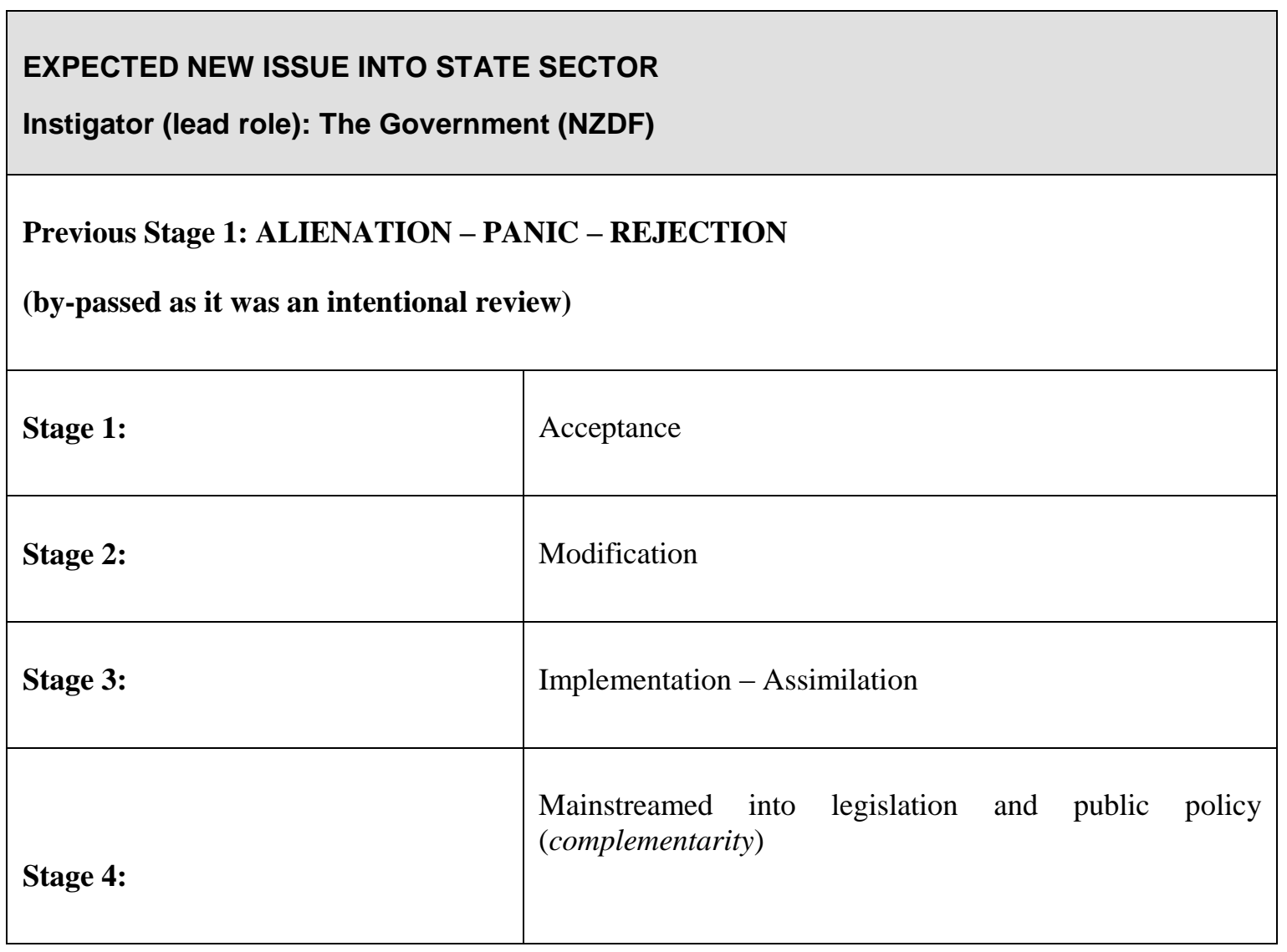




\subsection{Human rights governance level interactions}

These two cases, along with a third case Taunoa $v$ Attorney-General, will now be examined together. This will reveal the presence of a human rights governance level made up of several interacting factors all linked to the international human rights system (see Figure 2).

Baigent was a case that had a panic effect on the state sector in New Zealand until the rhetoric and implications of the decision had time to settle down. It is now being cited in other jurisdictions as a 'test case'. It can be seen from Section 8.1.5 that courts in other countries are also grappling with the issue of how best to deal with breach of remedies for bills of rights and the New Zealand approach is being looked at. However, this research suggests that Baigent is not being looked at carefully enough i.e. behind the layers of rhetoric and panic and the law+litigation approach and into a deeper analysis of what actually happened at other levels such as policy and fiscal reality. The reason why other jurisdictions cannot carry out a deeper analysis is because it has not been done in New Zealand, and it is hoped that the value of this research is that it does peel back the layers to show what really occurred. This clearer picture then enables several conclusions to be reached:

- far from being perceived as something of a disastrous decision, which sent panicked shock-waves through the state sector, it did actually uphold the rights of the individual citizen as set out in the ICCPR

- it was also an effective decision in that it caused the NZ Police to look seriously at search and warrant procedures, which until the monetary damages were introduced were not being carried out as well as they could have been

- it further showed the political response brought a measured calm to the panic. It could have been that Cabinet joined the NZ Police in the 'Stage I: Alienation Panic - Rejection' reaction but did not. The decision to proceed carefully and then not to repeal the legislation meant that after a time "Stage 2: Acceptance" was able to begin and thereafter Stages 3 and 4. The political response was therefore one of de-escalation of panic 
- with hindsight it can be seen that the rhetoric of panic and a knee-jerk reaction is not best practice and the question needs to be asked: 'What response should occur under robust human rights governance?' There was a dual response to Baigent: a fragile/weak response by the NZ Police; and an eventual robust response at the political level through Cabinet. In an ideal world and in a truly robust human rights state all responses from all parties would be robust.

Since Baigent another case - Taunoa - has been awarded Baigent damages, but in this instance the political response went in a different direction. ${ }^{166}$ In Taunoa, prisoners who were forced to be on a 'Behaviour Management Regime' were jointly awarded $\$ 130,000$ damages for inhumane treatment, which breached both prison regulations and NZBORA. However, this time public outrage influenced political action, and the case was instrumental in the development of the Prisoners and Victims Claims Act 2005 which enables compensation to go to the victims of these prisoners instead of to them directly. ${ }^{167}$ This highlights further concluding points:

- in a democracy, political and/or public responses can be large factors in some cases

- in a sense it gave weight to the NZ Police Chief Legal Advisor (DB Kerr's) fears that penal institutions would have to treat prisoners with 'kid gloves'. With a growing rights environment in the state sector, it was only a matter of time until prisoner's rights (which have long been a concern of the UN Human Rights Committee) would take centre stage. This has parallels with the military justice case study, where the human rights of military personnel finally became centre stage after a long history of non-recognition

- other wider debates (such as law and order and tougher sentencing) can also cut across cases like Taunoa, so there is a dynamic picture emerging with a number of intersecting points.

166 There have been a number of Baigent awards since the Simpson v Attorney General case, including Taunoa v Attorney-General (2004) 7 HRNZ (HC)

167 For a further discussion on this case see Butler who noted that under the 2005 Act 'the right of prisoners to compensation for violation of his or her BORA rights while in prison is not removed: rather the Act "only" gives victims the right to "share" in the proceeds of the rights violation' (Butler, 2006: 25). 
This dynamic picture can be described as a human rights governance level. It works for both Baigent and Taunoa, as well as for the military justice case study.

\begin{tabular}{|c|c|c|}
\hline $\begin{array}{c}\text { POLICY } \\
\text { (State sector response) }\end{array}$ & $\begin{array}{c}\text { INSTITUTIONAL } \\
\text { (Organisation and governance) }\end{array}$ & $\begin{array}{c}\text { IMPLEMENTATION } \\
\text { (Of legislation and policies by } \\
\text { state sector) }\end{array}$ \\
\hline $\begin{array}{l}\text { PUBLIC VALUES } \\
\text { (Expectations) }\end{array}$ & $\begin{array}{c}\text { INTERNATIONAL HUMAN RIGHTS } \\
\text { SYSTEM }\end{array}$ & $\begin{array}{l}\text { ENFORCEMENT/REMEDIES } \\
\text { (Courts) }\end{array}$ \\
\hline $\begin{array}{c}\text { POLITICAL } \\
\text { (Cabinet response) }\end{array}$ & & $\begin{array}{l}\text { LEGISLATION CREATED } \\
\text { (Parliament) }\end{array}$ \\
\hline \multicolumn{3}{|c|}{$\begin{array}{l}\text { MAINSTREAMING } \\
\text { PROCESS } \\
\text { (Of issues generated from various actors e.g. the government, Courts) }\end{array}$} \\
\hline
\end{tabular}

Figure 2. Human rights governance level interactions

In Baigent all the factors in the case were intersecting at the human rights governance level:

- in relation to 'Legislation', NZBORA was set up with its link in the long title to the rights in the ICCPR

- this provided a basis for the 'Enforcement' part of the human rights governance level (the courts) to then make decisions based on the link between domestic law and international human rights obligations. The courts were also instrumental in providing 'Remedies'

- the decision caused panic in the 'Implementation' arm of the state sector, in particular the NZ Police 
- 'Public values' were important in Baigent because it involved the wrongful search of a member of the public, and it brought to light what was felt to be acceptable or not in this regard

- the 'Political' response was not to be defensive or alarmist, but to take advice and not repeal the legislation. That is, the approach was to effectively ride out the panic and see that it was not going to have the disastrous consequences at first thought

- the 'Policy' response was that the NZ Police, in particular, eventually provided much more internal information to officers about breach of NZBORA rights and actual procedures were from that time carried out more stringently to avoid Baigent damages

- as a result of the decision, 'Institutional organisation and governance' strengthened. This was because (as noted in Section 8.1.2) a large number of departments were involved in the state sector response and there now exists a way of dealing with such decisions

- eventually a 'Mainstreaming' process occurred as the issue became assimilated through the state sector.

\section{In Taunoa:}

- the 'Legislation' part again involved NZBORA and the ICCPR

- this also provided the basis for the 'Enforcement' part (the courts) to make a decision based on the link between domestic law and international human rights obligations. In this case there was also a Baigent 'Remedy' provided by the courts

- this time the decision did not cause panic in the 'Implementation' arm (the state sector)

- instead it caused outrage in the 'Public values' arm

- this in turn caused the 'Political' response to come up with a compromise (the Prisoners and Victims Claims Act 2005) 
- the 'Policy' response was that the Department of Corrections would look more carefully in the future at instituting policies such as the Behaviour Management Regime

- the 'Institutional organisation and governance' aspect had already been strengthened by the state sector's Baigent experience

- the 'Mainstreaming' process only occurred after all these factors had settled down.

In the military justice case study:

- the 'Legislation' part also involved NZBORA (with its link to the ICCPR) and out-dated military justice legislation was eventually amended

- this also provided the basis for the 'Enforcement' part (the military court system) to be reviewed so there was an alignment between domestic law and international human rights obligations. There were no 'Remedies' involved in this case

- this time the decision did not cause panic in the 'Implementation' arm (the NZDF)

- this case did not stir up issues at the 'Public values' level

- the 'Political' response was very supportive and the amending legislation was endorsed by all parties in the House

- the 'Policy' response was to have policies and practices amended in line with NZBORA and the ICCPR

- as a result of this military justice system review, 'Institutional organisation and governance' was strengthened. This was because (as noted in Table 12) the review was the result of a collaborative effort between number of agencies

- there was also one less level involved in the 'Mainstreaming process', because the panic of Baigent did not occur.

Looked at as a whole, this human rights governance level shows that for a deeper 
analysis to be carried out, all factors need to be examined individually and in concert. Different parts of it will be prominent in different cases and best practice occurs when each part is operating in a considered, instead of knee-jerk, manner in relation to human rights issues that arise in the state sector. It is also the case that all parts of the human rights governance level are closely linked to the international human rights system:

- 'Legislation' ensures consistency between domestic laws with international human rights obligations

- the 'Enforcement' part (the courts) act as the interpreters of these obligations; and sometimes provide 'Remedies'

- the 'Implementation' arm (the state sector) is required to give effect to these obligations in all its policy and legislative work

- individuals collectively express 'Public values' and are able (under some covenants) to seek individual redress at the UN, and to expect that their rights under ratified treaties across a wide range of areas are protected

- the 'Political' part is acutely aware that the international dimension impacts closely on the domestic and that all decisions must be taken into account with this in mind

- the 'Policy' arm also has to take account of international obligations in everyday work, hence the need for early mainstreaming

- the domestic 'Institutional organisation governance' part is closely tied to the international human rights framework.

This links back to an earlier discussion in Chapter 1.2.2 where the concept of complementarity was introduced. It has already been suggested that underlying the New Zealand approach to fulfilling obligations has been the interaction between international processes and domestic constitutional, law and bureaucratic systems and that this can best be understood using the metaphor of 'weaving'. Figure 2 is an illustration of how intermeshed the international-domestic spheres have become, to the point where they 
cannot be seen as distinct from one another. ${ }^{168}$ This shows that the work that has been done to align the international and domestic spheres resonates across the state sector, and that the effects on one area can be felt in another.

The issue of the relationship between public policy and human rights can now be returned to in light of the concept of a human rights governance level. A purely instrumentalist, standard approach to public policy - having an issue, stating the problem, and finding a solution - is inadequate to deal with the complexities and multidirectional influence of the human rights governance level. Closer resonance can be found in Mark Considine's alternate view that suggested that public policy is the continuing work done by groups of policy actors who use available institutions to articulate and express the things they value' (Considine, 1994: 4). He further talked of policy culture (values). Figure 2 conceptualises an ongoing dynamic between domestic and international human rights actors, institutions and values. It also fits with his definition of policy systems, which 'need to be understood as complex structures for political learning and memory' (Considine, 1994: 47). As Chapters 3-6 in particular show, the build-up of (and constant changes made to) the international and domestic human rights framework involve political learning and memory. As each issue or episode arises, for instance these two case studies, lessons are learned and political memory grows strategies to deal with similar situations (for example, much was learned from Baigent).

\subsection{Summary}

There are points of similarity between the two case studies. The military justice review and Baigent are both examples of loopholes in the system where individuals could have taken cases to the UN Human Rights Committee under the Optional Protocol to the ICCPR. In both instances domestic legislation and policy were out of alignment with international law. At each of the levels it has been identified in both examples (covenant-statute-judicial-Cabinet/departmental/policy-individual) there was a lack of

\footnotetext{
168 There has also been a different type of interweaving, as Baigent was cited by one of the NZDF researchers in his conclusion: 'On another level, several motivating factors arise from the practical consequences of acting in breach of the NZBORA. In the majority of cases, such action can result in the inadmissibility of evidence or, in the worst case, might result in the invalidation of the entire process in question. However, the sting of the Act does not end there. Since the Court of Appeal judgment in Baigent's Case, the Defence Force must also be wary of its liability for damages under the Act' (Conte, 1996: 202).
} 
clarity to a seamless covenant fulfillment in the domestic arena. It was noted earlier that during the 1940s New Zealand had urged the necessity for individuals to be able to petition the UN directly. Ironically part of the problem in each case was that individuals would have had better protection through the international committee than redress through the domestic civil and military justice systems - a long detour and not a smooth passageway for the implementation of human rights in this country. Both case studies also highlighted that policy/legal advisors/service personnel are operating in an international and domestic bill of rights climate, and the result has been heightened respect for the ICCPR and NZBORA in their work. Looked at together the cases are a lesson that early mainstreaming of human rights considerations in the policy-making process, and ironing out inconsistencies with ratified international human rights instruments, are more cost-effective for the state sector than not carrying out these initiatives. Policy advisors also need to be aware of constitutional rights and freedoms which is why an effective human rights training programme for them should also include a thorough grounding in New Zealand's constitutional arrangements and the protections this gives individual citizens.

However, the differences between the two case studies were marked in terms of their impact on the state sector. The reactive Baigent's Case caused turbulence at many levels: in the relationship between Parliament and the judiciary; for many government departments as they scrambled to estimate the potential costs of the new damages; and for the NZ Police in particular as it affected the everyday work carried out by officers. This case was like a grenade that had panic effects that resonated throughout the state sector. These shock waves were even felt in Australia where Baigent has been used as a warning case (a possible 'what not to do' example) in the development of federal bills of rights. However, as just noted Australian commentators have only ever been presented a 'surface' view of what actually happened, and this thesis has been able to give a deeper analysis of the factors surrounding the case. On the other hand the proactive military justice review stands out as being the most considered, the least disruptive for the state sector, and the most comprehensive. At the second reading of the Armed Forces Law Reform Bill 2007 the Hon Wayne Mapp commented:

Had the director of legal services for the armed forces, Brigadier Riordan, and his team, and, particularly, the naval commander [Griggs], not taken the initiative, we would not be dealing with this legislation today (Hansard, 2007b: 3).

That is, proactivity needs leadership, foresight and the resources to thoroughly assess 
all domestic legislation (civil and military) against international law. The review was carried out after other jurisdictions had been down similar routes and made mistakes that New Zealand could beneficially learn from at a distance, so in this case other countries became 'what not to do' examples for us. A further reflection on Baigent is that despite the potential charge of judicial activism, it can be seen that the courts were 'taking the lead' in ensuring policy and legislation complied with international standards in a way that the government cannot always do. The policy-making arms of government (the legislature and executive) are more widely accountable, and are therefore more influenced by public opinion than the courts. The government resisted any pressure to repeal the decision, but the question needs to be asked: would the government have introduced Baigent-type damages, given its initial unpopularity? It is doubtful this would have happened, which is why the courts became the vehicle to do this. A similar instance was Brown v Board of Education (1954), the landmark case where the USA courts took a leadership role in declaring racially segregated schools as unconstitutional. This would have been a politically contentious issue, and the courts again became the instigators for this broad policy change.

Also the human rights governance level has shown that several factors - 'Legislation', 'Enforcement', 'Implementation', 'Public values', 'Political', Policy' and 'Institutional organisation and governance' - all intersect with the international human rights system to react to issues that arise in the state sector. It is possible to list 20 criteria to broadly assess effectiveness to get a clearer picture of New Zealand's robustness as has been done in Chapter 7. To obtain an even more detailed understanding of this robustness, it has been necessary to uncover the dynamic that is operating between the various parts of the human rights governance level. This has been well illustrated by examining particular cases that have impacted on the state sector (such as Baigent, Taunoa and the military justice system review). This research also shows that the standard public policy view is inadequate to deal with this multi-faceted and dynamic human rights governance level. The work of Considine (1994) does, however, resonate and helps to understand this area of policy.

Having presented the case studies - which show in the military justice system review a more fine-tuned illustration of complementarity working well - Chapter 9 now turns to the concluding comments. 


\section{CHAPTER 9: CONCLUDING COMMENTS}

\subsection{General findings}

Robust human rights governance is not of course perfection, nor does it require constant harmony with all views of UN treaty body monitoring mechanisms. For example, New Zealand has a different perspective to the UN on the unentrenched status of human rights as set out in NZBORA. Another example concerns the justiciability of second generation rights. Compliance does not necessarily mean absolute uniformity, with some room for 'doing' human rights in a local context. As the two case studies have shown, the human rights framework is 'self-correcting'. There was a problem in each instance, but the architecture was in place to close the gap and address the issue. One (Baigent) was time-consuming and costly and involved a court case. The other (military justice system review) was considered and carried out without the cost of a potential breach being tested in the courts. One was reactive and the other proactive, but this 'rebalancing' nevertheless occurred in both cases. Put another way, when rights seem to be breached the New Zealand framework is able to 'stand upright in the winds that would blow'. 169

Another finding of this research is that rights need to be respected before they are workable: they assume the operation of the rule of law and a well-informed 'rights conscious' citizenry. Even so, things go wrong and the key then is the capacity for correction. Thus in Baigent an allegedly casual attitude by a police officer, and a determined response from a concerned citizen, produced not only a judicial response of damages, but more awareness by the NZ Police in particular about the effect of NZBORA and the ICCPR. Similarly, the military justice system case study shows the importance of a rights-literate NZDF and rights-literate service personnel in their dual role as citizens/soldiers, and the cut-off point for when the issue of discipline could impinge on rights. This second case study illustrates that proper implementation is possible if the law+litigation and policy fields are aligned, which means the circumstances favouring complementarity are present. The case studies also show that 
the state sector can work towards robust human rights governance when there is a best practice approach to issues as they arise, or towards a fragility or weakness when there is a panicked knee-jerk response to them.

Why is complementarity taking place? This research suggests it is part of a natural evolution of domestic human rights frameworks as they change and grow and (ideally) become more robust. New Zealand's framework developed slowly over decades, suggesting that its robustness has occurred through incremental changes. The stepping back and 'taking stock' of the last several years was arguably necessary for the entire human rights environment to be reassessed. New, more active, ways of proceeding are starting to be put in place. Action plans are also being used as tools to progress or grow the realisation of rights in this country. This approach mirrors the preamble of the ICESCR that urges each state party to undertake steps to 'progressively achieve' the full realisation of rights in the covenant. This factor was also a defining feature of the distinction between the human rights and public policy fields clarified at the beginning of the research. Mark Considine (1994: 7) noted this when he said:

\footnotetext{
Governments do not start and stop a commitment to a policy area; rather, they modify, prune and adjust. Key interests rarely leap from one ideological position to something entirely different. They amend, reorganise and re-position through smaller steps.
}

Big bangs of reform or change in constitutions make good copy for newspapers. But there is at least a plausible case to be made that the path towards robust human rights governance is a progression of small movements and incremental changes that over time build a stronger framework. Looking back over this country's history, the progress did not occur by accident. New Zealand's historical experience was in part shaped by Prime Minister Peter Fraser, especially his views on the role of the state in achieving human dignity after the Great Depression of the 1930s. This informed his views at the end of World War II, particularly his championing of what were to become second generation human rights. The steady progression of steps that have been charted here echo the comments of the NZ Constitutional Arrangements Committee about the constitution more generally, and their description of a 'process of pragmatic evolution' certainly describes the human rights history of New Zealand:

\footnotetext{
Constitutional issues are subtle and interlinked, and New Zealand's strong tradition has been to deal with them piece by piece, through a process of pragmatic evolution over time (NZ Constitutional Arrangements Committee, 2005: 9).
}

As an architect of the human rights framework, New Zealand was perhaps always more 
likely to be a willing subject of it, although not all founding members of the UN have been so supportive of this framework (including the USA). The process has therefore been interactive between international law and domestic implementation as New Zealand was (and is) a 'maker' as well as a 'taker' of the international processes. Even for states with close historical and political parallels, the exact processes for domestic implementation are also likely to differ. The differences will also be even more marked for states with significantly different histories, capacities, willingness and systems for implementation. The complementarity metaphor might also highlight the fragility of effective implementation in some developing states, and hence the concept of fragile (vs robust) human rights governance. It has been suggested too that New Zealand has its own fragility in its generally strong human rights framework with the areas that are still developing, weak or non-existent. A domestic human rights system works best when there is a central agency or working group with oversight for this topic; when no such entity exists then fragmentation occurs. Following on from this, the combination of the practical tool of a phased history and a new understanding about a human rights governance level (with criteria for judging effectiveness) could also act as a template for other countries on a currently fragmented human rights journey. Using this combination, Pacific Island states or small emerging nations for instance could possibly see more clearly what international best practice in the implementation of ratified treaty rights might look like.

The metaphor of waves was used at the outset of the research: the first wave in the 1940s setting up the international human rights framework; the second in the 1970s where there was a flurry of domestic human rights-related institution building and legislation; the third of 1994-2009 when the stock-take and planning initiatives were carried out; the fourth wave of trying to implement rights more effectively; and the fifth of actively setting up robust human rights governance. In relation to this last wave this research shows that effectiveness in achieving a robust human rights state is highly nuanced. It requires many of the couplets set out in the research - internationaldomestic, law-policy, rhetoric-action, proactive-reactive - to be in good alignment. On top of these complexities there also needs to be an accommodation of the rights generational dimensions. Instead of many developments happening at once, though, there is a sense of minor but complex and convergent wave patterns within each of the five major waves just described. 


\subsection{Original and significant contributions}

The original and significant contributions of the research can now be summarised. The relationship between human rights and public policy has been examined in a way that has not been carried out before. The research broadly looks at the human rights field and its increasing importance within and to the side of the public policy field.

New concepts have been introduced. For instance, complementarity, which suggests that the more effective implementation of human rights occurs when the two fields of law+litigation and public policy are fully aligned. It also introduces the notion of a 'human rights governance level', and locates its position at the intersection of a number of factors which link to the international human rights system - institutional, political, legal, policy, enforcement, implementation and public values. The research develops the notion of governance further by introducing the concept of robust human rights governance, and its opposite, fragile human rights governance.

The staged development of New Zealand's human rights history has been set out in a way that has not been carried out before, and criteria have been developed against which to assess effectiveness as a robust human rights state. Chapter 4 has documented, for the first time, the large volume of work done in the stock-taking and planning initiatives of 1994-2009. The research both identified this as a unique phase of development in New Zealand's human rights history, and found that while there have been advances, there are still many problems to be resolved. Insights from the public policy field about whole-of-government collaboration were linked with ideas for interagency coordination on human rights issues.

Links have been made with the constructs in this research and the public policy literature. It has been noted that the standard view of public policy is inadequate to deal with the multi-directional human rights governance level. The thesis has also identified that although authors such as Mark Considine do not examine human rights as an area of public policy, his alternative theory does accommodate the complexities of the human rights governance level introduced in this research.

The two case studies were used to show how human rights issues can be mainstreamed in the state sector, and that if this happens proactively it takes less time for this 
mainstreaming to occur. The Baigent case study uncovered unpublished material which contributes to the scholarship on this decision.

Finally, the two frameworks (the staged history and the effectiveness criteria) also provide analytical tools which may help other states. With its synthesising and analytical components, this research could also contribute to the human rights field in New Zealand.

\subsection{Summary}

To summarise, this thesis began by suggesting that although New Zealand appeared to have a well-developed domestic human rights architecture reflected in institutions, laws and policies and an endorsement of international standards, what was lacking is a means to judge the effectiveness of the achievements to date and to recommend areas for improvement. As a contribution to the field a six-phase New Zealand human rights history has been suggested as a way of gaining a better picture of the development of this area over several decades. The concept of robust human rights governance was then introduced, which is also the sixth stage of the historical phases. Looking at the 20 criteria for effectiveness it was found that although New Zealand has reached the most robust stage there is still room for improvement. It was also suggested that a human rights governance level is lacking in the state sector. This research has therefore provided constructs which show that if what might appear to be a rather ad hoc human rights system is examined, a 'whole' can actually be found that is well described by the concept of complementarity. New Zealand's own developing practice reveals complementarity + effectiveness in the evolving human rights framework and approaches. Most particularly, it reveals the need now for a fuller integration of the law+litigation and public policy approaches in order for ratified treaty rights to be more effectively implemented through the New Zealand state sector. 


\section{REFERENCES}

Abbott, K. and Snidal, D. (2000). 'Hard and Soft Law in International Governance'. International Organization 54(3): 421-456.

Allan, James and Geddis, Andrew. (2006). 'Waldron and Opposing Judicial Review Except, Sort Of, In New Zealand'. NZLJ 94-96.

Alley, Roderic (Ed). (2009). Celebrating Human Rights: Sixty Years of the Universal Declaration: Proceedings of the Wellington Conference. NZ Human Rights Commission and NZ Institute of International Affairs: Wellington, NZ.

Alston, P. (2005). Non-State Actors and Human Rights. OUP: Oxford, UK.

Alston, P. and Crawford, P. (Eds). (2000). The Future of UN Human Rights Treaty Monitoring. CUP: Cambridge, UK.

Alston, P. and Megret, F. (Eds). (2009). The United Nations and Human Rights: A Critical Appraisal. OUP: Oxford, UK.

Alvesson, M. and Skoldberg, K. (2000). Reflexive Methodology: New Vistas for Qualitative Research. Sage Publications: Thousand Oaks, CA, USA.

Amesbury, Denise (National Manager Training, Department of Corrections). (2009). Personal communication (email dated 27 October 2009).

Amnesty International, Development Resource Centre, Human Rights Commission, Office of the Children's Commissioner and Peace Foundation. (2007). Building Human Rights Communities in Education. HRC: Wellington, NZ.

Arnold, Terence. (2005). 'Parliament and the Courts: Arm Wrestle or Handshake?' New Zealand Journal of Public and International Law 3(1): 45-61.

Aspey, Ann (State Services Commission). (2008). Personal communication (letter dated 26 August 2008 as a result of an Official Information Act request).

Australian Government. (2009). Statement on the United Nations Declaration on the 
Rights of Indigenous Peoples. Australian Government: Canberra, Australia.

Bassett, Michael. (2001). Tomorrow Comes the Song: A Life of Peter Fraser. Penguin Books: Auckland, NZ.

Beetham, David. (1995). 'What Future for Economic and Social Rights?' Political Studies 43 (Special Edition): 41-60.

Bell, Christine. (2008). On the Law of Peace - Peace Agreements and the Lex Pacifactoria. OUP: Oxford, UK.

Beresford, Stuart (Bill of Rights Team, Ministry of Justice). (2008). Personal communication (letter dated 7 August as a result of an Official Information Act request).

Biggs, Susan (Manager, Strategic Policy Team, HRC, Wellington, NZ). (2008). Personal communication (letter dated 23 September 2008 as a result of an Official Information Act request).

Black-Branch, Jonathan. (2009). 'Human Rights Protection in Europe'. Presentation at Victoria University Law School (27 August 2009), Wellington, NZ.

Blaikie, Norman. (2000). Designing Social Research. Blackwell Publishers Ltd: Oxford, UK.

Bolt, Robert. (1990). A Man for All Seasons: A Play in Two Acts. Vintage Books: UK.

Borelli, Silvia. (2006). 'Positive Obligations of States and the Protection of Human Rights'. Interights Bulletin 15: 101-103.

Boyle, Alan and Anderson, Michael (1996). Human Rights Approaches to Environmental Protection: An Overview. OUP: Oxford, UK.

Bradford, M. and Scott, G. (2009). Developing Robust Economic Governance Systems: A Project for the World Bank MDTF for Research and Knowledge Work on Fragile States. Final Report - Volume 1: Main Report. Report to the Fragile States Unit of OPCS. The World Bank: Washington DC, USA. 
Brownlie, Ian. (2008). Principles of Public International Law (7th Edn). OUP: Oxford, UK.

Bryson, J.M., Crosby, B.C. and Middleton Stone, M. (2006). 'The Design and Implementation of Cross-Sector Collaborations: Propositions from the Literature'. Public Administrative Review (Special Issue: 44-55).

Budlender, Geoff. (2006). 'Implementing Judgments on the Positive Obligations of States'. Interights Bulletin 15: 139-140.

Butler, Andrew and Butler, Petra. (2005). The New Zealand Bill of Rights Act: A Commentary. LexisNexis: Wellington, NZ.

Butler, Petra. (2004). 'Human Rights and Parliamentary Sovereignty in New Zealand'. VUWLR 35: 341-366.

Butler, Petra. (2006). ' 15 Years of the NZ Bill of Rights: Time to Celebrate, Time to Reflect, Time to Work Harder?' Human Rights Research HRR1 2006. Paul Morris and Helen Greatrex (Eds) (can be accessed as an online journal at www.victoria.ac.nz/nzcpl/).

Byrne, Iain. (2005). 'Making the Right to Health a Reality: Legal Strategies for Effective Implementation'. Paper presented to Commonwealth Law Conference (September 2005), London, UK.

Cabinet Office. (2001a). Cabinet Policy Committee Paper POL (01) 101: Human Rights: Related Human Rights Issues (17 May 2001). NZ Parliament: Wellington, NZ.

Cabinet Office. (2001b). Cabinet Policy Committee Minute of Decision POL (01) 12/11: Human Rights: Related Human Rights Issues (23 May 2001). NZ Parliament: Wellington, NZ.

Cabinet Office. (2006). Cabinet Paper SDC (03) 139: Negotiations on a Convention on the Rights of Disabled People. NZ Parliament: Wellington, NZ.

Cabinet Office. (2007). Cabinet Paper SDC (03) 54: Development of the UN Proposed Convention on the Rights of Disabled People: New Zealand's Role. NZ Parliament: 
Wellington, NZ.

Cabinet Office. (2010a). CabGuide: Guide to Cabinet and Cabinet Committee Processes. NZ Parliament: Wellington, NZ.

Cabinet Office. (2010b). Cabinet Manual. NZ Parliament: Wellington, NZ.

Cassese, Antonio. (2005). International Law ( $2^{\text {nd }}$ Edn). OUP: Oxford, UK.

Cheung, Amanda (NZ Immigration Service). (2009). Personal communication (email dated 23 December 2009).

Chinkin, C.M. (1989). 'The Challenge of Soft Law: Development of Change in International Law'. International and Comparative Law Quarterly 38: 850-866.

Clark, Roger. (2000). 'How International Law Affects Domestic Law'. In Human Rights: New Perspectives, New Realities. Admantia Pollis and Peter Swab (Eds). Lynne Rienner Publishers: London, UK.

Clough, Peter and Nutbrown, Cathy. (2002). A Student's Guide to Methodology. Sage Publications: Thousand Oaks, CA, USA.

Commonwealth Secretariat. (2001). National Human Rights Institutions: Best Practice. Legal and Constitutional Affairs Division, Commonwealth Secretariat: London, UK.

Conde, Victor. (2004). A Handbook of International Human Rights Terminology. University of Nebraska Press: Lincoln, USA.

Considine, Mark. (1994). Public Policy: A Critical Approach. MacMillan Education Australia Pty Ltd: Melbourne, Australia.

Conte, Alex. (1996). The Impact of Human Rights on Military Discipline in New Zealand: Marching in Time. LLM Thesis, Victoria University: Wellington, NZ.

Coomans, Fons (Ed). (2006). Justiciability of Economic and Social Rights: Experiences from Domestic Systems. Intersentia: Oxford, UK.

Covell, Katherine and Howe, Brian. (2007). Empowering Children: Children's Rights Education as a Pathway to Citizenship. University of Toronto Press: Toronto, Canada. 
Covell, Katherine and Howe, Brian. (2008). Rights, Respect and Responsibility: Final Report on the County of Hampshire Rights Education Initiative. Cape Breton University: Nova Scotia, Canada.

Crotty, Michael. (1998). The Foundations of Social Science Research: Meaning and Perspective in the Research Process. Allen \& Unwin: Crow's Nest, NSW, Australia.

Crown Law Office. (2005). The Judge Over Your Shoulder: A Guide to Judicial Review of Administrative Decisions. CLO: Wellington, NZ.

Cubitt, Adele. (2004). Making International Human Rights Obligations a Reality Through the Development of National Action Plans: New Zealand's Example. LLM Research Paper, Victoria University Law Faculty: Wellington, NZ.

Cusac, Anne-Marie. (2009). Cruel and Unusual: The Culture of Punishment in America. Yale University Press: New Haven, USA.

Dean, Hartley. (2007). 'Social Policy and Human Rights: Re-thinking the Engagement'. Social Policy and Society 7: 1-12.

Department for International Development. (2005). Why Do We Need to Work More Effectively in Fragile States? DFID: London, UK.

Department of External Affairs. (1945). 'United Nations Conference on International Organisation: Report on the Conference held at San Francisco 25 April - 26 June 1945 by the Rt Hon Peter Fraser - Chairman of the New Zealand Delegation'. Department of External Affairs Publication No. 11. DEA: Wellington, NZ.

Department of External Affairs. (1948). New Zealand's Human Rights Speech to the UN General Assembly on 9 December 1948 (Colin Aikman speech). DEA: Wellington, NZ.

Department of Justice. (1985). A Bill of Rights for New Zealand - A White Paper. Government Printer: Wellington, NZ.

Donnelly, Jack. (2003). Universal Human Rights in Theory and Practice. Cornell University Press: Ithaca, NY, USA.

Donnelly, Jack. (2007). International Human Rights. Westview Press: Cambridge, MA, 
USA.

Early Childhood Development. (2002). A Draft Charter of the Rights of the Mãori Child: Te Mana o te Tamaiti Māori. Wellington, NZ.

Eichelberger, Clark. (1944). Proposals for the United Nations Charter: What Was Done at Dumbarton Oaks. Commission to Study the Organisation of Peace: New York, USA.

Eid, Elizabeth. (2001). Interaction Between International and Domestic Human Rights Law: A Canadian Perspective. Paper presented at the Sino Canadian International Conference on the Ratification and Implementation of Human Rights Covenants (October 2001), Beijing, China.

Elkind, Jeremy. (1995). 'Baigent - An Analysis'. Human Rights Law \& Practice 1(3): 148-156.

Eppel E., Gill, D., Lips, M. and Ryan, B. (2008). Better Connected Services for Kiwis: A Discussion Document for Managers and Front Line Staff on Better Joining Up the Horizontal and the Vertical. Institute of Policy Studies, School of Government, Victoria University: Wellington, NZ.

Evans, Carolyn. (2004). 'Responsibility for Rights: The ACT Human Rights Act'. Federal Law Review 13: 1-19.

Evans, Malcolm (Ed). (2006). International Law (2 ${ }^{\text {nd }}$ Edn). OUP: Oxford, UK.

Fawthorpe, Helen. (1995). 'Human Rights'. In New Zealand as an International Citizen: Fifty Years of United Nations Membership. MFAT: Wellington, NZ.

Fletcher, Michael and Dwyer, Maire. (2008). A Fair Go for all Children: Actions to Address Child Poverty in New Zealand. Office of the Children's Commissioner and Barnardos: Wellington, NZ.

Forster, C. and Morris, A. (Eds.) (1991 ongoing). Australian Journal of Human Rights. Australian Human Rights Centre, University of New South Wales Law Faculty: Sydney, Australia.

Francioni, Francesco and Conforti, Benedetto. (1997). Enforcing International Human 
Rights. Kluwer Law International: The Hague, The Netherlands.

Gearty, Conor. (2010). 'Terms of Art'. London Review of Books 32(5): 27-29.

Geiringer, C. and Palmer, M. (2003). Issues Paper: Applying a Rights-Based Analysis to the Development of Social Policy in New Zealand (Report to the Human Rights Commission). NZ Centre for Public Law, Victoria University: Wellington, NZ.

Geiringer, C. and Palmer, M. (2007). 'Human Rights and Social Policy in New Zealand'. Social Policy Journal of New Zealand 30: 12-41.

Gomm, Roger. (2004). Social Research Methodology: A Critical Introduction. Palgrave Macmillan: New York, NY, USA.

Graham, Rt Hon Douglas. (1998). Human Rights Amendment Bill: Briefing Material. NZ Parliament: Wellington, NZ.

Greatrex, Helen. (2009). 'Embedding a Human Rights Approach into the Public Sector'. Paper (unpublished) presented to meeting of HRC National Strategic Policy Managers in Auckland, NZ on 16 June 2009.

Griggs, Christopher. (2003). Military Justice Review: Discussion Paper and Options Papers. NZDF: Wellington, NZ.

Griggs, Christopher. (2006). 'A New Military Justice System for New Zealand'. The Military Law and Law of War Review (3-4): 287-327.

Hamilton, Bill (Treaty Section, HRC). (2009). Personal communication (email dated 25 June 2009).

Hansard Debates. (2007a). Armed Forces Law Reform Bill - First Reading 15 March 2007. Vol. 637: 8063.

Hansard Debates. (2007b). Armed Forces Law Reform Bill - Second Reading 9 October 2007. Vol. 642: 12165.

Hansard Debates. (2007c). Armed Forces Discipline Amendment Bill (No. 2), Court Martial Appeals Amendment Bill, Defence Amendment Bill (No. 3), Court Martial Bill- 
Third Reading 24 October 2009.

Hay, J.C. (for Secretary of Justice). (1995). Letter sent to Commissioner of Police entitled 'Baigent's Case: Papers for Cabinet Strategy Committee'. Dated 27 April 1995 (received as a result of Official Information Act request from the Ministry of Justice on 7 August 2008).

Henkin, Louis. (1995). 'Human Rights and State Sovereignty'. Ga. J. Int'l \& Comp. L 25: $31-45$.

Henn, M, Weinstein, M and Foard, N. (2009). A Critical Introduction to Social Research (2nd Edn). Sage Publications Ltd: Thousand Oaks, CA, USA.

Hepple, Bob. (2006). 'Positive Obligations to Ensure Equality'. Interights Bulletin 15: 114-1 16.

Herbert, Ruth. (2009). 'Implementing Government Strategies for Complex Social Problems'. Policy Quarterly 5(3): 50-57.

High and Complex Needs Intersectoral Unit. (2007). Better at Working Together: Interagency Collaboration. Part I - Literature Review; Part II - Advice on Good Practice; Part III - Self-assessment Tool and Principles for Collaboration. Wellington, NZ.

Hook, Gordon. (2002). The Constitutional Status of Military Tribunals: Paradigm Lost, Paradigm Regained. A Critical Analysis of New Zealand's Military Justice in the Light of International Trends. Doctor of Philosophy in Law Thesis, Victoria University: Wellington, NZ.

Human Rights Commission. (1998). Consistency 2000: Report to the Minister of Justice Pursuant to Section 5(1)(k) of the Human Rights Act 1993. HRC: Wellington, NZ.

Human Rights Commission. (2003). Human Rights and the Treaty of Waitangi: Te Mana $i$ Waitangi. HRC: Wellington, NZ.

Human Rights Commission. (2004a). Human Rights in New Zealand Today. HRC: Auckland, NZ.

Human Rights Commission. (2004b). Right to Education: He Tapapa Mauauranga - A 
Discussion Document. HRC: Auckland, NZ.

Human Rights Commission. (2005a). New Zealand Action Plan for Human Rights 2005-2010 (Mana ki te Tangata). HRC: Wellington, NZ.

Human Rights Commission. (2005b). Submission to the Constitutional Arrangements Committee (April 2005). HRC: Wellington, NZ.

Human Rights Commission. (2008a). The Human Rights Approach. HRC: Wellington, NZ.

Human Rights Commission. (2008b). Report for New Zealand's Universal Periodic Review. HRC: Wellington, NZ.

Human Rights Commission. (2008c). Media Release: Tribunal Finds ACC Inconsistent With Bill of Rights (19 May 2008). (Accessed at www.hrc.co.nz on 1 June 2009).

Human Rights Commission. (2008d). Project Plan 08/09. (Internal document supplied by Susan Biggs, Manager, Strategic Policy Team, HRC on 10 October 2008 and received as a result of an Official Information Act request).

Human Rights Commission. (2009a). Letter to Prime Minister John Key from Rosslyn Noonan, Chief Human Rights Commissioner and Joris de Bres, Race Relations Commissioner on UN Declaration on the Rights of Indigenous Peoples (6 April 2009). HRC: Wellington, NZ.

Human Rights Commission. (2009b). Draft Scoping Paper: Human Rights Dimensions of the Treaty of Waitangi. HRC: Wellington, NZ.

Human Rights Commission. (2009c). Crown-Māori Relationship Instruments. (Accessed at www.hrc.co.nz on 31 August 2009).

Human Rights Commission. (2009d). Declaration on the Rights of Indigenous Peoples and the Treaty of Waitangi (draft). HRC: Wellington, NZ.

Human Rights Commission. (2010). Te Mana i Waitangi: Human Rights and the Treaty of Waitangi (draft). HRC: Wellington, NZ.

Huscroft, Grant and Rishworth, Paul (Eds). (1995). Rights and Freedoms: The New Zealand Bill of Rights Act 1990 and the Human Rights Act 1990. Brookers: Wellington, 
NZ.

International Commission of Jurists. (2006). The Limburg Principles on the Implementation of the International Covenant on Economic, Social and Cultural Rights. ICJ: Maastricht, Holland.

James, Stephen. (2009). 'A Right to Welfare'. In Celebrating Human Rights: Sixty Years of the Universal Declaration: Proceedings of the Wellington Conference. R. Alley (Ed). NZ Human Rights Commission and NZ Institute of International Affairs: Wellington, NZ.

Johnson, Christine (Principal Human Resources Adviser, NZDF). (2010). Personal communication (email dated 1 February 2010).

Joseph, Philip. (2007). Constitutional and Administrative Law in New Zealand (3rd Edn). Thomson Brookers: Wellington, NZ.

Keegan, Rachel. (2004). 'The Growing Burden of Student Loans'. New Zealand Journal of Teachers' Work 1: 104.

Keith, Ken. (2004). 'Sovereignty at the Beginning of the $21^{\text {st }}$ Century: Fundamental or Outmoded?' The Cambridge Law Journal 63(3): 581-604.

Kerr, DB (Chief Legal Advisor, NZ Police). (1994). Letter to the Solicitor-General entitled 'Baigent and Bradford v Attorney-General - Proposed Privy Council Appeal' with Addendum. Dated 25 November 1994 (received as result of Official Information Act request from the Ministry of Justice on 7 August 2008).

Kerr, DB (Chief Legal Advisor, NZ Police). (1995). Letter to the Secretary for Justice entitled 'Draft Cabinet Papers on Options Following Court of Appeal Decisions in Baigent and AUWRC'. Dated 6 April 1995 (received as result of Official Information Act request from the Ministry of Justice on 7 August 2008).

Kirby, Michael. (1997). 'Domestic Implementation of International Human Rights Norms'. Paper given at Conference on Implementing International Human Rights (6 December 1997), ANU Faculty of Law, Canberra, Australia.

Kirby, Michael. (2005). 'Judicial Activism? A Riposte to the Counter-Reformation'. 
Otago Law Review 11(1): 1-16.

Kobin, Stephen. (1997). 'The Architecture of Globalization: State Sovereignty in a Networked Global Economy'. In Governments, Globalization and International Business. J Dunning (Ed). OUP: Oxford, UK.

Ladley, A and Williams, J. (2007). 'Electoral Education' in PNG: A Survey of Existing Literature and Reports. Institute of Policy Studies, Victoria University: Wellington, NZ.

Lauren, Paul. (1997). New Zealand's Role in the Evolution of International Human Rights. Presentation delivered in Wellington, NZ in December 1997.

Lauren, Paul. (1998). 'Setting the Stage: New Zealand and the Creation of the Universal Declaration of Human Rights'. In 50 th Anniversary: Universal Declaration of Human Rights. Council for International Development and Amnesty International (NZ): Wellington, NZ.

Lauren, Paul. (2003). The Evolution of International Human Rights. University of Pennsylvania Press: Philadelphia, USA.

Leiser, Burton and Campbell, Tom. (2001). Human Rights in Philosophy and Practice. Ashgate: USA.

Lewis-Beck, M., Bryman, A. and Futing Lioa, T. (2004). The Sage Encyclopedia of Social Science Research Methods. Sage Publications: Thousand Oaks, CA, USA.

Liebenberg, Sandra. (2001). 'The Protection of Economic and Social Rights in Domestic Legal Systems'. In Economic, Social and Cultural Rights (2nd Edn). A. Eide, C. Krause and A. Rosas (Eds). Kluwer Law International: The Hague, The Netherlands.

Liebenberg, Sandra. (2006). 'Adjudicating the Positive Duties Imposed by Economic, Social and Cultural Rights. Interights Bulletin 15(3): 109-113.

Local Government NZ. (2007). Co-Management: Case Studies Involving Local Authorities and Māori. LGNZ: Wellington, NZ.

Loose, Hine-Wai (UN Human Rights and Commonwealth Division, MFAT). (2009b). Personal communication (email dated 6 November 2009). 
Luttrell, Wendy (Ed). (2010). Qualitative Educational Research: Readings in Reflexive Methodology and Transformative Practice. Routledge: New York, NY, USA.

Mabry, Linda. (2008). 'Case Study in Social Research'. In The Sage Handbook of Social Research Methods. P Alasuutari, Leonard Bickman and Julia Brannen (Eds). Sage Publications: London, UK.

Marshall, Christopher. (2001). Crowned with Glory and Honor: Human Rights in the Biblical Tradition. Pandora Press: Telford, PA, USA.

McCullogh, Jackie (Legal Adviser, NZ Police). (2009). Personal communication (letter dated 13 March 2009 received as a result of an Official Information Act request).

McMillan, Neale. (2003). 'Student Loans Face Stern Examination'. MG Business: Mercantile Gazette 127: 4-7.

Ministry of Education. (2007). The New Zealand Curriculum (accessed at www.rightsined.org.nz on 31 August 2009). MoE: Wellington, NZ.

Ministry of External Relations and Trade. (1990). Human Rights in New Zealand: The Presentation of New Zealand's Second Periodic Report to the Human Rights Committee Under the International Covenant on Civil and Political Rights (Information Bulletin 30). MFAT, Wellington, NZ.

Ministry of Foreign Affairs and Trade. (1994). Human Rights in New Zealand: Initial Report to the United Nations Committee on Economic, Social and Cultural Rights (Information Bulletin 49). MFAT: Wellington, NZ.

Ministry of Foreign Affairs and Trade. (1995). Human Rights in New Zealand: New Zealand's Third Report to the United Nations Human Rights Committee on Implementation of the International Covenant on Civil and Political Rights (Information Bulletin 54). MFAT: Wellington, NZ.

Ministry of Foreign Affairs and Trade. (2002). Fourth Periodic Report of New Zealand on the Implementation of the International Covenant on Economic, Social and Cultural Rights (CCPR/CO/75). MFAT: Wellington, NZ.

Ministry of Foreign Affairs and Trade. (2006a). Core Document Forming Part of the 
Reports of States Parties: New Zealand (HRI/CORE/NZL/2006). MFAT: Wellington, NZ.

Ministry of Foreign Affairs and Trade. (2006b). Statement by Clive Pearson, Representative of New Zealand, on Behalf of Australia, New Zealand and the United States, on the Declaration on the Rights of Indigenous Peoples, 17 May 2006. MFAT: Wellington, NZ. (Accessed at www.mfat.govt.nz on 22 May 2009).

Ministry of Foreign Affairs and Trade. (2006c). Statement by HE Ambassador Rosemary Banks on Behalf of Australia, New Zealand and the United States, Monday 16 October 2006. MFAT: Wellington, NZ. (Accessed at www.mfat.govt.nz on 22 May 2009.)

Ministry of Foreign Affairs and Trade. (2007). International Covenant on Civil and Political Rights: Fifth Periodic Report of Government of New Zealand (CCPR/C/NZL/2007). MFAT: Wellington, NZ.

Ministry of Foreign Affairs and Trade. (2008). New Zealand Handbook on International Human Rights. MFAT: Wellington, NZ.

Ministry of Justice. (2000a). Re-evaluation of the Human Rights Protections in New Zealand: Report for the Associate Minister of Justice and Attorney-General Hon. Margaret Wilson. MoJ: Wellington, NZ.

Ministry of Justice. (2000b). The Human Rights Act 1993: Guidelines for Government Policy Advisers. MoJ: Wellington, NZ.

Ministry of Justice. (2001). Re-evaluation of Human Rights Protections in New Zealand: Summary of Public Submissions. MoJ: Wellington, NZ.

Ministry of Justice. (2002). The Non-Discrimination Standards for Government. MoJ: Wellington, NZ.

Ministry of Justice. (2004). Guidelines on the New Zealand Bill of Rights Act 1990: A Guide to the Rights and Freedoms in the Bill of Rights Act for the Public Sector. MoJ: Wellington, NZ.

Ministry of Social Development. (2008). Children and Young People: Indicators of 
Wellbeing in New Zealand (Summary Document). MSD: Wellington, NZ.

New Zealand Constitutional Arrangements Committee. (2005). Inquiry to Review New Zealand's Existing Constitutional Arrangements: Report of the Constitutional Arrangements Committee to Forty-seventh Parliament (August 2005). NZ Parliament: Wellington, NZ.

New Zealand Defence Force. (2009a). 'Judges Sworn in to New Military Judicial System'. NZDF News Media Release 10 July 2009. NZDF: Wellington, NZ.

New Zealand Defence Force. (2009b). 'Changes to Military Justice System'. (Accessed on www.nzdf.mil.co.nz on 19 October 2009).

New Zealand House of Representatives. (2005). Inquiry into the Role of International Human Rights in Foreign Policy: Report of the Foreign Affairs, Defence and Trade Committee. NZ Parliament: Wellington, NZ.

New Zealand Law Commission. (1996). A New Zealand Guide to International Law and its Sources. NZLC: Wellington, NZ.

New Zealand Law Commission. (1997). Crown Liability and Judicial Immunity: A Response to Baigent's Case and Harvey $v$ Derrick (NZLC Report 37). NZLC: Wellington, NZ.

New Zealand Law Commission. (2006). Converging Currents: Custom and Human Rights in the Pacific. NZLC: Wellington, NZ.

New Zealand Law Review. (2009). 'Special Issue: Human Rights in the Pacific'. NZLR 40(1): 1-417.

New Zealand Parliament. (2009). Order Paper and Questions: Questions for Oral Answer 31 March 2009. NZ Parliament: Wellington, NZ.

New Zealand Police. (1990). 'Legal: New Zealand Bill of Rights Act'. NZ Police Gazette (36): 248-252.

New Zealand Police. (1991). The Bulletin (353): July.

New Zealand Police. (1992a). New Law: Issue 6. 
New Zealand Police. (1992b). New Law: Issue 7.

New Zealand Police. (1995). 'Index: GIs, Law Notes \& Policy'. In Ten-One (107): December.

New Zealand Police. (2009). Manual of Best Practice on the NZ Bill of Rights. NZ Police Intranet: Wellington, NZ.

Noonan, Rosslyn. (2008). Celebrating 60 Years of the Universal Declaration of Human Rights: Reporting Progress on New Zealand Human Rights. Paper presented at 'Celebrating 60 Years of the UDHR' conference held at Victoria University Law School, 9 and 10 December 2008. HRC: Wellington, NZ.

Noonan, Rosslyn. (2009). Speaker at session on 'International Accountability for New Zealand's Human Rights and Race Relations, Human Rights Treaties and Domestic Policy and Practice'. As part of the NZ Diversity Forum 09 held on 23-24 August 2009 hosted by the HRC at the Victoria University Law Faculty, Wellington, NZ.

Oberleitner, Gerd. (2007). Global Human Rights Institutions: Between Remedy and Ritual. Polity Press: Cambridge, UK.

O’Brien, John. (2001). International Law. Cavendish Publishing Ltd: London, UK.

Office of the High Commissioner for Human Rights. (2003). Human Rights in the Administration of Justice: A Manual on Human Rights for Judges, Prosecutors and Lawyers (Professional Training Series No. 9). OHCHR: New York, USA.

Office of the High Commissioner for Human Rights. (2007). Good Governance Practices for the Protection of Human Rights. OHCHR: New York, USA.

Office of the Minister of Justice. (1995a). Memorandum for Cabinet Strategy Committee. Baigent's Case: Options for Government. Dated 24 May 1995 (received as a result of Official Information Act request from the Ministry of Justice on 7 August 2008).

Office of the Minister of Justice. (1995b). Memorandum for Cabinet Strategy Committee. Baigent's Case: Summary of Decision and Likely Effects with Schedule. Dated 24 May 1995 (received as a result of Official Information Act request from the 
Ministry of Justice on 7 August 2008).

Office of the Minister of Justice. (1995c). Memorandum for Cabinet Strategy Committee - Baigent's Case: Form of Possible Amendments. Dated 16 August 1995 (received as a result of Official Information Act request from the Ministry of Justice on 7 August 2008).

O'Flaherty, Michael. (2006). 'The Concluding Observations of UN Human Rights Treaty Bodies'. Human Rights Law Review 2006: 27-52.

Organisation for Economic Co-operation and Development. (2007). Fragile States: Policy Commitment and Principles for Good International Engagement in Fragile States and Situations. OECD: Paris, France.

Palmer, Geoffrey. (1979). Unbridled Power: An Interpretation of New Zealand's Constitution and Government. OUP: Wellington, NZ.

Palmer, Geoffrey. (2006). What is Distinctive About New Zealand Law and the New Zealand Way of Doing Law - Innovation in New Zealand Statute Law. Paper delivered to celebrate the $20^{\text {th }}$ anniversary of the New Zealand Law Commission on 25 August 2006, Wellington, NZ.

Palmer, Geoffrey. (2007). Government and Advice: Reflections Upon the Wellington Policy-Making Culture. Paper presented at 'From Professing to Advising to Judging Conference' held in honour of Sir Kenneth Keith at Victoria University Law School, Wellington, NZ on 24 August 2007.

Palmer, Matthew. (2006). Thinking about Law and Policy: Lessons for Lawyers. Paper written as a result of seminars to the Law Commission and the Crown Law Office on 23 and 27 November 2006, Wellington, NZ.

Palmer, Matthew. (2008). The Treaty of Waitangi in New Zealand's Law and Constitution. Victoria University Press: Wellington, NZ.

Palombella, G. and Walker, N. (2009). Relocating the Rule of Law. Hart Publishing: Oregon, USA.

Parsons, Wayne. (1995). Public Policy: An Introduction to the Theory and Practice of 
Policy Analysis. Edward Elgar Publishing Ltd: Aldershot, UK.

Payne, Caroline and Sill, Kaitlyn. (2008). 'Importing Human Rights Through Domestic Constitutional Protections: Establishing the Relationship Between the International Human Rights Regime and Domestic Institutions'. Paper presented for presentation at the annual meeting of the International Studies Association in San Francisco, CA, USA on 26-29 March 2008.

Pohjolainen, Anna Elina. (2006). The Evolution of National Human Rights Institutions. The Danish Institute for Human Rights: Copenhagen, Denmark.

Power, Simon (Minister of Justice). (2009). Speaker at session on 'International Accountability for New Zealand's Human Rights and Race Relations, Human Rights Treaties and Domestic Policy and Practice'. As part of the NZ Diversity Forum 09 held on 23-24 August 2009 hosted by the HRC at the Victoria University Law Faculty, Wellington, NZ.

Punch, Keith. (2005). Introduction to Social Research: Quantitative and Qualitative Approaches. Sage Publications: Thousand Oaks, USA.

Quinn Patton, Michael. (2002). Qualitative Research \& Evaluation Methods (3rd Edn). Sage Publications: Thousand Oaks, USA.

Renshaw, Catherine, Byrnes, Andrew and Durbach, Andrea. (2009). 'Regional and National Human Rights Protection: Creating a New Model in the Pacific'. Paper presented at ANZSIL Conference (2-4 July 2009) held at Victoria University Law School, Wellington, NZ.

Research Policy Group. (2010). VUW Human Ethics Policy. Accessed at http://policy.vuw.ac.nz/Amphora! policy.vuw.ac.nz POLICY 000000000744.pdf on 22 August 2010.

Rishworth, Paul. (2003). The New Zealand Bill of Rights. OUP: Auckland, NZ.

Rishworth, Paul. (2004). "The Inevitability of Judicial Review Under "Interpretive" Bills of Rights'. SCLR 23: 233, 266. 
Robertson, J.B. (Ed). (2010). Adams on Criminal Law. Thomson: Wellington, NZ.

Rosas, Allan and Scheinin, Martin. (2001). 'Implementation Mechanisms and Remedies'. In Economic, Social and Cultural Rights (2nd Edn). A. Eide, C. Krause and A. Rosas (Eds). Kluwer Law International: The Hague, The Netherlands.

Rose, E., Huakau, J., Sweetsur, P. and Casswell, S. (2005). Social Values: A Report from the New Zealand Values Study 2005. Massey University, SHORE, Wellington Clinical School of Medicine: Wellington, NZ.

Royal Institute of International Affairs. (1947). United Nations Documents 1941-1945. Royal Institute: London, UK.

Ryan, B., Gill, D., Eppel, E. and Lips, M. (2008). 'Managing for Joint Outcomes: Connecting up the Horizontal and the Vertical'. Policy Quarterly 4(3): 14-21.

Saito, Natsu Taylor. (1996). 'Beyond Civil Rights: Considering "Third Generation" International Human Rights Law in the United States'. The University of Miami InterAmerican Law Review 28(2): 388-398.

Sajo, Andras (Ed). (2004). Human Rights with Modesty: The Problem of Universalism. Martinus Nijoff Publishers: Leiden, The Netherlands.

Scheinin, Martin. (2001). 'Economic and Social Rights as Legal Rights'. In Economic, Social and Cultural Rights (2nd Edn). A. Eide, C. Krause and A. Rosas (Eds). Kluwer Law International: The Hague, The Netherlands.

Seidensticker, Frauke Lisa. (2005). Examination of State Reporting by Human Rights Treaty Bodies: An Example of Follow-up at the National Level by National Human Rights Institutions. German Institute for Human Rights: Berlin, Germany.

Shacklock, G. and Smyth, J. (1998). Being Reflexive in Critical Educational and Social Research. Falmer Press: London, UK.

Shaw, Malcolm. (2003). International Law (5 ${ }^{\text {th }}$ Edn). CUP: Cambridge, UK.

Shaw, Richard and Eichbaum, Chris. (2005). Public Policy in New Zealand: Institutions, Processes and Outcomes. Pearson Education NZ: Auckland, NZ. 
Shelton, Dinah. (1991). 'Human Rights, Environmental Rights, and the Right to Environment'. Stanford Journal of International Law 28: 103.

Simester, A.P. and Brookbanks, W.J. (2002). Principles of Criminal Law. ThomsonBrookers: Wellington, NZ.

Simpson, Ced. (2009). 'Human Rights and Education: A New Zealand Initiative'. In Celebrating Human Rights: Sixty Years of the Universal Declaration: Proceedings of the Wellington Conference. R. Alley (Ed). NZ Human Rights Commission and NZ Institute of International Affairs: Wellington, NZ.

Spackman, Scott (Acting Chief Legal Advisor, NZ Police). (2008). Personal communication (letter dated 7 October 2008 as a response to an Official Information Act request).

Sparrow, Malcolm. (2000). The Regulatory Craft: Controlling Risks, Solving Problems and Managing Compliance. Brookings Institution Press: Washington DC, USA.

Stake, Robert. (2005). 'Qualitative Case Studies'. In The Sage Handbook of Qualitative Research. N Denzin and Y Lincoln (Eds). Sage Publications: Thousand Oaks, CA, USA.

State Services Commission. (2004). Getting Better at Managing for Shared Outcomes: A Resource for Agency Leaders. (Accessed at www.ssc.govt.nz on 31 January 2009).

State Services Commission. (2008). Factors for Successful Coordination - Helping State Agencies Coordinate Effectively. (Accessed at www.ssc.govt.nz on 31 January 2009).

Steiner, H. (1999). 'Do Human Rights Require a Particular Form of Democracy?' In Democracy, the Rule of Law and Islam. Adel Omar Sherif and Eugene Contran (Eds). Kluwer Law International Press: London, UK.

Steiner, H. (2006). 'International Protection of Human Rights'. In International Law (2nd Edn). Malcolm Evans (Ed). OUP: Oxford, UK.

Steiner, H, Alston, P and Goodman, R. (2008). International Human Rights in Context: 
Law, Politics, Morals. OUP: Oxford, UK.

Stewart, Blair. (1995). 'Lawmakers Under Surveillance - The Privacy Commissioner's Legislative Monitoring Role'. Brooker's Human Rights Law and Practice (1): 36-42.

Templeton, Malcolm. (1995). 'New Zealand at San Francisco'. In New Zealand as an International Citizen: Fifty Years of United Nations Membership. Malcolm Templeton (Ed). MFAT: Wellington, NZ.

Te Puni Kokiri, Ministry of Justice and Crown Law Office. (2006). Crown-Māori Relationship Instruments: Guidelines and Advice for Government and State Sector Agencies. TPK: Wellington, NZ.

Thomas, E.W. (2005). 'So-called "Judicial Activism" and the Ascendancy of Judicial Constraints'. New Zealand Universities Law Review 21(4): 685-710.

Thompson, E.P. (1985). Whigs and Hunters: The Origins of the Black Act. Penguin: Harmondsworth, UK.

Tushnet, Mark. (2008). Weak Courts, Strong Rights: Judicial Review and Social Welfare Rights in Comparative Constitutional Law. Princeton University Press: NJ, USA.

UK Parliament. (2004). Joint Committee on Human Rights Twenty-first Report: The International Covenant on Economic, Social and Cultural Rights (2 November 2004). UK Parliament: London, UK.

United Nations. (2008). Compilation of Guidelines on the Form and Content of Reports to be Submitted by States Parties to the International Human Rights Treaties (HRI/GEN/2/Rev.5) 29 May 2008. UN: Geneva, Switzerland.

United Nations. (2009). UN Committee Against Torture Concluding Observations of the Committee Against Torture: New Zealand's Fifth Periodic Report (CAT/C/NLZ/5) 14 May 2009. UN: Geneva, Switzerland.

United Nations Committee on Economic, Social and Cultural Rights. (1998). General Comment No. 9: The Domestic Application of the Covenant E/C/12/1998/24. UN: New 
York, USA.

United Nations Economic and Social Council. (2003). Report of the UN High Commissioner for Human Rights and Follow-up to the World Conference on Human Rights (E.CN.4/2003/14). UN: Geneva, Switzerland.

United Nations General Assembly. (1998). Fourteenth Report on Reservations to Treaties: Report of the Special Rapporteur (Document A/CN.4/614 and Addendum). UN: Geneva, Switzerland.

United Nations General Assembly. (2004). Press Release GA/10317 of 10 December 2004: General Assembly Proclaims World Programme for Human Rights. UN: Geneva, Switzerland.

United Nations General Assembly. (2009a). Human Rights Council: National Report Submitted in Accordance with Paragraph 15 (A) of the Annex to Human Rights Council Resolution 5/1 - New Zealand (A/HRC/WG.6/5/NZL/1) 9 April 2009. UN: Geneva, Switzerland.

United Nations General Assembly. (2009b). Human Rights Council: Draft Report of the Working Group on the Universal Periodic Review - New Zealand (A/HRC/WG.6/5/L.7) 11 May 2009. UN: Geneva, Switzerland.

United Nations General Assembly. (2009c). Human Rights Council: Universal Periodic Review: Report of the Working Group on the Universal Periodic Review - New Zealand. Addendum: Views on Conclusions and/or Recommendations, Voluntary Commitments and Replies Presented by the State under Review (A/HRC/12/8/Add.I) 7 July 2009. UN: Geneva, Switzerland.

USA Government. (1998). Executive Order 13107: Implementation of Human Rights Treaties (10 December 1998). Office of the Press Secretary, The White House: Washington, UK.

Vasak, Karel (Ed). (1982). The International Dimensions of Human Rights (Vol 1: Revised and edited for the English edition by Philip Alston). Greenwood Press: Westport, CT, USA.

Victoria Human Rights Committee. (2005). Rights, Responsibilities and Respect: The 
Report of the Human Rights Committee. State of Victoria: Melbourne, Australia.

Victoria University Human Rights Programme. (2003 ongoing). Human Rights Research. Paul Morris and Helen Greatrex (Eds). Victoria University: Wellington, NZ (can be accessed as online journal at www.victoria.ac.nz/nzcpl/).

Waldron, Jeremy. (2005). 'Compared to What? Judicial Activism and New Zealand's Parliament'. NZLJ 441-445.

Waters, Melissa. (2007). 'Creeping Monism: The Judicial Trend Toward Interpretive Incorporation of Human Rights Treaties'. Columbia Law Review (107): 628.

Weiss, Edith Brown. (1990). 'Our Rights and Obligations to Future Generations for the Environment'. The American Journal of International Law 84(1): 198-207.

White, Michael (Legal and Policy Advisor, HRC). (2009). Personal communication (email dated 20 August 2009).

Wild, Richard. (1968). 'Human Rights in Retrospect'. In Essays on Human Rights. Ken Keith (Ed). Sweet \& Maxwell: Wellington, NZ.

Wilson, Mike (Superintendent and National Training Manager, NZ Police). (2009). Personal communication (email dated 27 November 2009). 